\begin{abstract}
VIBART, RONALDO. Performance of Lactating Dairy Cows Fed Varying Levels of Total Mixed Ration and Pasture. (Under the direction of Dr. Vivek Fellner.)
\end{abstract}

Limited research is available that evaluates animal productivity from increasing levels of pasture supplementation to dairy confinement-type diets. Two 8-week field studies (fall of 2004, F2004; and spring of 2005, F2005) and an in vitro continuous culture study were conducted to examine animal performance under different combinations of total mixed ration (TMR) feeding and high-quality pasture grazing. Such feeding systems are increasingly referred to as a partial mixed ration (PMR). Cows were assigned to either an all-TMR diet (100T, no access to pasture) or one of the following three PMR diets: 1) 85\% TMR-restricted (85T) 2) 70\% TMR-restricted (70T) and 3) 55\% TMR-restricted (55T). Actual diets during the fall trial became 59\% TMR and 41\% pasture, 68\% TMR and 32\% pasture, and 79\% TMR and $21 \%$ pasture instead of the formulated 55T, 70T, and 85T, respectively. The corresponding actual diets during the spring trial became 65\% TMR and 35\% pasture, 79\% TMR and 21\% pasture, and 89\% TMR and 11\%, respectively. Cows on the PMR diets had access to pasture (annual ryegrass) and grazed as a single group for $7 \mathrm{~h} / \mathrm{d}$ between a.m. and p.m. milkings. In F2004, the TMR feeding system maximized total dry matter intake (DMI) and milk production, but 4\% fat-corrected milk (FCM), milk fat yield and protein yield did not differ among diets. In S2005, FCM was greatest for treatments 85T and 100T, and lowest for treatment 70T, with 55T yielding an intermediate value. Milk fat and protein yields were greatest for treatments $85 \mathrm{~T}$ and $100 \mathrm{~T}$ compared with those diets that included the greatest amount of pasture. Greatest DM intake from pasture was associated with the greatest concentration of conjugated linoleic acids (CLA, a group of fatty acids with potent cancer- 
fighting properties) in milk. Also, concentrations of saturated fatty acids in milk fat were greatest for cows consuming TMR. Gross feed efficiencies (kg FCM per kg DMI) were similar for all diets in F2004, but in S2005, cows consuming PMR exhibited enhanced gross feed efficiencies compared to cows consuming TMR exclusively.

Continuous culture fermentation allowed for the assessment of ruminal fermentation patterns, intermediates, and end products of fermentation to better understand the production responses obtained from the two field trials. Ruminal variables examined included ruminal culture $\mathrm{pH}$, methane $\left(\mathbf{C H}_{4}\right)$ production, ammonia nitrogen $\left(\mathbf{N H}_{3}-\mathbf{N}\right)$ concentration, volatile fatty acid (VFA) production, and microbial biomass production. Increasing the amount of forage added to the fermentors altered the molar proportions and daily production of VFA. Treatment 55T tended $(P=0.08)$ to yield the greatest amounts of total VFA $(108.0 \mathrm{mmol} / \mathrm{d})$, followed by treatment $85 \mathrm{~T}(98.7 \mathrm{mmol} / \mathrm{d})$. Methane production was greatest $(P<0.05)$ for the all-TMR diet $(42.5 \mathrm{mmol} / \mathrm{d})$ and lowest for 70T $(16.6 \mathrm{mmol} / \mathrm{d})$. Reduced $(P<0.05)$ apparent and true DM degradabilities were reported for the treatments that exhibited the lowest $\mathrm{pH}$ values (5.65 and 5.68 for $70 \mathrm{~T}$ and 100T, respectively). Increasing the amount of forage offered to continuous cultures resulted in an increase $(P<0.05)$ in microbial DM flow and decreased $\mathrm{CH}_{4}$ production. Although ruminal $\mathrm{NH}_{3}-\mathrm{N}$ concentration was similar for all diets, increasing the amount of forage resulted in improved $\mathrm{N}$ capture by ruminal microorganisms. These studies suggest that in PMR feeding systems such as the ones tested pasture can be as high as $41 \%$ without affecting overall lactation performance when compared to an all-TMR ration. 


\title{
PERFORMANCE OF LACTATING DAIRY COWS FED VARYING LEVELS OF \\ TOTAL MIXED RATION AND PASTURE
}

\author{
by \\ RONALDO EDUARDO VIBART
}
A dissertation submitted to the Graduate Faculty of
North Carolina State University
In partial fulfillment of the
Requirements for the degree of
Doctor of Philosophy

Animal Science and Poultry Science

Raleigh, North Carolina

2006

Approved by:

Dr. Vivek Fellner

Chair of Advisory Committee

Dr. Gerald B. Huntington

Member of Advisory Committee
Dr. Joseph C. Burns

Member of Advisory Committee

Dr. Steven P. Washburn

Member of Advisory Committee 


\section{DEDICATION}

To Dick and Hazel, and to Celina and Martin, with love 


\section{BIOGRAPHY}

Ronnie pursued a Bachelor degree from the National University of Mar del Plata in Balcarce, Province of Buenos Aires, Argentina. He graduated in 1988 with a degree in Agricultural Engineering. Since then he has worked on several farm operations and processing plants in different management, extension, and consulting positions; along with the rewarding experience of having taught dairy management skills as a dairy instructor in a farming school near Tandil, his home place.

A Rotary scholarship allowed him to visit the US for the first time in 1993, touring the State of Wisconsin for five weeks and getting in touch with America's finest dairy tradition. Previously, a four-month working tour to the North Island of New Zealand allowed him to refine his rugby skills and closely interact with the most efficient pasture-based dairy agriculture in the world.

After a six-month period in Charlotte, NC, where Celina (his wife and best friend) was fulfilling a Fulbright teaching exchange, he entered Graduate School as a teaching assistant at North Carolina State University. He got his Master of Science degree in the fall of 2003 ('Continuous Culture Fermentation of Wild-Type, Endophyte-Infected, EndophyteFree, and Non-Toxic Endophyte-Infected Tall Fescue Supplemented at Four Energy Levels'). Ronnie is currently a research assistant under Dr. Vivek Fellner working towards

obtaining his Ph.D. degree in Animal Science. He is a member of the American Society of Dairy Science and the proud father of Martin B. Vibart (born May 24, 2004), the most wonderful creature on earth. 


\section{ACKNOWLEDGEMENTS}

I would like to express my deepest gratitude to Dr. Vivek Fellner for his guidance, patience, support, and kindness. He has taught me the true meaning of friendship throughout all these years and stood by me all the way. I would also like to thank Dr. Joe Burns, Dr. Gerald Huntington, and Dr. Steve Washburn for their generous guidance and patience. My gratitude is also extended to Sarah Jo McLeod for her invaluable contribution assisting with sample collection, sample analyses, and overall infinite patience and kindness, and to Ellen Leonard for her contribution in sample analyses, and patience. Without all of your advice and support, this dissertation would not have been possible. Huge thanks too to Pete Thompson, Justin Garrett, and Dr. Jim Green for your time, enthusiasm, and efforts in making the forage data collection possible, along with Weston McCorkle, Wayne McLamb, and the entire LWDEU crew.

I would also like to thank Marian Correll and Mebane Galloway for their kindness and infinite patience. Also, to my colleagues and friends Ziggy, Diego, Carlos, Leo, and Tim; and to my soccer mates Hugo, Ivo, Claudiney, Eric, and Gonzalo, to all of you my deepest gratitude. Most of all, I would like to thank my wife Celina, who supported my efforts with unconditional love, patience, and pragmatic advice, and my son Martin, both of whom make me a better person. 


\section{TABLE OF CONTENTS}

Page

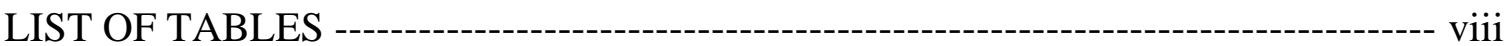

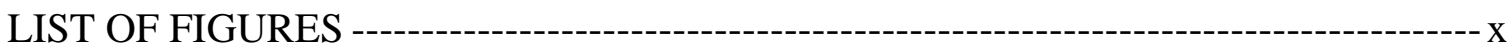

\section{CHAPTER 1}

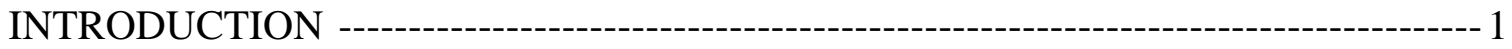

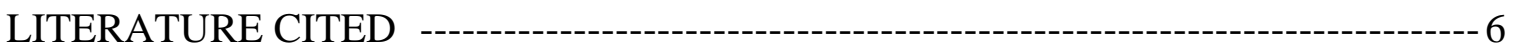

\section{CHAPTER 2}

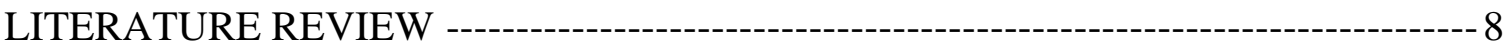

THE USE OF PASTURE IN HIGH-PRODUCING DAIRY COW FEEDING

SYSTEMS IN SOUTHEASTERN U.S.----_- 9

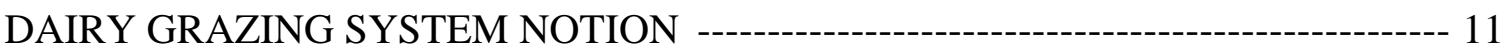

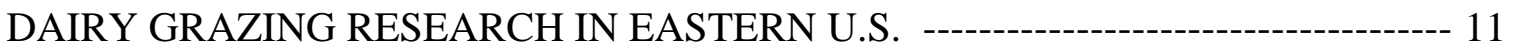

Transitioning from dairy grazing to confinement feeding systems ------------------------ 12

Renewed interest in pasture-based feeding systems ------------------------------------- 15

PERFORMANCE AND DRY MATTER INTAKE OF GRAZING COWS

Performance and dry matter intake of grazing cows on pasture only diets ---------------- 18

Performance and dry matter intake of cows fed pasture-based diets ----------------------- 21

Performance and dry matter intake of cows fed pasture or pasture-based diets vs. total

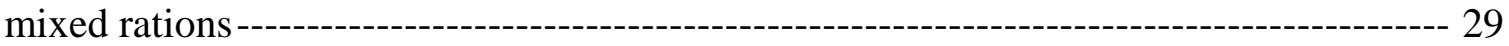

ESTIMATING DRY MATTER INTAKE OF GRAZING COWS --------------------- 32

RUMINAL ENVIRONMENT AND DIGESTION OF COWS FED PASTURE OR

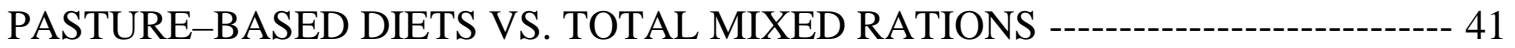

RUMINAL LIPID METABOLISM AND MILK LONG-CHAIN FATTY ACID COMPOSITION OF GRAZING COWS

Overview of Ruminal lipid metabolism ----------------------------------------------- 48

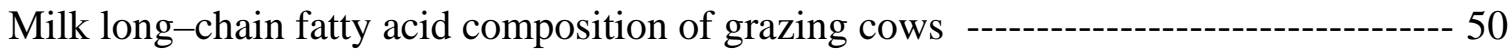

Milk conjugated linoleic acid and other selected fatty acid concentrations of grazing vs.

nongrazing dairy cows ------------------------------------------------------------- 52 
Lipid content and long-chain fatty acids of fresh forages ----------------------------------- 59

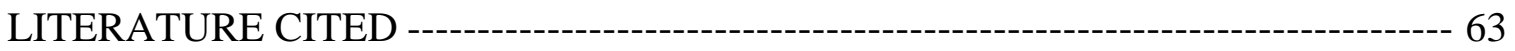

\section{CHAPTER 3}

PERFORMANCE OF LACTATING DAIRY COWS FED VARYING LEVELS OF TOTAL MIXED RATION AND PASTURE

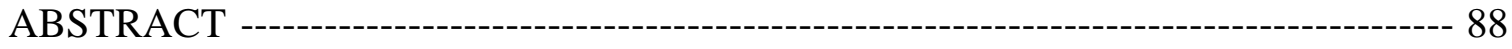

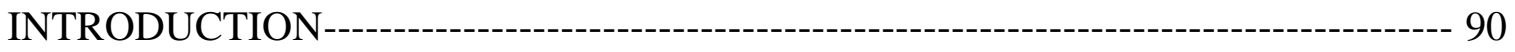

MATERIALS AND METHODS

Experiment 1

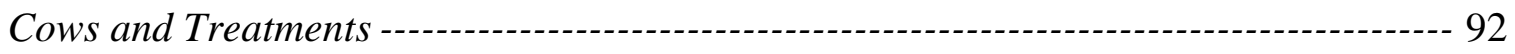

Confinement and Pasture Feeding Management---------------------------------------------- 93

Pasture Intake Measurements -------------------------------------------------------- 95

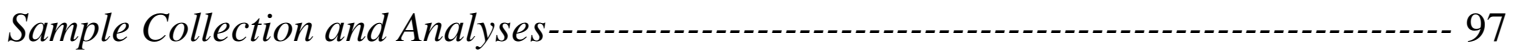

Experiment 2

Cows, Treatments, and Feeding Management--------------------------------------- 100

Pasture Intake Measurements and Sample Collection and Analyses ------------------- 101

Statistical Analyses (Experiments 1 and 2) -------------------------------------------------102

RESULTS AND DISCUSSION

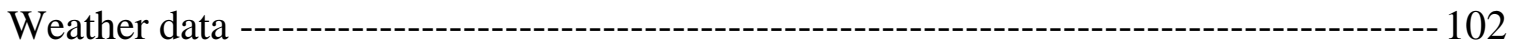

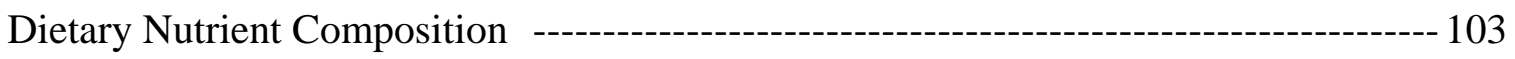

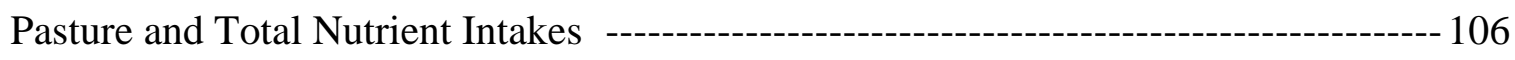

Milk Production and Composition ------------------------------------------------------------ 110

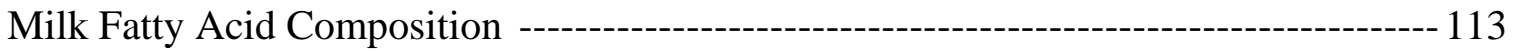

Body Weights and Body Condition Scores ----------------------------------------------- 116

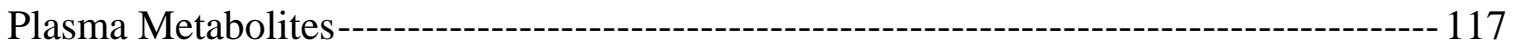

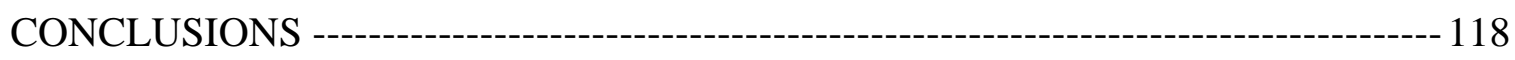

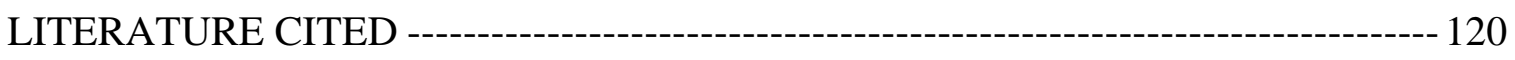

\section{CHAPTER 4}

CONTINUOUS CULTURE FERMENTATION OF DAIRY DIETS WITH VARYING 


\section{LEVELS OF TOTAL MIXED RATION AND FORAGE}

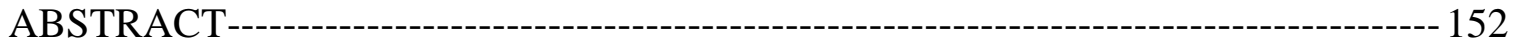

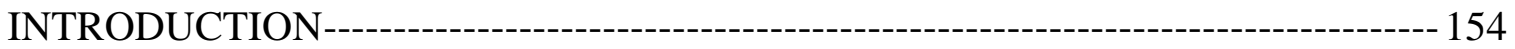

MATERIALS AND METHODS

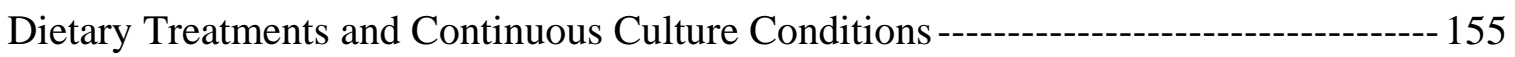

Feeding Schedule, Sampling and Analyses, and Fermentation Assessment-------------- 157

Diet Characterization ----------------------------------------------------------------------------- 158

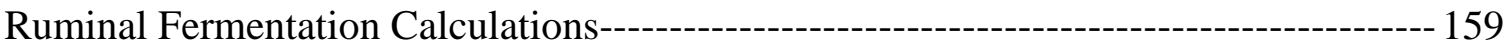

Experimental Design and Statistical Analysis -------------------------------------------------- 160

RESULTS AND DISCUSSION

Diet Characteristics------------------------------------------------------------------------------------- 161

Fermentation Assessment

Volatile Fatty Acids --------------------------------------------------------------------------------- 163

Culture pH, Ammonia $N$ and Methane Production ---------------------------------------- 167

Substrate Partition, Microbial Biomass and Microbial Efficiency ------------------------ 171

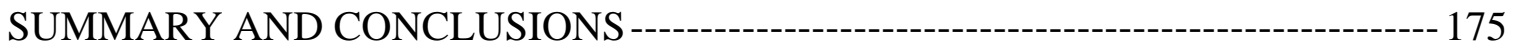

LITERATURE CITED --------------------------------------------------------------------------177

\section{CHAPTER 5}

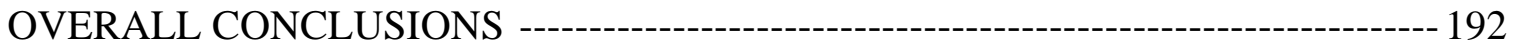




\section{LIST OF TABLES}

CHAPTER 3

Table 1. Ranges, means, standard errors of calibration (SEC), standard errors of crossvalidation (SECV), and associated coefficients of determination (R2) for various constituents of annual ryegrass predicted by near-infrared reflectance spectroscopy --- 130

Table 2. Ingredient and chemical composition (mean $\pm \mathrm{SE}$ ) of the total mixed ration (TMR) offered to all cows during Experiment 1 (F2004) and 2 (S2005)

Table 3. Nutritive value of hand-plucked weekly composites of annual ryegrass samples, Experiment 1, F2004 $-132$

Table 4. Nutritive value of hand-plucked weekly composites of annual ryegrass samples, Experiment 2, S2005

Table 5. Nutritive value of annual ryegrass herbage mass samples by week, Experiment 1, F2004

Table 6. Nutritive value of annual ryegrass herbage mass samples by week, Experiment 2, S2005

Table 7. Dry matter, CP, NDF, and net energy intake of cows offered varying amounts of TMR and grazing pasture, Experiment 1, F2004

Table 8. Dry matter, CP, NDF, and net energy intake of cows offered varying amounts of TMR and grazing pasture, Experiment 2, S2005-

Table 9. Milk production and milk composition of cows offered varying amounts of TMR and grazing pasture, Experiment 1, F2004---------------------------------138

Table 10. Milk production and milk composition of cows offered varying amounts of TMR and grazing pasture, Experiment 2, S2005------------------------------------139

Table 11. Fatty acid profiles of TMR and pasture grazed by cows in the fall (F2004) and

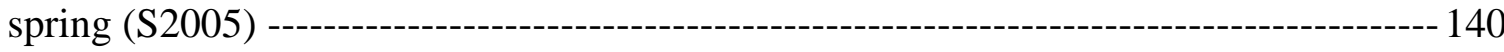

Table 12. Milk fatty acid composition from cows offered varying amounts of TMR and

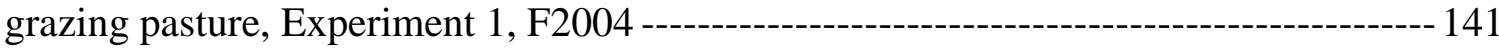

Table 13. Milk fatty acid composition from cows offered varying amounts of TMR and grazing pasture, Experiment 2, S2005 --------------------------------------142

Table 14. Body weights and body condition scores of cows offered varying amounts of TMR and grazing pasture, Experiment 1, F2004----------------------------------143 


\section{LIST OF TABLES (CONT.)}

Table 15. Body weights and body condition scores of cows offered varying amounts of TMR and grazing pasture, Experiment 2, S2005--------------------------------------------- 144

Table 16. Plasma metabolites of cows offered varying amounts of TMR and grazing

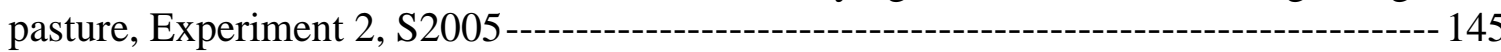

\section{CHAPTER 4}

Table 1. Ingredients of the total mixed ration (TMR) added to the continuous culture vessels

Table 2. Chemical composition (mean \pm SE) of the total mixed ration (TMR) and forage added to the continuous culture vessels

Table 3. Forage/concentrate ratios and chemical composition of the diets added to the continuous culture vessels

Table 4. Concentration and production of VFA in continuous cultures receiving varying amounts of TMR and forage

Table 5. Ruminal $\mathrm{pH}$, ammonia- $\mathrm{N}\left(\mathrm{NH}_{3}-\mathrm{N}\right)$, and methane $\left(\mathrm{CH}_{4}\right)$ production in continuous cultures receiving varying amounts of TMR and forage 190

Table 6. Substrate partition, fermentability, microbial N flow, and microbial efficiency in continuous cultures receiving varying amounts of TMR and forage 191 


\section{LIST OF FIGURES}

CHAPTER 3

Page

Figure 1. Crude protein concentration of hand-plucked weekly composite samples of annual ryegrass (Experiment 1, F2004) ------------------------------------------------- 146

Figure 2. Average percentage of leaf and stem fractions of annual ryegrass (DM basis) in the fall of 2004 (Experiment 1, F2004)------- 147

Figure 3. Average percentage of leaf and stem fractions of annual ryegrass (DM basis) in the spring of 2005 (Experiment 2, S2005) ---------------------------------------------- 148

Figure 4. Average pasture DMI estimated using a herbage mass disappearance method (HDM) and an animal performance method (APM) of cows offered varying amounts of TMR and grazing pasture in the fall of 2004, Experiment 1, F2004

Figure 5. Average pasture DMI estimated using a herbage mass disappearance method (HDM) and an animal performance method (APM) of cows offered varying amounts of TMR and grazing pasture in the spring of 2005, Experiment 2, S2005---------------- 150 


\section{CHAPTER 1}

INTRODUCTION 


\section{INTRODUCTION}

Dairy confinement feeding systems are widely used throughout the U.S. These feeding systems are based on some combination of conserved forages, grain-based concentrates, protein sources, by-products, minerals and vitamins. This feeding system, typically fed as a total mixed ration (TMR), has been proposed to increase feed efficiency in dairy herds, while maximizing milk production of high genetic merit cows. Several advantages have been attributed to this feeding system such as the elimination of feed sorting, relative simplicity in the determination of feed intake and monitoring of feed costs, and the possibility of introducing other feedstuffs into the diet. Total mixed rations in well managed herds are capable of sustaining over $10,000 \mathrm{~kg}$ of milk per lactation, with feed costs representing, on average, over $50 \%$ of total production costs (Moore, 1998; Short, 2004).

Dairy farming in the U.S. is under increasing pressure due to a decline in milk prices and rising environmental concerns relative to waste management issues, including nutrient losses. A scenario led by low milk prices and narrow profit margins during the last two decades has caused some dairy farmers to look for alternative and more profitable feeding systems (Muller and Fales, 1998). In addition to the search for low-cost feeding systems, environmentally-friendly practices have resulted in an increasing interest in pasture-based dairy farming in southeastern U.S. Previous long-term studies conducted in the Mid-Atlantic region have shown that pasture-based dairying can be competitive in terms of profitability (White et al., 2002). Further, they have resulted in minimal environmental impact (White et al., 2001) compared with the more traditional confinement system. Several simulation models (Parker et al., 1992), enterprise budget analysis (Moore, 1998) and surveys (Hanson et al., 1998; Dart et al., 1999) conducted in the Northeastern and Mid-Western regions of the 
U.S. have shown reduced input costs and increased net returns for pasture-based dairy systems.

Dairy farm numbers in the U.S. are declining severely. This trend is reportedly higher for the family-operated section of the industry located in the Mid-Atlantic and Southern regions. In North Carolina, dairy farm numbers have decreased by $90 \%$ since 1960 , and currently, farm numbers are less than half the number of dairy farms in 1990. Despite these downward trends, the region could still have a competitive dairy industry. Three major factors support the potential competitiveness of the region: 1) Grazing of pastures has surfaced as a forthcoming solution to some of the nutrient-management, expense-cutting, locally-produced and friendly-neighboring challenges now encountered on intensively managed dairy farms 2) an extended grazing season in the Mid-Atlantic region, as compared to the Northeast and Mid-West regions, allowing for reduced feeding costs for a longer period of time throughout the year and 3) the region has an unbalanced supply-demand relationship, i.e., more milk and milk products are consumed than those sustained by local milk production.

Pasture-based dairying, however, has its own shortcomings. Supplemental energy needs to be fed to high producing dairy cows on pasture in order to reach their genetic potential for milk production. A substantial body of evidence from research studies conducted in the U.S. comparing dairy confinement systems with pasture-based systems (with or without supplementation) consistently shows reduced dry matter intake (DMI) (Kolver and Muller, 1998; Reis and Combs, 2000; Soriano et al., 2001; Tucker et al., 2001; White et al., 2001; Bargo et al., 2002), milk production (Kolver and Muller, 1998; Reis and Combs, 2000; Soriano et al., 2001; Tucker et al., 2001; White et al., 2001; Bargo et al., 2002; 
Fontaneli et al., 2005), body weights (BW) (Kolver and Muller, 1998; Bargo et al., 2002; Fontaneli et al., 2005), and body condition scores (BCS) (Kolver and Muller, 1998; Soriano et al., 2001; Tucker et al., 2001; Washburn et al., 2002; Bargo et al., 2002) from pasturebased dairying. These factors have contributed to reluctance among many dairy farmers to use pasture in their dairy systems (Bargo et al., 2002; White et al., 2002).

Most of the previously mentioned comparative studies used dietary treatments that consisted of some combination of pasture plus concentrate supplementation compared with a TMR. Such comparisons included an all-pasture diet vs. TMR (milk yield averaged 29.6 vs. $44.1 \mathrm{~kg} / \mathrm{d}$ milk, respectively; Kolver and Muller, 1998); three levels of a corn-based concentrate supplementation, including an unsupplemented group (milk yield averaged 21.8, 26.8, and $30.4 \mathrm{~kg} / \mathrm{d}$ milk for 0,5 , and $10 \mathrm{~kg}$ concentrate DMI, respectively; Reis and Combs, 2000); intensive pasture grazing allotted either during the morning or the afternoon vs. $100 \%$ TMR (milk yield averaged 27.6, 28.2, and $29.1 \mathrm{~kg} / \mathrm{d}$ milk, respectively; Soriano et al., 2001); unrestricted access to pasture vs. a corn silage-based TMR (milk yield ranged from 21.3 to $15.9 \mathrm{~kg} / \mathrm{d}$ and 22.5 to $26.2 \mathrm{~kg} / \mathrm{d}$, respectively; Tucker et al., 2001); pasture-based diets vs. TMR feeding (23.3 vs. $25.9 \mathrm{~kg} / \mathrm{d}$ milk for Holsteins and 17.6 vs. $20.2 \mathrm{~kg} / \mathrm{d}$ milk for Jerseys, respectively; Washburn et al., 2002; White et al., 2002); pasture plus concentrate, a TMR supplemented with pasture, and TMR feeding $(28.5,32.0$, and $38.1 \mathrm{~kg} / \mathrm{d}$ milk, respectively; Bargo et al., 2002), and two pasture-based diets vs. TMR feeding (25.1 vs. $29.8 \mathrm{~kg} / \mathrm{d}$ milk, respectively; Fontaneli et al., 2005).

Published information on dynamic feeding systems that use both pasture and TMR are scarce in the U.S. Limited research is available evaluating the use of TMR on animal productivity with increasing levels of pasture supplementation, a useful approach for dairy 
producers to assess the transitioning towards the adoption of pastoral dairying. I am not aware, however, of published studies that examine performance of dairy cows fed different combinations of partially-restricted TMR feeding and high-quality pasture grazing, in addition to an all-TMR control diet. Feeding systems that use both TMR and pasture are being increasingly referred to as partial mixed rations (PMR) where the pasture grazed by the cows is not physically part of the TMR. The objectives of this research were: 1) to evaluate pasture and total DMI, milk production and composition, and feed efficiency using a positive control diet (an entire bunk feeding system) compared with three varying PMR; 2) to adequately addresses the extent to which TMR feeding can be restricted without critically affecting milk and milk components production; 3 ) to evaluate in vitro fermentation patterns, intermediates, and end products underlying the production responses obtained from the different TMR-restricted dietary treatments; and 4) to examine fatty acid profiles with special interest in conjugated linoleic acid concentration in feed, rumen fluid, and milk from all four dietary treatments tested. The approach of focusing on a narrower range of feeding systems has not been explored while addressing the issue of where the break point is in terms of performance under increasing pasture DMI. 


\section{LITERATURE CITED}

Bargo, F., L. D. Muller, J. E. Delahoy, and T. W. Cassidy. 2002. Performance of high producing dairy cows with three different feeding systems combining pasture and total mixed rations. J. Dairy Sci. 85:2948-2963.

Dartt, B. A., J. W. Lloyd, B. R. Radke, J. R. Black, and J. B. Kaneene. 1999. A comparison of profitability and economic efficiencies between management-intensive grazing and conventionally managed dairies in Michigan. J. Dairy Sci. 82:2412-2420.

Fontaneli, R.S., L. E. Sollenberger, R. C. Littell, and C. R. Staples. 2005. Performance of lactating dairy cows managed on pasture-based or in freestall barn-feeding systems. J. Dairy Sci. 88:1264-1276.

Hanson, G. D., L. C. Cunningham, M. J. Morehart, and R. L. Parsons. 1998. Profitability of moderate intensive grazing of dairy cows in the northeast. J. Dairy Sci. 81:821-829.

Kolver, E. S., and L. D. Muller. 1998. Performance and nutrient intake of high producing Holstein cows consuming pasture or a total mixed ration. J. Dairy Sci. 81:1403-1411.

Moore, K. C. 1998. Economics of grass for dairy cattle. Pages 373-391 in Grass for Dairy Cattle (Eds. J. H. Cherney and D. J. R. Cherney). CAB International, New York, NY.

Muller, L. D., and S. L. Fales. 1998. Cool-season grass pastures for dairy cattle. Pages 335350 in Grass for Dairy Cattle (Eds. J. H. Cherney and D. J. R. Cherney). CAB International, New York, NY.

Parker, W. J., L. D. Muller, and D. R. Buckmaster. 1992. Management and economic implications of intensive grazing on dairy farms in the northeastern states. J. Dairy Sci. 75:2587-2597.

Reis, R. B., and D. K. Combs. 2000. Effects of increasing levels of grain supplementation on 
rumen environment and lactation performance of dairy cows grazing grass-legume pasture. J. Dairy Sci. 83:2888-2898.

Short, S. D. 2004. Characteristics and Production Costs of U.S. Dairy Operations. USDA Statistical Bulletin No. 974-6. 20 pp. ARMS of Milk Producers, USDA, ERS.

Soriano, F. D., C. E. Polan, and C. N. Miller. 2001. Supplementing pasture to lactating Holsteins fed a total mixed ration. J. Dairy Sci. 84:2460-2468.

Tucker, W. B., B. J. Rude, and S. Wittayakun. 2001. Case Study: Performance and economics of dairy cows fed a corn silage-based total mixed ration or grazing annual ryegrass during mid to late lactation. Prof. Anim. Sci. 17:195-201.

Washburn, S.P., S. L. White, J. T. Green, Jr., and G. A. Benson. 2002. Reproduction, mastitis, and body condition of seasonally calved Holstein and Jersey cows in confinement or pasture systems. J. Dairy Sci. 85:105-111.

White, S. L., G. A. Benson, S. P. Washburn, and J. T. Green, Jr. 2002. Milk production and economic measures in confinement or pasture systems using seasonally calved Holstein and Jersey cows. J. Dairy Sci. 85:95-104.

White, S. L., R. E. Sheffield, S. P. Washburn, L. D. King, and J. T. Green, Jr. 2001. Spatial and time distribution of dairy cattle excreta in an intensive pasture system. J. Environ. Qual. $30: 2180-2187$. 


\section{CHAPTER 2}

LITERATURE REVIEW 


\section{THE USE OF PASTURE IN HIGH-PRODUCING DAIRY COW FEEDING SYSTEMS IN SOUTHEASTERN U.S.}

The progression of the U.S. dairy industry over the last 50 years has been distinctive compared with other developed dairy regions around the globe. From the early second half of the $20^{\text {th }}$ century, research conducted in the U.S. showed the advantages of allocating a relatively large proportion of land to the growing of high-yielding, high-quality crops for forage or energy conservation (i.e. corn and alfalfa) and as high-protein supplement ingredients (i.e. soybeans) (Clark and Kanneganti, 1998). This shift in land use reduced land for grazing purposes, and was stimulated by a favorable milk price/feed cost relationship that led farmers to intensify production per cow (Muller and Fales, 1998). With availability of affordable machinery for large scale forage and grain harvesting, processing, and storage along with relatively low fuel and fertilizer costs, pasture-based dairying was replaced by

confinement systems which allowed for more control of rations for high production. Dairy rations based on crop products are of higher cost but are able to support higher per cow milk yield than pasture-based dairying (Bargo et al., 2003).

The introduction of the TMR concept improved the efficiency of feeding confined dairy cows (Coppock et al., 1981). Crops were harvested at optimal nutritive value and dairy cows were fed indoors with a mixed ration of forage and concentrate that tended to maximize production per cow. Consequently, mixer wagons are commonly found on dairy farms, regardless of herd size or housing system. The TMR system allowed feed ingredients to be blended together and providing the blend was mixed thoroughly enough to prevent separation and sorting, cows consumed a nutritionally balanced diet in every bite. Following this trend, the average milk production per cow increased from about $3200 \mathrm{~kg}$ in 1960 to $8890 \mathrm{~kg}$ in 
2005 (National Agricultural Statistics Service, 2006).

In contrast, during this same period, researchers in Western Europe, New Zealand, Australia, Argentina, and other countries, had focused their attention on understanding pasture grass and legume physiology, sward dynamics, and grazing management, to increase per hectare production of milk solids (Fick and Clark, 1998). Pasture-based dairying is capable of low-cost milk production with high milk output per unit of land. Efficient lowcost farming systems have evolved, usually through necessity, to survive low milk values and relatively expensive bought-in or imported supplements. Pasture-based, heavily stocked feeding systems in New Zealand are capable of yielding over $1000 \mathrm{~kg}$ of milk solids per hectare with no imported supplementation. Over $1500 \mathrm{~kg}$ of milk solids can be produced per hectare with relatively low levels of imported supplementation (Penno et al., 1996). In a similar fashion, forage-based feeding systems in Ireland that included annual DMI per cow of 3500,1400 , and $500 \mathrm{~kg}$ from freshly-grazed pasture, grass silage, and concentrates, respectively, were highly profitable at a stocking rate of 2.6 cows per hectare (Dillon and Crosse, 1997). Although each system considered here has developed a complex display of technology and industry infrastructure, the milk price-to-feed cost ratio has been, and seemingly will continue to be, the driving force in determining the type of dairy feeding system chosen (Clark and Kanneganti, 1998).

The objective of this review is to summarize the effects of feeding increasing amounts of pasture to cows fed TMR-based diets and to examine the use of these partial mixed rations for high-producing dairy cows, with a special focus on pasture and total DMI intake, milk yield and composition, and ruminal digestion. This review focuses on data from the U.S., but also includes information from other countries where grass-based agriculture is 
a major provider of dairy nutrients (i.e. New Zealand, Australia, Ireland, U.K., Argentina, and others). Also, for the purpose of this review, the term pasture-based system will refer to those systems where grazing provided for a minimum of $30 \%$ of the daily DM intake of lactating dairy cows.

\section{DAIRY GRAZING SYSTEM NOTION}

Grazing systems are defined as "integrated combinations of animal, plant, soil, and other environmental components and the grazing methods by which the systems are managed to achieve specific goals" (Forage and Grazing Terminology Committee, 1992). Pasturebased dairy systems exhibit a highly complex assemblage of several factors related to animal performance and pasture productivity including, among other, pasture growth, pasture harvesting efficiency, and feed conversion efficiency (Holmes et al., 1984). Consumption of high quality forage is the main force driving animal performance in pasture-based systems. High quality forage has typically been defined as the green, leafy, upper portion of the canopy with $\sim 18$ to $24 \%$ dry matter (DM) with a crude protein $(\mathbf{C P})$ concentration of 18 to $25 \%$, a fiber concentration of 40 to $50 \%$ as neutral detergent fiber (NDF), and an energy concentration of 1.53 to $1.67 \mathrm{Mcal}$ of net energy for lactation $\left(\mathbf{N E}_{\mathbf{l}}\right)$ per $\mathrm{kg}$ of DM (Cherney and Allen, 1995).

\section{DAIRY GRAZING RESEARCH IN EASTERN U.S.}

Sustainable agriculture continues to be widely discussed throughout the U.S. agricultural industry, and renewed interest in intensive dairy grazing systems has surfaced as a result of such debate. In addition, dairy grazing systems are gaining in importance as a way of lowering costs while maintaining high milk production (Fales et al., 1993). A remarkable body of grazing literature has emerged in the last two decades in the Eastern U.S. and several 
research groups including Clemson University, Cornell University, Michigan State University, North Carolina State University, The Ohio State University, The Pennsylvania State University, University of Florida, University of Illinois, University of Wisconsin, Virginia Polytechnic Institute and State University are partly responsible for giving pasturebased dairying the opportunity for a comeback in the region.

\section{Transitioning from dairy grazing to confinement feeding systems}

In contrast to the rest of the world, the notion that grass could play a major role in Eastern U.S. dairy nutrition is a relatively new one. The first peer-reviewed article on dairy grazing findings published by the Journal of Dairy Science was authored by Woodward (1936). After evaluating a series of 15 trials conducted during 1932 and 1933 in Beltsville, MD, Woodward (1936) reported daily milk yields (11.1 vs. $16.6 \mathrm{~kg} / \mathrm{d})$, milk fat yields (515 vs. $525 \mathrm{~g} / \mathrm{d}$ ), milk fat contents (4.62 vs. $3.14 \%$ ), and DMI (10.3 vs. $12.2 \mathrm{~kg} / \mathrm{d}$ ) for selected Jerseys and Holsteins, respectively, on pasture-only diets (orchardgrass/white clover).

The findings from the first replicated grazing trials using lactating dairy cows, however, were not published until the mid 50s (Seath et al., 1956; Lassiter et al., 1956; both articles cited by Burns, 2005). Seath et al. (1956), from the University of Kentucky, Lexington, reported total digestible nutrients (TDN) yield per surface unit, milk production persistency, and body weight changes for lactating dairy cows. After evaluating eight 0.8 -ha plots seeded to two pastures each of Kentucky bluegrass, orchardgrass, bromegrass, and Kentucky 31 fescue during three years, Seath et al. (1956) concluded that only minor differences existed between the first three forage species tested. Kentucky 31, however, exhibited lower TDN yields due primarily to rapid declines in milk production and BW losses. Daily DMI, reported as $\mathrm{kg}$ per $454 \mathrm{~kg} \mathrm{BW}$, were 10.1, 11.0, 10.2, and $9.1 \mathrm{~kg}$ for cows 
grazing Kentucky bluegrass, orchardgrass, bromegrass, and Kentucky 31 fescue, respectively (Lassiter et al., 1956). Later during that same year, Pratt and Davis (1956) published the findings of a three-year trial conducted to determine the minimum amount of protein needed to supplement a bromegrass/alfalfa/Ladino clover pasture diet. Pratt and Davis (1956) concluded that grain mixes containing $\sim 10 \%$ crude protein fed to Jerseys supported $13.6 \mathrm{~kg}$ of $4 \%$ fat-corrected milk (FCM) production, and that feeding grain rations with a higher protein content did not result in higher milk yields.

In the late 50s, the U.S. dairy industry transitioned from being predominantly pasture-based to confined feeding and management systems. Until then, the predominant source of nutrients came from grazed pastures for most dairy herds, followed by hay and silage. Grazing months for the north (including the Mid-West and Northeast) and Southeast U.S. ranged from 3 to 5 and 10 to 12 , respectively, establishing clear seasonal and geographical variations in milk supply, with corn silage emerging strongly as a supplemental forage source for the former and supplemental hay for the latter region (Coppock et al., 1981). Although many significant contributions to the field of intensified feeding strategies are not described here, several outstanding reviews written in the 50s and 60s describing different aspects of dairy nutrition including nutritive value and blending of feeds (Blaxter, 1956; Rakes, 1969) and energy requirements and feed utilization (Reid, 1956; Huffman, 1961; Reid et al., 1966; Brown, 1966) challenged the then known concepts of energy and protein requirements of high-producing dairy cows. Grain allocations, though far from the amounts being offered to high-producing dairy cows today, were an increasing feeding practice generally in response to production levels and usually offered during milking times (Coppock et al., 1981). While intensifying practices had begun much earlier, Huffman (1961) 
noted that the response of high-producing dairy cows to additional concentrates was often limited by the practice of parlor feeding, and suggested a more 'liberal' strategy of grain feeding based on milk yield. A considerable response in milk yield was reported (an average of $1,247 \mathrm{~kg}$ for three large commercial field trials conducted in 1960,1961, and 1962) from the 735 Holsteins tested. Trials such as these led to the concept of 'challenge' feeding which included the feeding of grain in amounts offered equivalent to $2 \% \mathrm{BW}$. Although initial concerns regarding ruminal function and udder health from high-grain feeding were established (Huffman, 1961; Rakes, 1969), the concept of challenge feeding became widely adopted and large increases in production occurred.

The concept of ration balancing relying on the use of conserved forages and concentrates led to major increases in cow performance. An early study by McCoy et al. (1966) using complete rations (defined as those with all the forage and grain ingredients blended together and formulated to a specific nutrient concentration) compared three feeding strategies. These included different corn-based concentrate amounts offered (2.5 kg DM per $\mathrm{kg} 4 \% \mathrm{FCM}$, treatment 1 ; vs. ad lib offer, treatment 2) in combination with alfalfa/bromegrass hay; and a complete ration ( $70 \%$ concentrate, $30 \%$ coarsely-ground hay, treatment 3). Average daily DMI, 4\% FCM, and fat yields were 15.5, 19.0, and $16.7 \mathrm{~kg}$ DM; 17.1, 16.6, and $18.4 \mathrm{~kg}$ milk; and $0.67,0.59$, and 0.70 , respectively, for treatments 1,2 , and 3. A second trial was conducted to examine ad libitum feeding of different complete rations that contained equal proportions (30\%) of 1) coarsely-ground hay, 2) corn cobs, or 3) cottonseed hulls. Average daily DMI, 4\% FCM, and fat yields were 17.9, 18.1, and $20.2 \mathrm{~kg}$ DM; 20.3, 19.5, and 20.4 kg milk; and 0.77, 0.74, and 0.78, respectively, for treatments 1, 2, and 3. Based on the two trials, it was concluded that a complete ration containing a 30:70 
forage-to-concentrate ratio was readily consumed by lactating dairy cows while supporting high levels of milk production (McCoy et al., 1966).

By the mid 1960s the bulk of forage research in eastern U.S. emphasized the use of technology in support of conserved forage rather than pasture. Improvements in the area of nutrition led to refinements in the use of complete rations or totally mixed rations that allowed the blending of a nutritionally balanced diet of forage, grains, and other feedstuffs (Fales et al., 1993), a feeding system that would become widespread in the years to come. Coppock (1977) summarized the advantages and disadvantages of feeding TMR. Among the advantages cited by the author are the following: a) sorting is minimized; b) free-choice minerals are not needed; c) given enough space, lactation grouping can be easily performed; d) unpalatable ingredients may be masked; e) formulation, if kept flexible, allows for the inclusion of new ration ingredients; and f) complete rations are beneficial to continuous rumen function and ingesta flow as opposed to slug feeding of concentrates. Disadvantages are usually related to capital and labor expenses, such as the need for (or contracting of) silage-making machinery, storage facilities, bunk space and feeding area, and expanded effluent disposal facilities, among others. It must be noted that rations must be carefully formulated and continually checked, and large amounts of long-particle hay are difficult to incorporate into rations.

\section{Renewed interest in pasture-based feeding systems}

Pasture-based feeding systems regained interest in the U.S. dairy industry over the last two decades (Bargo et al., 2003). Based on the role of farmers and economics, Fales et al. (1993) described two major differences between the current pasture movement and the one that took place throughout the 1930s and 1940s. Currently, dairy producers, rather than 
researchers and extension specialists, are taking leadership in adopting and promoting pasture management systems. This approach has been assisted by an assortment of effective, lowcost fencing and watering systems that allow for flexible pasture management, adapting to seasonal changes in forage quality and availability.

Linked to the previous factor, a second major difference in modern grass-based dairying described by Fales et al. (1993) has been the need to adapt to economic pressures in order to remain profitable by drastically cutting costs. Economic benefits can be derived from lower costs for feed, labor, utilities, and herd health for grazing systems (Hanson et al., 1998). The use of pasture results in low cost dairy feeding systems because grazed forage is one of the cheapest sources of nutrients (Clark and Kanneganti, 1998). Descriptive studies have shown that moderately sized farms ( 80 to 100 cows) can remain competitive when they reduce net feed and crop expenses, labor expenses, and machinery costs (Fales et al., 1993; Soder and Rotz, 2001; Tauer, 2001).

During the 1990s, a number of farm surveys (Emmick and Toomer, 1991; Hanson et al., 1998; Dartt et al., 1999), simulation models (Parker et al., 1992), and budget analysis (Moore, 1998) conducted in the Northeastern and Mid-Western regions of the U.S. reinforced the concept of reduced input costs for pasture-based dairy systems. After a comprehensive survey of 15 New York dairy farms, Emmick and Toomer (1991) reported an annual average savings of $\$ 153$ per cow. This is in agreement with potential savings of $\$ 121$ per cow for a grazing system compared to a typical (80-ha farm with 53 cows and 48 replacements) confinement feeding system in Pennsylvania (Parker et al., 1992). The analysis by Parker et al. (1992) indicated that potential annual operating costs could be reduced by $\$ 6000$ to $\$ 7000$ through the adoption of intensive grazing, however the overall income would 
not be improved if production per cow dropped by $\sim 470 \mathrm{~kg}$ milk per lactation with this feeding approach.

The economics of moderately intensive $(15 \%$ or more of the forage offered derived from grazing) vs. extensive grazing (less than $15 \%$ of the forage offered derived from grazing) were examined by Hanson et al. (1998) for Northeastern U.S. Although farms that employed moderately intensive grazing had $23 \%$ fewer cows and produced $14 \%$ less milk per cow, no significant difference in net income per cow was found between groups. It was interesting to note that the authors anticipated a decline in time of the traditional approach of turning cows into one or two large permanent pastures for the summer season due to poor economics from such practice. Often, pastures become under-managed, under-valued, and poorly understood resources (Moore, 1998). Common features of the above-mentioned studies include a) grass dairying competitiveness by lowering feed costs via grazing while using supplemental feeds to maintain viable milk production levels; b) shared concerns related to variability in forage biomass production within and between years; and c) the decline in milk production from pasture-based systems.

Feed costs are the single largest expense in dairy enterprises and typically represent between 45 and 55\% of total cash costs (Moore, 1998). Members of the Eastern Uplands Region showed that total feed costs represented $68 \%$ and $51 \%$ of total operating and total operating plus ownership costs in 2000 , respectively. Total cost of producing milk in the Mid-Atlantic region averaged $\$ 18.23$ per hundredweight (cwt) in 2000. Correspondingly, total feed costs for the same year in the Fruitful Rim-West region (Southwest and Northwest-producing states) averaged $\$ 11.58$ per cwt, representing both extremes of milk production costs with all five ERS (Economic Research Service) resource regions considered 
(the above mentioned regions plus Heartland, Northern Crescent-West, and Northern Crescent-East; Short, 2004). Moreover, only one out of four dairy producers in the Eastern Uplands region was able to cover total operating plus ownership costs for the average allmilk price of 2000 ( $\$ 12.40$ per cwt; Short, 2004).

\section{PERFORMANCE AND DRY MATTER INTAKE OF GRAZING COWS}

\section{Performance and dry matter intake of grazing cows on pasture only diets}

Voluntary intake is the single most important factor determining animal performance. Although several theories about the factors controlling pasture DMI have been presented (Hodgson, 1985; Allen, 1996; Forbes, 1996; Faverdin, 1999; Allen, 2000; Baile and DellaFera, 2002), they are not the objective of this review. Pasture DMI, however, has reportedly been affected by three major constraining factors: a) nutrient requirements or 'feeding drive';

b) factors ascribed to digestive tract distension, and digestibility and rate of passage of the feed or 'physical satiety'; and c) behavioral constraints as a result of combined environmental, pasture, and animal factors (Hodgson and Brookes, 1999).

High-producing dairy cows can reach DMI levels approaching (or even beyond) $4.0 \%$ of body weight i.e., $24 \mathrm{~kg} \mathrm{DM}$ for a $600-\mathrm{kg}$ cow, however most grazing situations report maximum DMI levels of $\sim 3.0 \% \mathrm{BW}$ or lower, suggesting that grazing systems are far from reaching potential DMI levels to sustain maximum daily milk yields (Leaver, 1985). Pasture DMI of high-producing dairy cows was reported to be $\sim 3.5 \% \mathrm{BW}$ when pasture quantity and quality were not restricting (i.e. $21 \mathrm{~kg}$ DM for a $600-\mathrm{kg}$ cow; Mayne and Wright, 1988). These levels of total intake are still lower than those achieved with supplemental or TMR feeding systems. Ulyatt and Waghorn (1993) emphasized that daily per cow performance in pasture-based systems is limited to less than $30 \mathrm{~kg}$ milk due to low 
pasture DMI and a nutrient supply that may differ from that required by high-producing cows. Beever and Thorp (1997) suggested that the decline in DMI is due to physical constraints (digestion and removal of ingested material) as well as time constraints (time allotted to either fresh forage prehension or grazing, or to rumination and resting) in addition to considerable amounts of water associated with fresh forage intake.

Assuming a scenario where daily DMI and energy density values are $18 \mathrm{~kg}$ DM (3.0\% BW for a $600-\mathrm{kg}$ cow) and $1.70 \mathrm{Mcal} / \mathrm{kg} \mathrm{DM}$ of $\mathrm{NE}_{1}$ (Muller and Fales, 1998), respectively, the energetics from grass intake would theoretically support daily milk production of $\sim 29 \mathrm{~kg}$ (3.5\% milk fat and $3.2 \% \mathrm{CP}$, second-lactation Holstein), partitioning $\sim 10.7$ and 20.0 Mcal of $\mathrm{NE}_{1}$ towards maintenance and milk production, respectively, provided there is no significant change in body tissue (NRC, 2001). In practice, good quality grazed grass is unlikely to support daily production levels beyond $27 \mathrm{~kg}$ of milk (Meijs, 1983; Berzaghi et al., 1996; Beever and Thorp, 1997; Dalley et al., 2001).

A number of studies have shown that DMI per bite is a critical component of pasture intake (Hodgson, 1985; Laca et al., 1992). Following the ingestive process model pDMI = $\mathbf{G T} * \mathbf{B R} * \mathbf{B M}($ where pDMI $=$ pasture DMI, $\mathrm{kg} / \mathrm{d} ; \mathrm{GT}=$ grazing time, $\mathrm{min} / \mathrm{d} ; \mathrm{BR}=$ bite rate, number of bites/min; and $\mathrm{BM}=$ bite mass, g DM), Leaver (1986) examined some of the limitations to performance for cows on pasture-only diets. By relating BM to pDMI, the author predicted a maximum daily pasture DMI of $17.3 \mathrm{~kg}$ DM from a BM of $0.86 \mathrm{~g}$ DM supporting a daily production of $\sim 22$ to $26 \mathrm{~kg}$ milk. From these and other observations, Leaver (1986) suggested that high-producing dairy cows could obtain all of their required nutrients from pasture provided high pasture allowances, high $\mathrm{NE}_{1}$ contents, and low sward contamination were achieved. Such conditions, however, are likely to be present for only a 
few weeks during the spring (Leaver, 1986; Clark et al., 1997). The grazing ingestive model will be explored in more detail later in this review.

Data from grazing studies evaluating a more frequent allocation of fresh pasture to high-producing dairy cows have been reported. A more frequent allocation of fresh forage (six vs. one allocation daily) to early-lactation dairy cows did not result in increased milk yields (Dalley et al., 2001). Two Australian experiments examined the hypothesis that more frequent pasture offerings of perennial ryegrass (Lolium perenne) would result in increased DMI and milk yields (Dalley et al., 2001). Daily pasture allowances of 40 vs. $65 \mathrm{~kg}$ DM per cow (experiment 1) were offered either once or six times daily in equal allotments. Average daily pasture DMI (15.6 vs. $15.9 \mathrm{~kg} \mathrm{DM})$, grazing time (9.4 vs. 9.5 h), milk production (25.4 vs. $25.2 \mathrm{~kg}$ ), and milk composition did not differ between the once-a-day and six-a-day feeding groups. Similarly, both feeding-frequency groups exhibited similar daily pasture DMI (15.2 vs. $16.3 \mathrm{~kg}$ DM for once- vs. six-a-day feeding groups, respectively) when offered an overall pasture allowance of $50 \mathrm{~kg}$ DM per cow (experiment 2). Milk production, however, was greater for cows offered a fresh allotment once a day vs. six times a day (26.7 vs. $25.7 \mathrm{~kg}$ milk, $P<0.05)$. Increasing pasture allowance increased pasture DMI (17.9 vs. $13.6 \mathrm{~kg} \mathrm{DM}, P<0.05)$ and milk production $(26.7 \mathrm{vs.} 23.9 \mathrm{~kg}$ milk, $P<0.05)$ for $65 \mathrm{vs.} 40 \mathrm{~kg}$ DM offered per cow, respectively (experiment 1, Dalley et al., 2001).

Research studies are limited in the U.S. where high-producing dairy cows are fed pasture-only diets (Bargo et al., 2003). Dry matter intake of early lactation (84 days in milk, DIM) Holsteins grazing a high quality grass-legume pasture, approximately 50\% orchardgrass (Dactylis glomerata) and 50\% alfalfa (Medicago sativa), was $13.9 \mathrm{~kg}$ DM supporting a daily production level of $21.9 \mathrm{~kg} 4 \%$ FCM (Reis and Combs, 2000). Previously, 
a comparative study conducted by Kolver and Muller (1998) reported that DMI of early lactation (59 DIM) dairy cows grazing high quality grass-based pastures during the spring was $19.1 \mathrm{~kg}$ DM (3.4\% BW) supporting a daily production level of $28.3 \mathrm{~kg} 4 \%$ FCM. Daily DMI and milk production of cows fed a TMR were $23.4 \mathrm{~kg}$ DM and $44.1 \mathrm{~kg}$ milk, respectively (Kolver and Muller, 1998). Although grazing cows consumed $4.3 \mathrm{~kg}$ less DM and $19 \%$ less energy (32.4 vs. $40.2 \mathrm{NE}_{\mathrm{l}}, \mathrm{Mcal} / \mathrm{d}$, for grazing vs. TMR-fed cows, respectively), daily intakes of CP and NDF (4.9 vs. $4.7 \mathrm{~kg} \mathrm{CP}$ and 8.5 vs. $7.6 \mathrm{~kg}$ NDF for grazing vs. TMR-fed cows, respectively) did not differ between dietary treatments, leading the authors to conclude that the difference in DM, rather than energy content per-se, was responsible for the lower energy intake and milk production.

\section{Performance and dry matter intake of cows fed pasture-based diets}

Reviews focusing on different characteristics of supplementation of pasture-based dairy diets have been reported (Leaver, 1985, 1988; Lean et al., 1996; Beever and Thorp, 1997; Clark et al., 1997; Bargo et al., 2003; Doyle et al., 2005), but consideration is given here to supplementation strategy, pasture and total DMI, and milk production and composition. Research on the decline in production during intensive grazing has shown that energy and protein are usually the most limiting factors in maximizing performance of highproducing dairy cows, and have received the most attention in evaluation systems (Van Soest, 1994). The former has clearly been established as the first-limiting nutrient for high producing dairy cows on pasture for most situations (Stockdale et al., 1990; Fales et al., 1993; Kolver and Muller, 1998). Consequently, the use of supplemental energy feeds in pasture-based systems to meet the genetic potential of dairy cows is a widespread practice (Bargo et al., 2003). 
Research in the Eastern U.S. has examined an assortment of supplementation strategies for moderate to high producing dairy cows on pasture including different energy supplements (Salinas et al., 1983; Polan et al., 1986; Hoffman et al., 1993; Holden et al., 1995; Berzaghi et al., 1996; Dhiman et al., 1999; Reis and Combs, 2000; Soriano et al., 2000; Wu et al., 2001; White et al., 2002; Delahoy et al., 2003), protein supplements (JonesEndsley et al., 1997; Hongerholt and Muller, 1998; McCormick et al., 2001), a combination of pasture plus TMR (Soriano et al., 2001; Bargo et al., 2002b), and pasture management strategies (Holden et al., 1994a; Fales et al., 1995; Bargo et al., 2002a; Fike et al., 2003; Fontaneli et al., 2005). Because most of the research has been conducted in the Midwest and Northeast U.S., it is important to note that the typical grazing season at these latitudes occurs from late April to late October, with more intensive feeding systems, such as TMR, used during the non-grazing season (Bargo et al., 2003).

Typically, grazing cows in the U.S. are supplemented with concentrates based on dry corn (Soriano et al., 2000). The energy density of corn grain and the growth of corn throughout vast regions of the U.S. make it the primary concentrate component for dairy diets. Performance and DMI of mid-lactation dairy cows (130 DIM) grazing a predominantly orchardgrass/Kentucky bluegrass (Poa pratensis) pasture and offered a corn-based concentrate, were reported by Salinas et al. (1983). During the 20-week study, concentrate was offered to meet 33,66 , or $100 \%$ of $\mathrm{NE}_{1}$ requirements above maintenance. Although pasture DMI values were not reported, concentrate DMI $(3.5,7.7,11.5 \mathrm{~kg}$ for the 33,66 , and $100 \% \mathrm{NE}_{1}$ groups, respectively) only resulted in numerical differences in milk production (19.2, 20.4, and $21.5 \mathrm{~kg}$ milk for the 33,66 , and $100 \% \mathrm{NE}_{1}$ groups, respectively). Milk protein yields were higher $(P<0.05)$ for the $100 \%$ vs. $33 \% \mathrm{NE}_{1}$ group, but milk fat yields did 
not differ between groups (Salinas et al., 1983).

Dhiman et al. (1999) compared milk production and milk components from cows on pasture diets where pasture accounted for 33,67 , or $100 \%$ of the total diet. Holstein cows grazed a mixture of bluegrass, quackgrass (Elytrigia repens), smooth bromegrass (Bromus inermis), and white clover (Trifolium repens). Cows remained unsupplemented or received $11.6 \mathrm{~kg}$ DM (33\% pasture treatment; supplement offered contained $25 \%$ alfalfa hay, $48 \%$ high moisture corn, 18\% roasted cracked soybeans, $6 \%$ soybean meal, and $2.7 \%$ mineral and vitamin mix) or $6.0 \mathrm{~kg} \mathrm{DM}$ (66\% pasture treatment; supplement offered contained 50\% alfalfa hay, $28.4 \%$ high moisture corn, $18 \%$ roasted cracked soybeans, and $3.6 \%$ mineral and vitamin mix). Daily milk, milk fat and protein yields were greatest for the $33 \%$ pasture treatment and were 24.5, 17.5, and $14.5 \mathrm{~kg}$ milk; 860, 640, and $490 \mathrm{~g}$ milk fat; and 711, 478, and $415 \mathrm{~g}$ milk protein for treatments 33,67 , or $100 \%$ pasture, respectively (Dhiman et al., 1999).

Increasing energy supplementation levels increased total DMI, milk, and protein production, and decreased pasture DMI; however 4\% FCM remained unaffected and fat yield was lowest for the highest supplementation level (Reis and Combs, 2000). Early lactation (84 DIM) Holsteins grazing a high quality grass-legume pasture remained unsupplemented or were supplemented with 5 or $10 \mathrm{~kg}$ DM of a corn-based concentrate. Total and pasture DMI were 13.9, 17.7, and 19.8 $\mathrm{kg} \mathrm{DM}(P<0.05)$; and 13.9 and 12.7 vs. $9.77 \mathrm{~kg} \mathrm{DM}(P<0.05)$, respectively, for treatments fed 0 , 5 , or $10 \mathrm{~kg}$ concentrate, respectively. Such dietary treatments supported daily production levels of $21.8,26.8$, and $30.4 \mathrm{~kg}$ milk $(P<0.05)$; 880, 830, and 750 g milk fat; and 620, 790, and $930 \mathrm{~g}$ milk protein (Reis and Combs, 2000). The decline in milk fat yield for the highest level of supplementation tested was attributed to the 
NDF content of this particular diet, calculated to be 26\% NDF (DM basis), lower than the $28 \%$ recommended at the time (NRC, 1989), and lower than the 19\% NDF from forage for diets not fed as total mixed rations currently being recommended (NRC, 2001).

Although $\mathrm{NE}_{1}$ has been reportedly greater for diets containing high moisture corn than for diets containing dry corn (Wilkerson et al., 1997), grazing dairy cows supplemented with either high moisture corn, coarsely ground corn, or finely ground corn resulted in similar lactation performances (Soriano et al., 2000). Mid-lactation (107 DIM) Holsteins grazing an orchardgrass-based pasture were supplemented with either high moisture corn (6.0 vs. $4.0 \mathrm{~kg}$ $\mathrm{DM})$, coarsely ground corn $(6.0 \mathrm{~kg} \mathrm{DM})$, or finely ground corn $(6.0 \mathrm{~kg} \mathrm{DM})$ during a 10 week study. Average daily milk, milk fat, and milk protein yields were similar regardless of amounts and forms of corn grain tested, and averaged $30.3 \mathrm{~kg}, 953 \mathrm{~g}$, and $878 \mathrm{~g}$, respectively (Soriano et al., 2000). Similarly, the effects of harvesting and processing methods on lactation performance of grazing dairy cows were also evaluated by Wu et al. (2001), but at higher supplementation levels. Late lactation (247 DIM) dairy cows grazing a permanent native pasture were daily supplemented with $9.0 \mathrm{~kg}$ of either cracked dry corn or ground, high moisture corn during a 13-week study. Although daily milk yield was greater for high moisture than dry corn (22.9 vs. $20.5 \mathrm{~kg}, P=0.05$, respectively), $3.5 \% \mathrm{FCM}$, milk fat and milk protein yields were similar between dietary treatments $(22.1$ vs. $21.4 \mathrm{~kg}, 748$ vs. $763 \mathrm{~g}$, and 770 vs. $682 \mathrm{~g}$, respectively).

The use of supplements such as steam-flaked corn and nonforage fiber for grazing dairy cows was evaluated in two experiments by Delahoy et al. (2003). In experiment 1, late lactation (216 DIM) Holsteins grazing an orchardgrass-based pasture were supplemented with cracked corn or steam-flaked corn at a rate of $1 \mathrm{~kg}$ per $4 \mathrm{~kg}$ milk. Daily milk, milk fat 
and protein productions were similar for both corn processing methods and averaged $24.3 \mathrm{~kg}$, $880 \mathrm{~g}$, and $790 \mathrm{~g}$, respectively. In experiment 2, mid-lactation (182 DIM) Holsteins grazing the same pasture as described previously were fed ground corn $(85 \%$ ground corn plus protein, vitamins and minerals) or a nonforage fiber-based supplement (35\% ground corn, $18 \%$ beet pulp, $18 \%$ soy hulls, $8 \%$ wheat middlings, plus protein, vitamins and minerals) at 1 kg per $4 \mathrm{~kg}$ milk. Similarly, daily milk, milk fat and protein productions remained unaffected by supplementation sources and averaged $27.5 \mathrm{~kg}, 1,065 \mathrm{~g}$, and $955 \mathrm{~g}$, respectively (Delahoy et al., 2003).

Ration balancing becomes extremely challenging because measurement of DM and nutrient concentration of grasses consumed by cows is difficult, even with periodic sampling of the pasture (Hanson et al., 1998). A 24-week study by Hoffman et al. (1993) evaluated the effects of varying pasture composition and concentrate supplementation on lactation performance. Early lactating (82 DIM) Holsteins grazing an orchardgrass-based pasture were supplemented daily with either a) $1 \mathrm{~kg}$ DM of a corn-based concentrate per $3 \mathrm{~kg}$ of milk produced, averaging $8.2 \mathrm{~kg}$ DM per cow; b) $1 \mathrm{~kg}$ of concentrate per $5 \mathrm{~kg}$ milk (during the first 4 weeks of the study) or $4 \mathrm{~kg}$ milk produced (weeks 5 to 24 , due to lower pasture availability), averaging $5.7 \mathrm{~kg}$ DM per cow; or c) same amounts of concentrate offered as treatment $\mathrm{b}$ but reformulated biweekly based on $\mathrm{CP}$ and $\mathrm{ADF}$ content of the pasture, averaging $5.9 \mathrm{~kg}$ DM per cow. Higher amounts of grain consumed daily $(2.5 \mathrm{~kg}$ DM per cow) fed during the 6-month grazing season did not increase milk production (average daily milk production and 3.5\% FCM of 24.7, 23.2, and 24.1; and 25.3, 24.8, and $24.9 \mathrm{~kg}$ for treatments $\mathrm{a}, \mathrm{b}$, and $\mathrm{c}$, respectively) but resulted in higher protein yields (average daily milk protein yields of 760 vs. $720 \mathrm{~g}$ for treatment a vs. b and c, respectively, $P<0.05$ ) (Hoffman 
et al., 1993).

Lush pastures exhibit varying levels of $\mathrm{CP}$ content throughout the grazing season and are generally high in rumen-degradable protein (RDP; Wu et al., 2001). Studies evaluating grain supplements varying in protein concentration and amounts (Jones-Endsley et al., 1997; McCormick et al., 2001) and rumen-undegradable protein (RUP) content (Hongerholt and Muller, 1998; McCormick et al., 2001) fed to high-producing dairy cows grazing quality pastures have been reported. Increasing protein concentration (12 vs. $16 \% \mathrm{CP}, \mathrm{DM}$ basis) and daily amounts offered (6.4 vs. $9.6 \mathrm{~kg} \mathrm{DM})$ of a corn/soybean hulls-based concentrate resulted in similar levels of daily pasture DMI (11.3 vs. 12.9, and 12.5 vs. $11.7 \mathrm{~kg} \mathrm{DM})$ but increased levels of total DMI (18.3 vs. $19.9 \mathrm{~kg}$ DM, $P=0.1$; and 18.1 vs. $20.1 \mathrm{~kg} \mathrm{DM}, P=$ 0.03 ; for treatments 12 vs. $16 \% \mathrm{CP}$ and 6.4 vs. $9.6 \mathrm{~kg}$ DM, respectively) (Jones-Endsley et al., 1997). Daily milk fat and milk protein yields were not affected by CP in the supplement or the amount of supplement offered, and averaged 763 and $698 \mathrm{~g}$, respectively. Although the supply and digestion of nutrients in a grazing situation could be improved by increasing $\mathrm{CP}$ concentration or amount of supplement offered, the impact on milk produced and milk components was relatively small (Jones-Endsley et al., 1997). Similarly, increasing CP concentration of a grain supplement (fed at a rate of $\sim 1.0 \mathrm{~kg}$ concentrate per $3.0 \mathrm{~kg}$ milk) did not affect milk yield of Holstein cows grazing a vegetative annual ryegrass/oat (Avena sativa) mixed pasture, suggesting that energy deprivation, and not $\mathrm{CP}$, may have been the main nutritional constraint for high-producing dairy cows grazing lush pastures (McCormick et al., 2001).

A supplemental grain mixture with a high RUP content did not alter milk yield of high-producing dairy cows offered grazed pasture as the sole forage source (Hongerholt and 
Muller, 1998). An 8-week study by Hongerholt and Muller (1998) evaluated supplements differing in RUP concentration using early lactation (68 DIM) Holsteins that grazed a predominantly orchardgrass pasture. An animal protein blend plus corn gluten meal, and soybean meal provided the protein for the high RUP ( $62.3 \%$ of CP) and low RUP ( $47.0 \%$ of CP) grain mixtures, respectively. Pasture, high RUP, and low RUP grain mixtures averaged $25.6 \%$ CP (4.0\% of CP was RUP), $13.7 \% \mathrm{CP}$, and $14.7 \% \mathrm{CP}$, respectively. Total diets averaged 29.1 and $26.2 \%$ of $\mathrm{CP}$ as RUP for diets containing the high and low RUP grain mixtures, respectively. Total daily DMI were 20.9 and $19.9 \mathrm{~kg}$ for cows fed high and low RUP concentrates, respectively. Concentrates were offered daily at $1 \mathrm{~kg}$ per $4 \mathrm{~kg}$ milk and averaged $8.9 \mathrm{~kg} / \mathrm{cow}$. Average daily milk, milk fat, and milk protein yields ( $35.5 \mathrm{vs.} 34.2 \mathrm{~kg}$; 1,160 vs. $1,200 \mathrm{~g}$; and 1,010 vs. $980 \mathrm{~g}$ for high and low RUP, respectively) were not affected by diets differing in RUP concentration (Hongerholt and Muller, 1998). Although it could be argued that dietary treatments did not differ to a great extent in RUP concentration, additional RUP $(16.2 \% \mathrm{CP}, 66.7 \%$ of $\mathrm{CP}$ as RUP) did not increase $\mathrm{FCM}$ production above that produced by supplementing moderate $\mathrm{CP}$ concentrates $(16.6 \% \mathrm{CP}, 36.7 \%$ of $\mathrm{CP}$ as RUP) for early lactating Holstein cows (McCormick et al., 2001).

Among the various factors that affect pasture DMI are stocking rate, pre-grazing pasture biomass, and pasture allowance, and all have received the most attention in recent U.S. dairy grazing research. Stocking rate, defined as the number of animal units per unit of land area (cows/ha) is a key component in determining productivity per cow of grazing systems (Fales et al., 1995). A 24-week study by Holden et al. (1994a) examined the effects different stocking rates had on pasture and total DMI, cow performance, and pasture nutrient composition and availability. Mid-lactating (133 DIM) Holsteins grazed an orchardgrass- 
based pasture at stocking rates of 2.5 or 3.9 cows per ha and were supplemented daily with 1 $\mathrm{kg}$ DM of a corn-based concentrate per $5 \mathrm{~kg}$ of milk produced. Total daily DMI increased from $21.3 \mathrm{~kg}$ in early spring (measurement date April 30) to $22.4 \mathrm{~kg}$ in late spring (May 28), decreasing thereafter as lactation progressed. Daily pasture DMI ranged from 11.6 (July 30) to $15.6 \mathrm{~kg}$ (September 24) and 4\% FCM ranged from 36.0 (April 30) to $14.9 \mathrm{~kg}$ (September 24). Interestingly, no differences in nutrient composition of the pasture and animal performance measures were reported between stocking rates (Holden et al., 1994a), suggesting that pasture nutrient composition was adequate for maintaining high to moderate levels of milk production even at the high stocking rate.

The effect of pasture allowance (PA), defined as the daily amount of pasture offered per cow $(\mathrm{kg} \mathrm{DM} / \mathrm{cow} / \mathrm{d})$ on pasture DMI of high-producing dairy cows has recently been addressed (Bargo et al, 2002a). Daily pasture DMI of mid-lactation (101 DIM) Holsteins grazing an orchardgrass-based pasture as their sole diet were 17.5 and $20.6 \mathrm{~kg}$ at low PA (26.7 kg DM/cow/d) and high PA (48.9 kg DM/cow/d), respectively. Corn-based concentrate supplementation ( $1 \mathrm{~kg} / 4 \mathrm{~kg}$ milk) decreased daily pasture DMI $2.0 \mathrm{~kg}$ at the low PA and 4.4 $\mathrm{kg}$ at the high PA. Total daily DMI of supplemented diets averaged $24.4 \mathrm{~kg}$. Daily milk production of both supplemented treatments averaged $29.8 \mathrm{~kg}$, but was increased with higher PA in the diets that remained unsupplemented (19.1 vs. $22.2 \mathrm{~kg}$ milk for low vs. high PA, respectively). In a similar fashion, daily milk fat and milk protein yields averaged 970 and $895 \mathrm{~g}$ for both supplemented diets, respectively, but were increased from 740 to $840 \mathrm{~g}$ milk fat $(P<0.05)$; and from 550 to $640 \mathrm{~g}$ milk protein $(P<0.05)$ for the low vs. high PA treatments (Bargo et al., 2002a). Pre-grazing herbage mass for the low and high PA treatments were 2,712 and 2,809 $\mathrm{kg} \mathrm{DM} / \mathrm{ha}$, respectively; and post-grazing herbage mass for 
the low and high PA treatments were 1,013 and 1,575 kg DM/ha, respectively. Accordingly, harvesting efficiencies were 62 and $42 \%$ for the low and high PA treatments (Bargo et al., 2002a).

\section{Performance and dry matter intake of cows fed pasture or pasture-based diets vs. total mixed rations}

Confinement systems that feed TMR allow for the blending of known amounts of forages and concentrates with relatively stable nutritive values, resulting in nutritionally balanced rations. In the U.S., current average milk production for all cows on performance testing programs is almost 9,000 kg milk per cow (National Agricultural Statistics Service, 2006). Throughout their lactations, these cows are typically fed 3,000 to $3,200 \mathrm{~kg}$ grain per cow per year with approximately $40 \%$ and $45 \%$ of the total DMI and $\mathrm{NE}_{1}$ obtained from grains and concentrates (Muller and Fales, 1998). Conversely, the amount and quality of pasture available in grazing systems varies throughout the season and are strongly influenced by an assortment of factors. These include, among others, botanical composition (i.e. grasses and legumes present), weather conditions, fertilization or soil nutrient program, in addition to a number of management decisions (Muller and Fales, 1998).

Some of the studies cited earlier reported a rapid reduction in milk production when cows were moved from TMR to pasture (Hoffman et al., 1993; Jones-Endsley et al., 1997; Wu et al., 2001; Bargo et al., 2002a). Although it had been reported earlier that dairy farmers who transition from confinement feeding to intensive grazing often find that mean herd milk production declines, on average, by 3 to $5 \%$ (Hanson et al., 1998), the reduction in milk production from those studies averaged $24 \%$ and ranged from 18 to $29 \%$. Those rapid reductions in milk production were observed during the $1^{\text {st }} \mathrm{wk}$ (Wu et al., 2001), $2^{\text {nd }} \mathrm{wk}$ 
(Jones-Endsley et al., 1997; Bargo et al., 2002b), and $8^{\text {th }}$ wk (Hoffman et al., 1993) after changing from confinement to pasture. However, a limited number of studies conducted in the Eastern U.S. have compared animal performance under a wide range of feeding strategies including pasture or pasture-based diets vs. TMR diets (Kolver and Muller, 1998; Tucker et al., 2001; Bargo et al., 2002b; White et al., 2002; Fontaneli et al., 2005). In addition, there is limited published information on feeding systems that combine pasture and TMR feeding systems (Soriano et al., 2001; Bargo et al., 2002b).

Long-term, full lactation comparative studies of pasture and confinement systems have been performed in the Eastern U.S. recently (White et al., 2002; Fontaneli et al., 2005). In a four-year study, White et al. (2002) compared the milk and milk components production for the entire lactation of Holstein and Jersey cows fed a TMR or a pasture-based diet supplemented with concentrate and hay or silage. Cows grazed orchardgrass- and tall fescue-based pastures, and winter annuals such as rye (Secale cereale) and annual ryegrass (Lolium multiflorum) during the winter and spring and crabgrass (Digitaria sanguinalis) and a sorghum-sudan hybrid (Sorghum bicolor) during the summer. Cows on pasture, supplemented daily with 6.9 or $8.1 \mathrm{~kg}$ DM of a corn-based concentrate (spring- and fallcalving grazing groups, respectively) produced $11.1 \%$ less milk than cows fed a nutritionally-balanced TMR (White et al., 2002).

A recent, 37-week study conducted in Florida compared productive responses of lactating dairy cows managed under two different pasture-based systems with those of a confinement-type feeding system (Fontaneli et al., 2005). Holsteins were assigned at calving to one of three feeding/management systems: 1) a mixture of rye, annual ryegrass, crimson clover (Trifolium incarnatum) and red clover (Trifolium pratense) grazed during winter and 
spring; and pearl millet (Pennisetum glaucum) grazed during the summer and fall 2) a rye/ryegrass mixture grazed during winter and spring; and bermudagrass (Cynodon spp.) grazed during the summer and fall 3) a traditional free-stall housing system. Cows assigned to grazing systems were supplemented with winter concentrates (containing $29.6 \%$ hominy, $15.0 \%$ citrus pulp, $19.2 \%$ whole cottonseed, and $22.5 \%$ soybean hulls) and summer concentrates $(26.6 \%$ hominy, $15.0 \%$ citrus pulp, $19.2 \%$ whole cottonseed, and $22.5 \%$ soybean hulls) offered at rates of $1 \mathrm{~kg}$ per 2.5 and $2.0 \mathrm{~kg}$ milk during the winter and summer, respectively. Total daily DMI for cows on pasture averaged 24.7 and $19.0 \mathrm{~kg}$ during the winter and summer, respectively. Daily DMI for cows fed a TMR was $23.6 \mathrm{~kg}$, supporting levels of milk production that were $19 \%$ greater than those on pasture systems (29.8 vs. 25.1 $\mathrm{kg}$ milk/d) over the duration of the study (Fontaneli et al., 2005).

A 10-week study by Tucker et al. (2001) compared the effects of two feeding systems, including unsupplemented grazing and TMR feeding, on animal performance. Midto late-lactation Holsteins and Jerseys grazed annual ryegrass as their sole diet or were fed a corn silage-based TMR. Daily DMI was reported weekly and ranged from 18.7 to $21.5 \mathrm{~kg}$ for the TMR group; and 16.2 to $17.2 \mathrm{~kg}$ for the grazing group. Average daily milk production by cows fed TMR ranged from 22.5 to $27.2 \mathrm{~kg}$, while pastured cows declined from 26.6 to $15.9 \mathrm{~kg}$ as lactation progressed (Tucker et al., 2001).

A 21-wk study by Bargo et al. (2002b) compared the effects of three feeding systems that combined pasture and TMR on animal performance. Mid-lactation (109 DIM) Holsteins were assigned to one of the following feeding systems: 1) pasture plus $8.7 \mathrm{~kg}$ DM of a cornbased (59.6\% ground corn, 20.7\% wheat midds) concentrate 2) pasture plus TMR (PMR) and 3) a corn silage-based TMR. Total daily DMI for the respective treatments were 21.6 (12.9 
$\mathrm{kg}$ from pasture), 25.2 (7.5 $\mathrm{kg} \mathrm{DM}$ from pasture), and $26.7 \mathrm{~kg}$, supporting daily milk production of $28.5,32.0$, and $38.1 \mathrm{~kg}(P<0.01)$, respectively. Daily milk fat and protein yields were $890,1,060$, and $1,240 \mathrm{~g}$ milk fat $(P<0.01)$ and 790, 930, and 1,130 g milk protein $(P<0.01)$ for cows on pasture plus concentrate, PMR, and TMR, respectively (Bargo et al., 2002b).

Previously, a six-week study was conducted to examine performance of lactating Holsteins fed TMR compared to ad libitum offering of TMR during half of the day and grazing quality pasture during the other half of the day (Soriano et al., 2001). Mid-lactation (185 DIM) Holsteins were assigned to an all-TMR diet (34.6\% alfalfa silage, 11.8 corn silage, $15.9 \%$ high moisture corn, $19.3 \%$ barley; treatment TMR); or to TMR offered in the morning with afternoon access to pasture (treatment afternoon pasture); or to TMR offered in the afternoon with morning access to pasture (treatment morning pasture). Cows assigned to pasture treatments had access to a predominantly orchardgrass/Kentucky bluegrass pasture during 8 hours a day. Daily TMR intakes for treatments TMR, afternoon pasture, and morning pasture were $26.6,17.5$, and $20.3 \mathrm{~kg}$ DM $(P<0.01)$, respectively. Because daily $3.5 \% \mathrm{FCM}$ (an average of $27.7 \mathrm{~kg}$ ), BW, and BW changes (an average of $25.7 \mathrm{~kg}$ ) were similar for all three treatments, it was assumed that cows who spent less time in confinement but with access to grazing compensated for lower TMR intake to equal the same total DMI. Based on this assumption, cows on the afternoon pasture and morning pasture treatments consumed an average of 9.1 and $6.3 \mathrm{~kg} \mathrm{DM} / \mathrm{d}$ for the length of the study (Soriano et al., 2001).

\section{ESTIMATING DRY MATTER INTAKE OF GRAZING COWS}

Intake is the single most important component driving performance by grazing 
ruminants. Compared to situations where confinement-type diets are fed, obtaining intake measurements of grazing cows requires the use of an indirect method, which is difficult and measurements are less accurate (Curran and Holmes, 1970). In addition to animal variability, pasture palatability, pasture allowance, and pasture selection complicate such measurements, and the process becomes an inherently complex one (Burns et al., 1994; Vasquez and Smith, 2000). Extensive reviews on different aspects of estimating DMI with grazing cows, including approaches, methods or techniques, have been published (Reid, 1956; Leaver, 1982; Poppi et al., 1987; Meijs et al., 1982; Minson, 1990; Burns et al., 1994; Burns and Sollenberger, 2002; Lippke, 2002; Hodgson, 2004). Many of the above aspects are beyond the scope of this review, but a brief background is presented on approaches, techniques, and their comparisons for estimating forage intake of lactating dairy cows on pasture.

Techniques may be classified as pasture- or animal-based (Meijs et al., 1982). Pasture-based techniques estimate DMI by difference between pasture offered (i.e. pregrazing herbage biomass) and pasture refused (i.e. post-grazing herbage biomass). Advantages and disadvantages of pasture-based techniques have been thoroughly discussed (Meijs et al., 1982; t'Mannetje, 2000; Lantinga et al., 2004). Pasture biomass can be a difficult pasture variable to estimate (Webby and Pengelly, 1986). In addition to being an integral part of pasture-based techniques to estimate pasture DMI, the ability to accurately measure pasture biomass is essential to calculate forage availability, elaborate feed budgets, and adjust results for appropriate stocking rates for grazing. Pasture mass is usually estimated using clipping techniques either cutting to ground level (Burns et al., 1989) or to a specific stubble height (i.e. $5 \mathrm{~cm}$ ). A number of indirect, non-destructive methods have been employed to estimate pasture biomass (Harmoney et al., 1997; Sanderson et al., 2001), 
however the rising plate meter (a measure of canopy density that combines canopy height and ground cover; Earle and McGowan, 1979) remains to be the one most widely used. Regression relationships are established between prediction and referral methods (i.e. using clipped and dried samples from known areas, Baker et al., 1981). Overestimating (assuming that all forage removed is a consequence of cow removal by grazing) and underestimating (sward growth between pre- and post-grazing clippings) DMI, in addition to intensive sampling, are serious limitations to the application of pasture-based techniques (Fisher, 1994).

Animal-based techniques for estimating DMI in grazing trials makes use of individual cows as experimental units. The most common animal-based technique used is based on the estimation of fecal quantities excreted and diet digestibility, with the aid of internal (endogenous to the feedstuff) or external (added to the feedstuff or dosed separately to the animal) markers (Le Du and Penning, 1982; Peyraud, 1998). Markers can be administered as a single, large pulse at the beginning of a trial, in uniform daily pulses, or from controlled release devices that are continually active throughout the trial (Lippke, 2002). The estimation of DMI is based on the following equation: DMI = fecal output / (1 digestibility of the diet), provided accurate estimates of fecal output can be obtained from fecal samples that are representative of total excretion (Sollenberger and Cherney, 1995). Fecal production is estimated using external markers, with chromium oxide being the most common marker used (Lippke, 2002). Although this marker has been known to move separately from undigested particles in the diet resulting in fecal $\mathrm{Cr}_{2} \mathrm{O}_{3}$ concentrations with strong diurnal variations (Ruiz et al., 2001), Peyraud suggested that there is no systematic discrepancy in recovery rate between cows or periods of measurements. Digestibility of the 
diet, in turn, can be determined by laboratory procedures (i.e. modified in vitro DM disappearance methods originally designed by Tilley and Terry, 1963). It is important to note that pasture samples for digestibility analysis must resemble those actually eaten by the cows (Reid, 1956).

The use of alkanes in DMI estimation of grazing cows has become increasingly common. This technique is based on the use of plant cuticular wax alkanes as fecal markers. Indigestible odd-chain alkanes from pasture in combination with orally-administered evenchain alkanes are used to estimate DMI (Mayes et al., 1986; Dove and Mayes, 1991). Although variation in marker recovery has been a distinct disadvantage of this technique, and the content of $n$-alkanes in pastures composed of several species can be quite variable (Malossini et al., 1994), alkane marker techniques have recently been developed that apparently reduce this variation (Lippke, 2002). Alkanes in plant cuticular wax are predominantly of odd carbon chain length in the range of $\mathrm{C}_{25}$ to $\mathrm{C}_{37}$. The rates of recovery from the digestive tract of ruminants appear to be related to chain length, approaching $100 \%$ at $\sim \mathrm{C}_{31}$. Although the fecal recovery of alkanes might not be complete, alkanes of adjacent chain length (i.e. $\mathrm{C}_{32}$ and $\mathrm{C}_{33}$ ) have similar recoveries (Smit et al., 2005). Artificial and naturally occurring alkanes in the range of $\mathrm{C}_{32}$ to $\mathrm{C}_{34}$ offer promise in terms of precision for the estimation of forage digestibility and intake of grazing cows (Lippke, 2002).

Malossini et al. (1996) compared the alkane and chromium oxide techniques for estimating pasture DMI in 18 Brown Swiss cows averaging $21 \mathrm{~kg}$ of $4 \%$ FCM. Cows grazed a predominantly grass alpine pasture and were daily supplemented according to milk production, ranging from 1.5 to $8.0 \mathrm{~kg}$ concentrate. Pasture DMI was estimated using the chromium oxide method dosing twice daily, associated with in vitro OM digestibility; and 
with the $n$-alkane method, using $\mathrm{C}_{31}$ as the internal marker and $\mathrm{C}_{32}$ as the external marker, dosing once daily. The greatest sources of variation for each method were between days for the $n$-alkane (54.6\%), and within days for the chromium oxide method (67.0\%). Assuming a $100 \%$ recovery, the chromium oxide technique overestimated pasture DMI by $5.1 \%$ compared to the $n$-alkane method. It was concluded that pasture DMI was similar between methods if a $95 \%$ recovery was assumed for chromium oxide (Malossini et al., 1996).

A dynamic relationship exists between the pasture and the grazing animal. An accurate estimation of daily pasture DMI can be achieved as the product of grazing time (GT, $\mathrm{min} / \mathrm{d})$ and intake rate, a product of bite rate $(\mathrm{BR}$, bites $/ \mathrm{min})$ and bite mass $(\mathrm{BM}, \mathrm{g} \mathrm{DM})$ (Penning and Rutter, 2004). Sward, animal and environmental factors have reportedly been shown to influence GT, BR, and BM (Pulido and Leaver, 1995). Among the factors of plant origin, sward surface height, pasture allowance, tiller density, tensile strength, and fiber content arise as the most important ones (Penning et al., 1991). Physiological status, stage of lactation, BW, nutritional requirement, and productive capacity are among the most important factors of animal origin (Gibb et al., 1997). Ambient temperature, relative humidity, and rainfall are important environmental factors (Champion, et al., 1994). Regardless of these factors, dairy cows on pasture exhibit three main grazing events or bouts throughout the day, namely at dawn, afternoon, and dusk (Rook and Huckle, 1997) with rumen fill being more likely to play a major role in signaling the termination of the dusk grazing bout compared to the other two bouts (Taweel et al., 2004). In order to satisfy nutritional needs under the circumstances imposed by the sward, management, and the environment, the grazing dairy cow maneuvers by adjusting GT, BR, and BM in addition to chewing rate and intake rate. Compared to GT and BR, BM has the greatest influence on 
pasture DMI (Laca et al., 1992; McGilloway and Mayne, 1996).

Estimation of pasture DMI requiring the use of indirect methods that bear several sources of error (i.e. pre-and post-grazing biomass estimates, external or internal markers, grazing ingestive components, among other) and labor-intensive protocols have led researchers to develop predictive equations based on animal and pasture variables (Caird and Holmes, 1986; Vazquez and Smith, 2000, 2001). Empirical models based on regression equations (Caird and Holmes, 1986; Vazquez and Smith, 2000) and mechanistic approaches including long-term intake regulation (Vazquez and Smith, 2001) have been reported. These models utilize animal variables such as total organic matter (OM) intake, pasture OM intake, concentrate supplementation, BW, BW changes, milk yield, stage of lactation; and pasture variables such as pasture biomass, pasture allowance, pasture NDF concentration and digestibility, legume content, and sward height (Caird and Holmes, 1986; Vazquez and Smith, 2000).

Bargo et al. (2003) used the predictive equations developed by Caird and Holmes (1986), Vazquez and Smith (2000), and NRC (2001) to compare estimates of DMI. Using a data set from Bargo et al. (2002b), total daily DMI predicted by Caird and Holmes (1986) and NRC (2001) were similar to those obtained using $\mathrm{Cr}_{2} \mathrm{O}_{3}(21.2,21.9$, and $21.6 \mathrm{~kg}$, respectively). In comparison, estimation of total daily DMI using the equation developed by Vazquez and Smith $(2000)$ was greater $(24.4 \mathrm{~kg}$ DM, $P<0.05)$ than that obtained using $\mathrm{Cr}_{2} \mathrm{O}_{3}$ (Bargo et al., 2003).

Although the Cornell Net Carbohydrate and Protein System (CNCPS; Fox et al., 1992; Sniffen et al., 1992) under predicted total DMI compared to measured DMI $\left(\mathrm{r}^{2}=0.80\right.$; $13 \%$ bias), the model made realistic predictions of intake and performance after evaluating 
data from 8 grazing and indoor pasture feeding studies (Kolver et al., 1998). Extensive reviews on empirical, mechanistic, and modeling approaches for pasture-based systems have been published (Cherney and Mertens, 1998; McNamara et al., 2000). Although to a lesser degree, other methods that estimate pasture DMI have been used based on differences in animal mass (Horn, 1981; Le Du and Penning, 1982); components of plant waxes other than alkanes (i.e. alkenes; Lippke et al., 2002); a combination of $n$-alkanes and ${ }^{13} \mathrm{C}$ techniques (Garcia et al., 2000) and the use of near infrared spectroscopy (NIRS) systems (Valiente et al., 2004).

According to Hodgson (2004), the main factors affecting the choice of technique for measuring pasture intake during the last two decades have been a) the development of automatic instruments recording different aspects of grazing behavior b) technology developed that allows for an increased number of plant micro constituents (i.e. lipids associated to cuticular waxes) for use as quantitative markers c) an increasing restriction on the use of surgically prepared animals and d) an increasing interest in broad-based ecosystem studies recognizing the need of reliable intake measurements.

Studies comparing different techniques for estimating forage intake of lactating dairy cows on pasture have been reported (Reeves et al., 1996; Macoon et al., 2003; Smit et al., 2005). Macoon et al. (2003) compared the ability of three methods (net energy requirements based on animal performance, the use of a pulse-dose marker, and pasture disappearance from pre- and post-grazing herbage biomass readings) to estimate DMI in lactating dairy cows. During the 12-week study (three continuous 28-d periods), Holstein cows $(\mathrm{n}=32)$ grazing a rye/ryegrass mixed pasture or a ryegrass/crimson clover/red clover mixed pasture at two stocking rates $(2.5$ or 5 cows/ha) were fed two concentrate supplementation rates $(1 \mathrm{~kg}$, 
as fed, per 2.5 or $3.5 \mathrm{~kg}$ of milk produced). For the pulse-dose marker method, chromiummordanted fiber was used as the external marker, and hand-plucked samples representing the grazed portion of the pastures were used as the source of fiber mordanting. Pasture sampling to determine pasture biomass disappearance was conducted weekly throughout the study. Forage biomass estimates were conducted using a $0.25-\mathrm{m}^{2}$ rising plate meter placed randomly at 20 sites. Three selected sites of $0.25 \mathrm{~m}^{2}$ were clipped to a $3-\mathrm{cm}$ height (a height that accounted for trampled herbage) during the first and third week of each $28-\mathrm{d}$ period. The animal performance method used energy requirements that were estimated by computing $\mathrm{NE}_{1}$ requirements that accounted for maintenance, lactation, BW changes, walking, and grazing activities (NRC, 2001). Estimates of pasture DMI by the pasture disappearance method were correlated with the animal performance method $(\mathrm{r}=0.57, P<0.001)$. Also, differences between estimates of DMI from these two methods (ranging from -4.7 to $5.4 \mathrm{~kg} / \mathrm{d}$ ) were smaller than the differences between these methods and the marker method. This indicates that suitable pasture DMI estimates could be derived from either the animal performance or the pasture disappearance method (Macoon et al., 2003).

In a similar fashion, two Australian studies conducted by Reeves et al. (1996) compared the ability of three methods to predict DMI in lactating dairy cows on kikuyu grass (Pennisetum clandestinum). Friesian cows $(\mathrm{n}=42)$ that remained unsupplemented or received 3.0 or $6.0 \mathrm{~kg} / \mathrm{d}$ of a cereal-based concentrate were used to compare a pasture disappearance method using a rising plate meter, and an animal performance method during a 45-d trial (study 1). The rising plate meter was calibrated at 2-week intervals with DM available above a 5-cm stubble height to avoid harvesting stoloniferous material, and postgrazing herbage biomass was determined within 3 days of the pre-grazing estimates. The 
animal performance method was based on the difference between metabolizable energy (ME) supplied by grazing and concentrate supplementation (in vitro OM digestibility) and ME required (Ministry of Agriculture, Fisheries and Food, 1975). Estimates of total DMI by pasture disappearance were lower than those predicted by animal performance at low supplementation levels (12.5 vs. 14.8 , and 10.4 vs. $12.9 \mathrm{~kg} / \mathrm{d}$ for cows fed 0 or $3.0 \mathrm{~kg}$ concentrate, respectively), but were greater for those receiving $6.0 \mathrm{~kg}$ concentrate (10.5 vs. $7.8 \mathrm{~kg} / \mathrm{d})$.

In addition to the two techniques used in study 1, above, a third method based on alkanes to estimate DMI was evaluated in a 12-d comparative trial (study 2). The $\mathrm{C}_{32} / \mathrm{C}_{33}$ was the closest alkane pair used to compare DMI estimations from pasture disappearance and animal performance. Supplementation of concentrates resulted in lower estimates of pasture DMI using the animal performance method (10.4 and $6.5 \mathrm{~kg} / \mathrm{d}$ for cows supplemented with 3.0 or $6.0 \mathrm{~kg}$ concentrate, respectively) compared with the pasture disappearance (15.4 and $12.4 \mathrm{~kg} / \mathrm{d})$ and alkane methods $(10.7$ and $9.2 \mathrm{~kg} / \mathrm{d})$. It was concluded that the alkane method provided adequate estimates of intakes for cows grazing intensively-managed kikuyu pastures, and that the animal performance method provided biologically sound estimates of DMI provided all assumptions (i.e. pasture digestibility and BW changes) are known (Reeves et al., 1996).

A recent study conducted in the Netherlands (Smit et al., 2005) also compared pasture disappearance, animal performance, and the $n$-alkane techniques as predictors of pasture DMI. Holstein Friesian cows $(n=12)$ grazed perennial ryegrass during two consecutive summers. Pre-grazing and post-grazing herbage mass were measured by cutting a minimum of $5 \%$ and $10 \%$ of the total area assigned, respectively. Pasture DMI was also calculated 
from the $\mathrm{NE}_{1}$ requirements of the cows and the NE content of the grass (CVB, 1999a; CVB, 1999b). Both combinations of $C_{32} / C_{31}$ and $C_{32} / C_{33}$ alkanes were examined as potential estimators of DMI. The $n$-alkanes method gave similar estimates of DMI in both years (18.2 and $18.2 \mathrm{~kg} / \mathrm{d}$ in year 1 and 17.2 and $17.5 \mathrm{~kg} / \mathrm{d}$ in year 2 for $\mathrm{C}_{32} / \mathrm{C}_{31}$ and $\mathrm{C}_{32} / \mathrm{C}_{33}$, respectively). Estimates of pasture DMI were $16.2,16.8,18.2$, and $17.2 \mathrm{~kg} / \mathrm{d}$ in year 1 and $18.6,15.3,18.2$, and $17.5 \mathrm{~kg} / \mathrm{d}$ in year 2 for the pasture disappearance, animal performance, $\mathrm{C}_{32} / \mathrm{C}_{31}$, and $\mathrm{C}_{32} / \mathrm{C}_{33}$ alkane techniques, respectively. It was concluded that the n-alkanes techniques were the best estimators of pasture DMI when using individual grazing animals (Smit et al., 2005).

\section{RUMINAL ENVIRONMENT AND DIGESTION OF COWS FED PASTURE OR PASTURE-BASED DIETS VS. TOTAL MIXED RATIONS}

A number of reviews have been published on ruminal function and digestion that have focused on different aspects of the grazing dairy cow (Beever and Siddons, 1986; Buxton and Mertens, 1995; Beever and Thorp, 1997; Clark et al., 1997; Cherney and Mertens, 1998; Klopfenstein et al., 2001; Bargo et al., 2003). However, consideration is given to those articles addressing the Eastern U.S. and that have examined ruminal function (i.e. ruminal $\mathrm{pH}, \mathrm{NH}_{3}-\mathrm{N}, \mathrm{VFA}$, and $\mathrm{CH}_{4}$ ) and digestion of comparative feeding systems including pasture or pasture-based diets and TMR feeding systems.

A variety of approaches addressed quantitative ruminal digestion and nutrient flow to the small intestine resulting from pasture only diets. One such approach evaluated rumen digestion of dairy cows consuming the same forage as grazed pasture, hay, or silage (Holden et al., 1994b). Daily DMI and N intake of non-lactating Holsteins that either grazed a predominantly orchardgrass pasture, or were fed hay or silage from the same pasture, were 
similar across dietary treatments averaging $13.3 \mathrm{~kg}$ DM and $340 \mathrm{~g} / \mathrm{d}$, respectively, but nonfiber carbohydrate (NFC) intake was higher from grazed pasture than from hay or silage (4.0 vs. $2.9 \mathrm{~kg} / \mathrm{d}, P<0.05$, respectively). Chemical composition of feeds showed similar CP (17.1\%), NFC (24.5\%), and ADF (27.8\%) concentrations regardless of forage harvesting and storage methods. Grazed pasture was 7 and 15\% lower in NDF than were silage and hay, respectively, but 40 and $30 \%$ greater in apparent ruminal DM degradability and true DM degradability, respectively, than were silage or hay. Although ruminal $\mathrm{pH}$ did not differ across treatments, ruminal ammonia $\mathrm{N}\left(\mathbf{N H}_{3}-\mathbf{N}\right)$ concentration and total volatile fatty acids (VFA) were higher for grazing cows than those fed hay or silage (13.7 vs. $10.9 \mathrm{mg} / \mathrm{dl}, P<$ 0.05 ; and 131.7 vs. $118.4 \mu \mathrm{mol} / \mathrm{ml}, P<0.05$, respectively). Nitrogen flow $(246.2 \mathrm{~g} / \mathrm{d})$, nonammonia $\mathrm{N}$ (NAN) flow $(232.7 \mathrm{~g} / \mathrm{d})$, and bacterial $\mathrm{N}$ flow $(146.1 \mathrm{~g} / \mathrm{d})$ were similar across treatments. It was concluded that because soluble sugars in pasture contributing to the pool of rapidly-fermenting carbohydrates (hence substrate for VFA synthesis) are more readily available in the rumen of cows on pasture than in cows fed stored forages, the supplementation strategies for cows on pasture should be designed to synchronize protein and carbohydrate in the rumen in order to increase post-ruminal nutrient supply (Holden et al., 1994b).

High producing dairy cows fed a nutritionally balanced TMR typically produce more milk and milk components than those fed pasture-based diets (Kolver and Muller, 1998; Bargo et al., 2002b; Tucker et al., 2001). In addition to decreased levels of intake, the lower lactation performance from pasture-based diets may be related to changes in ruminal fermentation and digestion (Bargo et al., 2002c), although this concept may be challenged to some extent, due primarily to the apparent failure of pasture not always being reflected in 
rumen function (Clark et al., 1997). To aid in this matter, the content of effective NDF (eNDF; Mertens, 2002), the proportion of NDF that stimulates chewing activity leading to enhanced ruminal buffering effects of saliva, is likely to be less than $50 \%$ of the total NDF content of vegetative cool-season grasses (Clark et al., 1997). A high proportion of pasture NDF is readily fermentable, resulting in rapid production of VFA; and the blend of high VFA concentrations and low eNDF are most likely to cause the low rumen $\mathrm{pH}$ measured in pasture-fed cows (Doyle et al., 2005).

Ruminal environments from cows grazing high-quality pastures $(<50 \%$ NDF) supplemented with concentrates are often characterized, in addition to reduced ruminal $\mathrm{pH}(<$ 6.0), by low acetate-to-propionate ratios, high $\mathrm{NH}_{3}-\mathrm{N}$ concentrations, and high rate of passage (Holden et al., 1994b; Bargo et al., 2001). Also, cows grazing high quality pastures fed supplemental energy produce milk with a lower fat concentration in most (Polan et al., 1986; Berzaghi et al., 1996; Reis and Combs, 2000) but not all (Holden et al., 1995; Dhiman et al., 1999) situations, even when the diets fed appear to be adequate in NDF content (NRC, 2001). This indicates that specific recommendations for adequate NDF content of pasturebased diets may be lacking. According to the NRC (2001), decreased milk fat concentration from pasture-based diets can be attributed to reduced salivation, greater quality pastures providing for greater-digestible fiber, and the rapid consumption of grain caused by feeding concentrates twice daily and separated from forage. Conversely, simultaneous consumption of fiber and nonstructural carbohydrates (NSC) from TMR diets allows for increased chewing and salivation, leading to increased ruminal buffering capacity while the NSC fraction is being fermented (NRC, 2001).

Although a number of U.S. studies have previously compared animal performance of 
high-producing dairy cows on TMR vs. pasture-only diets (Kolver and Muller, 1998; Tucker et al., 2001), TMR vs. pasture plus concentrate (White et al., 2002; Fontaneli et al., 2005), and TMR vs. TMR plus pasture (Soriano et al., 2001; Bargo et al., 2002b), only Bargo et al. (2002c) evaluated rumen digestion variables. Supplementing a pasture-based diet with a TMR has resulted in improved lactation performance. This is due to increased total DMI and changes in ruminal fermentation and digestion. These changes occurred mainly through improved ruminal $\mathrm{pH}$ stability and a reduction in $\mathrm{NH}_{3}-\mathrm{N}$ concentration (or increased $\mathrm{N}$ capture) from forage sources that are greater in effective fiber and lower in CP compared to pasture sources (Bargo et al., 2002c).

Rumen-cannulated Holsteins $(\mathrm{n}=6)$ included in a $21-\mathrm{wk}$ study by Bargo et al. (2002b) provided the rumen digestion and fermentation data from feeding three different diets that combined pasture, concentrates, and TMR. Cows were assigned to one of the following feeding systems: 1) a predominantly smooth bromegrass pasture supplemented with $8.8 \mathrm{~kg}$ DM of a corn-based (59.6\% ground corn, $20.7 \%$ wheat midds) concentrate; 2 ) the same pasture plus a corn-silage based TMR (PMR); and 3) TMR (52:48 forage-toconcentrate ratio). For the purpose of this study, it was assumed that because DMI, lactation performance, and BW of cannulated cows exhibited similar trends to those reported from a larger group of cows $(\mathrm{n}=45$; Bargo et al., 2002b), ruminal digestion data could be extrapolated to this larger group.

Cows in the TMR group (26.3 kg DMI) consumed $16 \%$ more total daily DMI than cows in the pasture plus concentrate group $(22.6 \mathrm{~kg})$ and $2 \%$ more than cows in the PMR group $(25.7 \mathrm{~kg})$. Ruminal $\mathrm{pH}$ did not differ across dietary treatments and averaged 5.87, similar to findings reported earlier for high-producing dairy cows fed diets with 
approximately $50 \%$ concentrates $(\mathrm{pH}=5.7$; Satter et al., 1999) and cows consuming fresh grass-legume forage supplemented daily with $10 \mathrm{~kg}$ of corn grain $(\mathrm{pH}=5.79$; Reis et al., 2001). Also, total VFA concentrations were similar across treatments and averaged 137 $\mu \mathrm{mol} / \mathrm{ml}$, maintaining similar VFA molar proportions for the three main VFA (averaging 63.1, 20.6, and $12.0 \mathrm{~mol} / 100 \mathrm{~mol}$ for acetate, propionate, and butyrate, respectively) and acetate-to-propionate ratios (3.11:1) (Bargo et al., 2002c). In contrast, ruminal $\mathrm{NH}_{3}-\mathrm{N}$ concentration was greater for the pasture plus concentrate group compared to both PMR and TMR groups (19.9 vs. $10.2 \mathrm{mg} / \mathrm{dl}, P<0.05$ ), results that are consistent with increased plasma urea nitrogen (PUN) and milk urea nitrogen (MUN) from pasture plus concentrate (17.2, 13.8, and $13.8 \mathrm{mg} / \mathrm{dl} \mathrm{PUN}$; and 14.9, 12.0, and $10.6 \mathrm{mg} / \mathrm{dl} \mathrm{MUN}$ for treatments pasture plus concentrate, PMR, and TMR, respectively). Similar ruminal $\mathrm{NH}_{3}-\mathrm{N}$ concentrations were reported for cows consuming fresh grass-legume forage supplemented daily with $10 \mathrm{~kg}$ of corn grain (16.9 mg/dl; Reis et al., 2001).

In order to characterize the feeds and feed interactions, in situ DM, CP, and NDF ruminal digestion data of the pasture, concentrate, and TMR treatments were reported (Bargo et al., 2002c). The potential disappearance of pasture DM was calculated as A $+B^{*}\left[1-\mathrm{e}^{-\mathrm{kd} * t}\right]$ where $\mathbf{A}=$ soluble fraction, $\% ; \mathbf{B}=$ potentially degradable fraction, $\% ; \mathbf{k d}=$ fractional degradation rate, $\% / \mathrm{h}$; and $\mathbf{t}=$ time, $\mathrm{h}$; using a nylon bag method (Orskov and MacDonald, 1979). This value was reduced $(85.5$ vs. $82.3 \% ; P<0.05)$ by including TMR in the diet as opposed to concentrate. Accordingly, the potential disappearance of pasture NDF was reduced (82.1 vs. $75.0 \%$ ) for the PMR group compared to pasture plus concentrate, suggesting possible associative effects in the rumen for the PMR group, in accordance with previous reports where NDF digestion was reduced by incorporating TMR to pasture-based 
diets (Dixon and Stockdale, 1999).

Utilization of RDP from pasture is affected, among other factors, by the time at which supplemental energy sources are fed to grazing cows (Kolver et al., 1998; Vaughan et al., 2002). Using BUN as an indicator of ruminal $\mathrm{N}$ capture (due to its positive association with ruminal ammonia concentrations; DePeters and Ferguson, 1992), lactating dairy cows fed a corn-silage based TMR 2.5 hours before grazing maintained lower BUN across a 7-h period during which blood samples were collected (Vaughan et al., 2002). Conversely, cows that consumed the TMR immediately after grazing maintained the greatest BUN, with intermediate BUN in cows fed TMR 1 hour before grazing. Although $\mathrm{N}$ capture from grazing a rye pasture was improved by feeding TMR before grazing, milk production and milk components were similar for all TMR feeding times (Vaughan et al., 2002).

Attempting to predict constraints from pasture-based feeding systems, a comparison of several performance and ruminal fermentation and digestion variables of dairy cows offered New Zealand-type spring or summer cool-season pastures vs. a TMR was performed (Clark et al., 1997). For simulation purposes, Friesian cows of equally high genetic merit at two BW (small, $450 \mathrm{~kg} \mathrm{BW}$; and large, $650 \mathrm{~kg} \mathrm{BW}$ ) were used to predict requirements and production using a ruminant nutrition model (CNCPS; Fox et al., 1992). Early lactation (60 DIM) and late lactation (200 DIM) cows were used to predict DMI and ruminal digestion variables from spring pasture vs. TMR and summer pasture vs. TMR, respectively. Predictions of DMI from cows grazing a spring pasture (19.5\% CP, $2.7 \mathrm{Mcal}$ ME/kg DM) vs. TMR (25\% alfalfa hay, $25 \%$ corn silage, $31.5 \%$ crushed barley, $15 \%$ soybean meal, $3.5 \%$ fish meal) were identical. Likewise, predictions of DMI from cows grazing a summer pasture (20.0\% CP, 2.3 Mcal ME/kg DM) vs. TMR were identical. Although no constraints to 
grazing (i.e. pasture allowance) were assumed, pasture DMI representing 3.87\% BW (17.4 $\mathrm{kg}$ for a $450-\mathrm{kg}$ cow) and $3.71 \% \mathrm{BW}(24.1 \mathrm{~kg}$ for a $650-\mathrm{kg}$ cow) seemed unreasonably high (Mayne and Wright, 1988). Metabolizable protein (MP; allowing for 36.3 and $50.7 \mathrm{~kg}$ milk for 450- and 650-kg cows, respectively) and amino acid (AA; allowing for 35.5 and $49.1 \mathrm{~kg}$ milk for 450 - and $650-\mathrm{kg}$ cows, respectively) supply to the small intestine did not limit milk production from spring pasture- and TMR-fed cows (Clark et al., 1997).

The efficiency of microbial protein production ( $34 \mathrm{~g}$ microbial $\mathrm{N} / \mathrm{kg}$ ruminally degraded $\mathrm{OM}$, assuming that $65 \%$ of $\mathrm{OM}$ intake was ruminally digested) exceeded requirements by $\sim 130 \%$ and was similar to that reported by Carruthers et al. (1996) who reported microbial efficiencies of 31 to $34 \mathrm{~g}$ microbial $\mathrm{N} / \mathrm{kg}$ ruminally degraded $\mathrm{OM}$ from perennial ryegrass/white clover mixtures. Conversely, the efficiency of microbial protein production from cows fed a summer pasture was reduced to $22 \mathrm{~g}$ microbial $\mathrm{N} / \mathrm{kg}$ ruminally degraded OM, in agreement with Carruthers et al. (1996) who reported microbial efficiencies of 20 to $24 \mathrm{~g}$ microbial N/kg ruminally degraded OM. Although MP supply could potentially support a daily milk production of $23.9 \mathrm{~kg}$, the shortage of AA supply could only support a daily milk production of $15.5 \mathrm{~kg}$. This indicates that the AA supply was the most limiting nutrient in the current situation (Clark et al., 1997). Unfortunately, grazed pasture is not a homogeneous feed. Typically, spring pastures are of high quality, but as the grazing season progresses, a combination of poor utilization, changes in plant structure associated with reproductive growth, the effects of higher temperatures and moisture deficits, among others, deteriorate such quality. The major constraints for summer pastures identified by this simulation exercise were a relatively high proportion of NDF (56\%, DM basis) combined with a high concentration of soluble protein (SP; $23 \%$ of CP) and low NSC (13.3\%, DM 
basis), leading to low metabolizable energy levels, poor fermentation, and decreased microbial protein yield (Clark et al., 1997).

\section{RUMINAL LIPID METABOLISM AND MILK LONG-CHAIN FATTY ACID COMPOSITION OF GRAZING COWS}

\section{Overview of Ruminal lipid metabolism}

Microbial activity extensively modifies plant lipids. Briefly, a number of metabolic processes take place in the rumen including complete hydrolysis of acylglycerols, mainly triglycerides, isomerization, biohydrogenation of unsaturated fatty acids (FA), and phospholipid synthesis by microbial biomass (Harvatine and Allen, 2004). A rapid hydrolysis is followed by biohydrogenation of unsaturated FA. Biohydrogenation, the process by which ruminal microorganisms transform unsaturated FA via hydrogen addition by microbial enzymes, is traditionally reported as the proportion of double bonds removed in the rumen (Wu et al., 1991) and plays a relatively minor role as a source of hydrogen sink, approximately 1 to $2 \%$ of metabolic hydrogen is used for this purpose (Van Soest, 1994). Microbial lipases hydrolyze acylglycerols completely to free FA and glycerol. The latter is fermented rapidly yielding propionic acid as a major end product (Van Soest, 1994). Hydrolysis of esterified plant lipids is accomplished by a variety of microbial lipases, galactosidases, and phospholipases including phospholipase A, phospholipase C, lysophospholipase, and phosphodiesterase (Jenkins, 1993). Although a wide variety of ruminal bacteria have esterase activity, including approximately 30 strains of Butyrivibrio fibrisolvens, only a few bacteria can hydrolyze long-chain fatty acids (Hespell and O'BryanShah, 1988).

Because the initial step in biohydrogenation is an isomerization reaction that requires 
exposure to a free carboxyl group, lipolysis is a required step for biohydrogenation (Wu et al., 1991). The isomerization reaction converts the cis-12 double bond in unsaturated FA to a trans-11 isomer. Then, the cis-9 bond in $\mathrm{C}_{18: 2}$ is reduced by microbial reductase (Jenkins, 1993). Linoleate isomerase, a bacterial cell membrane-bound enzyme, is responsible for forming conjugated double bonds from the cis-9, cis-12 double bond structure of linoleic acid in addition to $\alpha$ - and $\gamma$-linolenic acids (Bauman et al., 1999). The second reaction is a reduction in which cis-9, trans-11 $\mathrm{C}_{18: 2}$ is converted to trans-11 $\mathrm{C}_{18: 1}$. Because the subsequent hydrogenation of trans-11 $\mathrm{C}_{18: 1}$ to $\mathrm{C}_{18: 0}$ occurs less rapidly than the first hydrogenation, it has been suggested that the trans- $11 \mathrm{C}_{18: 1}$ reduction is rate-limiting in the biohydrogenation sequence of unsaturated $\mathrm{C}_{18} \mathrm{FA}$ (Bauman et al., 1999).

The major microbial transformations in the rumen are biohydrogenation of $\mathrm{C}_{18: 3}$ and

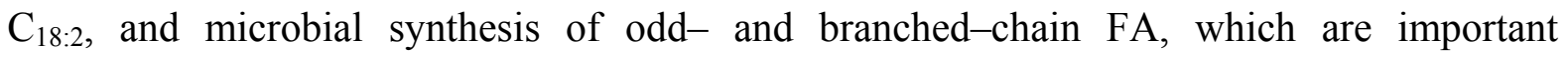
components of microbial lipids (Kim et al., 2005). Recent work by Cabrita et al. (2003) suggested that milk odd-chain FA may aid in rumen function assessment including an overall description of microbial populations and substrate presence, although this hypothesis needs to be further validated. Ruminal biohydrogenation causes $\mathrm{C}_{18: 0}$ and various isomers of $\mathrm{C}_{18: 1}$ to be the major FA leaving the rumen (NRC, 2001). According to Harvatine and Allen (2004), the degree to which biohydrogenation occurs is determined by a) the pool size of available FA and degree of unsaturation of FA; b) ruminal retention time; and c) bacterial biohydrogenation capacity, a function of the bacterial population and ruminal environment. In addition, the rate at which lipolysis and biohydrogenation occur varies with forage quality, surface area of feed particles reaching the rumen, and structural modifications of the lipid molecule that inhibit microbial isomerization (Jenkins, 1993). 
As described above, most of the unsaturated FA will be converted in the rumen to stearic acid (SA, $\mathrm{C}_{18: 0)}$ ), however small quantities of conjugated linoleic acid, trans-vaccenic acid (tVA, trans-11 $\mathrm{C}_{18: 1}$ ), and other trans-FA flow to the duodenum for subsequent absorption. Free FA and microbial phospholipids account for $\sim 85$ to $90 \%$ and 10 to $15 \%$ of the FA leaving the rumen, respectively (Klusmeyer and Clark, 1991). Because of their hydrophobic nature, FA associate with particulate matter in order to flow to the duodenum (Jenkins, 1993).

\section{Milk long-chain fatty acid composition of grazing cows}

The vast majority of the lipids in milk are triacylglycerides, accounting for 96 to $97 \%$ of the total lipid content of milk, followed by diacyglycerides (2.2\%), phospholipids (1.1\%), and sterols $(0.5 \%)$. The latter is composed primarily by cholesterol, with whole milk containing approximately $15 \mathrm{mg} / \mathrm{dl}$ (Jensen, 2000). Milk fat typically contains a high proportion of saturated FA (approximately 70 to $75 \%$, largely due to microbial biohydrogenation in the rumen) and monounsaturated fatty acids (MUFA; approximately 20 to $25 \%$ ) with small amounts of polyunsaturated FA (PUFA; approximately 5\%) also present (Lock and Shingfield, 2004). Milk fat synthesis involves both mammary de novo synthesis from arterial acetate and $\beta$-hydroxy butyrate, and mammary uptake of preformed triacylglycerides in the form of low density lipoproteins and circulating non-esterified FA (NEFA) (Van Soest, 1994; Beever et al., 1999). Almost all $\mathrm{C}_{4: 0}$ to $\mathrm{C}_{14: 0}$ fatty acids and $\sim 50 \%$ of $\mathrm{C}_{16: 0}$ in milk are derived from de novo fatty acid synthesis (Grummer, 1991). The extensive reliance on acetate and $\beta$-hydroxy butyrate (de novo synthesis) and highly saturated LCFA (originating from rumen biohydrogenation) for milk fat synthesis results in milk fat with a high proportion of saturated FA. Because the mammary gland extracts these 
FA from arterial circulation to synthesize milk fat, the concentration of the various trans-FA in milk is typically a reflection of the efficiency of ruminal biohydrogenation (Herbein et al., 2004).

Fatty acids for milk fat synthesis are derived from the diet plus rumen microorganisms (approximately 400-450 g/kg); from adipose tissues (less than $100 \mathrm{~g} / \mathrm{kg}$ ); and from de novo synthesis in the mammary gland (approximately $500 \mathrm{~g} / \mathrm{kg}$ ) in dairy cows on pasture-based diets (Palmquist and Jenkins, 1980). However, the relative contributions of these sources of fatty acids to milk fat production are highly dependent on feed intake levels, diet composition, and lactation stage (Palmquist, 2001). Significant differences in these factors exist between pasture-based dairy production systems and those based on total mixed ration, leading to differences in milk fat composition between the two systems: high intakes of starch are associated with higher levels of de novo synthesis of fat in the mammary gland, resulting in milk fat with a higher concentration of saturated fatty acids (Walker et al., 2004). Conversely, higher intakes of PUFA from pasture result in higher concentrations of unsaturated fatty acids, particularly oleic $\left(\mathrm{C}_{18: 1 \mathrm{n}} \mathrm{n}\right)$, trans-vaccenic acid, and conjugated linoleic acid (CLA) in milk fat (Bertrand et al., 2004).

The presence of certain atherogenic FA in milk, such as the medium-chain unsaturated FA lauric $\left(\mathrm{C}_{12: 0}\right)$, myristic $\left(\mathrm{C}_{14: 0}\right)$, and palmitic $\left(\mathrm{C}_{16: 0}\right)$ acids, which account for the majority of saturated FA in milk (Dewhurst et al., 2006) remains a matter of concern (Grummer, 1991; Jensen, 2000). Recommendations for a reduction in saturated fat content in the human diet initiated a period of intense research in the early $70 \mathrm{~s}$ to increase the unsaturated fat content of milk fat by altering the way cows are fed (Grummer, 1991; Jenkins and McGuire, 2006). More recently, attention has been directed at manipulating the fatty acid 
composition of milk with a particular emphasis on the conjugated linoleic acid complex of isomers and the $\mathrm{n}-3$ PUFA such as $\alpha$-linolenic acid $\left(\mathrm{C}_{18: 3}\right)$, eicosapentaenoic acid (EPA, $\mathrm{C}_{20: 5}$ ), and docosahexaenoic acid (DHA, $\mathrm{C}_{22: 6}$ ). Alpha-linolenic acid, an essential FA, is found in plant foods including grasses, and EPA and DHA are found predominantly in fish and fish oils (Sinclair et al., 2005). The omega-3 FA have been implicated collectively in reducing the risk of cardiovascular disease in humans (World Health Organization, 2003).

A number of breeding and nutritional strategies have been developed to manipulate milk fat content; however, genetic advances have targeted fat levels whereas nutritional advances have had a measurable effect on fat composition (Lock and Shingfield, 2004). The direct incorporation of preformed FA has long been identified as an opportunity for manipulation of milk FA composition (Beever et al., 1999; Dewhurst et al., 2006).

\section{Milk conjugated linoleic acid and other selected fatty acid concentrations of grazing vs.}

\section{nongrazing dairy cows}

Milk fat is a major dietary source of CLA for which an impressive list of health promoting biological properties has been reported in a variety of biological models (McGuire and McGuire, 1999). In 1935, Booth et al. reported that milk produced during the summer had a greater absorbance at $233 \mathrm{~nm}$, a measurement of CLA concentration, than milk produced during the winter. Three decades later, Riel (1963) reported that summer milk fat, when cows had access to pasture, had more conjugated dienoic acid than winter milk fat (1.46 vs. $0.78 \%$ of total fatty acids, respectively). Parodi (1977) demonstrated that these compounds, that occur at low levels $(<1 \%$ of total FA), largely represented conjugated cis -9 , trans-11 octadecadienoic acid. In 1979, Pariza et al. discovered a group of fatty acids identified as CLA that appeared to be antimutagenic (Pariza et al., 1979; Pariza et al., 1983). 
More recently, CLA has been implicated in inhibiting carcinogenesis (Ha et al., 1987; Ip et al., 1999), preventing atherosclerosis (Lee et al., 1994), improving glucose homeostasis (Houseknecht et al., 1998), and altering nutrient partitioning improving the protein-to-fat ratio (Dougan et al., 1997) in experimental animals.

The mechanism by which CLA exhibits its anticarcinogenic activity remains uncertain (Parodi, 1994; McGuire and McGuire, 1999). Briefly, CLA apparently modulate carcinogenesis by mechanisms that affect different stages of cancer development. Mechanisms of inhibition of carcinogenesis may include reduction of cell proliferation, alterations in the components of the cell cycle and induction of apoptosis (Belury, 2002). Conjugated linoleic acid reportedly acts by modulating the activity of cytochrome $\mathrm{P}_{450}$ (Liew et al., 1995); eicosanoid formation, lipid metabolism and gene expression (Belury, 2002); and reducing the induction of known tumor production indicators (i.e. ornithine decarboxylase and protein kinase C; Parodi, 1994). Some of the anti-carcinogenic properties of CLA may be due to its effective antioxidant properties (Ha et al., 1990) via one or more of these pathways in a tissue-specific fashion (Belury, 2002).

Conjugated linoleic acid, a collective term for more than 20 close relatives or isomers of linoleic acid (LA, $\mathbf{C}_{18: 2} \mathrm{n} 6$ ) is produced from the biohydrogenation of $\mathrm{C}_{18: 2}$ to $\mathrm{C}_{18: 0}$ by $B$. fibrisolvens, a hemicellulose-digesting bacterium found in high numbers when cows are fed forage-based diets (Kepler et al., 1966). Chemical configurations such as cis and trans, when applied to these molecules, describe different isomers. The term 'conjugated' refers to the fact that a single carbon-to-carbon bond is placed separating the two double bonds, whereas most PUFA have two single carbon-to-carbon bonds placed between double bonds. Kepler and Tove (1967) showed that cis-9, trans-11 $\mathrm{C}_{18: 2}$ is formed as the first intermediate of the 
biohydrogenation of linoleic acid by rumen bacteria (i.e. B. fibrisolvens). After the trans-11 bond is formed by microbial isomerase, the cis- 9 bond is reduced and a MUFA (trans-11 $\left.\mathrm{C}_{18: 1}\right)$ is formed. Furthermore, trans $-11 \mathrm{C}_{18: 1}$ can be completely biohydrogenated to stearic acid (Kepler et al., 1971).

Interestingly, ruminal fermentation is not the only source of CLA. Recent research has focused on endogenous synthesis of CLA from ruminally-derived vaccenic acid, a pathway that provides for more than 50\% of the CLA in milk fat (Palmquist, 2001; Peterson et al., 2002). If biohydrogenation is incomplete, some trans $\mathrm{C}_{18: 1}$ can flow from the rumen, absorbed postruminally, and converted to CLA by the $\Delta^{9}$-desaturase of the mammary and adipose tissues (Griinari et al, 2000; Kim et al., 2000). Griinari et al. (2000) demonstrated that an active pathway of endogenous synthesis of CLA is present, accounting for a $31 \%$ increase in the concentration of cis-9, trans-11 CLA in milk fat by infusing trans-11 vaccenic acid postruminally. Other $\Delta^{9}$-desaturase products have been reported in addition to the endogenous synthesis of cis-9, trans-11 CLA (Peterson et al., 2002). The enzyme catalyzes the introduction of a cis-9 double bond in several other FA found in milk fat including, among other, the conversion of $\mathrm{C}_{18: 0}$ to oleic acid (cis-9 $\mathrm{C}_{18: 1}$; Herbein et al., 2004). Product/substrate relationships established from the pairs of FA modified are a suitable indicator of the $\Delta^{9}$-desaturase activity (Bauman and Griinari, 2001).

There are 14 natural isomers of CLA in milk fat (Lock and Bauman, 2004). Although isomers with double bonds have been reported in other positions, such as 8 and 10, and 11 and 13, double bonds of CLA occur mainly at positions 9 and 11, or 10 and 12 (Ha et al., 1987). The major isomer of CLA in milk fat is cis-9, trans-11, which accounts for approximately 70 to $90 \%$ of total CLA (Parodi, 1977; Bauman et al., 1999). Also, of the 
individual isomers of CLA, cis-9, trans-11 has been implicated as the most important isomer in terms of biological activity, most presumably because it is the only isomer incorporated into the phospholipid fraction of tissues of animals fed a mixture of CLA isomers (Ha et al., 1990; Parodi, 1994). The trans-10, cis-12 CLA isomer has been reportedly linked with milk fat depression (Bauman and Griinari, 2001). Although the mechanisms by which trans-10, cis-12 CLA alters lipid metabolism are not fully understood (Baumgard et al., 2002), this CLA isomer has also been specifically linked with a decrease in mice body fat simultaneously increasing lean body mass (Park et al., 1999).

Amounts of biohydrogenation intermediates produced in the rumen influence their concentrations in milk, and the fatty acid profile of dairy diets can have a profound effect on the composition of milk fat. A considerable body of literature has established that milk from grazing cows contains higher proportions of CLA and omega-3 FA compared to those fed conserved forages (Jahreis et al., 1997; Kelly et al., 1998; Dhiman et al., 1999; White et al., 2001; Wijesundera et al., 2003; Stockdale et al., 2003; Loor et al., 2003; Schroeder et al., 2003, 2005). In addition, milk from grazing cows contains more trans-FA than milk from cows fed a TMR, due primarily to an increase in the trans- $11 \mathrm{C}_{18: 1}$ concentration (Loor et al., 2003). Although numerous research studies indicate that CLA concentration in milk fat may be routinely increased from 5- to 10-fold (Palmquist, 2001), pasture-based diets have shown increased CLA concentrations in milk fat that range from approximately 2-(Jahreis et al., 1997; Schroeder et al., 2005) to 5-fold (Dhiman et al., 1999).

Jahreis et al. (1997) reported that cows fed a corn silage-based diet with no access to pasture produced milk with a lower concentration of CLA compared to cows that grazed pasture ( 0.34 vs. $0.80 \%$ of total FA measured, respectively). The authors concluded that the 
high level of unsaturated FA in the grass was responsible for the increase in CLA concentration. Dhiman et al. (1999) fed lactating Holsteins one-third (4.5 kg pasture DMI, actual $28 \%$ of total intake), two-thirds ( $9.0 \mathrm{~kg}$ pasture DMI, actual $60 \%$ of total intake), or their entire diet (14.1 $\mathrm{kg}$ pasture DMI) as pasture, a mix of blue grass, quackgrass, bromegrass, and white clover. Conjugated linoleic acid and $\mathrm{C}_{18: 3}$ concentrations in milk increased linearly as the amount of pasture was increased in the diet $(8.9,14.3$, and $22.1 \mathrm{mg}$ CLA; and 8.1, 14.6, and $20.2 \mathrm{mg} \mathrm{C}_{18: 3} / \mathrm{g}$ milk FA, respectively). Conversely, the proportion of $\mathrm{C}_{18: 2}$ and milk fat yield decreased linearly with increased pasture intake (42.7, 27.1, and $14.0 \mathrm{mg} \mathrm{C} \mathrm{C}_{18: 2} / \mathrm{g}$ milk FA; and $0.86,0.64$, and $0.49 \mathrm{~kg} / \mathrm{d}$ for one third-, two thirds-, and allpasture diets, respectively).

Previously, Kelly et al. (1998) had compared the milk fatty acid composition of cows fed TMR or a pasture-only diet. As the grazing group was gradually adjusted to greater pasture intakes, concentrations of CLA in milk gradually increased. During the final period, when cows on the pasture group were fed a pasture-only diet, average milk CLA concentration was 1.09 vs. $0.46 \%$ of total fatty acids for the total mixed ration group. In a similar fashion to Dhiman et al. (1999), milk fat yield decreased (1.52 vs. $1.10 \mathrm{~kg} / \mathrm{d})$ and milk $\mathrm{C}_{18: 3}$ concentrations increased ( 2.5 vs. $9.5 \mathrm{mg} \mathrm{C} \mathrm{C}_{18: 3} / \mathrm{g}$ milk FA) for the grazing group, while milk fat percentage remained unaffected. However, $\mathrm{C}_{18: 2}$ concentration was reported to be similar ( 26.2 vs. $22.5 \mathrm{mg} \mathrm{C}_{18: 2} / \mathrm{g}$ milk FA for TMR and pasture, respectively) for both diets.

The concentration of cis-9, trans-11 CLA in milk fat from a pasture-based diet (with crabgrass as the main component of the pasture mix and supplemented with $5.5 \mathrm{~kg}$ of a ground corn-based concentrate) were higher than that from a TMR ( 0.72 vs. $0.41 \%$ of total 
fatty acids for Holsteins and 0.59 vs. $0.32 \%$ of total fatty acids for Jerseys, respectively; White et al., 2001). The authors reported both lower fat yields and fat percentages for the pasture-based group. Researchers in Australia also showed that the proportions of cis-9, trans-11 CLA were highest for pasture-only diets when compared with barley-based supplemented diets (Wijesundera et al., 2003; Stockdale et al., 2003). However, the effects of grain supplementation on CLA concentration showed the opposite results in a second experiment by Wijesundera et al. (2003) which was attributed to factors such as quality of the pasture that led to altered pasture intake levels, and lipid mobilization from fat stores associated with the physiological state and energy balance of the cows. Stockdale et al. (2003) also reported that the concentration of cis-9, trans-11 CLA in milk fat and total yield of CLA varied quadratically with the amount of cereal grain-based concentrate fed to cows grazing perennial pasture. In one study, CLA concentration in milk fat decreased from 15.0 to $10.0 \mathrm{mg} / \mathrm{g}$ milk fat in unsupplemented vs. supplemented diets with cereal grain-based concentrates ( $7 \mathrm{~kg} \mathrm{DM} / \mathrm{cow})$, but increased to $14 \mathrm{mg} / \mathrm{g}$ milk fat when the level of supplementation increased to $11 \mathrm{~kg} \mathrm{DM} / \mathrm{cow}$. This response was associated with a reduction in milk fat level at the latter supplementation level. The reduction in the concentration of CLA in milk fat in response to feeding up to $6 \mathrm{~kg}$ DM cereal grain-based supplement/day to cows grazing perennial pasture has been consistent across a number of experiments (Stockdale et al. 2003).

A six-week study by Loor et al. (2003) reported increased concentrations of $\mathrm{C}_{18: 3}$, trans-11 $\mathrm{C}_{18: 1}$ and cis-9, trans-11 CLA in milk fat of cows that had an 8-hour access to pasture compared to confinement-fed cows. Concentrations of $\mathrm{C}_{18: 3}$ and cis-9, trans-11 CLA in milk fat of pastured cows were increased by 50 and $60 \%$ compared with cows fed a 
TMR only ( 8.1 vs. 5.4 and 9.3 vs. $5.8 \mathrm{mg} / \mathrm{g}$ total milk FA, respectively). Schroeder et al. (2003) compared milk CLA concentration from cows fed either pasture plus $6.7 \mathrm{~kg}$ DM of a corn-based concentrate; pasture plus $4.8 \mathrm{~kg}$ DM of a corn-based concentrate and $0.8 \mathrm{~kg}$ of Ca salts of unsaturated FA; and a TMR. Milk CLA concentrations were 1.12, 1.91, and 0.41 g/100 g milk FA, respectively. Although no differences were reported in milk yield (19.9 $\mathrm{kg} / \mathrm{d}$ ) across dietary treatments, the cows that were fed the Ca salts exhibited severely depressed milk fat content $(25.6 \mathrm{~g} / \mathrm{kg}$ milk) compared to the pasture plus corn $(34.5 \mathrm{~g} / \mathrm{kg}$ milk) and TMR $(39.1 \mathrm{~g} / \mathrm{kg}$ milk) diets, resulting in lower $(P<0.01) 4 \%$ FCM yield compared to the TMR diet.

Elgersma et al. (2004) evaluated the effects on milk FA composition when transitioning from a fresh grass to a mixed grass/corn silage diet. Although DMI $(16.1 \mathrm{~kg} / \mathrm{d})$ and milk yield $(20.0 \mathrm{~kg} / \mathrm{d})$ did not differ between dietary treatments, major changes occurred in FA concentration and composition. The average milk fat concentration increased from $43.7 \mathrm{~g} / \mathrm{kg}$ milk on day 0 to $54.9 \mathrm{~g} / \mathrm{kg}$ milk on day 14 . The milk FA composition was altered within 2 days of switching to a silage-based diet. When day 0 (pasture-based diet) and day 14 (mixed silage-based diet) were compared, major changes occurred in the concentrations of $\mathrm{C}_{14: 0}, \mathrm{C}_{16: 0}, \mathrm{C}_{18: 0}$, and cis-9 $\mathrm{C}_{18: 1}$ ( 89 vs. 117,226 vs. 348,110 vs. 88 , and 238 vs. 170 $\mathrm{mg} / \mathrm{g}$ milk fat, $P<0.01$, respectively). In a similar fashion, trans-11 $\mathrm{C}_{18: 1}$ and total CLA concentrations decreased from day 0 to day 14 (46.4 vs. 7.2 and 24.3 vs. $4.4 \mathrm{mg} / \mathrm{g}$ milk fat, $P$ $<0.01$, respectively; Elgersma et al., 2004).

Common features for most, if not all, of these studies were a) the substantial variation in CLA concentration among individual cows within treatment groups consuming the same diets and subjected to the same management regimen and $b$ ) the positive linear relationship 
established between CLA and trans-11 $\mathrm{C}_{18: 1}$. The individual range in CLA concentrations for cows fed a TMR was 2.4 to $7.0 \mathrm{mg} / \mathrm{g}$ of milk FA, but this range was 6.3 to $18.1 \mathrm{mg} / \mathrm{g}$ of milk FA when the cows were fed a pasture-only diet (Kelly et al., 1998). Similar findings were reported by White et al. (2001) and Elgersma et al. (2004). The variation in CLA concentrations among individual cows has been attributed mainly to differences in rumen biohydrogenation and mammary $\Delta^{9}$-desaturase activity (Peterson et al., 2002). The positive linear relationship between CLA and trans-11 $\mathrm{C}_{18: 1}$ provides further evidence for a common origin of these two FA (Bauman and Griinari, 2001), and this association was earlier established by Jahreis et al. (1997).

\section{Lipid content and long-chain fatty acids of fresh forages}

Forages provide a low-cost alternative to improving milk fatty acid profiles relative to their impacts on human health compared to diet supplementation strategies such as oils and starch (Dewhurst et al., 2006). Dairy diets typically contain about 4\% DM soluble in ether (Jenkins, 1993). The total fatty acid concentration of temperate grasses typically ranges from 7 to $32 \mathrm{~g} / \mathrm{kg}$ DM (Dewhurst et al., 2001). Fats in the form of galactolipids represent the highest amounts of lipids ingested by grazing animals (Harfoot, 1981). Because the galactolipids are located primarily in vegetative, metabolically-active leaves, the concentration in forages is affected by the stage of maturity, the leaf-to-stem ratio, and harvesting date (Van Soest, 1994; Dewhurst et al., 2001). The FA content of pasture is highly unsaturated ( $\sim 70$ to $90 \%)$ with relatively large amounts of $\mathrm{C}_{18: 2}$ and $\mathrm{C}_{18: 3}$. Also, $\mathrm{C}_{18: 2}$ and $\mathrm{C}_{18: 3}$ are the major FA components of chloroplast membranes (Hawke, 1973). Other FA present in forages include $\mathrm{C}_{14: 0}, \mathrm{C}_{15: 0}, \mathrm{C}_{16: 0}, \mathrm{C}_{16: 1}, \mathrm{C}_{18: 1}$, and $\mathrm{C}_{20: 0}$ (Dewhurst et al., 2001). The FA composition of some common temperate pastures and pasture components was recently 
summarized by Schroeder et al. (2004). Ether extract (EE, \%DM), FA concentration (\%DM), $\mathrm{C}_{18: 2}$ and $\mathrm{C}_{18: 3}(\mathrm{~g} / 100 \mathrm{~g} \mathrm{FA})$ ranged from 3.2 to $5.3,1.7$ to $2.5,13.5$ to 18.5 , and 43.0 to 72.0 , respectively, for some of the most common cool-season grasses. Alpha-linolenic and LA were the predominant FA in freshly-harvested perennial ryegrass (69 and 12\% of total FA, respectively, Kim et al., 2005).

Pasture management including pasture species present in the mix, harvesting date, and regrowth intervals between cuts or grazing cycles, can have an effect on the amount and composition of grass FA. Previous data suggests that the proportion of leaves is critical in determining FA concentration and a significant genetic component is involved in the FA profiles of forages, suggesting future possibilities for breeding grasses for high lipid content (Dewhurst et al., 2001). After evaluating eight temperate grass species, including orchardgrass, tall fescue, and annual ryegrass, Dewhurst et al. (2001) reported a 5-fold range of total FA concentrations in samples taken from individual plots. Oddly, annual ryegrass exhibited both the highest $(31.1 \mathrm{~g} / \mathrm{kg}$ DM, harvested in November, experiment 1$)$ and the lowest $(6.1 \mathrm{~g} / \mathrm{kg}$ DM, harvested in July, experiment 2) total FA concentration. The latter experiment also evaluated the effect of regrowth interval using three ryegrass species. All three ryegrasses exhibited high concentrations of total $\mathrm{FA}$ and a high proportion of $\mathrm{C}_{18: 3}$ during active vegetative growth (late April), with total FA levels declining markedly during the summer, and recovering again during the following fall. Annual ryegrass had higher concentrations of total $\mathrm{FA}$ and $\mathrm{C}_{18: 3}$ during the early and late season compared to perennial ryegrass. Fatty acids (particularly $\mathrm{C}_{18: 2}$ and $\mathrm{C}_{18: 3}$ ) declined when the regrowth interval was extended from 20 to 38 days (5 vs. 3 harvests, respectively; Dewhurst et al., 2001). These findings were in agreement with those reported by Bauchart et al. (1984), where FA 
concentrations of perennial ryegrass were tested along seven harvesting dates from May to September. The FA concentration of ryegrass was highest for the first cut (32 $\mathrm{g} / \mathrm{kg} \mathrm{DM})$, decreased gradually during late spring/early summer (22 $\mathrm{g} / \mathrm{kg} \mathrm{DM})$ but decreased strongly during the summer for the lowest leaf/stem ratio of the season (12 $\mathrm{g} / \mathrm{kg} \mathrm{DM})$, and increased sharply with new vegetative growth occurring in early spring (31 g/kg DM, September). Although a negative balance of FA (FA entering vs. leaving the rumen) was reported for the early and late harvesting dates, a positive balance in the rumen occurred during the stem-rich canopy of the summer months. The authors speculated that the enrichment in cell-wall material during this period favored the passage of solids-associated bacteria (SAB) to the duodenum, which have higher lipid content than liquid-associated bacteria (LAB). The growth of the later group is enhanced by soluble carbohydrate concentration-rich vegetative ryegrass (Bauchart et al., 1984). Although $\mathrm{C}_{18: 2}$ and $\mathrm{C}_{18: 3}$ were the predominant $\mathrm{FA}$ in fresh forages, they were virtually absent from LAB and SAB (Kim et al., 2005).

The change in the FA profile of milk from cows fed stored forages and grain-based concentrates has been attributed to the loss of precursor FA during the processes of silage and hay making (Dewhurst et al., 2001); and the distinct nature of FA profiles reaching the rumen (Schroeder et al., 2004), respectively. Forage preservation, either by drying or silagemaking, has been reported to lower the concentration of total and polyunsaturated FA in forage dry matter (Dewhurst et al., 2003). Consequently, the modest response of CLA concentration in milk fat to feeding a high-oil corn silage (4.6 vs. $2.8 \mathrm{mg} / \mathrm{g}$ milk FA for diets with a high-oil hybrid vs. a normal hybrid, respectively) reported by Chouinard et al. (2001) may have been the result of a reduction in the total amounts of precursors for CLA due to the silage-making process. 
Losses due to oxidation of PUFA (primarily of $\mathrm{C}_{18: 3}$ ) during field wilting represent a major loss in terms of forage precursors (Dewhurst et al., 2006). These losses seem to be associated with a plant defense mechanism triggered by the onset of tissue damage which involves the lipoxygenase system (Feussner and Wasternack, 2002). Plant lipases release non-esterified $\mathrm{C}_{18: 3}$ and $\mathrm{C}_{18: 2}$ from damaged membranes and these are rapidly converted to hydroperoxy PUFA by lipoxygenases. These FA are further metabolized to volatile compounds such as leaf aldehydes and alcohols (Feussner and Wasternack, 2002). Leaf tissues contain more FA than stem tissues, which make the hay-making process a more susceptible one to FA losses compared with silage-making, due to increased leaf damage (Dewhurst et al., 2006). Aii et al. (1988) reported significant losses of $\mathrm{C}_{18: 3}$ concentrations in fresh ryegrass $(40.1 \mathrm{~g} / 100 \mathrm{~g}$ total FA) harvested as hay $(6.3 \mathrm{~g} / 100 \mathrm{~g}$ total FA) but only modest losses when harvested as haylage ( $36.4 \mathrm{~g} / 100 \mathrm{~g}$ total FA).

Compared to forages, where $\mathrm{C}_{18: 3}$ is the most abundant FA, cereal grains (i.e. corn, barley, wheat, other) and oilseeds (i.e. soybean, sunflower, canola, other) contain a high proportion of $\mathrm{C}_{18: 2}$. In addition, cereal grains are high in starch and are lower in fat (primarily phospholipids and glycolipids) concentration compared to forage. Conversely, oilseeds possess energy reserves in the form of triacylglycerides, and are high in fat (20 to $42 \mathrm{EE}$, expressed as \%DM; Schroeder et al., 2004). 


\section{LITERATURE CITED}

Aii T., S. Takahashi, M. Kurihara, and S. Kume. 1988. The effects of Italian ryegrass hay, haylage and fresh Italian ryegrass on the fatty acid composition of cows' milk. Japanese J. Zootech. Sci.59:718-724.

Allen, M. S. 1996. Physical constraints on voluntary intake of forages by ruminants. J. Anim. Sci. 74:3063-3075.

Allen, M. S. 2000. Effects of diet on short-term regulation of feed intake by lactating dairy cattle. J. Dairy Sci. 83:1598-1624.

Baile, C. A., and M. A. Della-Fera, 2002. The nature of the control of feed intake and regulation of energy balance: Recent advances. Pages 13-24 in CAES, Dept. Animal and Dairy Sci. 2001/2002 Annual Report, University of Georgia.

Baker, B. S., T. V. Eynden, and N. Boggess. 1981. Hay yield determinations of mixed swards using a disk meter. Agron. J. 73:67-69.

Bargo, F., L. D. Muller, J. E. Delahoy, and T. W. Cassidy. 2002a. Milk response to concentrate supplementation of high producing dairy cows grazing at two pasture allowances. J. Dairy Sci. 85:1777-1792.

Bargo, F., L. D. Muller, J. E. Delahoy, and T. W. Cassidy. 2002b. Performance of high producing dairy cows with three different feeding systems combining pasture and total mixed rations. J. Dairy Sci. 85:2948-2963.

Bargo, F., L. D. Muller, G. A. Varga, J. E. Delahoy, and T. W. Cassidy. 2002c. Ruminal digestion and fermentation of high-producing dairy cows with three different feeding systems combining pasture and total mixed rations. J. Dairy Sci. 85:2964-2973.

Bargo, F., L. D. Muller, E. S. Kolver, and J. E. Delahoy. 2003. Production and digestion of 
supplemented dairy cows on pasture. J. Dairy Sci. 86:1-42.

Bargo, F., D. H. Rearte, F. J. Santini, and L. D. Muller. 2001. Ruminal digestion by dairy cows grazing winter oats pasture supplemented with different levels and sources of protein. J. Dairy Sci. 84:2260-2272.

Bauchart, D., R. Verite, and B. Remond. 1984. Long-chain fatty acid digestion in lactating dairy cows fed fresh grass from spring to autumn. Can. J. Anim. Sci. 64(Suppl.):330-331.

Bauman, D. E., L. H. Baumgard, B. A. Corl, and J. M. Griinari. 1999. Biosynthesis of conjugated linoleic acid in ruminants. Proc. Am. Soc. Anim. Sci. Available at: http://www.asas.org/jas/symposia/proceedings/0937.pdf

Bauman, D. E., and J. M. Griinari. 2001. Regulation and nutritional manipulation of milk fat: low-fat milk syndrome. Livestock Prod. Sci. 70:15-29.

Baumgard, L. H., E. Matitashvili, B. A. Corl, D. A. Dwyer, and D. E. Bauman. 2002. trans10, cis-12 conjugated linoleic acid decreases lipogenic rates and expression of genes involved in milk lipid synthesis in dairy cows. J. Dairy Sci. 85:2155-2163.

Beever, D. E., A. Hattan, C. K. Reynolds, and S. B. Cammell. 1999. Nutrient supply to highyielding dairy cows. Pages 119-131 in Fertility in the High-Producing Dairy Cow (Ed. M. G. Diskin). Occ. Pub. No. 26, Brit. Soc. Anim. Sci.

Beever, D. E., and R. C. Siddons. 1986. Digestion and metabolism in grazing ruminants. Page 479-497 in Control of Digestion and Metabolism in Ruminants (Eds. L. P. Milligan, W. L. Grovum, and A. Dobson). Prentice-Hall, Banff, Canada.

Beever, D. E., and C. L. Thorp. 1997. Supplementation of forage diets. Pages 419-440 in Milk Composition, Production and Biotechnology. (Eds. R. A. S. Welch, D. J. W. Burns, S. R. Davis, A. I. Popay, and C. G. Prosser). CAB International, London, UK. 
Belury, M. A. 2002. Inhibition of carcinogenesis by conjugated linoleic acid: potential mechanisms of action. J. Nutr. 132:2995-2998.

Bertrand, J. A., S. J. Freeman, and T. C. Jenkins. 2004. Current studies in pastures and fatty acids in milk. Pages 9-13 in Proceedings of the Mid-Atlantic Grazing Conference, Roanoke, VI.

Berzaghi, P., J. H. Herbein, and C. E. Polan. 1996. Intake, site, and extent of nutrient digestion of lactating cows grazing pasture. J. Dairy Sci. 79:1581-1589.

Blaxter, K. L. 1956. The nutritive value of feeds as sources of energy: A review. J. Dairy Sci. 39:1396-1424.

Booth, R. G., S. K. Kon, W. J. Dann, and T. Moor. 1935. A study of seasonal variation in butter fat. II. A seasonal spectroscopic variation in the fatty acid fraction. Biochem. J. 29:133-137.

Brown, L. D. 1966. Influence of intake on feed utilization. J. Dairy Sci. 49:223-230.

Burns, J. C. 2005. Grazing research in the humid east: a historical perspective. Crop Sci. 46:118-130.

Burns, J. C., H. Lippke, and D. S. Fisher. 1989. The relationship of herbage mass and characteristics to animal responses in grazing experiments. Pages 7-19 in Grazing Research: Design, Methodology, and Analysis. CSSA, Madison, WI

Burns, J. C., K. R. Pond, and D. S. Fisher. 1994. Measurement of forage intake. Page 494 in Forage Quality, Evaluation, and Utilization (Eds. G. C. Fahey, M. Collins, D. R. Mertens, and L. E. Moser). ASA, CSSA, SSSA, Madison, WI.

Burns, J. C., and L. E. Sollenberger. 2002. Grazing behavior of ruminants and daily performance from warm-season grasses. Crop Sci. 42:873-881. 
Buxton, D. R., and D. R. Mertens. 1995. Quality-related characteristics of forages. Pages 8396 in Forages Volume II: The Science of Grassland Agriculture (Eds. R. F. Barnes, D. A. Miller, and C. J. Nelson) $5^{\text {th }}$ Edition. Iowa State University Press, Ames, IA.

Cabrita, A. R., A. J. M. Fonseca, R. J. Dewhurst, and E. Gomes. 2003. Nitrogen supplementation of corn silages. 2. Assessing rumen function using fatty acid profiles of bovine milk. J. Dairy Sci. 86:4020-4032.

Caird, L., and W. Holmes. 1986. The prediction of voluntary intake of grazing dairy cows. J. Agric. Sci. 107:43-54.

Carruthers, V. R., P. G. Neil, and D. E. Dalley. 1996. Microbial protein synthesis and milk production in cows offered pasture diets differing in non-structural carbohydrate content. Proc. NZ Soc. Anim. Prod. 56:255-259.

Champion, R. A., S. M. Rutter, P. D. Penning, and A. J. Rook. 1994. Temporal variation in grazing behavior of sheep and the reliability of sampling periods. Appl. Anim. Behav. Sci. 42:99-108.

Cherney, J. H., and V. G. Allen. 1995. Forages in a livestock system. Pages 175-188 in Forages Volume I: An Introduction to Grassland Agriculture (Eds. R. F. Barnes, D. A. Miller, and C. J. Nelson) $5^{\text {th }}$ Edition. Iowa State University Press, Ames, IA.

Cherney, D. J. R., and D. R. Mertens. 1998. Modeling grass utilization by dairy cattle. Pages 351-372 in Grass for Dairy Cattle (Eds. J. H. Cherney and D. J. R. Cherney). CAB International, New York, NY.

Chouinard, P.Y., L. Corneau, W. R. Butler, Y. Chilliard, J. K. Drackley, and D. E. Bauman. 2001. Effect of dietary lipid source on conjugated linoleic acid concentrations in milk fat. J. Dairy Sci. 84:680-690. 
Clark, D. A., and V. R. Kanneganti. 1998. Grazing management systems for dairy cattle. Pages 311-334 in Grass for Dairy Cattle (Eds. J. H. Cherney and D. J. R. Cherney). CAB International, New York, NY.

Clark, D. A., J. W. Penno, and P. G. Neil. 1997. Nutritional merits and problems of pasture. Pages 397-418 in Milk Composition, Production and Biotechnology. (Eds. R. A. S. Welch, D. J. W. Burns, S. R. Davis, A. I. Popay, and C. G. Prosser). CAB International, London, UK.

Coppock, C. E. 1977. Feeding methods and grouping systems. J. Dairy Sci. 60:1327-1336.

Coppock, C. E., D. L. Bath, and B. Harris, Jr. 1981. From feeding to feeding systems. J. Dairy Sci. 64:1230-1249.

Curran, M. K., and W. Holmes. 1970. Prediction of voluntary intake of food by dairy cows 2 . Lactating grazing cows. Anim. Prod. 12:213-224.

CVB, 1999a. Manual of Calculating the Feeding Value of Roughages. Centraal Veevoeder Bureau, Lelystad, The Netherlands.

CVB, 1999b. Book of Tables of Animal Nutrition. Centraal Veevoeder Bureau, Lelystad, The Netherlands.

Dalley, D. E., J. R. Roche, P. J. Moate, and C. Grainger. 2001. More frequent allocation of herbage does not improve the milk production of dairy cows in early lactation. Aust. J. Exp. Agric. 41:593-599.

Dartt, B. A., J. W. Lloyd, B. R. Radke, J. R. Black, and J. B. Kaneene. 1999. A comparison of profitability and economic efficiencies between management-intensive grazing and conventionally managed dairies in Michigan. J. Dairy Sci. 82:2412-2420.

Delahoy, J. E., L. D. Muller, F. Bargo, T. W. Cassidy, and L. A. Holden. 2003. Supplemental 
carbohydrate sources for lactating dairy cows on pasture. J. Dairy Sci. 86:906-915.

DePeters, E. J., and J. D. Ferguson. 1992. Nonprotein nitrogen and protein distribution in the milk of cows. J. Dairy Sci. 75:3192-3209.

Dewhurst, R. J., W. J. Fisher, J. K. S. Tweed, and R. J. Wilkins. 2003. Comparison of grass and legume silages for milk production. 1. Production responses with different levels of concentrate. J. Dairy Sci. 86:2598-2611.

Dewhurst, R. J., N. D. Scollan, S. J. Youell, J. K. S. Tweed, and M. O. Humphreys. 2001. Influence of species, cutting date and cutting interval on the fatty acid composition of grasses. Grass and Forage Sci. 56:68-74.

Dewhurst R. J.., K. J. Shingfield, M. R. F. Lee, and N. D. Scollan. 2006. Increasing the concentrations of beneficial polyunsaturated fatty acids in milk produced by dairy cows in high forage systems. Anim. Feed Sci. Tech. Article in Press.

Dillon, P., and S. Crosse. 1997. Current and potential production in a profitable dairy system. Pages $2-33$ in National Dairy Conference. Teagasc, Dublin, Ireland.

Dixon, R. M., and C. R. Stockdale. 1999. Associative effects between forages and grains: consequences for feed utilization. Aust. J. Agric. Res. 50:757-773.

Dhiman, T. R., G. R. Anand, L. D. Satter, and M. W. Pariza. 1999. Conjugated linoleic acid content of milk from cows fed different diets. J. Dairy Sci. 82:2146-2156.

Dougan, M. E. R., J. L. Aalhus, A. L. Schaefer, and J. K. G. Kramer. 1997. The effect of conjugated linoleic acid on fat to lean repartitioning and feed conversion in pigs. Can. J. Anim. Sci. 77:723-725.

Dove, H., and R. W. Mayes. 1991. The use of plant wax alkanes as marker substances in studies of the nutrition of herbivores: a review. Aust. J. Agric. Res. 42:913-952. 
Doyle, P. T., S. A. Francis, and C. R. Stockdale. 2005. Associative effects between feeds when concentrate supplements are fed to grazing dairy cows: a review of likely impacts on metabolizable energy supply. Aust. J. Agric. Res. 56:1315-1329.

Earle, D. F., and A. A. McGowan. 1979. Evaluation and calibration of an automated rising plate meter for estimating dry matter yield of pasture. Aust. J. Exp. Agric. Anim. Husb. 19:337-343.

Elgersma, A., G. Ellen, H. van der Horst, H. Boer, P. R. Dekker, and S. Tamminga. 2004. Quick changes in milk fat composition from cows after transition from a fresh grass to a silage diet. Anim. Feed Sci. Tech. 117:13-27.

Emmick, D. L., and L. F. Toomer. 1991. The economic impact of intensive grazing management on fifteen dairy farms in New York State. Page 19 in Forage and Grassland Conference Proceedings. American Forage and Grassland Council, Georgetown, TX.

Fales, S. L., S. A. McMurry, and W. T. McSweeny. 1993. The role of pasture in northeastern dairy farming: Historical perspective, trends and research imperatives for the future. Pages 111-133 in Agricultural Research in the Northeastern United States: Critical Review and Future Perspectives (Eds. T. Sims and O. K. Hatley). American Society of Agronomy, Madison, WI.

Fales, S. L., L. D. Muller, S. A. Ford, M. O’Sullivan, R. J Hoover, L. A. Holden, L. E. Lanyon, and D. R. Buckmaster. 1995. Stocking rate affects production and profitability in a rotationally grazed pasture system. J. Prod. Agric. 8:88-96.

Faverdin, P. 1999. The effect of nutrients on feed intake in ruminants. Proc. Nutr. Soc. $58: 523-531$.

Feussner, I., and C. Wasternack. 2002. The lipoxygenase pathway. Annu. Rev. Plant Biol. 
$53: 275-297$.

Fick, G. W., and E. A. Clark. 1998. The future of grass for dairy cattle. Pages 1-22 in Grass for Dairy Cattle (Eds. J. H. Cherney and D. J. R. Cherney). CAB International, New York, NY.

Fike, J. H., C. R. Staples, L. E. Sollenberger, B. Macoon, and J. E. Moore. 2003. Pasture forages, supplementation rate, and stocking rate effects on dairy cow performance. J. Dairy Sci. $86: 1268-1281$.

Fisher, D. S. 1994. Intake measurements with grazing animals. In: Research Techniques and Numerical Methods in Grassland and Forage Science. USDA-ARS, North Carolina State University. Available at: http://www.cropsci.ncsu.edu/dsfisher/index.html

Fontaneli, R. S., L. E. Sollenberger, R. C. Littell, and C. R. Staples. 2005. Performance of lactating dairy cows managed on pasture-based or in freestall barn-feeding systems. J. Dairy Sci. $88: 1264-1276$.

Forage and Grazing Terminology Committee. 1992. Terminology for Grazing Lands and Grazing Animals. J. Prod. Agric. 5:191-201.

Forbes, M. J. 1996. Integration of regulatory signals controlling forage intake in ruminants. J. Anim. Sci. 74:3029-3035.

Fox, D. G., C. J. Sniffen, J. D. O’Connor, J. B. Russell, and P. J. Van Soest. 1992. A net carbohydrate and protein system for evaluating cattle diets. III. Cattle requirements and diet adequacy. J. Anim. Sci. 70:3578-3596.

Garcia, S. C., C. W. Holmes, J. Hodgson, and A. MacDonald. 2000. The combination of the n-alkanes and ${ }^{13} \mathrm{C}$ techniques to estimate individual dry matter intakes of herbage and maize silage by grazing dairy cows. J. Agric. Sci. 135:47-55. 
Gibb, M. J., C. A. Huckle, R. Nuthall, and A. J. Rook. 1997. Effect of sward surface height on intake and grazing behavior by lactating Holstein-Friesian cows. Grass Forage Sci. $52: 309-321$.

Griinari, J. M., B. A. Corl, S. H. Lacy, P. Y. Chouinard, K. V. Nurmela, and D. E. Bauman. 2000. Conjugated linoleic acid is synthesized endogenously in lactating dairy cows by Delta(9)-desaturase. J. Nutr. 130:2285-2291.

Grummer, R. R. 1991. Effect of feed on the composition of milk fat. J. Dairy Sci. 74:32443257.

Ha, Y. L., N. K. Grimm, and M. W. Pariza. 1987. Anticarcinogens from fried ground beef: heat-altered derivatives of linoleic acid. Carcinogenesis 8:1881-1888.

Ha, Y. L., J. M. Storkson, and M. W. Pariza. 1990. Inhibition of benzo(a)pyrene-induced mouse forestomach neoplasia by conjugated dienoic derivatives of linoleic acid. Cancer Res. 50:1097-1101.

Hanson, G. D., L. C. Cunningham, M. J. Morehart, and R. L. Parsons. 1998. Profitability of moderate intensive grazing of dairy cows in the northeast. J. Dairy Sci. 81:821-829.

Harfoot, C. G. 1981. Lipid metabolism in the rumen. Pages 21-56 in Lipid Metabolism in Ruminant Animals (Ed. W. W. Christie). Pergamon Press, New York, NY.

Harmoney, K. R., K. J. Moore, J. R. George, E. C. Brummer, and J. R. Russell. 1997. Determination of pasture biomass using four indirect methods. Agron. J. 89:665-672.

Harvatine, K. J., and M. S. Allen. 2004. Kinetic model of rumen biohydrogenation: fractional rates of fatty acid biohydrogenation and passage. J. Anim. Feed Sci. 13, Suppl.1:87-90. Hawke, J. C. 1973. Lipids. Pages 213-263 in Chemistry and Biochemistry of Herbage (Eds. U. W. Butler and R. W. Bailey). Academic Press, London, UK. 
Herbein, J. H., J. J. Loor, and W. A. Wark. 2004. Conjugated linoleic acids: An opportunity for pasture-based farms? Pages 3-8 in Proceedings of the Mid-Atlantic Grazing Conference, Roanoke, VI.

Hespell, R. B., and P. J. O'Bryan-Shah. 1988. Esterase activities in Butyrivibrio fibrisolvens strains. Appl. Environ. Microbiol. 54:1917-1922.

Hodgson, J. 2004. Measurements of herbage intake and ingestive behavior in grazing animals: an introduction. Pages $15-21$ in Herbage Intake Handbook, $2^{\text {nd }}$ Edition (Ed. P. D. Penning). Br. Grassl. Soc. Reading, UK.

Hodgson, J. 1985. The control of herbage intake in the grazing ruminant. Proc. Nutr. Soc. 44:339-346.

Hodgson, J., and I. M. Brookes. 1999. Nutrition of grazing animals. Page 117 in Pasture and Crop Science (Eds. J. White and J. Hodgson). Oxford University Press, Auckland, NZ.

Hoffman, K., L. D. Muller, S. L. Fales, and L. A. Holden. 1993. Quality evaluation and concentrate supplementation of rotational pasture grazed by lactating dairy cows. J. Dairy Sci. 76:2651-2663.

Holden, L. A., L. D. Muller, and S. L. Fales. 1994a. Estimation of intake in high producing Holstein cows grazing grass pasture. J. Dairy Sci. 77:2332-2340.

Holden, L. A., L. D. Muller, T. Lykos, and T. W. Cassidy. 1995. Effect of corn silage supplementation on intake and milk production in cows grazing grass pasture. J. Dairy Sci. 78:154-160.

Holden, L. A., L. D. Muller, G. A. Varga, and P. J. Hillard. 1994b. Ruminal digestion and duodenal nutrient flows in dairy cows consuming grass as pasture, hay, or silage. J. Dairy Sci. 77:3034-3042. 
Holmes, C. W., G. F. Wilson, D. D. S. Mackenzie, D. S. Flux, I. M. Brooks, and A. W. F. Davey. 1984. Nutrition: Food intake and nutritive value. Page 131 in Milk Production from Pasture (Eds. C. W. Holmes and G. F. Wilson). Butterworths of New Zealand, Wellington, NZ.

Hongerholt, D. D., and L. D. Muller. 1998. Supplementation of rumen-undegradable protein to the diets of early lactation Holstein cows on grass pasture. J. Dairy Sci. 81:2204-2214.

Horn, F. P. 1981. Direct measurement of voluntary intake of grazing livestock by telemetry. Pages 367-372 in Forage Evaluation: Concepts and Techniques (Eds. J. W. Wheeler and R. D. Mochrie). Griffin Press Limited, Netley, South Australia.

Houseknecht, K. L., J. P. Vanden Heuvel, S. Y. Moya-Camarena, C. P. Portocarrero, L. W. Peck, K. P. Nickel, and M. A. Belury. 1998. Dietary conjugated linoleic acid normalizes impaired glucose tolerance in the Zucker diabetic fatty fa/fa rat. Biochem. Biophys. Res. Commun. 244:678-682.

Huffman, C. F. 1961. High-level grain feeding for dairy cows. J. Dairy Sci. 44:2113-2122.

Ip, C., M. Singh, H. J. Thompson, and J. A. Scimeca. 1999. Conjugated linoleic acid suppresses mammary carcinogenesis and proliferative activity of the mammary gland in the rat. Cancer Res. 54:1212-1215.

Jahreis, G., J. Fritsche, and H. Steinhart. 1997. Conjugated linoleic acid in milk fat: high variation depending on production system. Nutr. Res. 17:1479-1484.

Jenkins, T. C. 1993. Lipid metabolism in the rumen. J. Dairy Sci. 76:3851-3863.

Jenkins, T. C., and M. A. McGuire. 2006. Major advances in nutrition: Impact on milk composition. J. Dairy Sci. 89:1302-1310.

Jensen, R. G. 2000. Fatty acids in milk and dairy products. Pages 109-123 in Fatty Acids in 
Foods and their Health Implications (Ed. C. N. Chow). Marcel Dekker, Inc. New York, NY. Jones-Endsley, J. M., M. J. Cecava, and T. R. Johnson. 1997. Effects of dietary supplementation on nutrient digestion and the milk yield of intensively grazed lactating dairy cows. J. Dairy Sci. 80:3283-3292.

Kelly, M. L., E. S. Kolver, D. E. Bauman, M. E. Van Amburgh, and L. D. Muller. 1998. Effect of intake of pasture on concentrations of conjugated linoleic acid in milk of lactating dairy cows. J. Dairy Sci. 81:1630-1636.

Kepler, C. R., K. P. Hirons, J. J. McNiell, and S. B. Tove. 1966. Intermediates and products of the biohydrogenation of linoleic acid by Butyrivibrio fibrisolvens. J. Biol. Chem. 241:1350-1354.

Kepler, C. R., and S. B. Tove. 1967. Biohydrogenation of unsaturated fatty acids. J. Biol. Chem. 242:5686-5692.

Kepler, C. R., W. P. Tucker, and S. B. Tove. 1971. Biohydrogenation of unsaturated fatty acids. V. Stereospecificity of proton addition and mechanism of action of linoleic acid $\Delta^{12}-$ cis, $\Delta^{11}$-trans-isomerase from Butyrivibrio fibrisolvens. J. Biol. Chem. 246:2765-2771.

Kim, Y. J., R. H. Liu, D. R. Bond, and J. B. Russell. 2000. Effect of linoleic acid concentration on conjugated linoleic production by Butyrivibrio fibrisolvens A38. App. Environ. Microbiol. 66:5226-5230.

Kim, E. J., R. Sanderson, M. S. Dhanoa, and R. J. Dewhurst. 2005. Fatty acid profiles associated with microbial colonization of freshly ingested grass and rumen biohydrogenation.

J. Dairy Sci. 88:3220-3230.

Klopfenstein, T.J., R. A. Mass, K. W. Creighton, and H. H. Patterson. 2001. Estimating forage protein degradation in the rumen. J. Anim. Sci. 79(Suppl.):E208-E216. 
Klusmeyer, T. H., and J. H. Clark. 1991. Effects of dietary fat and protein on fatty acid flow to the duodenum and in milk produced by dairy cows. J. Dairy Sci. 74:3055-3067.

Kolver, E. S., and L. D. Muller. 1998. Performance and nutrient intake of high producing Holstein cows consuming pasture or a total mixed ration. J. Dairy Sci. 81:1403-1411.

Kolver, E. S., L. D. Muller, M. C. Barry, and J. W. Penno. 1998. Evaluation and application of the net carbohydrate and protein system for dairy cows fed diets based on pasture. J. Dairy Sci. 81:2029-2039.

Laca, E. A., E. D. Ungar, N. Seligman, and M. W. Demment. 1992. Effects of sward height and bulk density on bite dimensions of cattle grazing homogenous swards. Grass Forage Sci. 47:91-102.

Lantinga, E. A., J. H. Neuteboom, and J. A. C. Meijs. 2004. Sward methods. Pages 23-52 in Herbage Intake Handbook, $2^{\text {nd }}$ Edition (Ed. P. D. Penning). Br. Grassl. Soc. Reading, UK. Lassiter, C. A., D. M. Seath, J. W. Woodruff, J. A. Taylor, and J. W. Rust. 1956. Comparative value of Kentucky bluegrass, Kentucky 31 fescue, orchardgrass, and bromegrass as pastures for milk cows. II. Effect of kind of grass on the dry matter and crude protein content and digestibility and intake of dry matter. J. Dairy Sci. 39:581-587.

Lean, I. J., W. J. Parker, and R. C. Kellaway. 1996. Improving the efficiency of pasturebased dairy production. Proc. N. Z. Soc. Anim. Prod. 56:270-275.

Leaver, J. D. 1982. Herbage Intake Handbook, $1^{\text {st }}$ Edition. Br. Grassl. Soc. Hurley, UK.

Leaver, J. D. 1985. Milk production from grazed temperate grassland. J. Dairy Res. 52:313344.

Leaver, J. D. 1986. Effects of supplements on herbage intake and performance. Pages 79-88 in Grazing. Occasional Publication No. 19 (Ed. J. Frame). Br. Grassl. Soc. Hurley, UK. 
Leaver, J. D. 1988. The contribution of grass and conserved forages to the nutrient requirements for milk production. Pages 213-222 in Recent Developments in Ruminant Nutrition-2 (Eds. W. Haresign and D. J. A. Cole). Butterworths, London, UK.

Le Du, Y. L. P., and P. D. Penning. 1982. Animal based techniques for estimating herbage intake. Page 37 in Herbage Intake Handbook, $1^{\text {st }}$ Edition (Ed. J. D. Leaver). Br. Grassl. Soc. Hurley, UK.

Lee, K. N., D. Kritchevsky, and M. W. Pariza. 1994. Conjugated linoleic acid and atherosclerosis in rabbits. Atherosclerosis 108:19-25.

Liew, C., H. A. Schut, S. F. Chin, M. W. Pariza, and R. H. Dashwood. 1995. Protection of conjugated linoleic acid against 2-amono-3-methylimidazo[4,5-f]quinoline-induced colon carcinogenesis in the F344 rat: a study of inhibitory mechanisms. Carcinogenesis 16:30373043.

Lippke, H. 2002. Estimation of forage intake by ruminants on pasture. Crop Sci. 42:869-872. Lock, A. L., and D. E. Bauman. 2004. Modifying milk fat composition of dairy cows to enhance fatty acids beneficial to human health. Lipids 39:1197-1206.

Lock, A. L., and K. J. Shingfield. 2004. Optimizing milk composition. Pages 107-188 in Dairying: Using Science to Meet Consumers' Needs (Eds. E. Kebreab, E. Mills, D. E. Beever). Pub. No. 29, Brit. Soc. Anim. Sci. Nottingham University Press, Loughborough, UK.

Loor, J. J., F. D. Soriano, X. Lin, J. H. Herbein, and C. E. Polan. 2003. Grazing allowance after the morning or afternoon milking for lactating dairy cows fed a total mixed ration (TMR) enhances trans11-18:1 and cis9, trans11-18:2 (rumenic acid) in milk fat to different extents. Anim. Feed Sci. Tech. 109:105-119. 
Macoon, B., L. E. Sollenberger, J. E. Moore, C. R. Staples, J. H. Fike, and K. M. Portier. 2003. Comparison of three techniques for stimulating the forage intake of lactating dairy cows on pasture. J. Anim. Sci. 81:2357-2366.

MAFF. 1975. Energy allowances and feeding systems for ruminants. Technical Bulletin 33. Ministry of Agriculture, Fisheries and Food, London, UK.

Malossini, F., S. Bovolenta, E. Piasentier, and M. Valentinotti. 1994. Variability of $n$-alkanes content in a natural pasture and in feces of grazing dairy cows. Anim. Feed Sci. Technol. $50: 113-122$.

Malossini, F., S. Bovolenta, E. Piasentier, C. Piras, and F. Martillotti. 1996. Comparison of $n$-alkanes and chromium oxide methods for estimating herbage intake by grazing dairy cows. Anim. Feed Sci. Technol. 61:155-165.

Mannetje, L. 't. 2000. Measuring biomass of grassland vegetation. Pages 151-177 in Field and Laboratory Methods for Grassland and Animal Production Research (Eds. L. t'Mannetje and R. M. Jones). CAB International, Wallingford, Oxon, UK.

Mayes R. W., C. S. Lamb, and P.M. Colgrove. 1986. The use of dosed and herbage $n$-alkanes as markers for the determination of herbage intake. J. Agric. Sci.107:161-170.

Mayne, C. S., and I. A. Wright. 1988. Herbage intake and utilization by the grazing dairy cow. Pages 280-293 in Nutrition and Lactation in the Dairy Cow (Ed. P. C. Garnsworthy). Butterworth, London, UK.

McCormick, M. E., J. D. Ward, D. D. Redfearn, D. D. French, D. C. Blouin, A. M. Chapa, and J. M. Fernandez. 2001. Supplemental dietary protein for grazing dairy cows: effect on pasture intake and lactation performance. J. Dairy Sci. 84:896-907.

McCoy, G. C., H. S. Thurmon, H. H. Olson, and A. Reed. 1966. Complete feed rations for 
lactating dairy cows. J. Dairy Sci. 49:1058-1063.

McGilloway, D. A., and C. S. Mayne. 1996. The importance of grass availability for the high genetic merit dairy cow. Page 135 in Recent Advances in Animal Nutrition (Eds. P. C. Garnsworthy, J. Wiseman, and W. Haresign). Nottingham University Press, UK.

McGuire, M. A., and M. K. McGuire. 1999. Conjugated linoleic acid (CLA): a ruminant fatty acid with beneficial effects on human health. Proc. Am. Soc. Anim. Sci. Available at: http://www.asas.org/jas/symposia/proceedings/0938.pdf

McNamara, J. P., J. France, and D. E. Beever. 2000. Modeling nutrient utilization in farm animals. CAB International, Reading, UK

Meijs, J. A. C., R. J. K. Walters, and A. Keen. 1982. Sward methods. Page 11 in Herbage Intake Handbook (Ed. J. D. Leaver). Br. Grassl. Soc., Hurley, UK.

Meijs, J. A. C. 1983. Effect of herbage mass and allowance upon herbage intake by grazing dairy cows. Pages 667-670 in Proc. $14^{\text {th }}$ Int. Grassl. Congr. Lexington, KY.

Mertens, D. R. 2002. Physical and chemical characteristics of fiber affecting dairy cow performance. Pages 125-144 in Proc. Cornell Nutrition Conf. Cornell Univ., Ithaca, NY.

Minson, D. J. 1990. Intake of grazed forage. Pages 60-84 in Forage in Ruminant Nutrition (Ed. T. J. Cunha). Academic Press, San Diego, CA.

Moore, K. C. 1998. Economics of grass for dairy cattle. Pages 373-391 in Grass for Dairy Cattle (Eds. J. H. Cherney and D. J. R. Cherney). CAB International, New York, NY.

Muller, L. D., and S. L. Fales. 1998. Cool-season grass pastures for dairy cattle. Pages 335350 in Grass for Dairy Cattle (Eds. J. H. Cherney and D. J. R. Cherney). CAB International, New York, NY.

National Agricultural Statistics Service (NASS). 2006. Milk Production. Agricultural 
Statistics Board, U.S. Department of Agriculture.

National Research Council. 1989. Nutrient Requirements of Dairy Cattle. $6^{\text {th }}$ Revised Edition. National Academies Press, Washington, DC.

National Research Council. 2001. Nutrient Requirements of Dairy Cattle. $7^{\text {th }}$ Revised Edition. National Academies Press, Washington, DC.

Orskov, E. R., and I. McDonald. 1979. The estimation of protein degradability in the rumen from incubation measurements weighed according to rate of passage. J. Agric. Sci. (Camb.) 92:499-503.

Palmquist, D. L. 2001. Ruminal and endogenous synthesis of CLA in cows. Australian J. Dairy Tech. 56:134-137.

Palmquist, D. L., and T. C. Jenkins. 1980. Fat in lactation rations: review. J. Dairy Sci. 63:114.

Pariza, M. W., S. H. Ashoor, F. S. Chu, and D. B. Lund. 1979. Effects of temperature and time on mutagen formation in pan-fried hamburger. Cancer Lett. 7:63-69.

Pariza, M. W., L. J. Loretz, J. M. Storkson, and N. C. Holland. 1983. Mutagens and modulator of mutagenesis in fried ground beef. Cancer Res. (Suppl.) 43:2444s-2446s.

Park, Y., K. J. Albright, J. M. Storkson, W. Liu, and M. W. Pariza. 1999. Evidence that the trans-10, cis-12 isomer of conjugated linoleic acid induces body composition changes in mice. Lipids. 34:235-241.

Parker, W. J., L. D. Muller, and D. R. Buckmaster. 1992. Management and economic implications of intensive grazing on dairy farms in the northeastern states. J. Dairy Sci. 75:2587-2597.

Parodi, P. W. 1977. Conjugated octadecadienoic acids of milk fat. J. Dairy Sci. 60:1550- 
1553.

Parodi, P. W. 1994. Conjugated linoleic acid: an anticarcinogenic fatty acid present in milk fat. Aust. J. Dairy Technol. 49:93-97.

Penning, P. D., A. J. Parsons, R. J. Orr, and T. T. Treacher. 1991. Intake and behavior responses by sheep to changes in sward characteristics under continuous grazing. Grass Forage Sci. 46:15-28.

Penning, P. D., and S. M. Rutter. 2004. Ingestive behavior. Pages 151-175 in Herbage Intake Handbook, $2^{\text {nd }}$ Edition (Ed. P. D. Penning). Br. Grassl. Soc. Reading, UK.

Penno, J. W., K. A. Macdonald, and A. M. Bryant. 1996. The economics of No. 2 Dairy Systems. Proceedings of the Ruakura Dairy Farmer's Conference 48:11-19.

Peterson, D. G., J. A. Kelsey, and D. E. Bauman. 2002. Analysis of variation in cis-9, trans11 conjugated linoleic acid (CLA) in milk fat of dairy cows. J. Dairy Sci. 85:2164-2172.

Peyraud, J. L. 1998. Techniques for measuring fecal flow, digestibility and intake of herbage in grazing ruminants. Page 39 in Techniques for Investigating Intake and Ingestive Behavior by Farm Animals. IX ${ }^{\text {th }}$ European Intake Workshop. IGER, North Wyke, UK.

Polan, C. E., R. E. Blaser, C. N. Miller, and D. D. Wolf. 1986. Utilization of pasture by lactating cows. J. Dairy Sci. 69:1604-1612.

Poppi, D. P., T. P. Hughes, and P. J. L'Huillier. 1987. Intake of pasture by grazing ruminants. Pages 55-64 in Livestock Feeding on Pasture (Ed. A. M. Nicol). NZ Soc. Anim. Prod. Occasional Publication No 10. Hamilton, NZ.

Pratt, A. D., and R. R. Davis. 1956. High vs. low protein grain mixture as supplements to legume-grass pastures. J. Dairy Sci. 39:1304-1308.

Pulido, R., and j. D. Leaver. 1995. Influence of initial milk yield, sward height and 
concentrate level on herbage intake and grazing behavior of dairy cattle. Ann. Zootech. 44:129.

Rakes, A. H. 1969. Complete rations for dairy cattle. J. Dairy Sci. 52:870-875.

Reeves, M., W. J. Fulkerson, R. C. Kellaway, and H. Dove. 1996. A comparison of three techniques to determine the herbage intake of dairy cows grazing kikuyu (Pennisetum clandestinum) pasture. Aust. J. Exp. Agric. 36:23-30.

Reid, J. T. 1956. Nutrition and feeding of dairy cattle. J. Dairy Sci. 39:735-763.

Reid J. T., P. W. Moe, and H. F. Tyrrell. 1966. Energy and protein requirements of milk production. J. Dairy Sci. 49:215-223.

Reis, R. B., and D. K. Combs. 2000. Effects of increasing levels of grain supplementation on rumen environment and lactation performance of dairy cows grazing grass-legume pasture. J. Dairy Sci. 83:2888-2898.

Reis, R. B., F. San Emeterio, D. K. Combs, L. D. Satter, and H. N. Costa. 2001. Effects of corn particle size and source on performance of lactating cows fed direct-cut grass-legume forage. J. Dairy Sci. 84:429-441.

Riel, R. R. 1963. Physico-chemical characteristics of Canadian milk fat. Unsaturated fatty acids. J. Dairy Sci. 46:102-106.

Rook, A. J., and C. A. Huckle. 1997. Activity bout criteria for grazing dairy cows. Appl. Anim. Behav. Sci. 54:89-96.

Ruiz, R., P. J. Van Soest, M. E. Van Amburgh, D. G. Fox, and J. B. Robertson. 2001. Use of chromium mordanted neutral detergent residue as a predictor of fecal output to estimate intake in grazing high producing Holstein cows. Anim. Feed Sci. Technol. 89:155-164.

Salinas, H. G., W. C. Stringer, E. M. Kesler, and G. L. Hargrove. 1983. Performance of dairy 
cows in midlactation fed high quality grass pasture and concentrate at three percents of energy requirements. J. Dairy Sci. 66:514-519.

Sanderson, M. A., C. A. Rotz, S. W. Fultz, and E. B. Rayburn. 2001. Estimating forage mass with a commercial capacitance meter, rising plate meter, and pasture ruler. Agron. J. 93:1281-1286.

Satter, L. D., H. G. Jung, A. M. van Vuuren, and F. M. Engels. 1999. Challenges in the nutrition of high-producing ruminants. Pages 609-646 in Nutritional Ecology of Herbivores. Proc. $5^{\text {th }}$ Int. Symp. Nutr. Herbivores (Eds. H. G. Jung and G. C. Fahey, Jr.). Am. Soc. Anim. Sci., Savoy, IL.

Schroeder, G. F., J. J. Couderc, F. Bargo, and D. H. Rearte. 2005. Milk production and fatty acid profile of milk fat by dairy cows fed a winter oats (Avena sativa L.) pasture only or a total mixed ration. New Zealand J. Agric. Res. 48:187-195.

Schroeder, G. F., J. E. Delahoy, I. Vidaurreta, F. Bargo, G. A. Gagliostro, and L. D. Muller. 2003. Milk fatty acid composition of cows fed a total mixed ration or pasture plus concentrates replacing corn with fat. J. Dairy Sci. 86:3237-3248.

Schroeder, G. F., G. A. Gagliostro, F. Bargo, J. E. Delahoy, and L. D. Muller. 2004. Effects of fat supplementation on milk production and composition by dairy cows on pasture: a review. Livestock Prod. Sci. 86:1-18.

Seath, D. M., C. A. Lassiter, J. W. Rust, M. Cole, and G. M. Bastin. 1956. Comparative value of Kentucky bluegrass, Kentucky 31 fescue, orchardgrass, and bromegrass as pastures for milk cows. I. How kind of grass affected persistence of milk production, TDN yield, and body weight. J. Dairy Sci. 39:574-580.

Short, S. D. 2004. Characteristics and Production Costs of U.S. Dairy Operations. USDA 
Statistical Bulletin No. 974-6. 20 pp. ARMS of Milk Producers, USDA, ERS.

Sinclair, L. A., S. L. Cooper, J. A. Huntington, R. G. Wilkinson, K. G. Hallett, M. Enser, and J. D. Wood. 2005. In vitro biohydrogenation of $n-3$ polyunsaturated fatty acids protected against ruminal microbial metabolism. Animal Feed Sci. Tech. 123-124:579-596.

Smit, H. J., H. Z. Taweel, B. M. Tas, S. Tamminga, and A. Elgersma. 2005. Comparison of techniques for estimating herbage intake of grazing dairy cows. J. Dairy Sci. 88:1827-1836.

Sniffen, C. J., J. D. O’Connor, P. J. Van Soest, D. G. Fox, and J. B. Russell. 1992. A net carbohydrate and protein system for evaluating cattle diets. II. Carbohydrate and protein availability. J. Anim. Sci. 70:3562-3577.

Soder, K. J., and C. A. Rotz. 2001. Economic and environmental impact of four levels of concentrate supplementation in grazing dairy herds. J. Dairy Sci. 84:2560-2572.

Sollenberger, L. E., and D. J. R. Cherney. 1995. Evaluating forage production and quality. Pages 97-110 in Forages Volume II: The Science of Grassland Agriculture (Eds. R. F. Barnes, D. A. Miller, and C. J. Nelson) $5^{\text {th }}$ Edition. Iowa State University Press, Ames, IA. Soriano, F. D., C. E. Polan, and C. N. Miller. 2000. Milk production and composition, rumen fermentation parameters, and grazing behavior of dairy cows supplemented with different forms and amounts of corn grain. J. Dairy Sci. 83:1520-1529.

Soriano, F. D., C. E. Polan, and C. N. Miller. 2001. Supplementing pasture to lactating Holsteins fed a total mixed ration. J. Dairy Sci. 84:2460-2468.

Stockdale, C. R., R. Currie, and T. E. Trigg. 1990. Effects of pasture and supplement quality on the responses of lactating dairy cows to high energy supplements. Aust. J. Exp. Agric. $30: 43-50$.

Stockdale, C. R., G. P. Walker, W. J. Wales, D. E. Dalley, A. Birkett, Z. Shen, and P. T. 
Doyle. 2003. Influence of pasture and concentrates in the diet of grazing dairy cows on the fatty acid composition of milk. J. Dairy Res. 70:267-276.

Tauer, L. W. 2001. Efficiency and competitiveness of the small New York dairy farm. J. Dairy Sci. 84:2573-2576.

Taweel, H. Z., B. M. Tas, J. Dijkstra, and S. Tamminga. 2004. Intake regulation and grazing behavior of dairy cows under continuous stocking. J. Dairy Sci. 87:3417-3427.

Tilley, J. M., and R. A. Terry. 1963. A two-stage technique for in vitro digestion of forage crops. J. Br. Grassl. Soc. 18:104-111.

Tucker, W. B., B. J. Rude, and S. Wittayakun. 2001. Case study: performance and economics of dairy cows fed a corn silage-based total mixed ration or grazing annual ryegrass during mid to late lactation. Prof. Anim. Scientist 17:195-201.

Ulyatt, M. J., and G. C. Waghorn. 1993. Limitations to high levels of dairy production from New Zealand pastures. Pages 11-32 in Improving the Quality and Intake of Pasture-Based Diets for Lactating Dairy Cows (Eds. N. J. Edwards and W. J. Parker). Massey University, Palmerston North, NZ.

Valiente, O. L., D. Andueza, A. de Vega, G. Olmos, and F. Muñoz. 2004. The use of NIRS for prediction of intake, digestibility and diet composition in sheep fed mixed grain:roughage diets. J. Anim. Feed Sci. 13:227-230.

Van Soest, P. J. 1994. Nutritional Ecology of the Ruminant, $2^{\text {nd }}$ Edition. Cornell University Press, Ithaca, NY.

Vasquez, O. P., and T. R. Smith. 2000. Factors affecting pasture intake and total dry matter intake in grazing dairy cows. J. Dairy Sci. 83:2301-2309.

Vasquez, O. P., and T. R. Smith. 2001. Evaluation of alternative algorithms used to simulate 
pasture intake in grazing dairy cows. J. Dairy Sci. 84:860-872.

Vaughan, J. M., J. A. Bertrand, T. C. Jenkins, and B. W. Pinkerton. 2002. Effects of feeding time on nitrogen capture by lactating dairy cows grazing rye pasture. J. Dairy Sci. 85:12671272.

Walker, G. P., F. R. Dunshea, and P. T. Doyle. 2004. Effects of nutrition and management on the production and composition of milk fat and protein: a review. Australian J. Agric. Res. 55:1009-1028.

Webby, R. W., and W. J. Pengelly. 1986. The use of pasture height as a predictor of feed level in North Island hill country. Proc. N. Z. Grassl. Assoc. 47:249-253.

Wilkerson, V. A., B. P. Glenn, and K. R. McLeod. 1997. Energy and nitrogen balance in lactating cows fed diets containing dry or high moisture corn in either rolled or ground form. J. Dairy Sci. 80:2487-2496.

White, S. L., G. A. Benson, S. P. Washburn, and J. T. Green, Jr. 2002. Milk production and economic measures in confinement or pasture systems using seasonally calved Holstein and Jersey cows. J. Dairy Sci. 85:95-104.

White, S. L., J. A. Bertrand, M. R. Wade, S. P. Washburn, J. T. Green, Jr., and T. C. Jenkins. 2001. Comparison of fatty acid content of milk from Jersey and Holstein cows consuming pasture or a total mixed ration. J. Dairy Sci. 84:2295-2301.

Wijesundera, C., Z. Shen, W. J. Wales, and D. E. Dalley. 2003. Effect of cereal and fiber supplements on the fatty acid composition of milk fat of grazing dairy cows in early lactation. J. Dairy Res. 70:257-265.

Woodward, T. E. 1936. The quantities of grass that dairy cows will graze. J. Dairy Sci. 19:347-357. 
World Health Organization. 2003. Diet, nutrition and the prevention of chronic diseases. Report of a joint WHO/FAO Expert Consultation. WHO Technical Report Series 916, Geneva, Switzerland.

Wu, Z., Massingill, L. J., R. P. Walgenbach, and L. D. Satter. 2001. Cracked dry or finely ground high moisture shelled corn as a supplement for grazing cows. J. Dairy Sci. 84:22272230.

Wu, Z., O. A. Ohajuruka, and D. L. Palmquist. 1991. Ruminal synthesis, biohydrogenation, and digestibility of fatty acids by dairy cows. J. Dairy Sci. 74:3025-3034. 


\section{CHAPTER 3}

PERFORMANCE OF LACTATING DAIRY COWS FED VARYING LEVELS OF TOTAL MIXED RATION AND PASTURE 


\begin{abstract}
Two, 8-week experiments, each with 30 lactating Holstein cows, were conducted to examine animal performance under different combinations of partially-restricted total mixed ration (TMR) feeding and grazing of high-quality pasture. Experiment 1 was initiated in mid October 2004 (F2004) and cows averaged $32.4 \pm 2.5 \mathrm{~kg}$ milk, $87.1 \pm 9.2$ days in milk (DIM), $1.6 \pm 0.2$ lactations, $560.6 \pm 11.8 \mathrm{~kg}$ body weight $(\mathbf{B W})$, and $3.03 \pm 0.06$ body condition score (BCS). Experiment 2 was initiated in late March 2005 (S2005) and cows averaged 36.6 $\pm 1.5 \mathrm{~kg}$ milk, $125.7 \pm 6.7 \mathrm{DIM}, 1.9 \pm 0.2$ lactations, $607.3 \pm 11.9 \mathrm{~kg} \mathrm{BW}$, and $2.88 \pm 0.06$ BCS. Cows were assigned to either an all-TMR diet (100T, no access to pasture, positive control) or one of the following three initially formulated partial mixed ration (PMR) systems: 1) 85\% TMR-restricted (85T), 2) 70\% TMR-restricted (70T), and 3) 55\% TMRrestricted (55T) dietary treatments. The actual PMR consumed were 79\% TMR and 21\% pasture, 68\% TMR and 32\% pasture, and 59\% TMR and 41\% pasture, respectively, in F2004 and $89 \%$ TMR and 11\% pasture, 79\% TMR and 21\% pasture, and $65 \%$ TMR and 35\% pasture, respectively, in F2005. Cows on the TMR-restricted diets had access to pasture (annual ryegrass, average paddock size 0.18 and 0.15 ha/d for F2004 and S2005, respectively) and grazed as a single group for $7 \mathrm{~h} / \mathrm{d}$ between a.m. and p.m. milkings. Pasture dry matter intake (DMI) estimates were based on herbage mass disappearance and calculated from the difference between pre- and post-grazing herbage mass. Data for variables measured were analyzed according to a randomized complete block design. An adaptation period occurred during the first 3 weeks and a sampling period followed during the last 5 weeks. In F2004, total daily DM, NDF, and $\mathrm{NE}_{1}$ intakes, but not CP intakes, were greatest ( $P$ $<0.05$ ) for $100 \mathrm{~T}$ compared to all three grazing groups. In S2005, total daily DMI, CP, NDF,
\end{abstract}


and $\mathrm{NE}_{1}$ intakes were greatest $(P<0.05)$ for $100 \mathrm{~T}$ compared to all three grazing groups. Although the TMR feeding system maximized total DMI and milk production in the fall trial, 4\% FCM, milk fat and protein yields did not differ among dietary treatments. In the spring trial, 4\% FCM was greatest for treatments $85 \mathrm{~T}$ and $100 \mathrm{~T}$, and lowest for treatment $70 \mathrm{~T}$, with 55T yielding intermediate. Milk fat and protein yields were greatest for treatments $85 \mathrm{~T}$ and $100 \mathrm{~T}$ compared with those dietary treatments that had greater DMI from pasture. Greatest DMI from pasture was associated with the greatest concentration of CLA in milk. Concentrations of saturated fatty acids in milk fat were greatest for cows consuming TMR, and decreased with increasing amounts of pasture DMI. Intakes of TMR were kept high in accordance with what was offered, but restricting TMR intake lowered total DMI. Gross feed efficiencies (daily 4\% FCM yield per kg DMI) were similar for all dietary treatments during the fall, but cows consuming partial mixed rations exhibited enhanced gross feed efficiencies during the spring, compared to cows consuming TMR exclusively. These studies suggest that TMR can be replaced with high-quality pasture up to the greatest amount of pasture DMI tested and that in PMR feeding systems such as the ones tested in this study, pasture can be as high as $41 \%$ without affecting milk yield when compared to an all-TMR ration.

(Key words: total mixed ration, grazing, milk yield, milk composition) 


\section{INTRODUCTION}

The need to adapt to economic pressures in order to remain profitable is a characteristic of modern dairying in the Eastern U.S. A scenario led by low milk prices and narrow profit margins during the last two decades has caused an increasing number of dairy farmers to look for alternative and more profitable feeding systems (Muller and Fales, 1998). Concurrently, a remarkable body of dairy grazing literature has surfaced in the last two decades in eastern U.S. In addition to the search for low-cost feeding systems, environmentally-friendly practices have resulted in an increasing interest in pasture-based dairy farming in southeastern U.S. Previous long-term studies conducted in the Mid-Atlantic region have showed that pasture-based dairying can be competitive in terms of profitability (White et al., 2002) and are environmentally sustainable (White et al., 2001b) compared with confinement systems.

Supplemental energy needs to be fed to high producing dairy cows on pasture in order to meet genetic potential for lactation performance. Substantial evidence from research studies conducted in the Eastern U.S. comparing dairy confinement systems with pasturebased systems (with or without supplementation) consistently shows reduced dry matter intake, milk production, and body condition scores for pasture-based dairying (Kolver and Muller, 1998; Soriano et al., 2001; White et al., 2002; Bargo et al., 2002a; Fontaneli et al., 2005). In addition, the lack of confidence in the ability of pastures to provide high quality forage during prolonged periods of time, the difficulty in quantifying intake, and the lack of information on how to maintain milk production using a grazing system have prevented

many dairy farmers from using pasture in their systems (Parker et al., 1992; Kolver and Muller, 1998; Soriano et al., 2001; White et al., 2002). Lower milk yields from pasture-based 
systems have been attributed to several factors including limited supplementation levels, an imbalance in pasture constituents supply (i.e. protein and carbohydrate), increased nutrient needs for walking and grazing, and the inability of the lactating cow to consume enough pasture DM to support high levels of production (NRC, 2001).

Rotational grazing systems provide for forages that are generally lower in NDF and higher in RDP than the more mature forages supplied as hay or silage (Van Vuuren et al., 1991; Hoffman et al., 1993; Holden et al., 1994, 1995). Supplementing a pasture diet with a TMR, a feeding system increasingly referred to as a partial mixed ration (PMR), has reduced some of the challenges imposed by pasture-based diets. In addition to improved lactation performance, due in large part to increased total DMI, changes in ruminal fermentation and digestion (i.e. improved ruminal $\mathrm{pH}$ stability and increased $\mathrm{N}$ capture) from forage and energy sources present in PMR have been reported (Bargo et al., 2002b). These sources are typically lower in $\mathrm{CP}$ concentration and greater in effective fiber compared to pasture sources (NRC, 2001).

A number of studies conducted in the U.S. have compared animal performance of high-producing dairy cows on TMR vs. pasture-only diets (Kolver and Muller, 1998; Tucker et al., 2001), TMR vs. pasture plus concentrate (White et al., 2002; Washburn et al., 2002; Fontaneli et al., 2005), and TMR vs. TMR plus pasture (Soriano et al., 2001; Bargo et al., 2002a), but limited research is available evaluating the use of TMR with increasing levels of pasture supplementation. Dairy producers willing to transition from confinement to pastoral dairying may find this assessment extremely useful. To our knowledge, there are no published studies that examine animal performance under increasing TMR replacement with high-quality pasture grazing, an assessment of the extent to which TMR can be restricted 
without critically affecting lactation performance. Two experiments were conducted to evaluate the partial replacement of TMR by pasture on total DMI, milk production and composition, feed and milk fatty acid profiles, feed efficiency, BW and BCS changes, and blood metabolites (experiment 2 only). We hypothesized that cows fed a diet including some TMR-to-pasture combination may perform as well as, or even outperform, an allconfinement diet, as opposed to a linear decrease in animal performance as increasing levels of pasture complement TMR-restricted diets. Also, we hypothesized that the threshold in terms of significant losses in lactation performance under increasing pasture DMI conditions would fall within the TMR-pasture combinations tested.

\section{MATERIALS AND METHODS}

Two 8-week studies (each with $\mathrm{n}=30$ lactating Holstein cows) were conducted to evaluate lactation performance, total and pasture DM intake, and feed efficiency from cows fed different combinations of TMR and pasture.

\section{Experiment 1}

\section{Cows and Treatments}

Experiment 1 was conducted at the North Carolina State University Lake Wheeler Dairy Educational Unit, Raleigh, NC, from October 26 to December 17, 2004 (F2004). Thirty lactating Holstein cows were blocked by milk yield, parity, and days in milk (DIM). Cows averaged $32.4 \pm 2.5 \mathrm{~kg} / \mathrm{d}$ milk, $87.1 \pm 9.2$ DIM, $1.6 \pm 0.2$ lactations, $560.6 \pm 11.8 \mathrm{~kg}$ body weight (BW), and $3.03 \pm 0.06$ body condition score (BCS) at the initiation of F2004. After blocking and random allocation, cows were assigned to either a nutritionally-balanced TMR fed ad-libitum (100T, $\mathrm{n}=6$, full nutrient positive control, no access to pasture) or one of the following three formulated TMR-restricted dietary treatments $(n=8)$ with access to 
pasture: a) 85\% TMR-restricted diet (85T); b) 70\% TMR-restricted diet (70T); and c) 55\% TMR-restricted diet (55T). All cows were confined and fed a TMR diet before the initiation of the trial. Although the TMR restriction was based on the average 48-h TMR consumption from all thirty cows before the initiation of the experiment, cows on the $100 \mathrm{~T}$ treatment had access to ad-libitum offering throughout the trial assuring a daily refusal of approximately $10 \%$. The experiment was conducted as a randomized complete block design with repeated measurements, with an adaptation period that included the first 3 weeks and a sampling period that included the last 5 weeks.

\section{Confinement and Pasture Feeding Management}

After training cows to individual feeding gates, assigned TMR amounts were offered individually, twice daily, using Calan ${ }^{\circledR}$ feeding stations (American Calan Inc., Northwood, $\mathrm{NH}$ ) in a free-stall barn. One-third of the daily amount was offered after the a.m. milking and two-thirds after the p.m. milking. The same corn-silage based TMR was fed throughout the study. The TMR intake for each treatment was calculated daily from the difference between the amount fed and feed refusals using a Uebler ${ }^{\circledR}$ mixing cart (Uebler Manufacturing, Vernon, NY). All cows had access to water in the barn, and the 100T group had access to a dirt lot for daily exercise. Total mixed ration mean and median particle size were 3.15 and $1.90 \mathrm{~mm}$ (particle size $>1.7 \mathrm{~mm}=48 \% ;<1.7$ but $>0.5 \mathrm{~mm}=36 \% ;<0.5 \mathrm{~mm}$ $=16 \%)$ according to the procedure of Fisher et al. (1988), after dry sieving (USA Standard Testing Sieve, Fisher Scientific Co.) freeze-dried TMR samples (3 replicates of approximately $15 \mathrm{~g}$ DM each).

The three grazing groups had access to annual ryegrass (Lolium multiflorum Lam.;

var. Marshall, seeded September 13, 2004) and grazed together as a single group $(\mathrm{n}=24)$. 
Annual ryegrass was selected as the grazing source because of the excellent nutritional characteristics (quality and palatability) and agronomic performance (yield, length of growing season, seeding establishment and persistence under close grazing) of this coolseason grass in the southeastern U.S. (Ellis and Lippke, 1976; Tucker et al., 2001). Cows grazed between the morning and afternoon milking for approximately $7 \mathrm{~h} / \mathrm{d}(0800$ to $1500 \mathrm{~h})$, after which they were milked and housed overnight together with the 100T group. One field of 4.86 ha (paddock 1), the center of which is about $350 \mathrm{~m}$ from the feeding barn, was divided into two equal paddocks was used during the trial. In addition, because of slower fall growth after a first grazing cycle, a second pasture (paddock 2, $4.1 \mathrm{ha}$ ), approximately $600 \mathrm{~m}$ from the feeding barn, was used for $9 \mathrm{~d}$ during this study. With the aid of temporary electrified fencing, cows were offered a fresh strip of pasture every morning, averaging 0.18 ha; or $75.3 \mathrm{~m}^{2}$ per cow during $51 \mathrm{~d}$. Paddocks 1 and 2 were fertilized with $\mathrm{N}$ before the beginning of the experiment (October 4, 2004) with 32.6 and $48.4 \mathrm{~kg} \mathrm{~N} / \mathrm{ha}$, respectively, and were spray irrigated in November of 2004 with lagoon waste delivering the equivalent of 22.6 and $7.8 \mathrm{~kg} \mathrm{~N} / \mathrm{ha}$, respectively. Pasture samples clipped to ground level that were handseparated were used for botanical composition and morphological assessment.

In order to sustain nutritive value and to maximize pasture DMI, the amount of pasture offered was approximately 3 times greater than the pasture DMI targeted for the 55T group (Bargo et al., 2003). To achieve the daily targeted pasture allowance (approximately 9 $\mathrm{kg} \mathrm{DM} /$ cow x $3=27 \mathrm{~kg} \mathrm{DM} / \mathrm{cow}$ ), pre-grazing herbage mass was measured once weekly to adjust the size of the daily strips to control the amount of pasture offered. Herbage mass per hectare was assessed by clipping twenty four, $0.25-\mathrm{m}^{2}$ quadrants to ground level. The forage was dried at $60^{\circ} \mathrm{C}$ in a forced air oven until constant weight to determine DM content. These 
measurements were used to estimate pasture DMI.

\section{Pasture Intake Measurements}

Pasture DMI was measured during weeks 2 (November 5), 3 (November 12), 4 (November 19), 6 (December 3), and twice during week 8 (December 16 and 17). Pasture DMI estimates were based on a herbage mass disappearance method (HDM) and calculated from the difference between pre- and post-grazing herbage mass (Lantinga et al., 2004). Because pre- and post-grazing measurements were taken within a short window of time (24 h), growth during this period was ignored (Meijs et al., 1982). Every week, one cow was randomly selected from each treatment that had access to pasture and assigned at random to an individual plot. Sampling from pre- and post-grazing herbage mass was done by clipping eight $0.25-\mathrm{m}^{2}$ quadrants in each plot before and immediately after the grazing period. Clippings were taken to ground level with the aid of battery-powered sheep-shearing heads avoiding soil contamination. Clippings were made at the same time of the day (Orr et al., 2001), approximately 3 p.m., on two consecutive days, positioning the post-grazing frame approximately $10 \mathrm{~cm}$ from the previous, pre-grazing frame. Plot size varied according to herbage mass and averaged $144.6 \mathrm{~m}^{2}$ per cow. Converted to a per-hectare basis, means $( \pm$ SE) of herbage mass offered and refused were 3,216 $( \pm 291)$ and 2,737 $( \pm 268) \mathrm{kg} \mathrm{DM} / \mathrm{ha}$, respectively. Herbage mass offered ranged from 2,251 kg/ha (week 2) to 4,154 kg/ha (week 8), and residual herbage mass ranged from $1,678 \mathrm{~kg} /$ ha (week 2) to 3,496 kg/ha (week 8). Harvested samples were placed in plastic bags, kept on ice, and transported to the laboratory where they were weighed and subsequently dried at $60^{\circ} \mathrm{C}$ in a forced air oven until constant weight to determine DM content. Before drying, two subsamples were obtained from each quadrant and composite samples of these for each grazing treatment were used for a) 
separation into green ryegrass leaf, green ryegrass stem, and other plant fractions, brown tissue and weeds, and b) freeze-dried for later characterization of nutritive value.

Although no regression relationship was established due to the narrow spread of estimates, herbage mass was further characterized using a plate meter and an electronic capacitance probe (Design electronics, Palmerston North, New Zealand). Leaf/stem ratios provided for additional information in terms of pasture management and characterization. A $0.2-\mathrm{m}^{2}$ circular acrylic plate meter was used, similar to the one used by Vartha and Matches (1977). The plate exerted a pressure on the pasture canopy of $6.0 \mathrm{~kg} / \mathrm{m}^{2}$. The disk was dropped from a height of $1.5 \mathrm{~m}$ above ground level to settle on the sward. For each measurement, the lower tip of the rod was placed centrally on the ground within the frame area used later for the clipping method. Measurements were made previous to clipping at every assigned site, in order from the least to the most destructive method (i.e. first was the plate meter, followed by pasture probe and clipping).

An animal performance method (APM) based on the difference between the energy requirements for a given animal performance (including energy requirements for milk production, maintenance, BW changes, walking, and grazing) and energy supplied by the TMR provided for alternative estimates of pasture DMI (Baker, 2004). Equations were provided by NRC (2001), as outlined by Macoon et al. (2003). Energy requirements included $\mathrm{NE}$ of lactation $\left(\mathrm{NE}_{1}, \mathrm{Mcal} / \mathrm{d}\right)$ requirements for: 1) maintenance $\left.\left(\mathrm{NE}_{l} \mathrm{M}\right) ; 2\right)$ lactation $\left(\mathrm{NE}_{1} \mathrm{~L}\right)$; 3) BW changes $\left(\mathrm{NE}_{1} \mathrm{BW}\right)$; 4) walking activity $\left(\mathrm{NE}_{1} \mathrm{~W}\right)$; and 5) grazing activity $\left(\mathrm{NE}_{1} \mathrm{G}\right)$. Briefly, maintenance requirements were calculated based on $\mathrm{BW}$ and lactation number, namely, $\mathrm{NE}_{1} \mathrm{M}=1.2 *\left(0.080 * \mathrm{BW}^{0.75}\right)$ for first-lactation cows, $\mathrm{NE}_{1}, \mathrm{M}=1.1 *\left(0.080 * \mathrm{BW}^{0.75}\right)$ for second-lactation cows, and $\mathrm{NE}_{1} \mathrm{M}=0.080 * \mathrm{BW}^{0.75}$ for third or greater lactation cows. 
Lactation requirements were calculated based on daily milk yields and milk fat content, namely, $\mathrm{NE}_{1} \mathrm{~L}=$ milk yield, $\mathrm{kg} / \mathrm{d} *(0.3512+[0.0962 * \%$ milk fat $])$. Energy from $\mathrm{BW}$ changes was reported as either extra energy required or added to that provided by diet, depending on $\mathrm{BW}$ gain or loss throughout the study, respectively (daily $\mathrm{BW}$ gain $=5.12 \mathrm{Mcal} / \mathrm{kg} \mathrm{BW}$; whereas average daily $\mathrm{BW}$ loss $=4.92 \mathrm{Mcal} / \mathrm{kg} \mathrm{BW}$ added to that provided by dietary intake). Daily walking activity included walking to the plot and back to the barn. It was calculated using an estimate for horizontal walking of $0.62 \mathrm{cal} /\left(\mathrm{kg} \mathrm{BW}^{*} \mathrm{~m}\right)$ provided by AFRC (1993). Distances walked to each plot ranged from 195 to $636 \mathrm{~m}$ (one way), and were measured with the aid of GPS technology (TSCe field device with a PRO XRS receiver and Trimble Survey Controller software, Trimble Navigation Limited, Sunnyvale, CA). Energy required for grazing was calculated based on grazing time and $\mathrm{BW}$, namely, $\mathrm{NE}_{1} \mathrm{G}=1.2$ kcal*grazing time, $\mathrm{h}^{*} \mathrm{BW}^{0.75}$ (Rochinotti, 1998). Although grazing time was not measured, it was calculated assuming a mean intake rate of $1.96 \mathrm{~kg} \mathrm{DM} / \mathrm{h}$ (Barrett et al., 2001) for measured pasture DMI using biomass disappearance. Total $\mathrm{NE}_{1}$ requirements were obtained by summing $\mathrm{NE}_{1} \mathrm{M}, \mathrm{NE}_{1} \mathrm{~L}, \mathrm{NE}_{1} \mathrm{BW}, \mathrm{NE}_{1} \mathrm{~W}$, and $\mathrm{NE}_{1} \mathrm{G}$. The $\mathrm{NE}_{1}$ from pasture intake was estimated as total $\mathrm{NE}_{1}$ requirements minus $\mathrm{NE}_{1}$ supplied by TMR intake.

\section{Sample Collection and Analyses}

In addition to ground-level samples collected every week from pre- and post-grazing herbage mass estimates, pasture samples were hand plucked twice a week at a height that simulated the animal diet. Samples were stored at $-20^{\circ} \mathrm{C}$, and subsequently freeze-dried. Weekly composites were ground in a Wiley mill (Thomas Scientific, Swedesboro, NJ) to pass through a 1-mm sieve. Freeze-dried weights were used to calculate dry matter (DM). Samples were analyzed for organic matter $(\mathbf{O M})$ and ash, and results are presented on a DM 
basis. Total $\mathrm{N}$ was determined by Autoanalyzer (AOAC, 1990) and multiplied by 6.25 to estimate crude protein (CP). Neutral detergent fiber (NDF) and acid detergent fiber (ADF) were sequentially analyzed using an Ankom fiber extractor (Ankom Technologies, Fairport, NY) as described by Van Soest et al. (1991). Concentrations of NDF were adjusted for residual ash, and heat-stable $\alpha$-amylase was omitted. Similarly, concentrations of ADF were determined adjusting for residual ash. Non-protein N (NPN) was determined according to Licitra et al. (1996). The remaining $B_{1}, B_{2}, B_{3}$, and $C$ fractions (Van Soest, 1994) were determined with neutral and acid detergent solutions with the residues analyzed for $\mathrm{N}$ concentration (AOAC, 1990). Nitrogen in the TMR and grazed forage was divided into NPN (fraction $A$ ), soluble protein $\left(B_{1}\right)$, insoluble protein that was soluble in neutral detergent $\left(B_{2}\right)$, protein that was insoluble in neutral detergent but soluble in acid detergent $\left(\mathrm{B}_{3}\right)$ and protein that was insoluble in acid detergent $(\mathrm{C})$. Fractions $\mathrm{B}_{1}, \mathrm{~B}_{2}$, and $\mathrm{B}_{3}$ are true protein fractions with decreasing solubility. Fraction $\mathrm{C}$ is assumed to be unavailable to the animal due to the resistance of this fraction to microbial and mammalian enzymatic breakdown (Licitra et al., 1996). Fractions $A$ and $B_{1}$ are soluble in phosphate-borate buffer and are rapidly degraded in the rumen. Fraction $B_{2}$ is fermented in the rumen at lower rates than buffer-soluble fractions, and some $\mathrm{B}_{2}$ fraction has been reported to escape to the lower gut. Fraction $\mathrm{B}_{3}$ is degraded at even lower rates due to its association with cell wall, thus a larger proportion of $B_{3}$ is believed to escape the rumen (Van Soest, 1994).

In vitro true dry matter digestibility (IVTDMD) was determined by placing $0.25-\mathrm{g}$ samples in acetone-soaked Ankom bags (Ankom Technologies, Fairport, NY). Samples were incubated in vitro in an Ankom II Daisy batch analyzer for a period of $48 \mathrm{~h}$ in a solution containing $1600 \mathrm{ml}$ of McDougal's buffer (Tilley and Terry, 1963) and $400 \mathrm{ml}$ of strained 
ruminal fluid. A cannulated mature Hereford steer fed mixed alfalfa (Medicago sativa L.) and orchardgrass (Dactylis glomerata L.) hay served as the donor animal. Microbial residues were removed from indigestible residues by extraction with a neutral detergent solution. In addition, pasture and TMR samples were submitted to the North Carolina Forage Testing Laboratory for mineral analysis (NC Department of Agriculture and Consumer Services, Raleigh, NC). All pasture samples were scanned using a near-infrared reflectance (NIR) spectrophotometer (Model 5000 Perstorp Analytical, Silver Spring, MD). Once the pasture samples were analyzed chemically, all results $(\mathrm{n}=95, \mathrm{H}$ statistic $=0.031)$ were used to develop calibration equations. Pasture nutrient composition was determined both from samples that were hand plucked and those clipped to ground level. Calibration and validation statistics are presented in Table 1. Summary statistics are comparable with those reported by Fisher et al. (1999, 2002), Redfearn et al. (2002), and Griggs et al. (2005) for IVTDMD of tall fescue, alfalfa, annual ryegrass, and orchardgrass, respectively.

Total mixed ration samples were taken once a week, stored at $-20^{\circ} \mathrm{C}$, and subsequently freeze-dried. Biweekly composites were chemically analyzed following similar procedures as described previously for pasture samples. However, concentrations of NDF and ADF of these samples were not adjusted for residual ash (AOAC, 1990, Official Method 973.18). Also, heat-stable $\alpha$-amylase was added to the NDF procedure.

All cows were milked twice daily at 0600 and $1700 \mathrm{~h}$, and milk production was recorded at each milking during the entire 8-week period (Westfalia Dairy Plan, Westfalia Surge, Inc. Naperville, IL). Individual milk samples collected weekly were analyzed for concentrations of fat, protein, lactose, milk urea nitrogen (MUN), and somatic cell counts (SCC) by the regional Dairy Herd Improvement laboratory (United DHIA, Blacksburg, VA) 
using infrared spectrophotometry (Fossomatic 360, Foss Electronic, Slangerupgade, Denmark). Weighted composite milk samples from a.m. and p.m. milkings, as well as pasture and TMR samples, were analyzed for fatty acid (FA) composition, including conjugated linoleic acids (CLA) using gas-liquid chromatography (model CP 3380; GC Varian, Walnut Creek, CA). Milk samples (2 ml) were methylated (Kramer et al., 1997) and fatty acid methyl esters (FAME) were determined. Separation was achieved using a CP-Sil 88 capillary column (100 m x $0.25 \mathrm{~mm} \times 0.2-\mu \mathrm{m}$ film thickness; Chrompack, Middleburg, The Netherlands). The column was operated at $70^{\circ} \mathrm{C}$ for $4 \mathrm{~min}$, then temperatureprogrammed at $13^{\circ} \mathrm{C} / \mathrm{min}$ up to $125^{\circ} \mathrm{C}$, held there for $27 \mathrm{~min}$, programmed at $8^{\circ} \mathrm{C} / \mathrm{min}$ up to $215^{\circ} \mathrm{C}$, and held there for $31 \mathrm{~min}$ for a total run time of $80 \mathrm{~min}$. Peak identity was verified by comparing peak retention times of samples to known methylated FA standards which included CLA. The CLA isomers reported are cis-9, trans-11 and trans-10, cis-12 $\mathrm{C}_{18: 2}$. The concentration of each FA was calculated by dividing the area under the corresponding FA peak by the sum of the areas under the total FA peaks (for milk samples, $\mathrm{C}=\mathrm{C}_{6}$ to $\mathrm{C}_{22}$; for TMR and pasture samples, $\mathrm{C}=\mathrm{C}_{16}$ to $\mathrm{C}_{18: 3}$ ). Cows were weighed on two consecutive days at 3 p.m. during weeks 1 and 5 to 8 . The same weeks, body condition of the cows was scored by an experienced, independent observer using the five-point scale $(1=$ emaciated, 5 = obese; Wildman et al., 1982), using 0.25-point increments.

\section{Experiment 2}

\section{Cows, Treatments, and Feeding Management}

Experiment 2 was also conducted at the North Carolina State University Lake Wheeler Dairy Educational Unit, Raleigh, NC, from March 22 to May 13, 2005 (S2005). Thirty lactating Holstein cows were blocked by milk yield, parity, and DIM and averaged 
$36.6 \pm 1.5 \mathrm{~kg}$ milk, $125.7 \pm 6.7 \mathrm{DIM}, 1.9 \pm 0.2$ lactations, $607.3 \pm 11.9 \mathrm{~kg} \mathrm{BW}$, and $2.88 \pm$ $0.06 \mathrm{BCS}$ at the initiation of S2005. Treatments, allocation of cows to treatments, and experimental design were as described previously for experiment 1, F2004.

Total mixed ration and pasture management were similar to that of F2004 and has been described earlier. Cows grazed on paddock 1 (4.86 ha) throughout the experiment (46 d) and were offered a fresh strip of pasture every morning, averaging a daily allotment of 0.15 ha or $63.3 \mathrm{~m}^{2}$ per cow. Pasture 1 received no supplemental $\mathrm{N}$ during the spring of 2005 . Botanical composition and annual ryegrass morphological assessment were conducted as noted for F2004.

\section{Pasture Intake Measurements and Sample Collection and Analyses}

Pasture DMI was measured once a week during the 8-week trial of S2005 as reported for F2004. Plot size varied according to herbage mass and averaged $107.7 \mathrm{~m}^{2}$ per cow. Converted to a per-hectare basis, herbage mass offered and refused were 4,359 ( \pm 407$)$ and 4,066 ( \pm 372$) \mathrm{kg} \mathrm{DM} / \mathrm{ha}$, respectively. Herbage mass offered ranged from $2,843 \mathrm{~kg} / \mathrm{ha}$ (week 6) to $6,075 \mathrm{~kg} / \mathrm{ha}$ (week 8), and herbage mass refused ranged from $2,772 \mathrm{~kg} / \mathrm{ha}$ (week 6) to $5,458 \mathrm{~kg} / \mathrm{ha}$ (week 8). Harvested samples were handled as noted for F2004. Chemical analyses of forage, TMR, and milk samples were conducted according to the procedures described previously for F2004. Further, BW and BCS were conducted as described for F2004.

Blood samples were collected from coccygeal vessels during weeks 1 and 5 to 8 before the p.m. milking. Samples were collected into $20-\mathrm{ml}$ evacuated tubes containing sodium heparin; and 10-ml evacuated tubes containing potassium oxylate-sodium fluoride (for glycolytic-inhibiting purposes) and immediately placed in ice. Samples were centrifuged 
at $3000 \mathrm{x} g$ for 15 minutes at $4^{\circ} \mathrm{C}$. Plasma was analyzed for glucose (YSI 2700 Select, Yellow Springs Instrument Co., Inc., Yellow Springs, OH), urea N (Technicon AutoAnalyzer II, Technicon Industrial method No. 334-74A/A, Technicon Industrial Systems, Tarrytown, NY), and non-esterified fatty acids (NEFA; Wako NEFA C kit No. 994-75409 E, Wako Chemicals USA, Inc., Richmond, VA).

\section{Statistical Analyses (Experiments 1 and 2)}

Variables measured (milk production, milk constituents, milk fatty acid composition, pasture and total intakes, blood metabolites) were analyzed according to a randomized complete block design using the PROC MIXED procedure of SAS (2002). The model included the fixed effects of treatment in addition to a random residual error term. For the S2005 study, the milk and milk composition data from one cow on the 70T treatment was removed from the model due to high SCC affecting overall lactation performance. For each variable analyzed, covariates for pretreatment milk yield, DIM, parity, SCC, BW, and BCS

were included and kept in the model when significant $(P<0.05)$. Least squares means and SEM are reported for all data. When significant effects $(P<0.05)$ due to dietary treatments were detected, mean separation was conducted using the PDIFF option in SAS (2002).

\section{RESULTS AND DISCUSSION}

Due to similarities of the overall objectives, variables measured, sampling protocols, and experimental design, the results of both studies (and the corresponding discussion) are presented here.

\section{Weather data}

Average daily temperatures at $2-\mathrm{m}$ height and at soil level were 21.7 and $24.4{ }^{\circ} \mathrm{C}$; 16.7 and $20.3{ }^{\circ} \mathrm{C} ; 11.9$ and $14.6{ }^{\circ} \mathrm{C}$; and 8.5 and $9.4^{\circ} \mathrm{C}$ for September, October, November, 
and December (first 18 days), respectively, with overall 2-m and soil average temperatures of 11.4 and $13.4^{\circ} \mathrm{C}$ for the duration of the F2004 trial (Experiment 1). Precipitations during these months were $113.0,36.2,80.1$, and $28.8 \mathrm{~mm}$, and accumulated a total of $108.9 \mathrm{~mm}$ during the duration of the trial. Likewise, $2-\mathrm{m}$ and soil daily temperatures were 9.1 and 8.5 ${ }^{\circ} \mathrm{C}$; 15.8 and $16.6^{\circ} \mathrm{C}$; and 16.7 and $19.0{ }^{\circ} \mathrm{C}$ for March, April, and May (first 13 days), respectively, with overall $2-\mathrm{m}$ and soil average temperatures of 15.6 and $16.4^{\circ} \mathrm{C}$ for the duration of the S2005 trial (Experiment 2). Precipitations during these months were 9.9, 8.7, and $50.0 \mathrm{~mm}$, and accumulated a total of $62.2 \mathrm{~mm}$ during the duration of the trial (State Climate Office of North Carolina, NC CRONOS Database, data retrieval from Lake Wheeler Rd. Field Lab, Raleigh, NC).

\section{Dietary Nutrient Composition}

Nutrient compositions of the TMR were similar for both experiments (Table 2), and were relatively constant throughout both 8 -wk periods. Although TMR samples were collected every week and biweekly composites were analyzed, only means ( \pm SE) over the length of both studies are reported. The TMR was originally formulated to provide approximately $16 \%$ CP (38.8\% RUP, 6.1\% EE; NRC 2001). Conversely, the nutritive value of hand-plucked annual ryegrass samples varied throughout the 8 weeks during F2004 (Table 3) and S2005 (Table 4). Annual ryegrass in vitro true organic matter digestibility (IVTOMD) averaged 96.5\% in F2004 and 93.7\% in S2005. Although unexpectedly high, our results are in agreement with findings reported by Cammell et al. (1983) and Corbett and Pickering (1983), where IVTOMD amounted to $94 \%$ for perennial ryegrass, and $96 \%$ for Reed canarygrass (Phalaris arundinacea), respectively.

As the fall grazing season progressed, pasture DM concentration increased from 
$13.9 \%$ (week 1) to $21.1 \%$ (week 8 ). Pasture CP for this period ranged from 31.9 to $21.6 \%$ (DM basis), the former greater value is primarily in response to $\mathrm{N}$ fertilization applied before the initiation of F2004. The CP concentration of annual ryegrass during F2004 decreased markedly from weeks 1 to 4 , followed by a slight increase in week 5 in accordance with the timing of $\mathrm{N}$ application and a gradual decline thereafter (Figure 1). In a similar fashion, although during the spring and summer, Bargo et al. (2002a) observed four peaks of CP concentration in a smooth bromegrass/orchardgrass mixed pasture in coincidence with applications of $50 \mathrm{~kg} \mathrm{~N} / \mathrm{ha}$ that had been applied a week in advance. In addition, the decrease in pasture $\mathrm{CP}$ concentration may have been due to either an increase in the proportion of stems (typically with lower CP concentrations than leaves; Minson, 1990) or a decrease of CP in leaf and stem fractions (Lyttleton, 1973), or both during the fall grazing season. At the initiation of grazing (late October, 2004), 52.6 and $15.1 \%$ of the herbage mass was leaf and stem of ryegrass, respectively, with $32.3 \%$ of the herbage mass classified as other, predominantly winter annual weeds such as henbit (Lamium amplexicaule) and common chickweed (Stellaria media). The leaf/stem ratio, defined by the ratio of blade weight to the sum of sheath, stem, and inflorescence weight (DM basis) was 3.48. By mid December, 44.7 and $38.2 \%$ of the herbage mass was leaf and stem of ryegrass (1.17 leaf/stem ratio), respectively, with $17.1 \%$ of the herbage mass classified as other (Table 5 and Figure 2). Dry matter and relative constituent proportioning in grasses can be explained by the leaf/stem ratio, a commonly used index to describe canopy architecture and its relationship to diet selection and intake (Smart et al., 2006).

Similar to F2004, DM concentration increased from $16.5 \%$ (week 1) to $25.7 \%$ (week 8) during the spring grazing season. Pasture $\mathrm{CP}$ for this period ranged from 11.8 to $21.8 \%$ 
(DM basis). For cool-season grasses during the spring season, the fastest rate of decline in $\mathrm{CP}$ concentration with advancing maturity occurs in early stages with immature forage and the rate of decline slows as the pasture becomes more mature (Fick and Onstad, 1988). The CP concentration during S2005 decreased markedly from weeks 1 to 5, and remained relatively constant thereafter. After summarizing the results of three experiments, Minson (1990) reported a $2.5 \mathrm{~g} / \mathrm{kg} \mathrm{DM} \mathrm{d} \mathrm{d}^{-1}$ decrease in annual ryegrass CP concentration with advancing age, although the rates of decline have been proven to vary considerably with available soil N (Buxton and Mertens, 1995) and plant morphology (i.e. leaf/stem ratios, as described earlier). At the initiation of grazing (late March, 2005), 37.8 and $28.1 \%$ of the herbage mass was ryegrass leaf and stem, respectively (1.35 leaf/stem ratio), with $34.0 \%$ of the herbage mass classified as other, predominantly as dead tissue remaining from winter dormancy. By mid May, 9.4 and $65.2 \%$ of the herbage biomass was annual ryegrass in leaf and stem, respectively (0.14 leaf/stem ratio), with $25.4 \%$ of the herbage mass classified as other (Table 6 and Figure 3).

The TMR offered in our study contained approximately $27 \%$ corn silage and $13 \%$ alfalfa silage (DM basis, Table 2). Ensiling causes remarkable changes in the partitioning of $\mathrm{N}$, causing a large proportion of the protein $\mathrm{N}$ present in fresh forage to be converted to NPN (Tamminga, 1986). Although $\mathrm{N}$ partitioning was not analyzed for individual TMR ingredients, NPN in silages can account for 50 to 80\% of total N (Hughes, 1970; McDonald, 1982), thus allowing for relatively large quantities of NPN in the TMR offered. Although quantification of different $\mathrm{CP}$ fractions has been addressed for a number of feedstuffs, it has not been extensively conducted in fresh forages (Elizalde et al., 1999). Pasture NPN ranged from 15.4 to $25.7 \%$ in F2004 and from 9.6 to $13.6 \%$ in S2005. The latter are in agreement 
with NPN values reported by Tamminga (1986) for Italian ryegrass during the spring (NPN was approximately $10 \%$ of $\mathrm{CP}$ ), but are somewhat lower than those reported by Elizalde et al. (1999) for three cool season grasses (bromegrass, endophyte-free and endophyte-infected tall fescue) which averaged $22.2 \%$ of $\mathrm{CP}$ during the spring. Non-protein $\mathrm{N}$ typically comprises 10 to $30 \%$ of $\mathrm{N}$ in fresh forages, most of it present in nucleic acids, peptides, amino acids, amides, and occasionally nitrate (Tamminga, 1986; Buxton and Mertens, 1995).

Reducing N fertilization of pastures (i.e. S2005 compared to that of F2004) reduces CP concentration and results in a smaller proportion of NPN (Wilman and Wright, 1983), influencing $\mathrm{N}$ solubility and suggesting that ruminal $\mathrm{CP}$ degradability may also be affected (Sanderson and Wedin, 1989; Van Vuuren et al., 1991).

Fraction $\mathrm{B}_{2}$ was the largest pasture $\mathrm{CP}$ fraction throughout both studies and ranged from 37.3 to $48.0 \%$ of CP in F2004 (Table 3) and from 44.0 to $48.2 \%$ of CP in S2005 (Table 4). In agreement with our findings, Elizalde et al. (1999) reported similar spring $B_{2}$ values for fresh forages (42.6, 48.5, and 46.5\% of CP for bromegrass, endophyte-free and endophyteinfected tall fescue, respectively). Overall, $\mathrm{CP}$ and fiber composition, but not $\mathrm{CP}$ values, were affected more by forage species than by maturity (Elizalde et al., 1999). A similar pattern was observed with annual ryegrass in this study.

\section{Pasture and Total Nutrient Intakes}

Daily pasture DMI in F2004 only exhibited a trend $(P=0.12)$ for greater intakes for the 55T group, followed by $70 \mathrm{~T}$ and $85 \mathrm{~T}(8.7,6.8$, and $4.5 \mathrm{~kg} \mathrm{DM}$, respectively) (Table 7). The lack of significance was primarily due to variation among cows within grazing groups. Consequently, CP, NDF, and NE intakes from pasture exhibited the same patterns. Also, a similar trend $(P=0.10)$ was observed for total DMI as a percent of BW. Total daily DM, 
NDF, and NE intakes, but not $\mathrm{CP}$ intakes, were greatest $(P<0.05)$ for 100T compared to all three grazing groups. Total CP intake remained unaffected by dietary treatments. Although total intakes for the three grazing groups were lower than the TMR group, pasture CP concentration during the last 5 weeks of F2004 averaged 23.7\%, compared to $15.8 \% \mathrm{CP}$ for the TMR. Total diet forage/concentrate ratios differed $(P<0.05)$ between dietary treatments, and ranged from 40:60 (100T) to 64:36 (55T) with increasing pasture. Gross feed efficiency [(4\% FCM yield, $\mathrm{kg}) /(\mathrm{DMI}, \mathrm{kg})]$, a measure of converting nutrients into animal product, remained unaffected across dietary treatments in F2004.

Pasture DMI in S2005 was clearly distinct between grazing groups (Table 8). Daily pasture DMI was greatest $(P<0.05)$ for $55 \mathrm{~T}(6.9 \mathrm{~kg})$ and lowest for the $85 \mathrm{~T}$ group $(2.2 \mathrm{~kg})$, while $70 \mathrm{~T}$ was intermediate $\left(4.2 \mathrm{~kg}\right.$ ). Consequently, $\mathrm{CP}, \mathrm{NDF}$, and $\mathrm{NE}_{1}$ intakes from pasture exhibited the same patterns. Total daily DMI (both in terms of $\mathrm{kg}$ and as a percent of BW) and $\mathrm{CP}, \mathrm{NDF}$, and $\mathrm{NE}_{1}$ intakes were greatest $(P<0.05)$ for $100 \mathrm{~T}$ compared to all three grazing groups. Pasture CP concentration during the last 5 weeks of S2005 averaged 13.9\% (compared to 23.7\% CP for the same period in F2004). Total diet forage/concentrate ratios differed $(P<0.05)$ between dietary treatments, and ranged from 40:60 (100T) to 60:40 (55T) with increasing pasture. Gross feed efficiency was greater $(P<0.05)$ for all three grazing groups compared to 100T. Compared to our gross feed efficiency data, Bargo et al. (2002a) reported entire-lactation gross feed efficiencies ( $3.5 \% \mathrm{FCM})$ of $1.25,1.23$, and 1.37 for lactating cows fed pasture plus concentrate, pasture plus TMR (approximately 70\% TMR and $30 \%$ pasture), and TMR, respectively.

Pasture DMI reported in Tables 7 and 8 were estimated using a pasture-based technique (HDM) that estimates pasture DMI by difference between herbage mass offered 
(i.e. pre-grazing herbage mass) and herbage mass refused (i.e. post-grazing herbage mass). An animal performance (APM) can be used based on the difference between the energy requirements for a given animal performance and energy supplied by the TMR (Figures 4 and 5). Studies comparing different techniques for estimating forage intake of lactating dairy cows on pasture have been reported (Reeves et al., 1996; Macoon et al., 2003; Smit et al., 2005). Burns et al. (1994) cautioned that there are a number of difficulties associated with each technique of estimating pasture DMI. Overestimating (assuming that all forage removed is a consequence of cow removal by grazing) and underestimating (sward growth between pre- and post-grazing clippings) DMI, in addition to intensive sampling, are examples of limitations to the use of pasture-based techniques (Fisher, 1994). Regardless of the difficulties mentioned above, the use of a HDM for estimating pasture DMI has proven to be successful for rotational stocking and short grazing periods (Moore, 1996; Macoon et al., 2003; Fontaneli et al., 2005).

The APM provided biologically reasonable estimates of DMI of cows grazing rye/ryegrass or ryegrass/crimson clover/red clover mixed pastures (Macoon et al., 2003) and intensively-managed kikuyu (Pennisetum clandestinum) pastures (Reeves et al., 1996), provided all assumptions (i.e. pasture digestibility, BW changes, other) were known. In our study, biologically reasonable estimates of pasture DMI were also obtained using the APM. In F2004, estimates of daily pasture DMI using the HDM were greater than those obtained using the APM for the lowest TMR intake levels ( $8.7 \mathrm{vs.} 7.9 \mathrm{~kg}$ for $55 \mathrm{~T}$ and $6.8 \mathrm{vs} .6 .7 \mathrm{~kg}$ for 70T, respectively). Conversely, the APM provided a greater estimate of daily pasture DMI at the greatest level of TMR intake compared with the HDM (5.7 vs. $4.5 \mathrm{~kg}$, respectively). In S2005, estimates of daily pasture DMI using the HDM were consistently lower than 
estimates obtained from the APM (6.9 vs. 7.7, 4.2 vs. 5.7, and 2.2 vs. $4.3 \mathrm{~kg}$ for treatments 55T, 70T, and 85T, respectively). Reeves et al. (1996) reported that spring estimates of total daily DMI by HDM were lower than those predicted by APM at low supplementation levels (12.5 vs. 14.8 , and 10.4 vs. $12.9 \mathrm{~kg} \mathrm{DM} / \mathrm{d}$ for cows that remained unsupplemented or were supplemented with $3.0 \mathrm{~kg}$ concentrate, respectively), but were greater for those receiving 6.0 kg concentrate (10.5 vs. $7.8 \mathrm{~kg} \mathrm{DM} / \mathrm{d}$ ) (Reeves et al., 1996). The APM used by Reeves et al. (1996) was based on the difference between metabolizable energy (ME) supplied by grazing and concentrate supplementation (based on in vitro OM digestibility) and ME required (Ministry of Agriculture, Fisheries and Food, London, UK, 1975).

Estimates of pasture DMI using the HDM more closely approximated the estimates calculated based on $\mathrm{NE}_{1}$ requirements than did estimates obtained by the pulse-dose marker method using chromium-mordanted fiber as the external marker (Macoon et al., 2003). This indicates that appropriate estimates of pasture DMI could be obtained by using either the HDM or the APM. Also, estimates of pasture DMI by the HDM were positively correlated with those obtained using the APM ( $r=0.57$; Macoon et al., 2003). In our study, coefficients of determination $\left(\mathrm{r}^{2}\right)$ and standard errors of prediction $\left(\mathrm{S}_{\mathrm{xy}}\right)$ from HDM vs. APM were 0.26 and $2.96 \mathrm{~kg}$ DM for F2004, respectively; and 0.37 and $1.7 \mathrm{~kg}$ DM for S2005, respectively.

Total mixed ration intakes were kept high in accordance to what was offered (TMR was not replaced by pasture), but restricting TMR intake lowered total DMI. Bargo et al. (2002a) reported similar findings for mid-lactating Holstein cows offered pasture plus TMR. Despite having access to high-quality pasture, cows on a pasture plus TMR diet that were offered $17 \mathrm{~kg}$ DM of TMR daily consumed almost all of what was offered (15.5 kg DM consumed). Similarly, Soriano et al. (2001) reported TMR intakes 26.6, 17.5, and $20.3 \mathrm{~kg}$ 
$\mathrm{DM} / \mathrm{d}$ for cows offered unrestricted TMR, TMR plus access to pasture in the afternoon, or TMR plus access to pasture in the morning, respectively. In our study, instead of the formulated 45,30 , and $15 \%$ pasture, actual diets became 41,32 , and $21 \%$ pasture during the fall of 2004 and 35, 21, and $11 \%$ pasture during the spring of 2005 for diets 55T, 70T, and 85T, respectively. For the purpose of NE intake calculations, pasture was considered to yield 1.45 Mcal/kg DM based on NRC (2001) predictions for intensively managed cool-season grass pastures. The NE value reported by NRC is smaller than the one obtained using the Pennsylvania State University equation based on ADF concentration (Undersander et al., 1993).

\section{Milk Production and Composition}

In F2004, a trend $(P=0.06)$ was evident for greater daily milk yields for the treatments with greater TMR intake (85T and $100 \mathrm{~T}$ ) existed, but 4\% FCM was not affected by dietary treatment, and averaged $32.0 \mathrm{~kg} / \mathrm{d}$ (Table 9$)$. In S2005, milk yields were greater ( $P$ $<0.05$ ) for treatments $85 \mathrm{~T}$ and $100 \mathrm{~T}$ compared to treatments $55 \mathrm{~T}$ and $70 \mathrm{~T}$, establishing a clear distinction between groups that had access to the greatest amounts of TMR (Table 10). Fat-corrected milk, however, was greatest $(P<0.05)$ for 85 , followed by treatments $100 \mathrm{~T}$ and $55 \mathrm{~T}$, and smallest for $70 \mathrm{~T}$. The latter results were supported by a numerically greater milk fat concentration for 55T. Cows that consumed 100T in F2004 produced $14 \%$ more milk and 6\% more FCM than cows consuming 70T. Similarly, cows that consumed $100 \mathrm{~T}$ in S2005 produced $15 \%$ more milk and $9 \%$ more FCM than cows consuming $70 \mathrm{~T}$. Compared to our findings, cows offered unrestricted amounts of TMR produced 19\% more milk and 18\% more 3.5\% FCM than cows consuming a similar PMR offered in our study (Bargo et al., 2002a). The PMR diet offered by Bargo et al. (2002a) included 30\% pasture (7.5 kg/d), a 
predominantly bromegrass/orchardgrass mixed pasture. The greater differences in performance between both dietary treatments reported by Bargo et al. (2002a) are attributed to greater DMI in the TMR $(26.7 \mathrm{~kg} / \mathrm{d})$ and PMR $(25.2 \mathrm{~kg} / \mathrm{d})$ groups resulting in greater milk production from TMR (38.1 kg/d) but not from PMR (32.0 kg/d) compared to our 100T and 70T diets, respectively.

In F2004, milk fat concentration and daily yields of milk fat and protein were similar across treatments and averaged $3.87 \%, 1.26 \mathrm{~kg}$, and $0.96 \mathrm{~kg}$, respectively. Milk protein concentration, however, was greatest $(P<0.05)$ for $70 \mathrm{~T}$, followed by $100 \mathrm{~T}$, and lowest for $55 \mathrm{~T}$ and $85 \mathrm{~T}$. Although milk constituent concentrations were unaffected by treatment in S2005, milk fat $(P=0.06)$ and protein $(P<0.05)$ yields were increased for $85 \mathrm{~T}$ and $100 \mathrm{~T}$ compared to cows fed 55T and 70T. Similar to our findings in S2005, daily milk fat (3.30 vs. $3.35 \%)$ and milk protein (2.99 vs. $2.95 \%)$ concentrations did not differ, but fat yields (1.24 vs. $1.06 \mathrm{~kg})$ and protein yields $(1.13$ vs. $0.93 \mathrm{~kg})$ were greater for TMR than PMR, respectively (Bargo et al., 2002a). The differences in milk production between these two groups were attributed to differences in daily energy intake and to differences in energy maintenance which included walking and grazing activity. Based on equations developed by the NRC (2001), daily maintenance energy requirements for cows in the PMR group were 2.5 Mcal greater than cows fed TMR (Bargo et al., 2002a). Based on the NE concentration in milk and the extra daily activity in cows on the PMR, $61 \%$ of the milk difference $(3.7 \mathrm{~kg}$ ) was accounted for between cows on the PMR and TMR diets (Bargo et al., 2002a). In our study, daily maintenance energy requirements for cows in the F2004 grazing groups were increased by $0.97,0.85$, and $0.61 \mathrm{Mcal}$ for cows in 55T, 70T, and $85 \mathrm{~T}$, respectively, compared to cows on $100 \mathrm{~T}$. This potentially accounted for $1.4,1.1$, and $0.9 \mathrm{~kg}$ of milk for the 
corresponding grazing groups. Similarly, daily maintenance energy requirements for cows in the S2005 grazing groups were increased by $0.76,0.60$, and $0.43 \mathrm{Mcal}$ for cows on 55T, 70T, and 85T, respectively, compared to cows fed TMR exclusively. This accounted for 1.1, 0.9, and $0.6 \mathrm{~kg}$ of milk for cows on treatments $55 \mathrm{~T}, 70 \mathrm{~T}$, and $85 \mathrm{~T}$, respectively. It is likely some combination of increased activity and decreased energy intake accounted for much of the differences in milk production among dietary treatments reported in our study.

Milk urea $\mathrm{N}$ did not differ between dietary treatments and averaged $13.6 \mathrm{mg} / \mathrm{dl}$ in F2004 (Table 9), but in S2005 MUN was greatest $(P<0.05)$ for 100T $(14.1 \mathrm{mg} / \mathrm{dl})$ and lowest for all grazing groups, that averaged $9.7 \mathrm{mg} / \mathrm{dl}$ (Table 10). Milk urea $\mathrm{N}$ has been used as an indicator to monitor protein nutrition and excretion (Jonker et al., 1998, 2002). Typically, MUN values range from 10 to $15 \mathrm{mg} / \mathrm{dl}$ (Moore and Varga, 1996). Weekly variations of MUN in lactating cows that graze often mirror $\mathrm{CP}$ concentration patterns throughout the grazing season (Wittwer et al., 1999; Bargo et al., 2002a). Data from 82 dairy herds on pasture-based feeding systems reported high seasonal variation in bulk MUN (mean $=13.5 \mathrm{mg} / \mathrm{dl}$, ranging from 4.1 to $32.1 \mathrm{mg} / \mathrm{dl}$ ). The greatest values were reported during early spring (15.8 to $16.3 \mathrm{mg} / \mathrm{dl})$ and the lowest during late summer (9.9 to $10.2 \mathrm{mg} / \mathrm{dl})$. Crude protein concentrations averaged 16.5 in spring and $10.7 \%$ in the summer (Wittwer et al., 1999). Although dietary CP concentration is a key nutritional factor influencing MUN (Nousiainen et al., 2004), factors such as dietary CP intake, the proportion of rumen degradable and rumen undegradable protein, and protein/energy ratios in the diet have proven to affect MUN (Roseler et al., 1993; Baker et al., 1995). In our study, total daily CP intakes in F2004 did not differ between dietary treatments and averaged $4.0 \mathrm{~kg}$. Conversely, daily total CP intakes in S2005 were greatest $(P<0.05)$ for 100T $(4.0 \mathrm{~kg})$ compared to all 
three grazing groups that averaged $3.1 \mathrm{~kg}$.

\section{Milk Fatty Acid Composition}

The TMR fed to cows was relatively high in $\mathrm{C}_{18: 2}$ concentration, whereas the pasture was high in $\mathrm{C}_{18: 3}$ (Table 11). Compared to forages, where $\mathrm{C}_{18: 3}$ is the most abundant $\mathrm{FA}$, cereal grains (i.e. corn, barley, wheat, other) and oilseeds (i.e. soybean, sunflower, canola, other) contain a high proportion of $\mathrm{C}_{18: 2}$ (Schroeder et al., 2004). Decreasing the amounts of TMR and increasing the amounts of pasture fed decreased total dietary fat, decreased the proportion of $\mathrm{C}_{18: 1}$ and $\mathrm{C}_{18: 2}$, and increased the proportion of $\mathrm{C}_{18: 3}$ in the diets. Also, in $\mathrm{S} 2005$ a decrease in $\mathrm{C}_{18: 3}$ and a concomitant increase in cis-trans methylene interrupted isomers occurred in the annual ryegrass pasture as the season progressed (Table 11).

The FA content of pasture is often highly unsaturated (approximately 70 to $90 \%$ of total FA) with relatively large amounts of $\mathrm{C}_{18: 2}$ and $\mathrm{C}_{18: 3}$. The FA composition reported for annual ryegrass in our study fell within the range of values reported elsewhere. Data summarized by Schroeder et al. (2004) for some of the most commonly-used cool-season grasses ranged from 13.5 to $18.5 \mathrm{~g} / 100 \mathrm{~g}$ FA for $\mathrm{C}_{18: 2}$; and from 43.0 to $72.0 \mathrm{~g} / 100 \mathrm{~g}$ FA for $\mathrm{C}_{18: 3}$. Linoleic acid and $\mathrm{C}_{18: 3}$ were the predominant fatty acids in freshly-harvested perennial ryegrass (12 and 69\% of total FA, respectively, Kim et al., 2005). Oddly, annual ryegrass exhibited both the greatest $(31.1 \mathrm{~g} / \mathrm{kg}$ DM, harvested in November) and the lowest $(6.1 \mathrm{~g} / \mathrm{kg}$ DM, harvested in July) total FA concentration compared to other eight cool-season species (Dewhurst et al., 2001). Annual ryegrass had greater concentrations of total FA and $\mathrm{C}_{18: 3}$ during the early and late season compared to perennial ryegrass. Similar to what occurred in our study, fatty acids (particularly $\mathrm{C}_{18: 2}$ and $\mathrm{C}_{18: 3}$ ) declined when the regrowth interval was extended from 20 to 38 days (5 vs. 3 harvests, respectively) (Dewhurst et al., 2001). 
An increased supply of $\mathrm{C}_{16: 0}$ from the TMR resulted in the greatest $(P<0.05)$ concentration of $\mathrm{C}_{16: 0}$ in milk fat of cows in the 100T treatment (Tables 12 and 13). In F2004, the concentration of $\mathrm{C}_{18: 3}$ in milk fat was greatest $(P<0.05)$ for 55T, intermediate for 70T and 85T, and lowest 100T. Similarly, in S2005 the concentration of $\mathrm{C}_{18: 3}$ in milk fat was lowest for 100T $(P<0.05)$, but was greatest for cows that had access to pasture, that averaged $0.5 \mathrm{~g} / 100 \mathrm{~g}$ of total FA. The concentration of saturated FA in milk fat (the sum of $\mathrm{C}_{10: 0}, \mathrm{C}_{12: 0}, \mathrm{C}_{14: 0}, \mathrm{C}_{16: 0}$, and $\left.\mathrm{C}_{18: 0}\right)$ was greatest $(P<0.05)$ for 100T $(63.3 \mathrm{~g} / 100 \mathrm{~g} \mathrm{FA})$ in F2004, and was greatest $(P<0.05)$ for $85 \mathrm{~T}$ and $100 \mathrm{~T}(63.2 \mathrm{~g} / 100 \mathrm{~g} \mathrm{FA})$ in S2005. Conversely, the concentration of unsaturated FA (the sum of $\mathrm{C}_{18: 1}, \mathrm{C}_{18: 2}$, CLA, and $\mathrm{C}_{18: 3}$ ) was greatest $(P<0.05)$ for 55T and 70T for both seasons.

Long-chain polyunsaturated $\mathrm{FA}\left(\mathrm{C}_{18: 2}\right.$ and $\left.\mathrm{C}_{18: 3}\right)$ are subjected to biohydrogenation processes in the rumen (Kepler and Tove, 1967). The change in the FA profile of milk reported in our study is consistent with the practice of feeding stored vs. fresh forages, and has been attributed to the loss of precursor FA during the silage- or hay-making process (Dewhurst et al., 2001). Also, the change in the FA profile of milk from cows fed grainbased concentrates has been linked to the distinct nature of FA profiles reaching the rumen (Schroeder et al., 2004). Forage preservation, either by drying or ensiling, has been reported to reduce the concentration of total and polyunsaturated FA in forage DM (Dewhurst et al., 2003). Leaf tissues contain more FA than stem tissues, and because hay making is more damaging to leaves than silage making, the former results in greater FA losses (Dewhurst et al., 2006). For example, Aii et al. (1988) reported $C_{18: 3}$ concentrations in fresh ryegrass (40.1 $\mathrm{g} / 100 \mathrm{~g}$ total FA) that were reduced to $6.3 \mathrm{~g} / 100 \mathrm{~g}$ total FA when harvested as hay, but remained similar when harvested as haylage (36.4 g/100 g total FA). 
The concentration of cis-9, trans-11 CLA in milk fat was greatest $(P<0.05$ in F2004; $P=0.09$ in S2005) for 55T. In F2004, due to greater pasture DMI, forage/concentrate (F:C) ratios ranged from 64:36 for treatment 55T to 40:60 for treatment 100T; whereas in S2005, F:C ratios ranged from 60:40 for treatment 55T to 40:60 for treatment 100T. A tighter range in $\mathrm{F}: \mathrm{C}$ ratios could explain the lower cis-9, trans-11 CLA concentration and range across treatments that occurred in S2005. A considerable body of literature is available indicating that milk from grazing cows contains greater proportions of CLA and omega-3 FA compared with those fed conserved forages (Jahreis et al., 1997; Kelly et al., 1998; Dhiman et al., 1999; White et al., 2001a; Loor et al., 2003; Schroeder et al., 2003, 2005). In addition, milk from grazing cows contains more trans FA than milk from cows fed a TMR, due primarily to an increase in trans-11 $\mathrm{C}_{18: 1}$ concentration (Loor et al., 2003). Although numerous research studies indicate that CLA concentration in milk fat may be routinely increased from 5- to 10-fold (Palmquist, 2001), pasture-based diets have shown increased CLA concentrations in milk fat that range from approximately 2- (Jahreis et al., 1997; Schroeder et al., 2005) to 5-fold (Dhiman et al., 1999). Comparatively, our data showed only modest increases in the concentration of CLA isomers measured with increased pasture DMI: treatment 55T produced 38 and 17\% more (cis- 9, trans-11 CLA + trans-10, cis-12 CLA) than 100T in F2004 and S2005, respectively.

Common features for most of these studies were a) the substantial variation in CLA concentration among individual cows within treatment groups consuming the same diets and subjected to the same management regimen and b) the positive linear relationship established between CLA and trans-11 $\mathrm{C}_{18: 1}$. The individual range in CLA concentrations for cows fed a TMR was 2.4 to $7.0 \mathrm{mg} / \mathrm{g}$ of milk FA, but this range was 6.3 to $18.1 \mathrm{mg} / \mathrm{g}$ of milk FA when 
the cows were fed a pasture-only diet (Kelly et al., 1998). Similar findings were reported by White et al. (2001a) and Elgersma et al. (2004). The variation in CLA concentrations among individual cows has been attributed mainly to differences in rumen biohydrogenation and mammary $\Delta^{9}$-desaturase activity (Peterson et al., 2002). The positive linear relationship between CLA and trans-11 $\mathrm{C}_{18: 1}$ provides further evidence for a common origin of these two FA (Bauman and Griinari, 2001).

\section{Body Weights and Body Condition Scores}

In F2004, mean BW were lowest $(P<0.05)$ for treatment 55T, but initial (week 5) and final (week 8) BW did not differ among dietary treatments and averaged 571 and $576 \mathrm{~kg}$, respectively (Table 14). Body weight changes (BWC, week 8 minus week 5) were greatest $(P=0.09)$ for treatment $85 \mathrm{~T}(14.0 \mathrm{~kg})$, intermediate for groups $70 \mathrm{~T}(7.0 \mathrm{~kg})$ and $55 \mathrm{~T}(3.0$ $\mathrm{kg})$, and lowest for 100T $(-4.0 \mathrm{~kg})$. In contrast, in S2005 mean and final BW were similar among treatments, but initial (week 5) BW were greatest for treatment $100 \mathrm{~T}(626 \mathrm{~kg}$ vs. an average of $602 \mathrm{~kg}$ for cows that had access to pasture) (Table 15). Body weight changes were greatest $(P<0.05)$ for the groups that had access to pasture (mean $=20.0 \mathrm{~kg}$ ) compared to that of $100 \mathrm{~T}(-15.0 \mathrm{~kg})$.

In F2004, in agreement with the greatest BW gain, mean BCS based on a five-point scale $(1=$ very thin, $5=$ obese, Wildman et al., 1982$)$ was greatest $(P=0.10)$ for treatment $85 \mathrm{~T}$ (3.09) (Table 14). In S2005, BW gain was not necessarily reflected in high BCS. Furthermore, mean BCS was greatest $(P<0.05)$ for treatment 70T $(3.08)$ and lowest for treatment $85 \mathrm{~T}$ (2.92) (Table 15). A common feature to both studies included the association between greater BW loss $(-4.0$ and $-15.0 \mathrm{~kg})$ and greatest BCS change for 100T compared to the groups that had access to pasture. 
In a 4-wk study, Kolver and Muller (1998) reported BCS losses (-0.50) for high producing dairy cows ( $46.3 \mathrm{~kg}$ milk at the initiation of the study) consuming a pasture-only diet, whereas cows fed a TMR maintained BCS. Similarly, a 10-week study by Tucker et al. (2001) reported slight BCS losses (-0.09) for cows consuming a pasture-only diet, while cows fed a TMR increased BCS (0.42). In a 21-wk study by Bargo et al. (2002a), cows consuming pasture plus concentrate lost BCS $(-0.20)$, cows consuming pasture plus TMR maintained BCS (0.01), and cows consuming a TMR gained BCS (0.19). Washburn et al. (2002) reported that over the entire lactation, Holstein cows consuming a pasture-based diet exhibited lower BCS than Holsteins fed a TMR.

\section{Plasma Metabolites}

Plasma glucose concentration was greatest $(P=0.05)$ for $100 \mathrm{~T}$ and lowest for 55T and $85 \mathrm{~T}$ in week 5 , but remained similar across treatments during the weeks that followed (Table 16). This plasma glucose concentration pattern indicates a smaller discrepancy between energy demand and energy supply as the spring season progressed. Plasma NEFA concentrations, a measure of adipose tissue mobilization, did not differ between dietary treatments and averaged $231 \mathrm{meq} / \mathrm{L}$ in week 5 , but by week 8 all grazing groups were similar and lower $(P<0.05)$ compared with NEFA concentrations of treatment 100T. Concurrently, BW loss, calculated as final BW (week 8) minus initial BW (week 5), was greatest $(-15 \mathrm{~kg}$; $P<0.05$ ) for treatment $100 \mathrm{~T}$ compared to all three grazing groups (Table 15), indicating a greater body fat mobilization for cows on $100 \mathrm{~T}$ to support greater levels of milk production (Table 10). Plasma urea N, in accordance with CP intake (Table 8) and MUN data (Table 10), exhibited the same pattern for weeks 5 through 8 : the three grazing groups had lower ( $P$ $<0.05)$ PUN than treatment 100T. Kolver and Muller (1998) reported that the transition from 
high milk production $(46.3 \mathrm{~kg} / \mathrm{d})$ for cows fed a TMR to lower milk production for cows consuming an all pasture diet resulted in significant loss of body condition and live weight $(1.1 \mathrm{~kg} / \mathrm{d})$. Metabolic transition was reflected in increased plasma NEFA concentration (1044 vs. $284 \mathrm{meq} / \mathrm{L}$ during the transition phase; 684 vs. $304 \mathrm{meq} / \mathrm{L}$ during the final phase) and initially lower glucose concentrations (60 vs. $65 \mathrm{mg} / \mathrm{dl}$ ) for cows fed a pasture-only diet. During the final phase of the study plasma glucose concentrations for both dietary treatments were similar (Kolver and Muller, 1998). Plasma glucose concentrations of cows consuming pasture plus concentrate, pasture plus TMR, and TMR did not differ and averaged $65 \mathrm{mg} / \mathrm{dl}$ (Bargo et al., 2002a). Although initial (week 1) plasma NEFA concentrations were greatest for cows consuming pasture plus concentrate (302 meq/L), final (week 21) plasma NEFA concentrations were similar among dietary treatments and averaged $115 \mathrm{meq} / \mathrm{L}$ (Bargo et al., 2002a). A 37-wk study by Fontaneli et al. (2005) reported that plasma NEFA concentrations gradually decreased from calving to approximately 105 DIM, at which time NEFA concentrations remained unchanged. Also, plasma NEFA concentrations were greater during the first 28 DIM for cows that had access to pasture compared to cows consuming a TMR. The greater NEFA concentrations in cows consuming a pasture-based diet were attributed to greater BW losses while maintaining similar milk production compared to cows consuming the TMR.

\section{CONCLUSIONS}

Although the TMR feeding system evaluated in this study maximized total DMI and milk production, $4 \% \mathrm{FCM}$, milk fat and protein yields during the fall trial did not differ among dietary treatments. Fat-corrected milk yield in the spring study was greatest for treatments $85 \mathrm{~T}$ and $100 \mathrm{~T}$, and lowest for treatment $70 \mathrm{~T}$, with $55 \mathrm{~T}$ yielding intermediate. 
Milk fat and protein yields were greatest for treatments $85 \mathrm{~T}$ and 100T compared to those dietary treatments that had greater DMI from pasture. Greatest DMI from pasture was associated with the greatest concentration of CLA in milk. Concentrations of saturated fatty acids in milk fat were greatest for cows consuming TMR, and decreased with increasing amounts of pasture DMI. Restricting TMR intake lowered total DMI. Gross feed efficiencies (daily FCM yield per kg DMI) were similar for all dietary treatments during the fall, but cows consuming partial mixed rations exhibited enhanced gross feed efficiencies during the spring, compared to cows consuming TMR exclusively. Actual diets during the fall trial became $59 \%$ TMR and $41 \%$ pasture, $68 \%$ TMR and 32\% pasture, and $79 \%$ TMR and $21 \%$ pasture instead of the formulated 55T, 70T, and 85T, respectively. The corresponding actual diets during the spring trial turned out to be $65 \%$ TMR and 35\% pasture, $79 \%$ TMR and $21 \%$ pasture, and $89 \%$ TMR and $11 \%$, respectively. These studies suggest that TMR can be replaced with high-quality pasture up to the greatest amount of pasture DMI tested and that in PMR feeding systems such as the ones tested in this study pasture can be as high as $41 \%$ without affecting overall lactation performance when compared to an all-TMR ration. 


\section{LITERATURE CITED}

AFRC. 1993. Energy and protein requirements of ruminants. Agricultural and Food Research Council. CAB International, Wallingford, UK.

Aii T., S. Takahashi, M. Kurihara, and S. Kume (1988) The effects of Italian ryegrass hay, haylage and fresh Italian ryegrass on the fatty acid composition of cows' milk. Japanese J. Zootech. Sci.59:718-724.

Association of Official Analytical Chemists. 1990. Official Methods of Analysis. 15 ${ }^{\text {th }}$ Ed. AOAC, Arlington, VA.

Barrett, P. D., A. S. Laidlaw, C. S. Mayne, and H. Christie. 2001. Pattern of herbage intake rate and bite dimensions of rotationally grazed dairy cows as sward height declines. Grass and Forage Sci. 56:362-373.

Bargo, F., L. D. Muller, J. E. Delahoy, and T. W. Cassidy. 2002a. Performance of high producing dairy cows with three different feeding systems combining pasture and total mixed rations. J. Dairy Sci. 85:2948-2963.

Bargo, F., L. D. Muller, G. A. Varga, J. E. Delahoy, and T. W. Cassidy. 2002b. Ruminal digestion and fermentation of high-producing dairy cows with three different feeding systems combining pasture and total mixed rations. J. Dairy Sci. 85:2964-2973.

Bargo, F., L. D. Muller, E. S. Kolver, and J. E. Delahoy. 2003. Invited review: production and digestion of supplemented dairy cows on pasture. J. Dairy Sci. 86:1-42.

Baker, R. D. 2004. Estimating herbage intake from animal performance. Pages 95-120 in Herbage Intake Handbook, $2^{\text {nd }}$ Edition (Ed. P. D. Penning). The British Grassland Society. Baker, L. D., J. D. Ferguson, and W. Chalupa. 1995. Responses in urea and true protein of milk to different protein feeding schemes for dairy cows. J. Dairy Sci. 78:2424-2434. 
Bauman, D. E., and J. M. Griinari. 2001. Regulation and nutritional manipulation of milk fat: low-fat milk syndrome. Livestock Prod. Sci. 70:15-29.

Burns, J. C., K. R. Pond, and D. S. Fisher. 1994. Measurement of forage intake. Page 494 in Forage Quality, Evaluation, and Utilization (Eds. G. C. Fahey, M. Collins, D. R. Mertens, and L. E. Moser). ASA, CSSA, SSSA, Madison, WI.

Buxton, D. R., and D. R. Mertens. 1995. Quality-related characteristics of forages. Pages 8396 in Forages Volume II: The Science of Grassland Agriculture (Eds. R. F. Barnes, D. A. Miller, and C. J. Nelson) $5^{\text {th }}$ Edition. Iowa State University Press, Ames, IA.

Cammell, S. B., D. E. Beever, D. J. Thomson, A. R. Austin, H. R. Losada, R. T. Evans, M. C. Spooner, and R. A. Terry. 1983. Energy and protein digestion, supply and utilization on two contrasting forages fed to growing steers. Anim. Prod. 36:501.

Corbett, J. L., and F. S. Pickering. 1983. Rumen microbial degradation and synthesis of protein in grazing sheep. Page 301 in Feed Information and Animal Production (Eds. G. E. Robards R. G. Packham). Farnham Royal, UK.

Curran, M. K., and W. Holmes. 1970. Prediction of voluntary intake of food by dairy cows 2 . Lactating grazing cows. Anim. Prod. 12:213-224.

Dewhurst, R. J., W. J. Fisher, J. K. S. Tweed, and R. J. Wilkins. 2003. Comparison of grass and legume silages for milk production. 1. Production responses with different levels of concentrate. J. Dairy Sci. 86:2598-2611.

Dewhurst, R. J., N. D. Scollan, S. J. Youell, J. K. S. Tweed, and M. O. Humphreys. 2001. Influence of species, cutting date and cutting interval on the fatty acid composition of grasses. Grass and Forage Sci. 56:68-74.

Dewhurst R. J.., K. J. Shingfield, M. R. F. Lee, and N. D. Scollan. 2006. Increasing the 
concentrations of beneficial polyunsaturated fatty acids in milk produced by dairy cows in high forage systems. Anim. Feed Sci. Tech. Article in Press.

Dhiman, T. R., G. R. Anand, L. D. Satter, and M. W. Pariza. 1999. Conjugated linoleic acid content of milk from cows fed different diets. J. Dairy Sci. 82:2146-2156.

Elgersma, A., G. Ellen, H. van der Horst, H. Boer, P. R. Dekker, and S. Tamminga. 2004. Quick changes in milk fat composition from cows after transition from a fresh grass to a silage diet. Anim. Feed Sci. Tech. 117:13-27.

Elizalde, J. C., N. R. Merchen, and D. B. Faulkner. 1999. Fractionation of fiber and crude protein in fresh forages during the spring growth. J. Anim. Sci. 77:476-484.

Ellis, W. C., and H. Lippke. 1976. Nutritional values of forages. Pages 26-66 in Grasses and Legumes in Texas: Development, Production, and Utilization (Ed. E. C. Holt). RM-6C, Texas Agric. Exp. Stn.

Feussner, I., and C. Wasternack. 2002. The lipoxygenase pathway. Annu. Rev. Plant Biol. $53: 275-297$.

Fick, G. W., and D. W. Onstad. 1988. Statistical models for predicting alfalfa herbage quality from morphological or weather data. J. Prod. Agric. 1:160-166.

Fisher, D. S. 1994. Intake measurements with grazing animals. In: Research Techniques and Numerical Methods in Grassland and Forage Science. USDA-ARS, North Carolina State University. Available at: http://www.cropsci.ncsu.edu/dsfisher/index.html

Fisher, D. S., J. C. Burns, and K. R. Pond. 1988. Estimation of mean and median particle size of ruminant digesta. J. Dairy Sci. 71:518-524.

Fisher, D. S., H. F. Mayland, and J. C. Burns. 1999. Variation in ruminant preference for tall fescue hays cut either at sundown or at sunup. J. Anim. Sci. 77:762-768. 
Fisher, D. S., H. F. Mayland, and J. C. Burns. 2002. Variation in ruminant preference for alfalfa hays cut at sunup and sundown. Crop Sci. 42:231-237.

Fontaneli, R. S., L. E. Sollenberger, R. C. Littell, and C. R. Staples. 2005. Performance of lactating dairy cows managed on pasture-based or in freestall barn-feeding systems. J. Dairy Sci. 88:1264-1276.

Griggs, T. C., J. W. MacAdam, H. F. Mayland, and J. C. Burns. 2005. Nonstructural carbohydrate and digestibility patterns in orchardgrass swards during daily defoliation sequences initiated in evening and morning. Crop Sci. 45:1295-1304.

Hoffman, K. L., L. D. Muller, S. L. Fales, and L. A. Holden. 1993. Quality evaluation and concentrate supplementation of rotational pasture grazed by lactating cows. J. Dairy Sci. $76: 2651-2663$.

Holden, L. A., L. D. Muller, T. Lykos, and T. W. Cassidy. 1995. Effect of corn silage supplementation on intake and milk production in cows grazing grass pasture. J. Dairy Sci. 78:154-160.

Holden, L. A., L. D. Muller, G. A. Varga, and P. J. Hillard. 1994. Ruminal digestion and duodenal nutrient flows in dairy cows consuming grass as pasture, hay, or silage. J. Dairy Sci. 77:3034-3042.

Hughes, A. D. 1970. The non-protein nitrogen composition of grass silage II. The changes occurring during the storage of silage. J. Agric. Sci. (Camb.) 75:421-431.

Jahreis, G., J. Fritsche, and H. Steinhart. 1997. Conjugated linoleic acid in milk fat: high variation depending on production system. Nutr. Res. 17:1479-1484.

Jonker, J. S., R. A. Kohn, and R. A. Erdman. 1998. Using milk urea nitrogen to predict nitrogen excretion and utilization efficiency in lactating dairy cows. J. Dairy Sci. 81:2681- 
2692.

Jonker, J. S., R. A. Kohn, and J. High. 2002. Dairy herd management practices that impact nitrogen utilization efficiency. J. Dairy Sci. 85:1218-1226.

Kelly, M. L., E. S. Kolver, D. E. Bauman, M. E. Van Amburgh, and L. D. Muller. 1998. Effect of intake of pasture on concentrations of conjugated linoleic acid in milk of lactating dairy cows. J. Dairy Sci. 81:1630-1636.

Kepler, C. R., and S. B. Tove. 1967. Biohydrogenation of unsaturated fatty acids. J. Biol. Chem. 242:5686-5692.

Kim, E. J., R. Sanderson, M. S. Dhanoa, and R. J. Dewhurst. 2005. Fatty acid profiles associated with microbial colonization of freshly ingested grass and rumen biohydrogenation. J. Dairy Sci. 88:3220-3230.

Kolver, E. S., and L. D. Muller. 1998. Performance and nutrient intake of high producing Holstein cows consuming pasture or a total mixed ration. J. Dairy Sci. 81:1403-1411.

Kramer, J. K. G., V. Fellner, M. E. R. Dugan, F. D. Sauer, M. M. Mossoba, and M. P. Yurawecz. 1997. Evaluating acid and base catalysts in the methylation of milk and rumen fatty acids with special emphasis on conjugated dienes and total trans fatty acids. Lipids 32:1219-1228.

Lantinga, E. A., J. H. Neuteboom, and J. A. C. Meijs. 2004. Sward methods. Pages 23-52 in Herbage Intake Handbook, $2^{\text {nd }}$ Edition (Ed. P. D. Penning). Br. Grassl. Soc. Reading, UK. Licitra, G., T. M. Hernandez, and P. J. Van Soest. 1996. Standardization of procedures for nitrogen fractionation of ruminant feeds. Anim. Feed Sci. Tech. 57:347-358.

Loor, J. J., F. D. Soriano, X. Lin, J. H. Herbein, and C. E. Polan. 2003. Grazing allowance after the morning or afternoon milking for lactating dairy cows fed a total mixed ration 
(TMR) enhances trans 11-18:1 and cis 9, trans 11-18:2 (rumenic acid) in milk fat to different extents. Anim. Feed Sci. Tech. 109:105-119.

Lyttleton, J. W. 1973. Proteins and nucleic acids. Pages 63-103 in Chemistry and Biochemistry of Herbage. Volume 1 (Eds. G. W. Butler and R. W. Bailey). Academic Press, London, UK.

Macoon, B., L. E. Sollenberger, J. E. Moore, C. R. Staples, J. H. Fike, and K. M. Portier. 2003. Comparison of three techniques for estimating the forage intake of lactating dairy cows on pasture. J. Anim. Sci. 81:2357-2366.

McDonald, P. 1982. The effect of conservation processes on the nitrogenous components of forages. Pages 41-49 in Forage Protein in Ruminant Animal Production (Ed. D. J. Thompson, D. E. Beever, and R. G. Gunn). Occ. Publ. No. 6, Br. Soc. Anim. Sci.

Meijs, J. A. C., R. J. K. Walters, and A. Keen. 1982. Sward methods. Page 11 in Herbage Intake Handbook (Ed. J. D. Leaver). Br. Grassl. Soc., Hurley, UK.

Ministry of Agriculture, Fisheries and Food. 1975. Energy allowances and feeding systems for ruminants. Tech. Bull. 33. London, UK.

Minson, D. J. 1990. Protein in ruminant nutrition. Pages 162-207 in Forage in Ruminant Nutrition (Ed. T. J. Cunha). Academic Press, San Diego, CA.

Moore, D. A., and G. Varga. 1996. BUN and MUN: Urea nitrogen testing in dairy cattle. Comp. Cont. Edu. Pract. Vet. 18:712-721.

Muller, L. D., and S. L. Fales. 1998. Cool-season grass pastures for dairy cattle. Pages 335350 in Grass for Dairy Cattle (Eds. J. H. Cherney and D. J. R. Cherney). CAB International, New York, NY.

National Research Council. 1989. Nutrient Requirements of Dairy Cattle. $6^{\text {th }}$ Revised 
Edition. National Academies Press, Washington, DC.

National Research Council. 2001. Nutrient Requirements of Dairy Cattle. $7^{\text {th }}$ Revised Edition. National Academies Press, Washington, DC.

Nousiainen, J., K. J. Shingfield, and P. Huhtanen. 2004. Evaluation of milk urea nitrogen as a diagnostic of protein feeding. J. Dairy Sci. 87:386-398.

Orr, R. J., S. M. Rutter, P. D. Penning, and A. J. Rook. 2001. Matching grass supply to grazing patterns for dairy cows. Grass Forage Sci. 56:352-361.

Palmquist, D. L. 2001. Ruminal and endogenous synthesis of CLA in cows. Australian J. Dairy Tech. 56:134-137.

Parker, W. J., L. D. Muller, and D. R. Buckmaster. 1992. Management and economic implications of intensive grazing on dairy farms in the northeastern states. J. Dairy Sci. 75:2587-2597.

Peterson, D. G., J. A. Kelsey, and D. E. Bauman. 2002. Analysis of variation in cis-9, trans11 conjugated linoleic acid (CLA) in milk fat of dairy cows. J. Dairy Sci. 85:2164-2172.

Redfearn, D. D., B. C. Venuto, W. D. Pitman, M. W. Alison, and J. D. Ward. 2002. Cultivar and environmental effects on annual ryegrass forage yield, yield distribution, and nutritive value. Crop Sci. 42:2049-2054.

Reeves, M., W. J. Fulkerson, R. C. Kellaway, and H. Dove. 1996. A comparison of three techniques to determine the herbage intake of dairy cows grazing kikuyu (Pennisetum clandestinum) pasture. Aust. J. Exp. Agric. 36(1):23-30.

Reis, R. B., and D. K. Combs. 2000. Effects of increasing levels of grain supplementation on rumen environment and lactation performance of dairy cows grazing grass-legume pasture. J. Dairy Sci. 83:2888-2898. 
Rochinotti, D. 1998. Model components of forage-fed cattle systems: energy expenditure of grazing cattle and prediction of intake in dairy cows. Ph. D. Diss., University of Florida, Gainesville.

Roseler, D. K., J. D. Ferguson, C. J. Sniffen, and J. Herrema. 1993. Dietary protein degradability effects on plasma and milk urea nitrogen and milk nonprotein nitrogen in Holstein cows. J. Dairy Sci. 76:525-534.

Sanderson, M. A., and W. F. Wedin. 1989. Nitrogen concentrations in the cell wall and lignocellulose of smooth bromegrass herbage. Grass Forage Sci. 44:151-158.

SAS User's Guide: Statistics, Version 9.1.3 Edition. 2002. SAS Inst., Inc. Cary, NC.

Schroeder, G. F., J. J. Couderc, F. Bargo, and D. H. Rearte. 2005. Milk production and fatty acid profile of milk fat by dairy cows fed a winter oats (Avena sativa L.) pasture only or a total mixed ration. New Zealand J. Agric. Res. 48:187-195.

Schroeder, G. F., J. E. Delahoy, I. Vidaurreta, F. Bargo, G. A. Gagliostro, and L. D. Muller. 2003. Milk fatty acid composition of cows fed a total mixed ration or pasture plus concentrates replacing corn with fat. J. Dairy Sci. 86:3237-3248.

Schroeder, G. F., G. A. Gagliostro, F. Bargo, J. E. Delahoy, and L. D. Muller. 2004. Effects of fat supplementation on milk production and composition by dairy cows on pasture: a review. Livestock Prod. Sci. 86:1-18.

Smart, A. J., W. H. Schacht, J. D. Volesky, and L. E. Moser. 2006. Seasonal changes in dry matter partitioning, yield, and crude protein of intermediate wheatgrass and smooth bromegrass. Agron. J. 98:989-991.

Smit, H. J., H. Z. Taweel, B. M. Tas, S. Tamminga, and A. Elgersma. 2005. Comparison of techniques for estimating herbage intake of grazing dairy cows. J. Dairy Sci. 88:1827-1836. 
Soriano, F. D., C. E. Polan, and C. N. Miller. 2001. Supplementing pasture to lactating Holsteins fed a total mixed ration. J. Dairy Sci. 84:2460-2468.

Tamminga, S. 1986. Utilization of naturally occurring NPN-compounds by ruminants. Arch. Anim. Nutr. 36:169-176.

Tilley, J. M., and R. A. Terry. 1963. A two-stage technique for in vitro digestion of forage crops. J. Br. Grassl. Soc. 18:104-111.

Tucker, W. B., B. J. Rude, and S. Wittayakun. 2001. Case Study: Performance and economics of dairy cows fed a corn silage-based total mixed ration or grazing annual ryegrass during mid to late lactation. Prof. Anim. Sci. 17:195-201.

Undersander, D., D. R. Mertens, and N. Thiex. 1993. Forage Analyses Procedures. National Forage Testing Association. P. O. Box 371115, Omaha, NE 68137.

Van Soest, P. J. 1994. Nutritional Ecology of the Ruminant, $2^{\text {nd }}$ Edition. Cornell University Press, Ithaca, NY.

Van Soest, P. J., J. B. Robertson, and B. A. Lewis. 1991. Methods of dietary fiber, neutral detergent fiber, and nonstarch polysaccharides in relation to animal nutrition. J. Dairy Sci. 74:3583-3597.

Van Vuuren, A. M., S. Tamminga, and R. S. Ketelaar. 1991. In sacco degradation of organic matter and crude protein of fresh grass (Lolium perenne) in the rumen of grazing dairy cows. J. Agric. Sci. (Camb.) 116:429-436.

Vartha, E. W., and A. G. Matches. 1977. Use of a weighted-disk measure as an aid in sampling the herbage yield on tall fescue pastures grazed by cattle. Agron. J. 69:888-890.

Vasquez, O. P., and T. R. Smith. 2000. Factors affecting pasture intake and total dry matter intake in grazing dairy cows. J. Dairy Sci. 83:2301-2309. 
Washburn, S. P., S. L. White, J. T. Green, Jr., and G. A. Benson. 2002. Reproduction, mastitis, and body condition of seasonally calved Holstein and Jersey cows in confinement or pasture systems. J. Dairy Sci. 85:105-111.

White, S. L., G. A. Benson, S. P. Washburn, and J. T. Green, Jr. 2002. Milk production and economic measures in confinement or pasture systems using seasonally calved Holstein and Jersey cows. J. Dairy Sci. 85:95-104.

White, S. L., J. A. Bertrand, M. R. Wade, S. P. Washburn, J. T. Green, Jr., and T. C. Jenkins. 2001a. Comparison of fatty acid content of milk from Jersey and Holstein cows consuming pasture or a total mixed ration. J. Dairy Sci. 84:2295-2301.

White, S. L., R. E. Sheffield, S. P. Washburn, L. D. King, and J. T. Green, Jr. 2001b. Spatial and time distribution of dairy cattle excreta in an intensive pasture system. J. Environ. Qual. 30:2180-2187.

Wildman, E. E., G. M. Jones, P. E. Wagner, R. L. Boman, H. F. Troutt, and T. N. Lesch. 1982. A dairy cow body condition scoring system and its relationship to selected production characteristics. J. Dairy Sci. 65:495-501.

Wilman, D., and P. T. Wright. 1983. Some aspects of applied nitrogen on the growth and chemical composition of temperate grasses. Herbage Abstracts 53:387-393.

Wittwer, F. G., P. Gallardo, J. Reyes, and H. Opitz. 1999. Bulk milk urea concentrations and their relationship with cow fertility in grazing dairy herds in Southern Chile. Prev. Vet. Med. $38: 159-166$.

Wu, Z., V. R. Kanneganti, J. Massingill, M. C. Wiltbank, R. P. Walgenbach, and L. D. Satter. 2001. Milk production of fall-calving dairy cows during summer grazing of grass or grass-clover pasture. J. Dairy Sci. 84:1166-1173. 
Table 1. Ranges, means, standard errors of calibration (SEC), standard errors of cross-validation (SECV), and associated coefficients of determination $\left(R^{2}\right)$ for various constituents of annual ryegrass predicted by near-infrared reflectance spectroscopy.

\begin{tabular}{|c|c|c|c|c|c|c|c|}
\hline \multirow[b]{2}{*}{ Item } & \multirow{2}{*}{$\mathbf{n}$} & \multirow{2}{*}{$\begin{array}{c}\text { Range } \\
\text { g/kg }\end{array}$} & \multirow{2}{*}{$\begin{array}{c}\text { Mean } \\
\mathrm{g} / \mathrm{kg}\end{array}$} & \multicolumn{2}{|c|}{ Calibration } & \multicolumn{2}{|c|}{ Validation } \\
\hline & & & & SEC, g/kg & $\mathbf{R}^{2}$ & $\overline{\mathrm{SECV}, \mathrm{g} / \mathrm{kg}}$ & $\mathbf{R}^{2}$ \\
\hline DM & 92 & 939-983 & 963 & 3.9 & 0.869 & 5.2 & 0.760 \\
\hline $\mathrm{OM}$ & 92 & $807-948$ & 899 & 3.3 & 0.992 & 4.9 & 0.983 \\
\hline NDF & 93 & $389-541$ & 458 & 6.9 & 0.954 & 10.4 & 0.894 \\
\hline NDF corr ${ }^{1}$ & 92 & $386-538$ & 448 & 5.2 & 0.975 & 11.2 & 0.886 \\
\hline ADF & 88 & $176-289$ & 230 & 3.6 & 0.974 & 5.4 & 0.943 \\
\hline ADF corr ${ }^{1}$ & 89 & $181-285$ & 219 & 5.0 & 0.957 & 5.9 & 0.940 \\
\hline CP, \%DM & 91 & $41-319$ & 142 & 2.3 & 0.999 & 3.5 & 0.997 \\
\hline $\mathrm{CP}, \% \mathrm{OM}$ & 89 & $42-315$ & 152 & 2.6 & 0.999 & 3.8 & 0.998 \\
\hline IVTDMD $^{2}$ & 91 & $775-971$ & 897 & 3.9 & 0.992 & 6.2 & 0.981 \\
\hline IVTOMD $^{3}$ & 92 & $782-973$ & 910 & 6.0 & 0.983 & 7.5 & 0.974 \\
\hline
\end{tabular}

${ }^{1}$ Corrected for ash.

${ }^{2}$ In vitro true DM disappearance.

${ }^{3}$ In vitro true OM disappearance. 
Table 2. Ingredient and chemical composition (mean $\pm \mathrm{SE}$ ) of the total mixed ration (TMR) offered to all cows during Experiment 1 (F2004) and 2 (S2005).

\begin{tabular}{|c|c|c|}
\hline Ingredient composition $^{1}$ & \multicolumn{2}{|c|}{ DM, \% } \\
\hline Corn silage & \multicolumn{2}{|c|}{26.9} \\
\hline Alfalfa silage & \multicolumn{2}{|c|}{13.0} \\
\hline Whole cottonseed & \multicolumn{2}{|c|}{18.0} \\
\hline Soybean hulls & \multicolumn{2}{|c|}{9.1} \\
\hline Corn gluten feed & \multicolumn{2}{|c|}{8.9} \\
\hline Bypass blend ${ }^{2}$ & \multicolumn{2}{|c|}{4.4} \\
\hline Corn grain, ground & \multicolumn{2}{|c|}{15.9} \\
\hline $48 \% \mathrm{SBM}^{3}$ & \multicolumn{2}{|c|}{1.2} \\
\hline Calcitic limestone & \multicolumn{2}{|c|}{0.55} \\
\hline Salt & \multicolumn{2}{|c|}{0.43} \\
\hline Sodium bicarbonate & \multicolumn{2}{|c|}{0.75} \\
\hline Bentonite $^{4}$ & \multicolumn{2}{|c|}{0.65} \\
\hline Vitamin TM premix & \multicolumn{2}{|c|}{0.12} \\
\hline Potassium carbonate & \multicolumn{2}{|c|}{0.02} \\
\hline Chemical composition & F2004 & $\mathbf{S 2 0 0 5}$ \\
\hline $\mathrm{DM}, \%$ & $52.5 \pm 0.7$ & $50.8 \pm 0.6$ \\
\hline $\mathrm{OM}, \%$ of $\mathrm{DM}$ & $92.9 \pm 0.2$ & $93.2 \pm 0.2$ \\
\hline NDF, $\%$ of DM & $43.0 \pm 0.7$ & $44.3 \pm 0.6$ \\
\hline $\mathrm{ADF}, \%$ of $\mathrm{DM}$ & $21.5 \pm 0.9$ & $22.2 \pm 0.8$ \\
\hline $\mathrm{CP}, \%$ of $\mathrm{DM}$ & $15.8 \pm 0.4$ & $15.9 \pm 0.3$ \\
\hline \multicolumn{3}{|l|}{ Protein fractions, $\%$ of $\mathrm{CP}$} \\
\hline$A^{5}$ & 26.9 & 26.4 \\
\hline $\mathrm{B}_{1}{ }^{6}$ & 4.4 & 3.0 \\
\hline $\mathrm{B}_{2}{ }^{7}$ & 62.9 & 65.0 \\
\hline $\mathrm{B}_{3}{ }^{8}$ & 3.2 & 2.9 \\
\hline $\mathrm{C}^{9}$ & 2.6 & 2.7 \\
\hline RUP, $\%$ of $\mathrm{DM}^{10}$ & 6.9 & 6.9 \\
\hline IVTDMD, $\%$ of $\mathrm{DM}^{11}$ & $83.0 \pm 1.1$ & $79.6 \pm 1.5$ \\
\hline $\mathrm{NE}_{1}, \mathrm{Mcal} / \mathrm{kg} \mathrm{DM}^{10}$ & 1.60 & 1.60 \\
\hline \multicolumn{3}{|c|}{$\begin{array}{l}{ }^{1} \text { Mineral composition, DM basis: } 0.77 \% \mathrm{Ca} ; 0.45 \% \mathrm{P} ; 0.24 \% \mathrm{Mg} ; 1.09 \% \mathrm{~K} ; 0.24 \% \mathrm{~S} \text {; } \\
0.38 \% \mathrm{Na} ; 19 \mathrm{ppm} \mathrm{Cu} ; 374 \text { ppm Fe; } 67 \mathrm{ppm} \mathrm{Mn;} 87 \text { ppm Zn. }\end{array}$} \\
\hline \multicolumn{3}{|c|}{$\begin{array}{l}{ }^{2} \text { Blend of poultry by-product meal, hydrolyzed poultry feathers, meat and bone meal, } \\
\text { blood meal, and fish meal (Nutrimax Inc., Greensboro, NC). }{ }^{3} \text { Soybean meal. } \\
{ }^{4} \text { Volclay }{ }^{\circledR} \text { (American colloid Co., Arlington Heights, IL). }\end{array}$} \\
\hline
\end{tabular}


Table 3. Nutritive value of hand-plucked weekly composites of annual ryegrass samples, Experiment 1, F2004.

\begin{tabular}{|c|c|c|c|c|c|c|c|c|c|}
\hline \multirow[b]{3}{*}{ Item } & \multicolumn{8}{|c|}{ week } & \multirow[b]{3}{*}{ SE } \\
\hline & 1 & 2 & 3 & 4 & 5 & 6 & 7 & 8 & \\
\hline & \multicolumn{3}{|c|}{ Adaptation Period } & \multicolumn{5}{|c|}{ - Sampling Period } & \\
\hline DM, \% & 13.9 & 13.3 & 14.7 & 15.9 & 13.2 & 16.2 & 15.8 & 21.1 & 0.90 \\
\hline $\mathrm{OM}, \%$ of DM & 86.7 & 86.5 & 86.9 & 88.5 & 87.5 & 88.4 & 88.2 & 89.9 & 0.41 \\
\hline NDF, $\%$ of DM & 46.3 & 48.8 & 44.5 & 40.2 & 42.3 & 44.4 & 42.6 & 38.6 & 1.16 \\
\hline $\mathrm{ADF}, \%$ of $\mathrm{DM}$ & 23.5 & 23.3 & 21.0 & 19.4 & 21.2 & 22.0 & 22.0 & 17.6 & 0.70 \\
\hline $\mathrm{CP}, \%$ of DM & 31.9 & 28.6 & 26.0 & 22.8 & 25.8 & 24.5 & 23.8 & 21.6 & 1.17 \\
\hline \multicolumn{10}{|c|}{ Protein fractions, $\%$ of $\mathrm{CP}$} \\
\hline $\mathrm{A}^{1}$ & 20.8 & 15.6 & 15.4 & 16.2 & 17.2 & 25.7 & 21.8 & 15.5 & 1.35 \\
\hline $\mathrm{B}_{1}{ }^{2}$ & 35.2 & 33.7 & 31.8 & 29.0 & 27.0 & 30.1 & 32.9 & 32.4 & 0.94 \\
\hline $\mathrm{B}_{2}{ }^{3}$ & 37.3 & 42.5 & 44.3 & 45.6 & 48.0 & 37.8 & 37.6 & 43.1 & 1.43 \\
\hline $\mathrm{B}_{3}{ }^{4}$ & 2.6 & 4.2 & 4.8 & 6.9 & 4.1 & 3.7 & 4.4 & 6.0 & 0.47 \\
\hline $\mathrm{C}^{5}$ & 4.1 & 4.1 & 3.8 & 2.2 & 3.7 & 2.8 & 3.3 & 3.0 & 0.24 \\
\hline IVTOMD, $\%^{6}$ & 96.7 & 96.6 & 96.7 & 96.1 & 94.8 & 96.4 & 97.1 & 97.2 & 0.27 \\
\hline \multicolumn{10}{|c|}{ Minerals, $\%$ of DM } \\
\hline $\mathrm{Ca}, \% \mathrm{DM}$ & 0.43 & & & & 0.44 & & & 0.46 & 0.01 \\
\hline $\mathrm{P}, \% \mathrm{DM}$ & 0.52 & & & & 0.50 & & & 0.40 & 0.04 \\
\hline $\mathrm{Mg}, \% \mathrm{DM}$ & 0.28 & & & & 0.32 & & & 0.24 & 0.02 \\
\hline $\mathrm{K}, \% \mathrm{DM}$ & 4.21 & & & & 4.96 & & & 3.58 & 0.40 \\
\hline $\mathrm{Na}, \% \mathrm{DM}$ & 0.03 & & & & 0.06 & & & 0.05 & 0.01 \\
\hline $\mathrm{S}, \% \mathrm{DM}$ & 0.34 & & & & 0.34 & & & 0.30 & 0.01 \\
\hline
\end{tabular}

${ }^{1}$ Non-protein N.

${ }^{2}$ Borate buffer soluble $\mathrm{N}$

${ }^{3}$ Insoluble protein - NDIP.

${ }^{4}$ NDIP - ADIP.

${ }^{5} \mathrm{ADIP}$.

${ }^{6}$ In vitro true OM disappearance. 
Table 4. Nutritive value of hand-plucked weekly composites of annual ryegrass samples, Experiment 2, S2005.

\begin{tabular}{|c|c|c|c|c|c|c|c|c|c|}
\hline \multirow[b]{3}{*}{ Item } & \multicolumn{8}{|c|}{ week } & \multirow[b]{3}{*}{ SE } \\
\hline & 1 & 2 & 3 & 4 & 5 & 6 & 7 & 8 & \\
\hline & \multicolumn{3}{|c|}{ Adaptation Period } & \multicolumn{5}{|c|}{ - Sampling Period -} & \\
\hline DM, \% & 16.5 & 18.6 & 19.3 & 21.3 & 25.9 & 25.7 & 25.6 & 25.7 & 1.36 \\
\hline $\mathrm{OM}, \%$ of $\mathrm{DM}$ & 90.0 & 90.5 & 91.8 & 92.3 & 92.9 & 93.2 & 93.1 & 92.9 & 0.43 \\
\hline NDF, $\%$ of DM & 47.7 & 45.8 & 44.0 & 41.9 & 44.8 & 44.2 & 46.2 & 46.6 & 0.64 \\
\hline $\mathrm{ADF}, \%$ of $\mathrm{DM}$ & 23.2 & 22.9 & 21.5 & $20.8-$ & 21.1 & 20.6 & 21.8 & 23.0 & 0.37 \\
\hline $\mathrm{CP}, \%$ of $\mathrm{DM}$ & 21.8 & 18.3 & 17.9 & 15.1 & 13.8 & 11.8 & 14.2 & 14.6 & 1.13 \\
\hline \multicolumn{10}{|c|}{ Protein fractions, $\%$ of $\mathrm{CP}$} \\
\hline $\mathrm{A}^{1}$ & 13.6 & 12.5 & 10.9 & 9.6 & 9.6 & 12.2 & 13.4 & 13.2 & 0.58 \\
\hline $\mathrm{B}_{1}{ }^{2}$ & 35.0 & 32.9 & 36.4 & 36.0 & 40.2 & 38.4 & 35.8 & 33.2 & 0.87 \\
\hline $\mathrm{B}_{2}^{3}$ & 45.9 & 48.2 & 46.0 & 47.2 & 44.3 & 44.0 & 46.0 & 48.1 & 0.55 \\
\hline $\mathrm{B}_{3}{ }^{4}$ & 3.1 & 4.2 & 3.8 & 6.0 & 4.8 & 4.4 & 3.8 & 4.6 & 0.30 \\
\hline $\mathrm{C}^{5}$ & 2.4 & 2.2 & 2.9 & 1.2 & 1.1 & 1.0 & 0.9 & 0.9 & 0.28 \\
\hline IVTOMD, $\%{ }^{6}$ & 93.6 & 94.9 & 94.7 & 94.8 & 93.2 & 93.5 & 93.3 & 91.6 & 0.39 \\
\hline \multicolumn{10}{|c|}{ Minerals, $\%$ of DM } \\
\hline $\mathrm{Ca}, \% \mathrm{DM}$ & 0.39 & & & & 0.50 & & & 0.32 & 0.05 \\
\hline $\mathrm{P}, \% \mathrm{DM}$ & 0.52 & & & & 0.32 & & & 0.38 & 0.06 \\
\hline $\mathrm{Mg}, \% \mathrm{DM}$ & 0.23 & & & & 0.20 & & & 0.17 & 0.02 \\
\hline $\mathrm{K}, \% \mathrm{DM}$ & 3.70 & & & & 2.89 & & & 2.52 & 0.35 \\
\hline $\mathrm{Na}, \% \mathrm{DM}$ & 0.02 & & & & 0.02 & & & 0.02 & 0.00 \\
\hline $\mathrm{S}, \% \mathrm{DM}$ & 0.28 & & & & 0.23 & & & 0.23 & 0.02 \\
\hline
\end{tabular}

${ }^{1}$ Non-protein N.

${ }^{2}$ Borate buffer soluble $\mathrm{N}$

${ }^{3}$ Insoluble protein - NDIP.

${ }^{4}$ NDIP - ADIP.

${ }^{5}$ ADIP.

${ }^{6}$ In vitro true OM disappearance. 
Table 5. Nutritive value of annual ryegrass herbage mass samples by week, Experiment 1, F2004.

\begin{tabular}{|c|c|c|c|c|c|c|c|}
\hline \multirow[b]{3}{*}{ Item } & \multicolumn{6}{|c|}{ week } & \multirow[b]{3}{*}{ SE } \\
\hline & 2 & 3 & 4 & 6 & 8 & 8 & \\
\hline & \multicolumn{6}{|c|}{ Pre-grazing herbage mass } & \\
\hline $\mathrm{DM}, \mathrm{g} / \mathrm{kg}$ & 132 & 146 & 162 & 161 & 182 & 205 & 10.6 \\
\hline $\mathrm{OM}, \mathrm{g} / \mathrm{kg} \mathrm{DM}$ & 781 & 842 & 862 & 874 & 857 & 848 & 13.4 \\
\hline $\mathrm{NDF}, \mathrm{g} / \mathrm{kg} \mathrm{DM}$ & 492 & 451 & 412 & 432 & 448 & 456 & 10.9 \\
\hline NDF corr ${ }^{1}$ & 425 & 443 & 399 & 432 & 437 & 433 & 6.3 \\
\hline $\mathrm{ADF}, \mathrm{g} / \mathrm{kg} \mathrm{DM}$ & 296 & 244 & 214 & 226 & 225 & 229 & 12.1 \\
\hline ADF corr ${ }^{1}$ & 234 & 226 & 194 & 217 & 210 & 200 & 6.2 \\
\hline $\mathrm{CP}, \mathrm{g} / \mathrm{kg} \mathrm{DM}$ & 257 & 224 & 199 & 215 & 194 & 191 & 10.2 \\
\hline $\mathrm{CP}, \% \mathrm{OM}$ & 320 & 257 & 227 & 238 & 220 & 220 & 15.7 \\
\hline IVTDMD, g/ $\mathrm{kg}^{2}$ & 833 & 928 & 941 & 936 & 924 & 904 & 16.4 \\
\hline IVTOMD, $\mathrm{g} / \mathrm{kg}^{3}$ & 901 & 945 & 959 & 951 & 944 & 933 & 8.3 \\
\hline $\mathrm{NE}_{\mathrm{l}}, \mathrm{Mcal} / \mathrm{kg} \mathrm{DM}{ }^{4}$ & 1.41 & 1.58 & 1.68 & 1.64 & 1.65 & 1.63 & 0.0 \\
\hline Leaf, \% of DM & 52.6 & 55.8 & 59.7 & 57.3 & 47.9 & 44.7 & 2.4 \\
\hline Stem, $\%$ of DM & 15.1 & 18.4 & 26.3 & 32.5 & 28.0 & 38.2 & 3.5 \\
\hline \multirow[t]{2}{*}{ Leaf/stem ratio } & 3.48 & 3.03 & 2.27 & 1.76 & 1.71 & 1.17 & 0.4 \\
\hline & \multicolumn{6}{|c|}{ Post-grazing herbage mass } & \\
\hline $\mathrm{DM}, \mathrm{g} / \mathrm{kg}$ & 125 & 147 & 159 & 172 & 202 & 204 & 12.7 \\
\hline $\mathrm{OM}, \mathrm{g} / \mathrm{kg} \mathrm{DM}$ & 820 & 808 & 848 & 866 & 847 & 845 & 8.6 \\
\hline NDF, g/kg DM & 480 & 456 & 419 & 439 & 467 & 445 & 8.8 \\
\hline NDF corr ${ }^{1}$ & 450 & 408 & 394 & 434 & 448 & 428 & 9.1 \\
\hline $\mathrm{ADF}, \mathrm{g} / \mathrm{kg} \mathrm{DM}$ & 266 & 261 & 223 & 230 & 233 & 224 & 7.8 \\
\hline ADF corr $^{1}$ & 245 & 206 & 202 & 218 & 215 & 191 & 7.5 \\
\hline $\mathrm{CP}, \mathrm{g} / \mathrm{kg} \mathrm{DM}$ & 261 & 201 & 209 & 210 & 195 & 186 & 10.8 \\
\hline $\mathrm{CP}, \% \mathrm{OM}$ & 313 & 243 & 241 & 235 & 224 & 216 & 14.2 \\
\hline IVTDMD, g/ $\mathrm{kg}^{2}$ & 898 & 880 & 927 & 928 & 915 & 911 & 7.5 \\
\hline IVTOMD, $\mathrm{g} / \mathrm{kg}^{3}$ & 927 & 930 & 949 & 944 & 940 & 940 & 3.4 \\
\hline $\mathrm{NE}_{\mathrm{l}}, \mathrm{Mcal} / \mathrm{kg} \mathrm{DM}$ & 1.51 & 1.53 & 1.65 & 1.63 & 1.62 & 1.65 & 0.0 \\
\hline Leaf, $\%$ of DM & 56.8 & 55.7 & 54.8 & 51.3 & 33.9 & 38.8 & 4.0 \\
\hline Stem, $\%$ of DM & 20.9 & 22.7 & 21.8 & 35.0 & 38.2 & 36.2 & 3.3 \\
\hline Leaf/stem ratio & 2.72 & 2.45 & 2.51 & 1.47 & 0.89 & 1.07 & 0.3 \\
\hline
\end{tabular}

${ }^{1}$ Corrected for ash. ${ }^{2}$ In vitro true DM disappearance.

${ }^{3}$ In vitro true OM disappearance.

${ }^{4} \mathrm{NE}_{1}(\mathrm{Mcal} / \mathrm{kg} \mathrm{DM})=1.085-(0.015 * \% \mathrm{ADF}) * 2.2026$ 
Table 6. Nutritive value of annual ryegrass herbage mass samples by week, Experiment 2, S2005.

\begin{tabular}{|c|c|c|c|c|c|c|c|c|c|}
\hline \multirow[b]{3}{*}{ Item } & \multicolumn{8}{|c|}{ week } & \multirow[b]{3}{*}{ SE } \\
\hline & 1 & 2 & 3 & 4 & 5 & 6 & 7 & 8 & \\
\hline & \multicolumn{8}{|c|}{ Pre-grazing herbage mass } & \\
\hline $\mathrm{DM}, \mathrm{g} / \mathrm{kg}$ & 213 & 217 & 188 & 268 & 316 & 352 & 336 & 344 & 23.4 \\
\hline $\mathrm{OM}, \mathrm{g} / \mathrm{kg} \mathrm{DM}$ & 913 & 906 & 907 & 930 & 932 & 931 & 939 & 945 & 5.2 \\
\hline NDF, g/kg DM & 471 & 451 & 479 & 426 & 419 & 459 & 478 & 511 & 10.6 \\
\hline NDF corr ${ }^{1}$ & 471 & 452 & 473 & 420 & 412 & 453 & 477 & 509 & 11.2 \\
\hline $\mathrm{ADF}, \mathrm{g} / \mathrm{kg} \mathrm{DM}$ & 220 & 218 & 248 & 212 & 203 & 218 & 248 & 274 & 8.5 \\
\hline ADF corr ${ }^{1}$ & 201 & 206 & 240 & 205 & 187 & 211 & 243 & 264 & 9.3 \\
\hline $\mathrm{CP}, \mathrm{g} / \mathrm{kg} \mathrm{DM}$ & 140 & 119 & 114 & 79 & 69 & 82 & 63 & 53 & 10.9 \\
\hline $\mathrm{CP}, \% \mathrm{OM}$ & 145 & 126 & 120 & 80 & 73 & 83 & 65 & 54 & 11.6 \\
\hline IVTDMD, $\mathrm{g} / \mathrm{kg}^{2}$ & 892 & 904 & 895 & 905 & 900 & 876 & 838 & 799 & 13.5 \\
\hline IVTOMD, g/kg ${ }^{3}$ & 911 & 916 & 899 & 914 & 915 & 885 & 840 & 809 & 14.2 \\
\hline $\mathrm{NE}_{\mathrm{l}}, \mathrm{Mcal} / \mathrm{kg} \mathrm{DM}{ }^{4}$ & 1.66 & 1.67 & 1.57 & 1.69 & 1.72 & 1.67 & 1.57 & 1.48 & 0.0 \\
\hline Leaf, $\%$ of DM & 37.8 & 43.7 & 37.9 & 30.0 & 30.7 & 21.2 & 15.3 & 9.4 & 4.2 \\
\hline Stem, $\%$ of DM & 28.1 & 33.5 & 50.5 & 50.7 & 46.0 & 49.9 & 61.3 & 65.2 & 4.4 \\
\hline \multirow[t]{2}{*}{ Leaf/stem ratio } & 1.35 & 1.30 & 0.75 & 0.59 & 0.67 & 0.42 & 0.25 & 0.14 & 0.2 \\
\hline & \multicolumn{8}{|c|}{ Post-grazing herbage mass } & \\
\hline $\mathrm{DM}, \mathrm{g} / \mathrm{kg}$ & 183 & 210 & 205 & 286 & 315 & 355 & 363 & 384 & 28.0 \\
\hline $\mathrm{OM}, \mathrm{g} / \mathrm{kg} \mathrm{DM}$ & 900 & 899 & 907 & 927 & 936 & 940 & 943 & 949 & 7.2 \\
\hline $\mathrm{NDF}, \mathrm{g} / \mathrm{kg} \mathrm{DM}$ & 481 & 473 & 499 & 466 & 448 & 474 & 492 & 519 & 7.7 \\
\hline NDF corr ${ }^{1}$ & 467 & 461 & 494 & 461 & 442 & 464 & 486 & 512 & 7.9 \\
\hline $\mathrm{ADF}, \mathrm{g} / \mathrm{kg} \mathrm{DM}$ & 231 & 232 & 258 & 238 & 222 & 231 & 254 & 281 & 6.9 \\
\hline ADF corr ${ }^{1}$ & 211 & 210 & 250 & 229 & 216 & 225 & 256 & 274 & 8.3 \\
\hline $\mathrm{CP}, \mathrm{g} / \mathrm{kg} \mathrm{DM}$ & 130 & 108 & 100 & 69 & 60 & 72 & 55 & 43 & 10.6 \\
\hline $\mathrm{CP}, \% \mathrm{OM}$ & 139 & 114 & 104 & 71 & 61 & 72 & 55 & 44 & 11.6 \\
\hline IVTDMD, g/kg ${ }^{2}$ & 876 & 882 & 878 & 862 & 875 & 853 & 823 & 789 & 11.6 \\
\hline IVTOMD, $\mathrm{g} / \mathrm{kg}^{3}$ & 900 & 900 & 882 & 869 & 882 & 859 & 824 & 797 & 12.9 \\
\hline $\mathrm{NE}_{\mathrm{l}}, \mathrm{Mcal} / \mathrm{kg} \mathrm{DM}^{4}$ & 1.63 & 1.62 & 1.54 & 1.60 & 1.66 & 1.63 & 1.55 & 1.46 & 0.0 \\
\hline Leaf, $\%$ of DM & 31.4 & 32.2 & 26.7 & 12.7 & 12.7 & 17.1 & 10.7 & 5.0 & 3.6 \\
\hline Stem, $\%$ of DM & 31.2 & 38.0 & 54.9 & 56.7 & 57.8 & 57.2 & 65.1 & 65.7 & 4.4 \\
\hline Leaf/stem ratio & 1.01 & 0.85 & 0.49 & 0.22 & 0.22 & 0.30 & 0.16 & 0.08 & 0.1 \\
\hline
\end{tabular}

${ }^{1}$ Corrected for ash. ${ }^{2}$ In vitro true DM disappearance.

${ }^{3}$ In vitro true OM disappearance.

${ }^{4} \mathrm{NE}_{1}(\mathrm{Mcal} / \mathrm{kg} \mathrm{DM})=1.085-(0.015 * \% \mathrm{ADF}) * 2.2026$ 
Table 7. Dry matter, CP, NDF, and net energy intake of cows offered varying amounts of TMR and grazing pasture, Experiment 1, F2004.

\begin{tabular}{|c|c|c|c|c|c|c|}
\hline \multirow[b]{2}{*}{ Item } & \multicolumn{4}{|c|}{ Treatments $^{1}$} & \multirow[b]{2}{*}{ SEM } & \multirow{2}{*}{$\frac{P \leq^{2}}{t}$} \\
\hline & $55 \mathrm{~T}$ & $70 \mathrm{~T}$ & $85 \mathrm{~T}$ & 100T & & \\
\hline \multicolumn{7}{|l|}{ DM intake } \\
\hline TMR, kg/d & 12.5 & 14.5 & 17.3 & 25.8 & 0.5 & $\ldots$ \\
\hline Pasture, ${ }^{3} \mathrm{~kg} / \mathrm{d}$ & 8.7 & 6.8 & 4.5 & . & 2.0 & 0.12 \\
\hline Pasture, ${ }^{4} \mathrm{~kg} / \mathrm{d}$ & 7.9 & 6.7 & 5.7 & • & 0.9 & $\ldots$ \\
\hline Total, kg/d & $21.2^{\mathrm{a}}$ & $21.3^{\mathrm{a}}$ & $21.8^{\mathrm{a}}$ & $25.8^{\mathrm{b}}$ & 2.0 & 0.05 \\
\hline Total, \% BW & $3.80^{\mathrm{e}}$ & $3.77^{\mathrm{e}}$ & $3.83^{\mathrm{e}}$ & $4.57^{\mathrm{f}}$ & 0.25 & 0.10 \\
\hline \multicolumn{7}{|l|}{ CP intake } \\
\hline TMR, kg/d & 2.0 & 2.3 & 2.7 & 4.1 & 0.08 & $\ldots$ \\
\hline Pasture, $\mathrm{kg} / \mathrm{d}$ & 2.1 & 1.6 & 1.2 & . & 0.38 & 0.12 \\
\hline Total, $\mathrm{kg} / \mathrm{d}$ & 4.1 & 3.9 & 3.9 & 4.1 & 0.30 & 0.90 \\
\hline \multicolumn{7}{|l|}{ NDF intake } \\
\hline TMR, kg/d & 5.4 & 6.2 & 7.5 & 11.2 & 0.21 & $\ldots$ \\
\hline Pasture, $\mathrm{kg} / \mathrm{d}$ & 3.7 & 2.8 & 2.0 & . & 0.70 & 0.12 \\
\hline Total, kg/d & $9.1^{\mathrm{a}}$ & $9.0^{\mathrm{a}}$ & $9.5^{\mathrm{a}}$ & $11.2^{\mathrm{b}}$ & 0.60 & 0.05 \\
\hline \multicolumn{7}{|l|}{$\mathrm{NE}_{1}$ intake $^{5}$} \\
\hline TMR, Mcal/d & 20.0 & 23.1 & 27.7 & 41.9 & 0.8 & $\ldots$ \\
\hline Pasture, Mcal/d & 13.0 & 9.8 & 7.3 & . & 2.3 & 0.12 \\
\hline Total, Mcal/d & $33.0^{\mathrm{a}}$ & $32.9^{\mathrm{a}}$ & $35.0^{\mathrm{a}}$ & $41.9^{\mathrm{b}}$ & 2.3 & 0.04 \\
\hline \multicolumn{7}{|l|}{ Total $\operatorname{diet}^{6}$} \\
\hline $\mathrm{F}: \mathrm{C}^{7}$ & $64: 36^{\mathrm{a}}$ & $59: 41^{\mathrm{ab}}$ & $51: 49^{\mathrm{b}}$ & $40: 60^{\mathrm{c}}$ & 2.9 & 0.001 \\
\hline $\mathrm{GFE}^{8}$ & 1.54 & 1.43 & 1.46 & 1.27 & 0.16 & 0.37 \\
\hline
\end{tabular}

${ }^{1} 55 \mathrm{~T}=55 \% \mathrm{TMR}+$ pasture, $70 \mathrm{~T}=70 \% \mathrm{TMR}+$ pasture, $85 \mathrm{~T}=85 \% \mathrm{TMR}+$ pasture, $100 \mathrm{~T}=100 \% \mathrm{TMR}^{2} \mathrm{t}=$ treatment.

${ }^{3}$ Pasture consumed (based on pre- and post-grazing herbage mass).

${ }^{4}$ Pasture consumed (based on NRC, 2001).

${ }^{5} \mathrm{NE}_{1}$ for TMR and pasture were 1.60 and $1.45 \mathrm{Mcal} / \mathrm{kg} \mathrm{DM}$, respectively (NRC, 2001).

${ }^{6} \mathrm{DM}$ basis.

${ }^{7}$ Forage-to-concentrate ratio.

${ }^{8}$ Gross feed efficiency $=(\mathrm{FCM}$ yield, $\mathrm{kg} / \mathrm{d}) /(\mathrm{DMI}, \mathrm{kg} / \mathrm{d})$

${ }^{a, b, c}$ Least squares means in the same row with different superscripts $\operatorname{differ}(P \leq 0.05)$.

${ }^{\mathrm{e}, \mathrm{f}}$ Least squares means in the same row with different superscripts differ $(P \leq 0.10)$. 
Table 8. Dry matter, CP, NDF, and net energy intake of cows offered varying amounts of TMR and grazing pasture, Experiment 2, S2005.

\begin{tabular}{|c|c|c|c|c|c|c|}
\hline \multirow[b]{2}{*}{ Item } & \multicolumn{4}{|c|}{ Treatments $^{1}$} & \multirow[b]{2}{*}{ SEM } & \multirow{2}{*}{$\frac{P \leq^{2}}{t}$} \\
\hline & $55 \mathrm{~T}$ & $70 T$ & $85 T$ & $100 \mathrm{~T}$ & & \\
\hline \multicolumn{7}{|l|}{ DM intake } \\
\hline TMR, kg/d & 12.6 & 15.4 & 18.2 & 24.9 & 0.3 & $\ldots$ \\
\hline Pasture, ${ }^{3} \mathrm{~kg} / \mathrm{d}$ & $6.9^{\mathrm{a}}$ & $4.2^{\mathrm{b}}$ & $2.2^{\mathrm{c}}$ & - & 0.8 & 0.002 \\
\hline Pasture, ${ }^{4} \mathrm{~kg} / \mathrm{d}$ & 7.7 & 5.7 & 4.3 & • & 0.6 & $\ldots$ \\
\hline Total, kg/d & $19.5^{\mathrm{a}}$ & $19.6^{\mathrm{a}}$ & $20.4^{\mathrm{a}}$ & $24.9^{\mathrm{b}}$ & 0.8 & 0.001 \\
\hline Total, \% BW & $3.33^{\mathrm{a}}$ & $3.14^{\mathrm{a}}$ & $3.41^{\mathrm{a}}$ & $4.12^{b}$ & 0.20 & 0.03 \\
\hline \multicolumn{7}{|l|}{ CP intake } \\
\hline TMR, kg/d & 2.00 & 2.50 & 2.90 & 4.00 & 0.04 & $\ldots$ \\
\hline Pasture, $\mathrm{kg} / \mathrm{d}$ & $1.0^{\mathrm{a}}$ & $0.6^{\mathrm{b}}$ & $0.3^{c}$ & - & 0.11 & 0.002 \\
\hline Total, kg/d & $3.0^{\mathrm{a}}$ & $3.1^{\mathrm{a}}$ & $3.2^{\mathrm{a}}$ & $4.0^{\mathrm{b}}$ & 0.11 & 0.001 \\
\hline \multicolumn{7}{|l|}{ NDF intake } \\
\hline TMR, kg/d & 5.60 & 6.80 & 8.00 & 11.00 & 0.12 & $\ldots$ \\
\hline Pasture, kg/d & $3.1^{\mathrm{a}}$ & $1.9^{\mathrm{b}}$ & $1.0^{\mathrm{c}}$ & • & 0.34 & 0.002 \\
\hline Total, kg/d & $8.7^{\mathrm{a}}$ & $8.7^{\mathrm{a}}$ & $9.0^{\mathrm{a}}$ & $11.0^{\mathrm{b}}$ & 0.34 & 0.001 \\
\hline \multicolumn{7}{|l|}{$\mathrm{NE}_{\mathrm{l}}$ intake $^{5}$} \\
\hline TMR, Mcal/d & 20.2 & 24.7 & 29.1 & 39.8 & 0.4 & $\ldots$ \\
\hline Pasture, Mcal/d & $10.0^{\mathrm{a}}$ & $6.0^{\mathrm{b}}$ & $3.2^{\mathrm{c}}$ & - & 1.1 & 0.002 \\
\hline Total, Mcal/d & $30.2^{\mathrm{a}}$ & $30.7^{\mathrm{a}}$ & $32.2^{\mathrm{a}}$ & $39.8^{b}$ & 1.1 & 0.001 \\
\hline \multicolumn{7}{|l|}{ Total $\operatorname{diet}^{6}$} \\
\hline $\mathrm{F}: \mathrm{C}^{7}$ & $60: 40^{\mathrm{a}}$ & $52: 48^{\mathrm{b}}$ & $46: 54^{\mathrm{c}}$ & $40: 60^{\mathrm{d}}$ & 1.4 & 0.001 \\
\hline $\mathrm{GFE}^{8}$ & $1.62^{\mathrm{a}}$ & $1.54^{\mathrm{a}}$ & $1.65^{\mathrm{a}}$ & $1.33^{\mathrm{b}}$ & 0.10 & 0.03 \\
\hline
\end{tabular}

${ }^{1} 55 \mathrm{~T}=55 \% \mathrm{TMR}+$ pasture, $70 \mathrm{~T}=70 \% \mathrm{TMR}+$ pasture, $85 \mathrm{~T}=85 \% \mathrm{TMR}+$ pasture, $100 \mathrm{~T}=100 \% \mathrm{TMR}^{2} \mathrm{t}=$ treatment.

${ }^{3}$ Pasture consumed (based on pre- and post-grazing herbage mass).

${ }^{4}$ Pasture consumed (based on NRC, 2001).

${ }^{5} \mathrm{NE}_{1}$ for TMR and pasture were 1.60 and $1.45 \mathrm{Mcal} / \mathrm{kg} \mathrm{DM}$, respectively (NRC, 2001).

${ }^{6} \mathrm{DM}$ basis.

${ }^{7}$ Forage-to-concentrate ratio.

${ }^{8}$ Gross feed efficiency $=($ FCM yield, $\mathrm{kg} / \mathrm{d}) /(\mathrm{DMI}, \mathrm{kg} / \mathrm{d})$

a, b, c, d Least squares means in the same row with different superscripts differ $(P \leq 0.05)$. 
Table 9. Milk production and milk composition of cows offered varying amounts of TMR and grazing pasture, Experiment 1, F2004.

\begin{tabular}{|c|c|c|c|c|c|c|}
\hline \multirow[b]{2}{*}{ Item } & \multicolumn{4}{|c|}{ Treatments $^{1}$} & \multirow[b]{2}{*}{ SEM } & \multirow{2}{*}{$\begin{array}{c}P \leq^{2} \\
t\end{array}$} \\
\hline & $55 \mathrm{~T}$ & 70T & $85 T$ & $100 \mathrm{~T}$ & & \\
\hline Milk, kg/d & $32.9^{\mathrm{de}}$ & $30.0^{\mathrm{e}}$ & $33.2^{\mathrm{d}}$ & $34.1^{\mathrm{d}}$ & 1.5 & 0.06 \\
\hline $4 \%$ FCM, kg/d & 32.6 & 30.8 & 31.7 & 32.3 & 1.8 & 0.82 \\
\hline Fat, $\%$ & 3.89 & 4.07 & 3.76 & 3.63 & 0.20 & 0.33 \\
\hline Fat, kg/d & 1.29 & 1.23 & 1.23 & 1.25 & 0.09 & 0.96 \\
\hline Protein, $\%$ & $2.84^{\mathrm{a}}$ & $3.12^{b}$ & $2.92^{\mathrm{a}}$ & $2.94^{\mathrm{ab}}$ & 0.08 & 0.007 \\
\hline Protein, kg/d & 0.94 & 0.94 & 0.96 & 1.00 & 0.05 & 0.76 \\
\hline Lactose, $\%$ & $4.75^{\mathrm{d}}$ & $4.94^{\mathrm{d}}$ & $4.91^{\mathrm{d}}$ & $5.17^{\mathrm{e}}$ & 0.09 & 0.09 \\
\hline $\mathrm{SNF}, \%$ & 8.60 & 8.97 & 8.92 & 9.08 & 0.14 & 0.33 \\
\hline MUN, mg/dl & 13.9 & 13.7 & 13.9 & 12.7 & 0.63 & 0.40 \\
\hline $\mathrm{SCC}^{3}$ & $271^{\mathrm{de}}$ & $596^{\mathrm{d}}$ & $261^{\mathrm{de}}$ & $84^{\mathrm{e}}$ & 186 & 0.08 \\
\hline $\mathrm{SCC}^{3}$ min & 20 & 13 & 15 & 12 & & \\
\hline $\mathrm{SCC}^{3}$ max & 3856 & 6762 & 1519 & 867 & & \\
\hline $\mathrm{SCS}^{4}$ & $2.93^{\mathrm{ab}}$ & $4.04^{\mathrm{a}}$ & $3.12^{\mathrm{a}}$ & $1.53^{b}$ & 0.74 & 0.03 \\
\hline \multicolumn{7}{|c|}{$\begin{array}{l}{ }^{1} 55 \mathrm{~T}=55 \% \mathrm{TMR}+\text { pasture, } 70 \mathrm{~T}=70 \% \mathrm{TMR}+\text { pasture, } 85 \mathrm{~T}=85 \% \mathrm{TMR}+\text { pasture, } \\
100 \mathrm{~T}=100 \% \mathrm{TMR} . \\
{ }^{2} \mathrm{t}=\text { treatment. }\end{array}$} \\
\hline \multicolumn{7}{|c|}{${ }^{3}$ Somatic cell counts, number of cells $/ \mathrm{ml}$ milk $\left(10^{3}\right.$ cells $\left./ \mathrm{ml}\right)$. } \\
\hline \multicolumn{7}{|c|}{${ }^{4}$ Somatic cell score $=\left(\left(\log _{10}(\mathrm{SCC} / 1000)-2\right) / \log _{10}(2)\right)+3$} \\
\hline
\end{tabular}


Table 10. Milk production and milk composition of cows offered varying amounts of TMR and grazing pasture, Experiment 2, S2005.

\begin{tabular}{|c|c|c|c|c|c|c|}
\hline \multirow[b]{2}{*}{ Item } & \multicolumn{4}{|c|}{ Treatments ${ }^{1}$} & \multirow[b]{2}{*}{ SEM } & \multirow{2}{*}{$\frac{P \leq^{2}}{t}$} \\
\hline & $55 \mathrm{~T}$ & $70 \mathrm{~T}$ & $85 \mathrm{~T}$ & $100 \mathrm{~T}$ & & \\
\hline Milk, kg/d & $32.7^{\mathrm{a}}$ & $31.9^{\mathrm{a}}$ & $36.7^{\mathrm{b}}$ & $36.6^{\mathrm{b}}$ & 1.6 & 0.001 \\
\hline $4 \% \mathrm{FCM}, \mathrm{kg} / \mathrm{d}$ & $30.8^{\mathrm{ab}}$ & $29.8^{\mathrm{a}}$ & $34.0^{\mathrm{c}}$ & $32.6^{\mathrm{bc}}$ & 1.4 & 0.001 \\
\hline Fat, \% & 3.68 & 3.50 & 3.50 & 3.31 & 0.14 & 0.28 \\
\hline Fat, $\mathrm{kg} / \mathrm{d}$ & $1.18^{\mathrm{d}}$ & $1.13^{\mathrm{d}}$ & $1.29^{\mathrm{e}}$ & $1.19^{\mathrm{de}}$ & 0.06 & 0.08 \\
\hline Protein, \% & 2.86 & 2.91 & 2.84 & 2.84 & 0.04 & 0.27 \\
\hline Protein, $\mathrm{kg} / \mathrm{d}$ & $0.93^{\mathrm{a}}$ & $0.93^{\mathrm{a}}$ & $1.04^{\mathrm{b}}$ & $1.04^{\mathrm{b}}$ & 0.04 & 0.001 \\
\hline Lactose, $\%$ & 4.88 & 4.82 & 4.90 & 4.94 & 0.05 & 0.13 \\
\hline SNF, \% & 8.62 & 8.68 & 8.70 & 8.76 & 0.09 & 0.52 \\
\hline MUN, mg/dl & $9.1^{\mathrm{a}}$ & $9.7^{\mathrm{a}}$ & $10.2^{\mathrm{a}}$ & $14.1^{\mathrm{b}}$ & 0.6 & 0.001 \\
\hline $\mathrm{SCC}^{3}$ & 114 & 160 & 252 & 122 & 55 & 0.14 \\
\hline $\mathrm{SCC}^{3}, \min$ & 15 & 20 & 16 & 20 & & \\
\hline $\mathrm{SCC}^{3}, \max$ & 714 & 2050 & 1268 & 753 & & \\
\hline $\mathrm{SCS}^{4}$ & $2.41^{\mathrm{a}}$ & $2.65^{\mathrm{ab}}$ & $3.27^{\mathrm{b}}$ & $2.16^{\mathrm{a}}$ & 0.37 & 0.03 \\
\hline
\end{tabular}

${ }^{1} 55 \mathrm{~T}=55 \% \mathrm{TMR}+$ pasture, $70 \mathrm{~T}=70 \% \mathrm{TMR}+$ pasture, $85 \mathrm{~T}=85 \% \mathrm{TMR}+$ pasture, $100 \mathrm{~T}=100 \% \mathrm{TMR}$.

${ }^{2} \mathrm{t}=$ treatment.

${ }^{3}$ Somatic cell counts, number of cells $/ \mathrm{ml}$ milk $\left(10^{3}\right.$ cells $\left./ \mathrm{ml}\right)$.

${ }^{4}$ Somatic cell score $=\left(\left(\log _{10}(\mathrm{SCC} / 1000)-2\right) / \log _{10}(2)\right)+3$

${ }^{\mathrm{a}, \mathrm{b}, \mathrm{c}}$ Least squares means in the same row with different superscripts $\operatorname{differ}(P \leq 0.05)$.

${ }^{\mathrm{d}, \mathrm{e}}$ Least squares means in the same row with different superscripts $\operatorname{differ}(P \leq 0.10)$. 
Table 11. Fatty acid profiles of TMR and pasture grazed by cows in the fall (F2004) and spring (S2005).

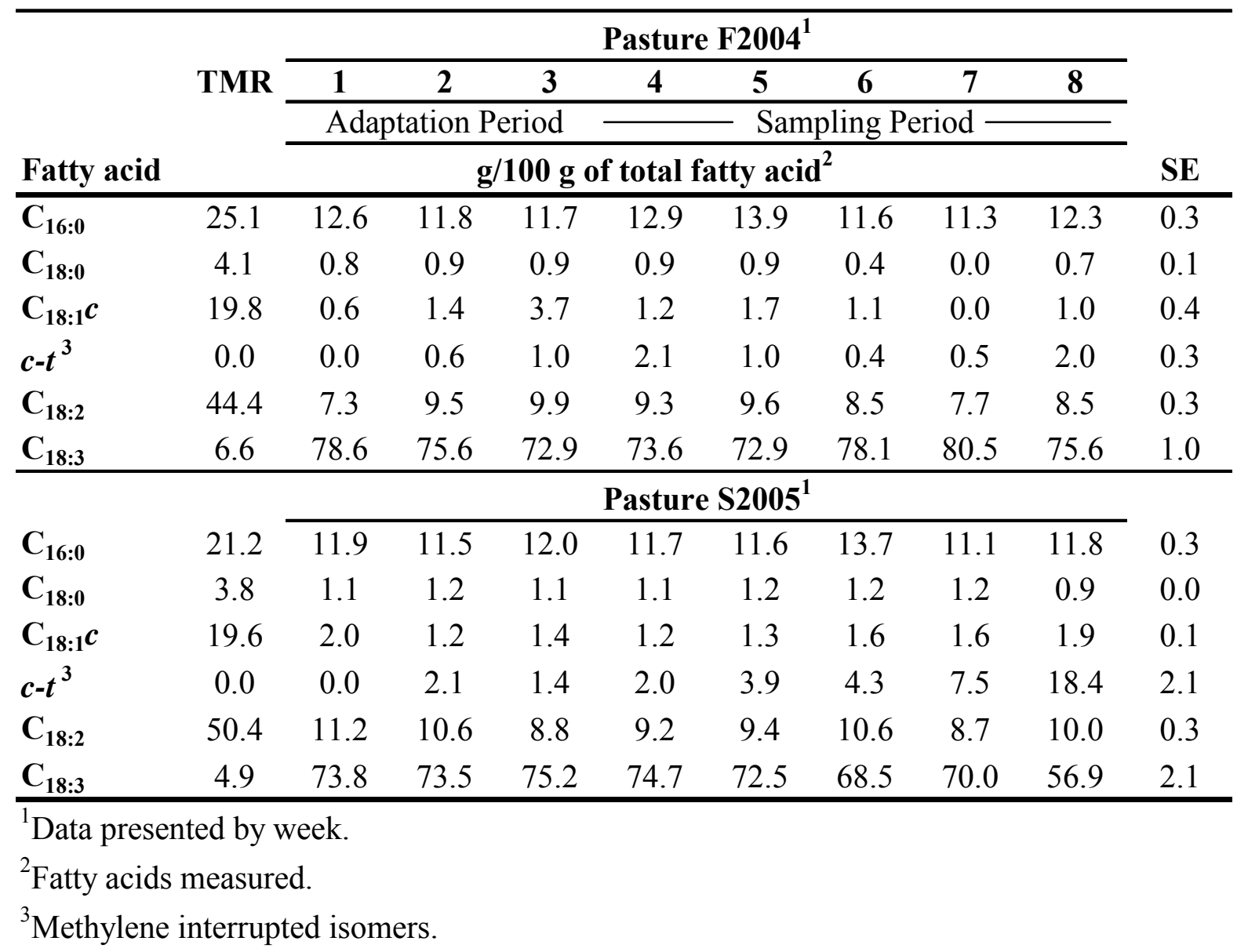


Table 12. Milk fatty acid composition from cows offered varying amounts of TMR and grazing pasture, Experiment 1, F2004.

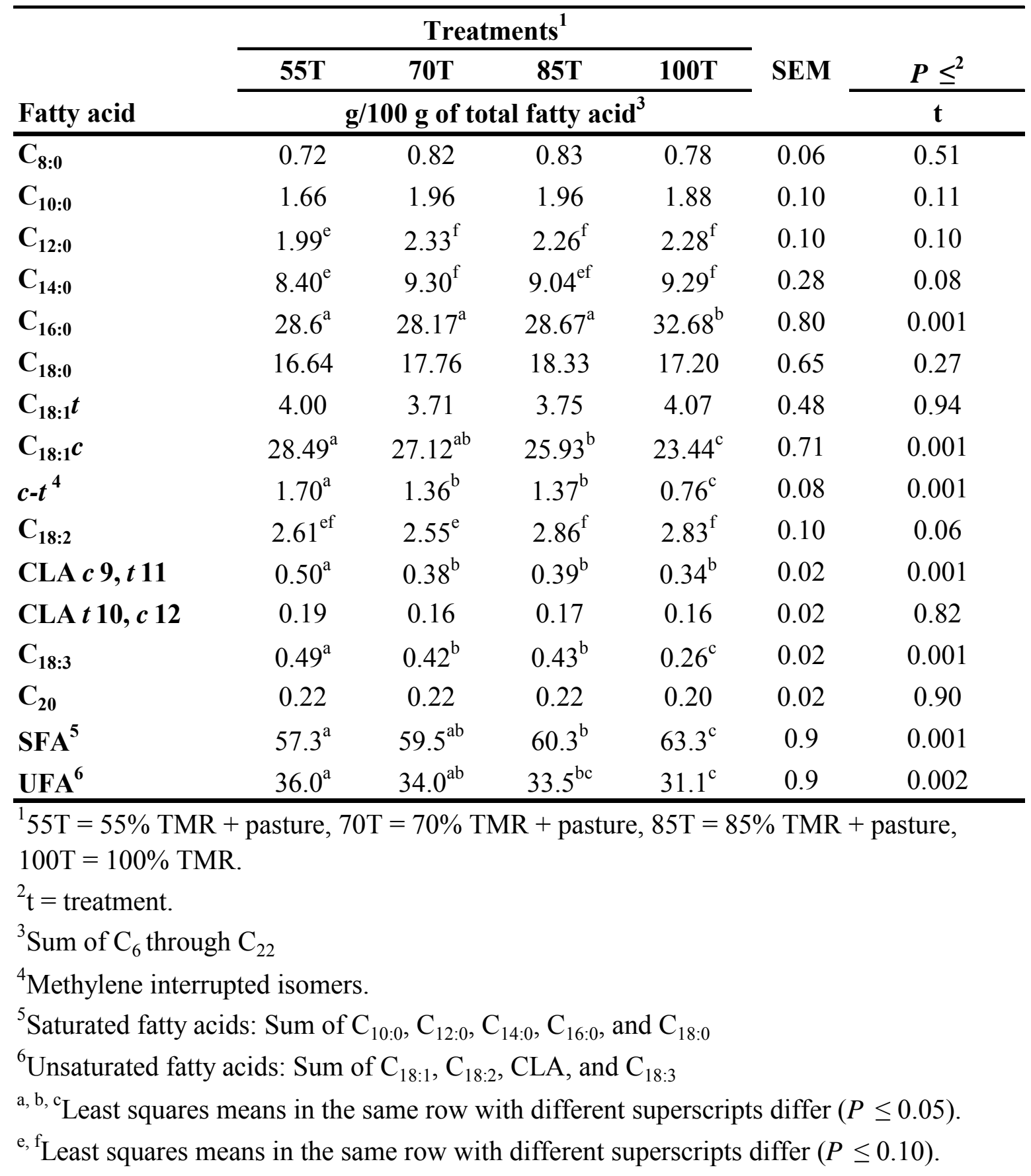


Table 13. Milk fatty acid composition from cows offered varying amounts of TMR and grazing pasture, Experiment 2, S2005.

\begin{tabular}{|c|c|c|c|c|c|c|}
\hline \multirow[b]{3}{*}{ Fatty acid } & \multicolumn{4}{|c|}{ Treatments $^{1}$} & \multirow{3}{*}{ SEM } & \multirow{3}{*}{$\frac{P \leq^{2}}{t}$} \\
\hline & $55 \mathrm{~T}$ & $70 \mathrm{~T}$ & $85 T$ & $100 \mathrm{~T}$ & & \\
\hline & \multicolumn{4}{|c|}{$\mathrm{g} / 100 \mathrm{~g}$ of total fatty acid $^{3}$} & & \\
\hline $\mathrm{C}_{8: 0}$ & 0.64 & 0.66 & 0.71 & 0.65 & 0.05 & 0.79 \\
\hline $\mathrm{C}_{10: 0}$ & 1.85 & 1.91 & 2.04 & 1.93 & 0.10 & 0.65 \\
\hline $\mathrm{C}_{12: 0}$ & 2.33 & 2.22 & 2.34 & 2.37 & 0.11 & 0.79 \\
\hline$C_{14: 0}$ & 9.65 & 9.84 & 9.84 & 9.99 & 0.28 & 0.87 \\
\hline $\mathrm{C}_{16: 0}$ & $29.40^{\mathrm{ab}}$ & $29.18^{\mathrm{a}}$ & $30.10^{\mathrm{b}}$ & $31.16^{\mathrm{c}}$ & 0.45 & 0.001 \\
\hline $\mathrm{C}_{18: 0}$ & 18.46 & 18.37 & 18.74 & 18.12 & 0.36 & 0.70 \\
\hline $\mathrm{C}_{18: 1} t$ & $3.32^{\mathrm{a}}$ & $3.21^{\mathrm{ab}}$ & $2.93^{\mathrm{b}}$ & $3.77^{\mathrm{c}}$ & 0.14 & 0.001 \\
\hline $\mathrm{C}_{18: 1} C$ & $26.77^{\mathrm{a}}$ & $27.07^{\mathrm{a}}$ & $25.82^{\mathrm{b}}$ & $25.00^{\mathrm{c}}$ & 0.42 & 0.001 \\
\hline$c-t^{4}$ & $0.87^{\mathrm{a}}$ & $0.80^{\mathrm{a}}$ & $0.81^{\mathrm{a}}$ & $0.66^{\mathrm{b}}$ & 0.04 & 0.003 \\
\hline $\mathrm{C}_{18: 2}$ & $2.74^{\mathrm{e}}$ & $2.88^{\mathrm{ef}}$ & $2.82^{\mathrm{e}}$ & $3.05^{\mathrm{f}}$ & 0.09 & 0.10 \\
\hline CLA $c 9, t 11$ & $0.36^{\mathrm{e}}$ & $0.31^{\mathrm{f}}$ & $0.30^{\mathrm{f}}$ & $0.30^{\mathrm{f}}$ & 0.02 & 0.09 \\
\hline CLA $t$ 10, $c 12$ & 0.06 & 0.05 & 0.07 & 0.05 & 0.01 & 0.31 \\
\hline $\mathrm{C}_{18: 3}$ & $0.53^{\mathrm{a}}$ & $0.48^{\mathrm{a}}$ & $0.50^{\mathrm{a}}$ & $0.39^{\mathrm{b}}$ & 0.04 & 0.04 \\
\hline $\mathbf{C}_{20: 0}$ & $0.34^{\mathrm{e}}$ & $0.27^{\mathrm{f}}$ & $0.29^{\mathrm{ef}}$ & $0.26^{\mathrm{f}}$ & 0.02 & 0.07 \\
\hline $\mathrm{SFA}^{5}$ & $61.6^{\mathrm{a}}$ & $61.5^{\mathrm{a}}$ & $63.0^{\mathrm{b}}$ & $63.5^{\mathrm{b}}$ & 0.5 & 0.001 \\
\hline UFA $^{6}$ & $33.5^{\mathrm{a}}$ & $33.7^{\mathrm{a}}$ & $32.2^{\mathrm{b}}$ & $32.1^{\mathrm{b}}$ & 0.5 & 0.002 \\
\hline \multicolumn{7}{|c|}{$\begin{array}{l}{ }^{1} 55 \mathrm{~T}=55 \% \mathrm{TMR}+\text { pasture, } 70 \mathrm{~T}=70 \% \mathrm{TMR}+\text { pasture, } 85 \mathrm{~T}=85 \% \mathrm{TMR}+\text { pasture, } \\
100 \mathrm{~T}=100 \% \mathrm{TMR} . \\
{ }^{2} \mathrm{t}=\text { treatment. }\end{array}$} \\
\hline \multicolumn{7}{|c|}{${ }^{3}$ Sum of $\mathrm{C}_{6}$ through $\mathrm{C}_{22}$} \\
\hline \multicolumn{7}{|c|}{${ }^{4}$ Methylene interrupted isomers. } \\
\hline \multicolumn{7}{|c|}{${ }^{5}$ Saturated fatty acids: Sum of $\mathrm{C}_{10: 0}, \mathrm{C}_{12: 0}, \mathrm{C}_{14: 0}, \mathrm{C}_{16: 0}$, and $\mathrm{C}_{18: 0}$} \\
\hline \multicolumn{7}{|c|}{${ }^{6}$ Unsaturated fatty acids: Sum of $\mathrm{C}_{18: 1}, \mathrm{C}_{18: 2}$, CLA, and $\mathrm{C}_{18: 3}$} \\
\hline
\end{tabular}


Table 14. Body weights and body condition scores of cows offered varying amounts of TMR and grazing pasture, Experiment 1, F2004.

\begin{tabular}{|c|c|c|c|c|c|c|}
\hline \multirow[b]{2}{*}{ Item } & \multicolumn{4}{|c|}{ Treatments $^{1}$} & \multirow[b]{2}{*}{ SEM } & \multirow{2}{*}{$\frac{P \leq^{2}}{t}$} \\
\hline & $55 \mathrm{~T}$ & $70 \mathrm{~T}$ & $85 \mathrm{~T}$ & 100T & & \\
\hline \multicolumn{7}{|l|}{$\mathbf{B W}^{\mathbf{3}}, \mathbf{k g}$} \\
\hline Mean & $554^{\mathrm{a}}$ & $578^{b}$ & $582^{\mathrm{b}}$ & $577^{\mathrm{b}}$ & 3 & 0.001 \\
\hline Initial $^{4}$ & 558 & 574 & 570 & 581 & 6 & 0.14 \\
\hline Final $^{5}$ & 561 & 581 & 584 & 577 & 8 & 0.31 \\
\hline Change & $3^{\text {ef }}$ & $7^{\mathrm{ef}}$ & $14^{\mathrm{e}}$ & $-4^{\mathrm{f}}$ & 6 & 0.09 \\
\hline \multicolumn{7}{|c|}{ BCS, 1 to 5} \\
\hline Mean & $2.97^{\mathrm{ef}}$ & $2.96^{\mathrm{e}}$ & $3.09^{f}$ & $2.94^{\mathrm{e}}$ & 0.05 & 0.10 \\
\hline Initial $^{4}$ & 2.76 & 2.83 & 2.99 & 3.09 & 0.13 & 0.52 \\
\hline Final $^{5}$ & 3.04 & 2.91 & 3.13 & 2.88 & 0.12 & 0.25 \\
\hline Change & $0.28^{\mathrm{a}}$ & $0.08^{\mathrm{a}}$ & $0.14^{\mathrm{a}}$ & $-0.21^{b}$ & 0.08 & 0.03 \\
\hline
\end{tabular}

${ }^{1} 55 \mathrm{~T}=55 \% \mathrm{TMR}+$ pasture, $70 \mathrm{~T}=70 \% \mathrm{TMR}+$ pasture, $85 \mathrm{~T}=85 \% \mathrm{TMR}+$ pasture, $100 \mathrm{~T}=100 \% \mathrm{TMR}$.

${ }^{2} \mathrm{t}=$ treatment.

${ }^{3}$ Mean weight of measurements taken on two consecutive days.

${ }^{4}$ Week 5.

${ }^{5}$ Week 8.

${ }^{\mathrm{a}, \mathrm{b}}$ Least squares means in the same row with different superscripts $\operatorname{differ}(P \leq 0.05)$.

${ }^{\mathrm{e}, \mathrm{f}}$ Least squares means in the same row with different superscripts $\operatorname{differ}(P \leq 0.10)$. 
Table 15. Body weights and body condition scores of cows offered varying amounts of TMR and grazing pasture, Experiment 2, S2005.

\begin{tabular}{|c|c|c|c|c|c|c|}
\hline \multirow[b]{2}{*}{ Item } & \multicolumn{4}{|c|}{ Treatments $^{1}$} & \multirow[b]{2}{*}{ SEM } & \multirow{2}{*}{$\frac{P \leq^{2}}{t}$} \\
\hline & $55 \mathrm{~T}$ & 70T & $85 T$ & 100T & & \\
\hline \multicolumn{7}{|l|}{$\mathbf{B W}^{3}, \mathbf{k g}$} \\
\hline Mean & 615 & 617 & 612 & 615 & 3 & 0.66 \\
\hline Initial $^{4}$ & $603^{a}$ & $607^{\mathrm{a}}$ & $597^{\mathrm{a}}$ & $626^{\mathrm{b}}$ & 5 & 0.005 \\
\hline Final $^{5}$ & 622 & 625 & 619 & 611 & 6 & 0.44 \\
\hline Change & $19^{\mathrm{a}}$ & $18^{\mathrm{a}}$ & $22^{\mathrm{a}}$ & $-15^{\mathrm{b}}$ & 4 & 0.001 \\
\hline \multicolumn{7}{|c|}{ BCS, 1 to 5} \\
\hline Mean & $3.00^{\mathrm{ab}}$ & $3.07^{\mathrm{a}}$ & $2.91^{\mathrm{b}}$ & $3.00^{\mathrm{ab}}$ & 0.05 & 0.03 \\
\hline Initial $^{4}$ & 3.06 & 3.14 & 2.91 & 3.11 & 0.09 & 0.26 \\
\hline Final $^{5}$ & 3.03 & 3.12 & 2.95 & 3.04 & 0.10 & 0.66 \\
\hline Change & -0.03 & -0.02 & 0.04 & -0.07 & 0.08 & 0.82 \\
\hline
\end{tabular}

${ }^{1} 55 \mathrm{~T}=55 \% \mathrm{TMR}+$ pasture, $70 \mathrm{~T}=70 \% \mathrm{TMR}+$ pasture, $85 \mathrm{~T}=85 \% \mathrm{TMR}+$ pasture, $100 \mathrm{~T}=100 \% \mathrm{TMR}$.

${ }^{2} \mathrm{t}=$ treatment.

${ }^{3}$ Mean weight of measurements taken on two consecutive days.

${ }^{4}$ Week 5.

${ }^{5}$ Week 8 .

${ }^{\mathrm{a}, \mathrm{b}}$ Least squares means in the same row with different superscripts $\operatorname{differ}(P \leq 0.05)$. 
Table 16. Plasma metabolites of cows offered varying amounts of TMR and grazing pasture, Experiment 2, S2005.

\begin{tabular}{|c|c|c|c|c|c|c|}
\hline \multirow[b]{2}{*}{ Item } & \multicolumn{4}{|c|}{ Treatments $^{1}$} & \multirow[b]{2}{*}{ SEM } & \multirow{2}{*}{$\frac{P \leq^{2}}{t}$} \\
\hline & $55 \mathrm{~T}$ & $70 T$ & $85 T$ & $100 \mathrm{~T}$ & & \\
\hline \multicolumn{7}{|l|}{ Plasma $^{3}$} \\
\hline \multicolumn{7}{|c|}{$\mathrm{NEFA}^{4}, \mathrm{meq} / \mathrm{L}$} \\
\hline wk 5 & $276.0^{\mathrm{y}}$ & $230.7^{y}$ & $219.7^{\mathrm{y}}$ & 198.0 & 30.2 & 0.23 \\
\hline wk 8 & $85.9^{\mathrm{z}, \mathrm{a}}$ & $85.0^{\mathrm{z}, \mathrm{a}}$ & $106.6^{\mathrm{z}, \mathrm{a}}$ & $185.3^{\mathrm{b}}$ & 26.8 & 0.04 \\
\hline \multicolumn{7}{|c|}{$\mathrm{PUN}^{5}, \mathrm{mg} / \mathrm{dl}$} \\
\hline wk 5 & $9.6^{\mathrm{a}}$ & $11.1^{\mathrm{a}}$ & $11.3^{\mathrm{a}}$ & $16.3^{b}$ & 0.8 & 0.001 \\
\hline wk 6 & $9.4^{\mathrm{a}}$ & $10.0^{\mathrm{a}}$ & $10.2^{\mathrm{a}}$ & $16.1^{\mathrm{b}}$ & 0.8 & 0.001 \\
\hline wk 7 & $7.2^{\mathrm{a}}$ & $6.9^{\mathrm{a}}$ & $7.3^{\mathrm{a}}$ & $11.6^{\mathrm{b}}$ & 0.5 & 0.001 \\
\hline wk 8 & $6.1^{\mathrm{a}}$ & $6.7^{\mathrm{a}}$ & $7.2^{\mathrm{a}}$ & $12.4^{\mathrm{b}}$ & 0.5 & 0.001 \\
\hline \multicolumn{7}{|c|}{ Glucose, $\mathrm{mg} / \mathrm{dl}$} \\
\hline wk 5 & $58.9^{\mathrm{a}}$ & $60.5^{\mathrm{ab}}$ & $59.5^{\mathrm{a}}$ & $63.2^{\mathrm{b}}$ & 1.0 & 0.05 \\
\hline wk 6 & 57.5 & 58.4 & 57.5 & 62.7 & 1.4 & 0.11 \\
\hline wk 7 & 55.2 & 56.7 & 55.4 & 58.8 & 2.3 & 0.69 \\
\hline wk 8 & 58.7 & 62.0 & 59.7 & 62.6 & 1.4 & 0.21 \\
\hline
\end{tabular}

${ }^{1} 55 \mathrm{~T}=55 \% \mathrm{TMR}+$ pasture, $70 \mathrm{~T}=70 \% \mathrm{TMR}+$ pasture, $85 \mathrm{~T}=85 \% \mathrm{TMR}+$ pasture, $100 \mathrm{~T}=100 \% \mathrm{TMR}$.

${ }^{2} \mathrm{t}=$ treatment.

${ }^{3}$ Samples were collected during week 1 and from weeks 5 to 8 .

${ }^{4}$ Non-esterified fatty acids.

${ }^{5}$ Plasma urea nitrogen.

${ }^{\mathrm{a}, \mathrm{b}}$ Least squares means in the same row with different superscripts $\operatorname{differ}(P \leq 0.05)$.

${ }^{\mathrm{y}, \mathrm{z}}$ Least squares means in the same column with different superscripts differ $(P \leq 0.05)$. 


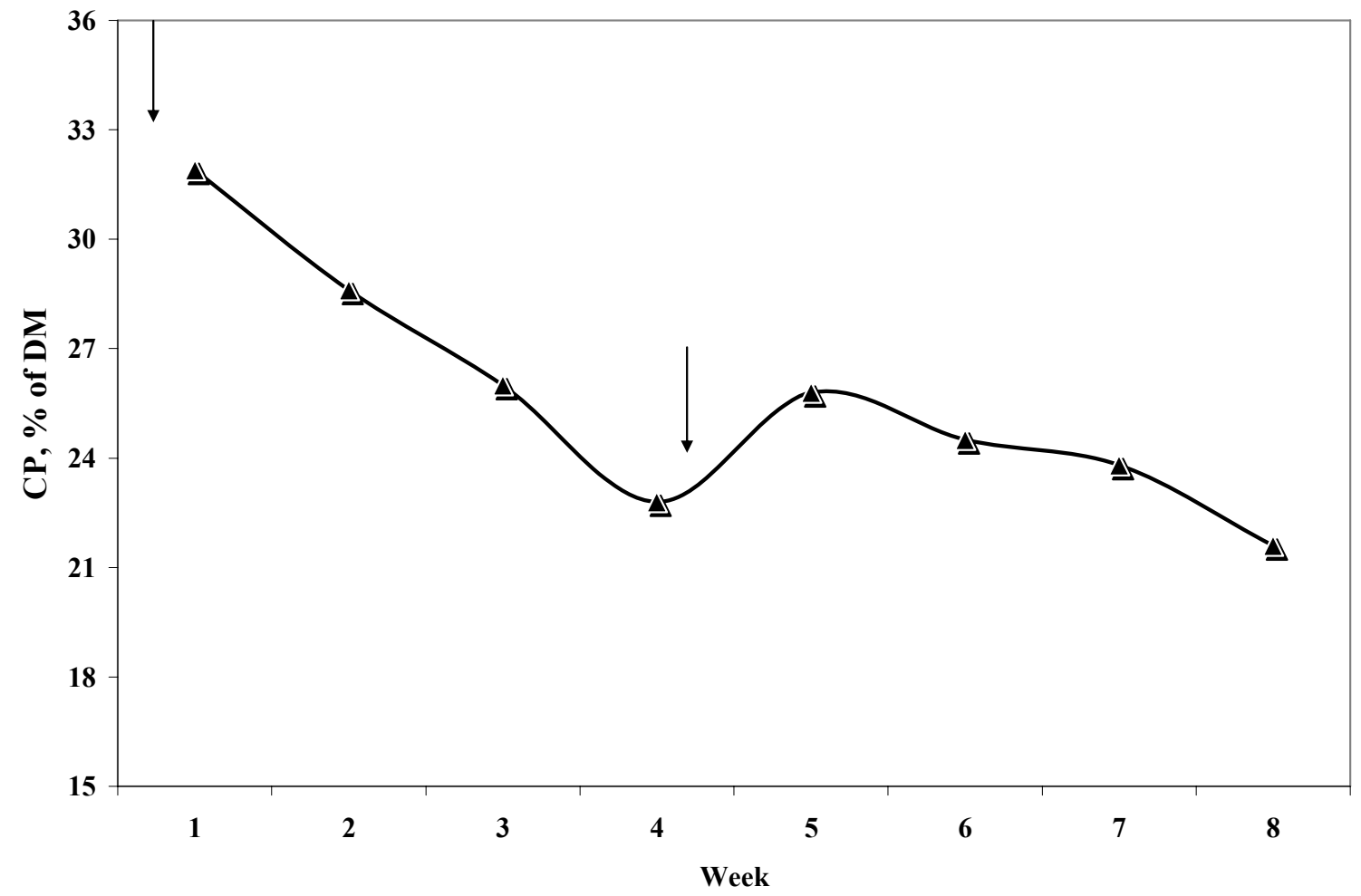

Figure 1. Crude protein concentration of hand-plucked weekly composite samples of annual ryegrass (Experiment 1, F2004). Arrows indicate fertilization with $32.6 \mathrm{~kg} \mathrm{~N} / \mathrm{ha}$ before the initiation of the experiment (October 4, 2004) and with $22.6 \mathrm{~kg} / \mathrm{ha}$ during the mid-grazing season (November 18, 2004). 


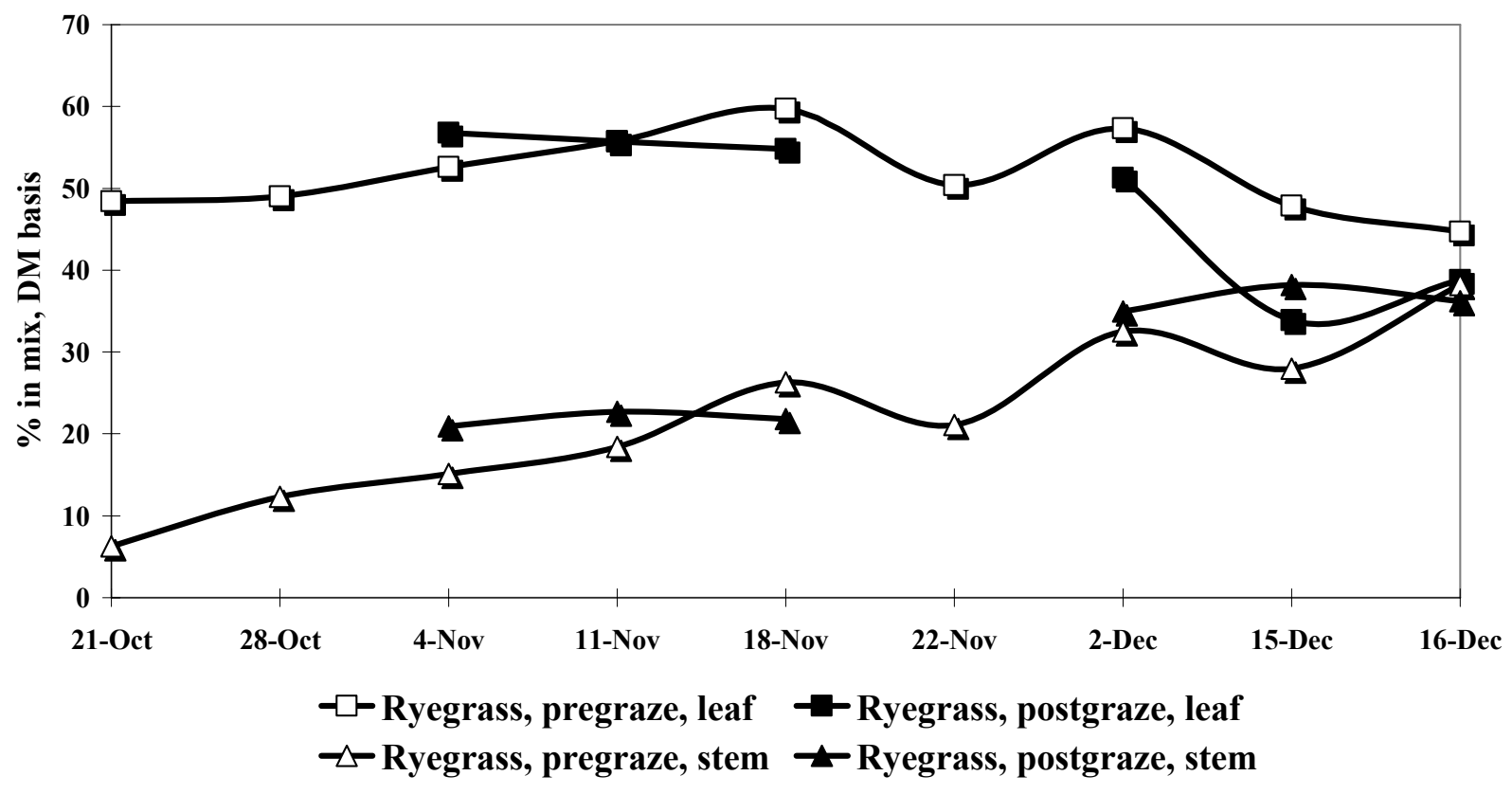

Figure 2. Average percentage of leaf and stem fractions of annual ryegrass (DM basis) in the fall of 2004 (Experiment 1, F2004). 


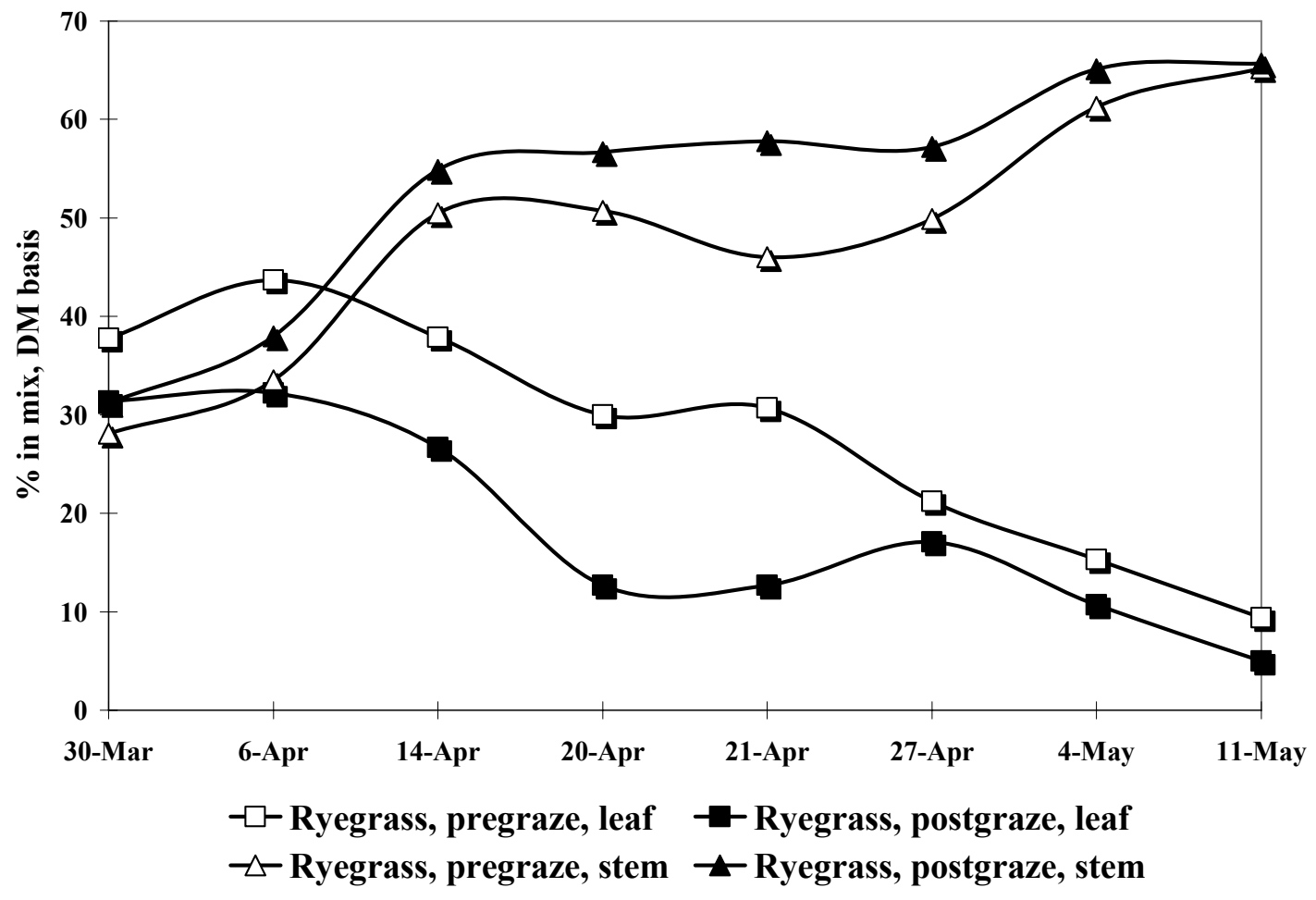

Figure 3. Average percentage of leaf and stem fractions of annual ryegrass (DM basis) in the spring of 2005 (Experiment 2, S2005). 


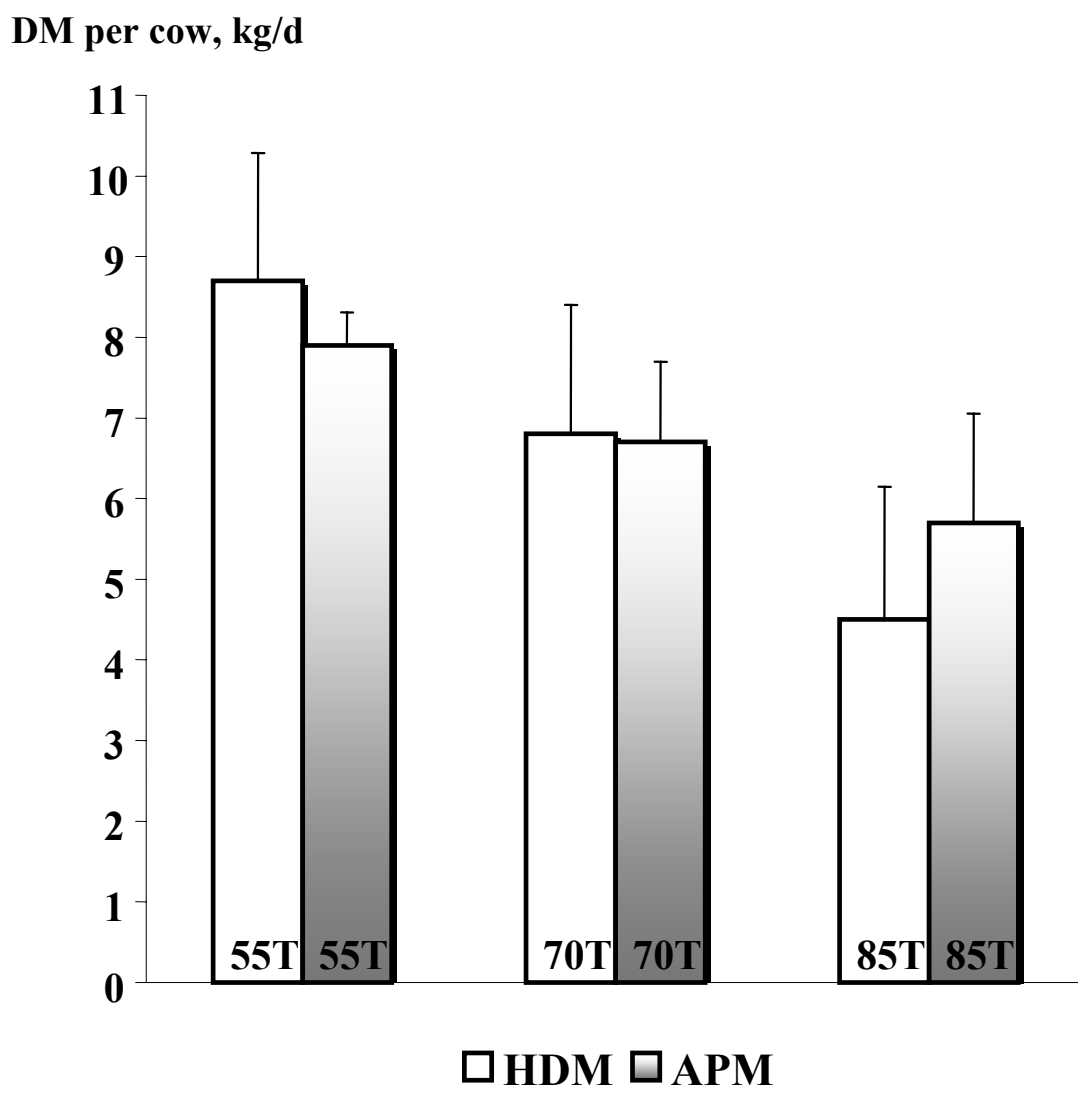

Figure 4. Average pasture DMI estimated using a herbage mass disappearance method (HDM) and an animal performance method (APM) of cows offered varying amounts of TMR and grazing pasture in the fall of 2004, Experiment 1, F2004 $(55 \mathrm{~T}=55 \% \mathrm{TMR}+$ pasture; $70 \mathrm{~T}=70 \% \mathrm{TMR}+$ pasture $; 85 \mathrm{~T}=85 \% \mathrm{TMR}+$ pasture $).$ 


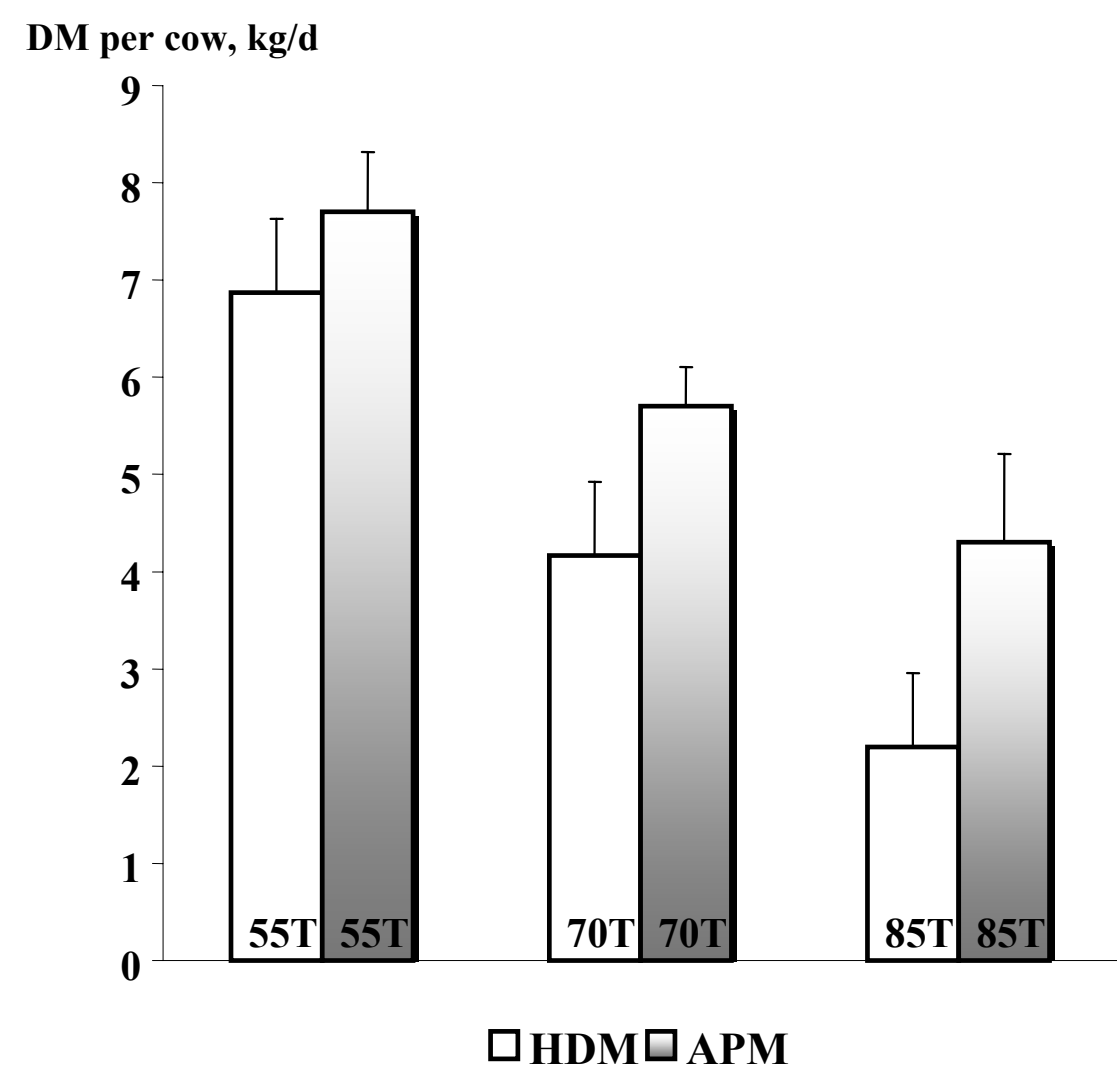

Figure 5. Average pasture DMI estimated using a herbage mass disappearance method (HDM) and an animal performance method (APM) of cows offered varying amounts of TMR and grazing pasture in the spring of 2005, Experiment 2, S2005 $(55 \mathrm{~T}=55 \% \mathrm{TMR}+$ pasture; $70 \mathrm{~T}=70 \% \mathrm{TMR}+$ pasture; $85 \mathrm{~T}=85 \% \mathrm{TMR}+$ pasture $).$ 


\section{CHAPTER 4}

CONTINUOUS CULTURE FERMENTATION OF DAIRY DIETS WITH VARYING LEVELS OF TOTAL MIXED RATION AND FORAGE 


\begin{abstract}
Four dual-flow continuous culture vessels (700 ml plus headspace) were used to examine ruminal fermentation patterns including intermediate and end products of fermentation to better understand the milk production responses obtained from four dietary treatments tested previously in two field trials. Dietary treatments included a nutritionallybalanced TMR (100T) and the following three TMR-pasture combinations (DM basis): a) $85 \%$ TMR plus $15 \%$ pasture (85T) b) $70 \%$ TMR plus $30 \%$ pasture (70T) and c) $55 \%$ TMR plus $45 \%$ pasture (55T). All cultures were fed equal amounts of DM (20 g/d). Diets were tested in a randomized complete block design with repeated measurements. The pasture portion of the three TMR-restricted treatments was annual ryegrass harvested selectively at a height that simulated the animal diet during the spring of 2005. Ruminal variables examined included ruminal culture $\mathrm{pH}$, methane production, $\mathrm{NH}_{3}-\mathrm{N}$ concentration and output, VFA molar proportions and production, and microbial protein synthesis. Total substrate offered to the vessels was partitioned into the amount fermented to VFA, gas $\left(\mathrm{CH}_{4}\right.$ plus $\left.\mathrm{CO}_{2}\right)$, and microbial biomass. Because of the substitution of TMR with increasing amounts of pasture, diets offered to the fermentors exhibited forage/concentrate ratios that ranged from 40:60 (100T) to $67: 33(55 \mathrm{~T})$. Increasing the amount of pasture offered to the fermentors altered the molar proportions and daily production of VFA. Treatment 55T tended $(P=0.08)$ to yield the greatest amounts of total VFA $(108.0 \mathrm{mmol} / \mathrm{d})$, followed by treatment $85 \mathrm{~T}(98.7$ $\mathrm{mmol} / \mathrm{d})$. Methane production was greatest $(P<0.05)$ for the all-TMR diet $(42.5 \mathrm{mmol} / \mathrm{d})$ and lowest for 70T $(16.6 \mathrm{mmol} / \mathrm{d})$. Reduced $(P<0.05)$ apparent and true OM degradability was reported for the treatments that exhibited the lowest $\mathrm{pH}$ values (5.65 and 5.68 for dietary treatments $70 \mathrm{~T}$ and $100 \mathrm{~T}$, respectively). Increasing the amount of forage offered to
\end{abstract}


continuous cultures resulted in increased $(P<0.05)$ acetate/propionate and (acetate plus butyrate)/propionate ratios, daily microbial biomass yield (g/d) and microbial DM flow (g/d), and decreased methane production. Although ruminal $\mathrm{NH}_{3}-\mathrm{N}$ concentration and daily flow was similar for all diets, increasing the amount of forage resulted in improved $\mathrm{N}$ capture by ruminal microorganisms. Based on total VFA and gas production, ruminal culture $\mathrm{pH}$, and true fermentability, two distinct ruminal fermentation patterns were observed for diets 55T and $85 \mathrm{~T}$ vs. $70 \mathrm{~T}$ and $100 \mathrm{~T}$. Overall, the testing of diets using continuous culture fermentation was extremely useful in elucidating some of the intricate ruminant physiology that likely affects lactation performance.

(Key words: pasture, total mixed ration, ruminal degradability, fermentability, microbial biomass) 


\section{INTRODUCTION}

High-producing dairy cows fed a nutritionally balanced TMR typically produce more milk and milk constituents than those fed pasture-based diets (Kolver and Muller, 1998; Soriano et al., 2001; Tucker et al., 2001; Bargo et al., 2002a; White et al., 2002; Fontaneli et

al., 2005). Lower lactation performance from pasture-based diets may be related both to decreased levels of intake and alterations in ruminal fermentation and digestion (Bargo et al., 2002b). Ruminal digestion is characterized by the degradation and fermentation of ingested carbohydrates, proteins, and other feed constituents. Ruminal environments from grazing fresh, cool-season grasses in a vegetative state compared to ruminal environments of cows consuming a TMR are often characterized by 1) a greater concentration of soluble proteins with a greater rate and extent of ruminal degradation (Beever and Siddons, 1984; van Vuuren et al., 1991; Tas et al., 2006) 2) a greater proportion of NDF that is readily fermentable (Steg et al., 1994) 3) a lower proportion of NDF that is considered effective in stimulating chewing activity (Mertens, 1994) and 4) reduced $\mathrm{pH}(<6.0)$. The first two characteristics result in rapid production of ruminal volatile fatty acids (VFA; Holden et al., 1994; Clark et al., 1997). Lower proportions of effective NDF lead to decreased ruminal buffering effects of saliva (Mertens, 1994). The combination of high VFA production and hindered buffering effects are most likely to cause the low ruminal $\mathrm{pH}$ measured in pasture-fed cows (de Veth and Kolver, 2001; Doyle et al., 2005).

Further, ruminal environments from cows grazing high-quality pastures $(<50 \%$ NDF) supplemented with concentrates are often characterized by low acetate/propionate ratios, high ammonia $\mathrm{N}\left(\mathbf{N H}_{3}-\mathbf{N}\right)$ concentrations, and high rates of passage (Holden et al., 1994; Bargo et al., 2001). Simultaneous consumption of fiber and nonstructural 
carbohydrates (NSC) from TMR diets allows for increased chewing and salivation, leading to increased ruminal buffering capacity while the NSC fraction is being fermented (NRC, 2001).

Supplementing a pasture-based diet with a TMR rather than with a grain-based concentrate has resulted in improved lactation performance (Bargo et al, 2002a). Improved lactation performance is associated with increased total DMI, improved ruminal $\mathrm{pH}$ stability, and improved $\mathrm{N}$ utilization from forage sources that are greater in effective fiber and lower in CP concentration (Bargo et al., 2002b). Published information describing ruminal function and dynamics from feeding systems that use both pasture and TMR, however, is limited in the U.S. In two companion field experiments we compared total DMI, milk production and composition, and feed efficiency of cows consuming a nutritionally-balanced TMR with cows that had access to three different levels of TMR and pasture. The objective of this study was to examine ruminal fermentation patterns, intermediates, and end products of fermentation to better understand the production responses obtained from the different dietary treatments using a dual-flow continuous culture system. Ruminal variables examined included ruminal culture $\mathrm{pH}$, methane $\left(\mathbf{C H}_{4}\right)$ production, $\mathrm{NH}_{3}-\mathrm{N}$ concentration and output, VFA production, and microbial protein synthesis. I hypothesized that a nutritionallybalanced TMR would maximize post-ruminal total nutrient and protein supply, but proportional microbial protein supply will be increased with increasing levels of high nutritive value forage in the diets.

\section{MATERIALS AND METHODS}

\section{Dietary Treatments and Continuous Culture Conditions}

A four-unit, dual flow, continuous culture system holding approximately $700 \mathrm{ml}$ of 
strained inoculum each was used to compare four dietary treatments in a randomized complete block design with repeated measurements. Dietary treatments were randomly assigned to fermentation vessels and included a nutritionally-balanced TMR (100T) and the following three TMR-forage combinations (DM basis): a) $85 \%$ TMR and 15\% pasture (85T) b) $70 \% \mathrm{TMR}$ and $30 \%$ pasture (70T) and c) $55 \% \mathrm{TMR}$ and $45 \%$ pasture (55T). The forage portion representing pasture in the three TMR-restricted treatments was freeze-dried annual ryegrass.

A mature, non-lactating, ruminally cannulated Holstein cow consuming a predominantly forage diet (alfalfa and orchardgrass hay with free access to a mineral block) was used as the source of the rumen inoculum. Whole ruminal contents were extracted at the initiation of each fermentation period using a hand pump, placed in a pre-heated insulated container, immediately transported to the laboratory, and filtered through double-layered cheesecloth before placing in the fermentors. Prior to the addition of ruminal fluid, the system was purged with $\mathrm{CO}_{2}$ gas and maintained at a fixed flow of $20 \mathrm{ml} \mathrm{CO} / \mathrm{min}$ mimicking anaerobic conditions in the rumen. The temperature of the vessels was maintained with a circulating water bath $\left(39^{\circ} \mathrm{C}\right)$ and ruminal contents were stirred at a set speed of approximately $10 \mathrm{rpm}$ with the aid of a central paddle device. Evaluation and validation of the efficacy of the continuous dual-flow system such as the one described here in simulating ruminal fermentation has been documented (Fellner et al., 1997; Jenkins et al., 2003; Eun et al., 2004a, 2004b). Each fermentor is equipped with an overflow system that includes a glass device with a ' $\mathrm{T}$ ' shape located near the bottom of the suspended particle phase that allows for a naturally compartmented rumen simulation system (Teather and Sauer, 1988; Eun et al., 2004b). Artificial saliva, prepared according to guidelines provided by Slyter et al. (1966), 
was delivered continuously at $1.16 \mathrm{ml} / \mathrm{min}$, resulting in a liquid dilution rate of approximately $10.0 \% / \mathrm{h}$ or 2.39 daily volume turnovers. Also, a calculated solids dilution rate of $4.6 \% / \mathrm{h}$ (Eun et al., 2004a) resulted in a mean solids retention time of $22 \mathrm{~h}$. The values for liquid and solid dilution rates resemble closely those reported by studies conducted with high-producing dairy cows fed pasture-based diets (Reis and Combs, 2000a, 2000b).

\section{Feeding Schedule, Sampling and Analyses, and Fermentation Assessment}

Following the inoculation of the vessels, microbial populations were allowed to stabilize for $48 \mathrm{~h}$ before experimental diets were added. During the stabilization period, ruminal cultures received alfalfa pellets $(20 \mathrm{~g} \mathrm{DM} / \mathrm{d})$ in two equal aliquots at 0900 and 1500 h. After $2 \mathrm{~d}$ of stabilization, experimental diets were gradually introduced over a $48-\mathrm{h}$ period, as follows: on day 3 , all of the fermentors received a mixed diet consisting of $50 \%$ alfalfa pellets (10 g DM) and 50\% experimental diets (10 g DM); on day 4, the fermentors received a mixed diet consisting of $30 \%$ alfalfa pellets $(6 \mathrm{~g} \mathrm{DM})$ and $70 \%$ experimental diets (14 g $\mathrm{DM})$. By d 5, all of the fermentors received $100 \%$ of the experimental diets $(20 \mathrm{~g} \mathrm{DM} / \mathrm{d})$ in two equal aliquots at 0900 and 1500 h. Data were collected from d 7 through 9.

The stabilization and dynamics of fermentation were determined by monitoring gas production and the concentration of VFA in the fermentors. Headspace gas and ruminal fluid samples were collected at several predetermined intervals. Gas samples (10 $\mu 1)$ were withdrawn six times daily (before the 0900 and $1500 \mathrm{~h}$-feeding times; and one and two h after feeding times) with the aid of a gas tight syringe (Hamilton Co., Reno, NV). Samples were used to determine $\mathrm{CH}_{4}$ concentration by gas chromatography (CP-3800, Varian, Walnut Creek, CA) using a stainless steel column filled to capacity with Molsieve 5A 45/60 mesh (Supelco Inc.). Ruminal culture $\mathrm{pH}$ was monitored continuously and recorded each time gas 
measurements were collected. Thoroughly mixed ruminal fluid samples $(15 \mathrm{ml})$ were collected daily ( $2 \mathrm{~h}$ after the 0900 feeding time) during the last three days of each experimental period. Five-ml aliquots were used to analyze VFA by gas chromatography (CP-3380, Varian, Walnut Creek, CA) using a fused silica capillary column (Nukol, Supelco Inc., Bellefonte, $\mathrm{PA}$ ) and $\mathrm{NH}_{3}-\mathrm{N}$ was determined according to a colorimetric assay (Beecher and Whitten, 1970). Production of $\mathrm{NH}_{3}-\mathrm{N}$ was calculated as follows: $\mathrm{NH}_{3}-\mathrm{N}, \mathrm{g} / \mathrm{d}=\left(\mathrm{NH}_{3}-\mathrm{N}\right.$ concentration, $\mathrm{mg} / \mathrm{ml} \mathrm{x}$ fermentor volume $\mathrm{x}$ turnover rate of fermentor)/1,000.

Twenty-four h after the 0900 feeding time of the last day of each period, ruminal contents were sampled and kept frozen $\left(-20^{\circ} \mathrm{C}\right)$. Once thawed, ruminal contents were analyzed for $\mathrm{DM}\left(24 \mathrm{~h}\right.$ at $\left.105^{\circ} \mathrm{C}\right)$ and $\mathrm{NDF}$ concentration. In addition, ruminal culture samples $(50 \mathrm{ml})$ were collected and kept frozen $\left(-20^{\circ} \mathrm{C}\right)$. After thawing, the samples were mixed with $25 \mathrm{ml}$ of $0.9 \%(\mathrm{wt} / \mathrm{vol}) \mathrm{NaCl}$ and $1.5 \mathrm{ml}$ of $30 \%$ (vol/vol) formaldehyde and divided into two aliquots. Both aliquots were used to isolate microbial cells by differential centrifugation (a first centrifugation at $1,074 \times \mathrm{g}$ for 5 min to precipitate particles and a second centrifugation at $47,800 \mathrm{x}$ g for $20 \mathrm{~min}$ to sediment the bacteria). The microbial pellet obtained was dried for $4 \mathrm{~h}$ at $50^{\circ} \mathrm{C}$ and analyzed for microbial $\mathrm{N}$ concentration.

\section{Diet Characterization}

Total mixed ration samples were taken once a week, stored at $-20^{\circ} \mathrm{C}$, and subsequently freeze-dried. Total mixed ration biweekly composites from weeks 5-6 and 7-8 were weighed and combined into one sample, and ground to pass a $5 \mathrm{~mm}$ screen in a Wiley Mill (Thomas Scientific, Swedesboro, NJ) before being added to the fermentors. Total mixed ration particle size $(>1.7 \mathrm{~mm}=13 \% ;<1.7$ but $>0.5 \mathrm{~mm}=48 \% ;<0.5 \mathrm{~mm}=39 \%)$ was determined after dry sieving freeze-dried TMR samples of approximately $15 \mathrm{~g}$ DM each 
(USA Standard Testing Sieve, Fisher Scientific Co.). Mean and median particle sizes were calculated according to (Fisher et al., 1988) and were 0.85 and $0.66 \mathrm{~mm}$, respectively. The ingredient composition of the TMR offered to the continuous culture vessels is presented in Table 1.

Weekly composites (weeks 4 through 8 ) of hand-plucked pasture samples that were collected in a companion experiment (Chapter 3, experiment 2, spring of 2005) were added to the fermentors. Hand-plucked pasture samples were harvested twice a week, and weekly composites were stored at $-20^{\circ} \mathrm{C}$, and subsequently freeze-dried. Pasture weekly composites from weeks 4 through 8 (weeks that represented the experimental period in experiment 2) were weighed and combined into one sample, and chopped with a kitchen blender before being added to the fermentors. Particle size $(>1.7 \mathrm{~mm}=12 \%$; $<1.7$ but $>0.5 \mathrm{~mm}=59 \%$; $<$ $0.5 \mathrm{~mm}=29 \%$ ) was determined following the same procedure used for TMR samples. Mean and median particle sizes of the forage added to the fermentors were 0.98 and $0.82 \mathrm{~mm}$, respectively. Chemical analysis and NIR spectroscopy (including calibration and validation statistics) of the forage and TMR samples have been described earlier in a companion study (Chapter 3). Chemical composition of the TMR and forage added to the continuous culture vessels are presented in Table 2 .

\section{Ruminal Fermentation Calculations}

Total substrate added to the vessels was partitioned into the amount of substrate fermented to VFA, gas $\left(\mathrm{CH}_{4}\right.$ plus $\left.\mathrm{CO}_{2}\right)$, and microbial biomass. Carbon dioxide was further characterized as fermentative $\mathrm{CO}_{2}$ (from the fermentation of hexoses) and buffering $\mathrm{CO}_{2}$ (resulting from the bicarbonate-based buffer entering the continuous culture system) (Beuvink and Spoelstra, 1992; Blummel et al., 1997). Fermentative $\mathrm{CO}_{2}$ is considered a more 
direct source of $\mathrm{CO}_{2}$ which is an end product of glucose fermentation by various pathways that also yield VFA and ATP (Van Soest, 1994). The use of bicarbonate-based buffering solutions in continuous cultures releases $\mathrm{CO}_{2}$ into the gas headspace as VFA enter the medium (Beuvink and Spoelstra, 1992) and is considered an indirect source of $\mathrm{CO}_{2}$. The amount of substrate fermented to $\mathrm{CO}_{2}$, VFA, and methane was calculated based on the $\mathrm{CO}_{2}$ released from fermentation and buffer addition, the moles of individual VFA produced, and daily methane output, respectively (Wolin, 1960; Van Soest, 1994; Blummel et al., 1997). Daily methane output was calculated as reported by Eun et al. (2004a) using the following equation for data from the same fermentors: Daily methane output, $\mathrm{mmol} / \mathrm{d}=$ methane concentration in vessel headspace $(\mathrm{mmol} / \mathrm{ml}) \times$ daily $\mathrm{CO}_{2}$ gas flow $(20 \mathrm{ml} / \mathrm{min} \times 60 \mathrm{~min} \times 24$ h).

In addition to estimating the amount of substrate fermented to $\mathrm{CO}_{2}$, VFA, and methane, daily microbial $\mathrm{N}$ flow (g DM) was calculated directly from the total microbial DM present in culture contents measured by isolation of microbial pellets $24 \mathrm{~h}$ after the 0900 feeding time of the last day of each run. Microbial $\mathrm{N}$ flow was calculated using the following equation: Microbial $\mathrm{N}$ flow, $\mathrm{g} / \mathrm{d}=$ microbial $\mathrm{DM}$ flow $(\mathrm{g} / \mathrm{d}) \times$ (microbial $\mathrm{N} \% / 100)$. Calculations of microbial DM flow were based on a solids dilution rate of $4.6 \% / \mathrm{h}$ (Eun et al., 2004a). The efficiency of microbial synthesis was calculated based on daily microbial DM flow and reported both in terms of OM added and OM truly fermented (substrate partitioned into the sum of VFA and gas production, and microbial synthesis).

\section{Experimental Design and Statistical Analysis}

Each vessel was randomly assigned to one of four dietary treatments that varied in TMR and forage proportions. The four dietary treatments assigned at random to the different 
vessels were tested in a randomized complete block design (Steel et al., 1997) with 4 independent 9- $\mathrm{d}$ runs and analyzed using the PROC MIXED procedure of SAS, version 9.1.3 (2002). The model included the fixed effects of dietary treatment using run as a random term, in addition to a random residual error term. Within each run, the experiment included $6 \mathrm{~d}$ for adaptation representing more than 14 volume turnovers and in excess of what is required to achieve steady state conditions (Isaacson et al., 1975). This was followed by $3 \mathrm{~d}$ for data collection. Each period included the use of 4 fermentors that were inoculated simultaneously with ruminal contents extracted from the same cow. Least squares means \pm SEM are reported for all data. When dietary treatments differed significantly, means were separated with the PDIFF option in SAS (2002).

\section{RESULTS AND DISCUSSION}

\section{Diet Characteristics}

Because of the substitution of TMR with increasing amounts of pasture allocated to the grazing animal, diets added to the fermentors exhibited forage/concentrate $(\mathbf{F}: \mathbf{C})$ ratios that ranged from 40:60 (100T) to 67:33 (55T) (Table 3). Final diet OM, NDF, ADF, and CP concentrations were relatively similar for all dietary treatments, and averaged 93.1, 44.4, 22.0, and 15.4\% (DM basis). The TMR was designed to meet or exceed current nutrient recommendations for a Holstein cow producing $35 \mathrm{~kg}$ of milk, and was originally formulated to provide approximately $16 \%$ CP $(38.8 \%$ RUP, $6.1 \%$ EE; NRC 2001). Consequently, lowering the amounts of TMR added decreased intake of RUP and EE. The TMR added contained approximately $27 \%$ corn silage and $13 \%$ alfalfa silage (DM basis, Table 1). Annual ryegrass IVTDMD averaged $93.1 \%$, substantially greater than the TMR IVTDMD (79.6\%; Table 2). Although unexpectedly high, our annual ryegrass IVTDMD results are in 
agreement with findings reported by Cammell et al. (1983) and Corbett and Pickering (1983) for perennial ryegrass and Reed canarygrass averaging 94 and 96\% IVTOMD, respectively.

Compared with nutritive values typically reported for high quality cool-season forages (18 to $24 \% \mathrm{DM}, 18$ to $25 \% \mathrm{CP}, 40$ to $50 \% \mathrm{NDF}$, and $\mathrm{NE}_{1}$ concentrations ranging from 1.53 to $1.67 \mathrm{Mcal} / \mathrm{kg} \mathrm{DM}$; Cherney and Allen, 1995) our pasture was lower in CP and greater in energy concentration. The low CP values reported in our study are primarily due to the lack of supplemental $\mathrm{N}$ added to the soil during the spring grazing season and a noticeable decrease in the leaf/stem ratio as the season progressed. The leaf/stem ratio declined from 1.35 (late March, 2005) to 0.14 (mid May, 2005). It needs to be noted that the NE value of annual ryegrass reported in our study was obtained using the Pennsylvania State University equation based on ADF concentration (Undersander et al., 1993), and is considerably greater than the value predicted by NRC (2001) for intensively managed coolseason grass pastures at high levels of intake (1.45 Mcal $/ \mathrm{kg} \mathrm{DM})$.

Quantification of different $\mathrm{CP}$ fractions has been addressed for a number of feedstuffs, but information on CP fractions in fresh forages is limited (Elizalde et al., 1999; Klopfenstein, 1996). Although final diets added to the fermentors were not quantified, CP present in the TMR and pasture was quantified further into NPN (fraction A), soluble protein $\left(B_{1}\right)$, insoluble protein that was soluble in neutral detergent $\left(B_{2}\right)$, protein that was insoluble in neutral detergent but soluble in acid detergent (NDIP, fraction $\mathrm{B}_{3}$ ) and protein that was insoluble in acid detergent (ADIP, fraction C) (Table 2). Fractions $\mathrm{B}_{1}, \mathrm{~B}_{2}$, and $\mathrm{B}_{3}$ are true protein fractions with decreasing solubility (Van Soest, 1994), and ADIP is an estimate of indigestible protein (Klopfenstein, 1996). Based on these guidelines, NPN was greater for the TMR compared to forage (26.4 vs. $11.0 \%$ of $\mathrm{CP}$, respectively), but the sum of fractions A 
and $\mathrm{B}_{1}$, constituents that are rapidly degraded in the rumen, was greater for the forage (48.9 vs. $29.4 \%$ of $\mathrm{CP}$ ). Fractions $\mathrm{A}$ and $\mathrm{B}_{1}$ are intensively degraded in the rumen, provided available carbohydrate is not limiting for microbial growth, and used for microbial protein synthesis (Tamminga, 1986; Van Soest, 1994).

\section{Fermentation Assessment}

\section{Volatile Fatty Acids}

Feeding the greatest amount of forage resulted in an increase $(P=0.08)$ in VFA concentration ( $64.5 \mathrm{mM}$ for $55 \mathrm{~T}$ vs. $51.1 \mathrm{mM}$ for $100 \mathrm{~T}$; Table 4). Increasing the amount of forage added to the fermentors altered the molar proportions and daily production of VFA. Molar proportion of acetate was greatest $(P<0.05)$ for $100 \mathrm{~T}(47.9 \%)$ and lowest for $55 \mathrm{~T}$ and $70 \mathrm{~T}($ mean $=40.3 \%)$. Similarly, the molar proportion of propionate was greatest $(P<0.05)$ for the dietary treatments that had the greatest amount of TMR ( $85 \mathrm{~T}$ and 100T averaged 25.9 $\%$ vs. $20.3 \%$ for $55 \mathrm{~T}$ and $70 \mathrm{~T}$ ). Conversely, the molar proportion of butyrate and valerate were greatest $(P<0.05)$ for 55T and 70T $(27.2 \%$ butyrate and $7.4 \%$ valerate $)$ compared with $100 \mathrm{~T}$ (16.1 and 2.6\%, respectively). The molar proportions of the branch-chain fatty acids (BCFA) isovalerate and isobutyrate were greatest $(P<0.05)$ for $85 \mathrm{~T}$ and $100 \mathrm{~T}$, averaging 5.1 and $1.0 \%$ of VFA, respectively, compared to the dietary treatment that included the greatest amount of forage (55T; 3.7 and $0.8 \%$ of VFA, respectively).

Daily production of acetate was lowest $(P=0.08)$ for $70 \mathrm{~T}$ and greatest for $55 \mathrm{~T}$ and 85T. Daily propionate production was greatest $(P<0.05)$ for treatments 55T, 85T, and $100 \mathrm{~T}$ averaging $22.8 \mathrm{mmol}$, compared with $70 \mathrm{~T}(18.1 \mathrm{mmol})$. Daily production of butyrate and valerate increased $(P<0.05)$ with increasing amounts of forage in the diets. Although the molar proportion of the BCFA was affected, the daily production of the BCFA isovalerate 
and isobutyrate remained unaffected across dietary treatments. In accordance with VFA concentrations, treatment 55T tended $(P=0.08)$ to yield the greatest amounts of total VFA $(108.0 \mathrm{mmol} / \mathrm{d})$, followed by treatment $85 \mathrm{~T}(98.7 \mathrm{mmol} / \mathrm{d})$.

Increasing the $\mathrm{F}: \mathrm{C}$ ratio by increasing the amounts of forage fed increased $(P<0.05)$ the acetate/propionate ratio (A:P), which is consistent with previous in vivo (Siciliano-Jones and Murphy, 1989; Bargo et al., 2002b) and in vitro (Bach et al., 1999; Bargo et al., 2003; Vibart et al., 2007) findings. The increase in the A:P ratio was due to changes in daily production of both acetate and propionate. The effect of $\mathrm{F}: \mathrm{C}$ on total VFA production and fermentation profiles in other studies has been variable. Compared to our findings, previous in vitro studies using the same dual-flow continuous culture system reported lower total VFA production (Eun et al., 2004a, 2004b, Vibart et al., 2007). The greater VFA production in our study was associated with feeding greater amounts daily (20.0 g DM vs. 14.0, 12.9, and 15.0 g DM reported in Eun et al., 2004a, 2004b, and Vibart et al., 2007, respectively) of diets that were presumably of greater nutritive value. Also, Eun et al. (2004b) reported no effect of F:C on total VFA production (diets tested were 70:30, 50:50, and 30:70 F:C of diets that comprised alfalfa pellets and a ground corn-based mix as the forage and concentrate portions of the diet, respectively) and averaged $58.0 \mathrm{mmol} / \mathrm{d}$ across three fractional dilution rates tested $(3.2,6.3$, and $12.5 \% / \mathrm{h})$. Similarly, total VFA production from continuous cultures fed tall fescue (Festuca arundinacea L.) diets that remained unsupplemented or were supplemented with increasing amounts of ground corn $(15,30$, or $45 \%$ of the diet, DM basis) was similar across treatments and averaged $58.8 \mathrm{mmol} / \mathrm{d}$ (Vibart et al., 2007). Conversely, total VFA production from continuous cultures fed gamagrass (Tripsacum dactyloides L.) silage supplemented with low, medium, and high levels of a concentrate mix (a mix of 
ground corn and soybean meal) was greatest for the greatest inclusion of supplemental concentrate (Eun et al., 2004a). Total VFA production ranged from $47.2 \mathrm{mmol} / \mathrm{d}$ for gamagrass silage that remained unsupplemented to $55.1 \mathrm{mmol} / \mathrm{d}$ for the greatest amount of concentrate offered. However, the F:C ratio of the dietary treatment that received the greatest amount of concentrate in the study by Eun et al. (2004a) was greater than the F:C ratio of the TMR used in our study (40:60). It is important to note that the forage components of the diets used by Eun et al. (2004a, 2004b) were conserved forages, and only Vibart et al. (2007) fed fresh forages.

Bargo et al. (2003) reported increased total VFA concentrations $(61.7,81.8$, and 96.1 $\mathrm{mmol} / \mathrm{L}$ ) from pasture-only diets with increasing amounts of forage added to continuous cultures $(55,65$, and $75 \mathrm{~g} \mathrm{DM} / \mathrm{d}$, respectively) but VFA concentrations were lower compared to a forage plus concentrate diet $(113.2 \mathrm{mmol} / \mathrm{L}$ from $45 \mathrm{~g}$ of pasture DM plus $30 \mathrm{~g}$ concentrate DM). Kolver et al. (1998) reported no differences in acetate and propionate concentration between pasture only and pasture plus starch diets in continuous culture. Diets were formulated using additions of starch to contain 12.8, 19.6, 26.3, and 33\% total NSC (Kolver et al., 1998).

Greater molar proportions (g/100 g VFA) and daily production (mmol/d) of butyrate in the cultures receiving the greatest amounts of forage (Table 4) could be associated with greater concentrations of protozoa in these cultures (Eadie and Mann, 1970; Ushida et al., 1986; Jaakkola and Huhtanen, 1993). Early observations by Eadie and Mann (1970) showed that protozoa populations can have noticeable effects on VFA ratios, namely ciliated protozoa associated with butyrate production. Ushida et al. (1986) showed that faunated ruminal contents of sheep had greater molar concentrations of butyrate than did defaunated 
cultures. In addition to the gentle stirring of the ruminal contents (set at a speed of approximately $10 \mathrm{rpm}$ ), the natural stratification provided by the dual-flow continuous culture system used in our study has allowed for the continued existence of protozoal populations over extended periods of time (Teather and Sauer, 1988; Eun et al., 2004b).

Compared with the dietary treatment with the greatest amount of forage (55T) where all three major VFA (acetate, propionate, and butyrate) yields were greatest, the diets that had the greatest amounts of TMR (100T and 85T) exhibited the lowest butyrate production (Table 4). Consequently, ratios of (acetate plus butyrate)/propionate $[(\mathbf{A}+\mathbf{B}): \mathbf{P}]$ declined with increasing amounts of TMR added, and ranged from 3.49 (55T) to 2.35 (100T). A clear association between changes in the ruminal VFA pattern and reduction in milk fat concentration has been reported for a wide range of diets. Sutton et al. (1988) estimated that up to $80 \%$ of the variation in milk fat concentration could be accounted for by variations in molar proportions of VFA in the rumen, and reported that lipogenic-to-glucogenic VFA ratios $[(\mathrm{A}+\mathrm{B}): \mathrm{P}]$ were probably more suitable predictors of milk fat depression than A:P ratios. Acetate and butyrate are each positively correlated with milk fat concentration whereas propionate is negatively correlated with milk fat concentration. The lowest $(\mathrm{A}+\mathrm{B}): \mathrm{P}$ for the all-TMR diet is consistent with the lowest milk fat concentration from cows fed 100T reported in a companion study (Chapter 3, spring of 2005).

Previous studies with dairy cows on pasture and supplemented with corn-based concentrates reported total VFA concentrations that ranged from approximately 95 to 145 mmol/L (Dann et al., 1999; Reis et al., 2000b, 2001; Bargo et al., 2002b). Although a number of U.S. studies have previously compared animal performance of high-producing dairy cows on TMR vs. pasture-only diets (Kolver and Muller, 1998; Tucker et al., 2001), TMR vs. 
pasture plus concentrate (White et al., 2002; Fontaneli et al., 2005), and TMR vs. TMR plus pasture (Soriano et al., 2001; Bargo et al., 2002a, 2002b), only Bargo et al. (2002b) evaluated rumen digestion variables. Total VFA concentration did not differ among cows that were fed either a predominantly smooth bromegrass pasture supplemented with $8.8 \mathrm{~kg} \mathrm{DM}$ of a cornbased concentrate (60:40 F:C), pasture plus a corn-silage based TMR (60:40 F:C), or TMR (52:48 F:C) (Bargo et al., 2002b). Total VFA concentration averaged $137 \mathrm{mmol} / \mathrm{L}$, maintaining similar VFA molar proportions for the three main VFA (averaging 63.1, 20.6, and $12.0 \mathrm{~mol} / 100 \mathrm{~mol}$ for acetate, propionate, and butyrate, respectively) and acetate/propionate ratios (3.11) (Bargo et al., 2002b).

Culture pH, Ammonia N and Methane Production

Feeding the greatest amount of forage increased $(P=0.06)$ ruminal culture $\mathrm{pH}$ (Table 5). Compared with 55T (pH 5.8), continuous culture $\mathrm{pH}$ from diets $70 \mathrm{~T}$ (5.65) and 100T (5.68) were reduced. Ruminal $\mathrm{pH}$ values reported in this study were lower compared to other continuous culture studies where fresh forages were fed (Bach et al., 1999; Bargo et al., 2003; Vibart et al., 2007). Ruminal pH from a pasture-only diet (50\% orchardgrass, $50 \%$ legumes) added to continuous cultures was 6.1, and decreased with the inclusion of either cracked corn, beet pulp with molasses, or soybean hulls to 6.03 (Bach et al., 1999). Bargo et al. (2003) found that as the amounts of pasture offered to continuous cultures increased from 55 to $75 \mathrm{~g} / \mathrm{d}$, ruminal $\mathrm{pH}$ was reduced linearly from 6.98 to 6.55 , and was reduced further to 5.97 by replacing $30 \mathrm{~g}$ of the pasture with a corn-based concentrate. Ruminal culture $\mathrm{pH}$ decreased linearly when increasing grain supplementation levels were added to fresh tall fescue in continuous culture (Vibart et al., 2007). Culture pH values averaged 6.2 for pasture-only diets and 6.0 for the greatest supplementation level (45\% grain). The type of 
buffer (Bach et al., 1999; Bargo et al., 2003) and the nutritive value of the forages used (Vibart et al., 2007) may partially explain the lower $\mathrm{pH}$ values obtained in our study.

Ruminal $\mathrm{pH}$ values reported in our study are in agreement with in vivo data from cows fed high quality, pasture-based diets (Mackle et al., 1996; Reis et al., 2001; Bargo et al., 2002b). Ruminal pH of cows fed pasture plus concentrate, pasture plus TMR, or TMR did not differ across dietary treatments and averaged 5.87 (Bargo et al., 2002b), similar to findings reported earlier for high-producing dairy cows consuming fresh grass-legume forage supplemented daily with $10 \mathrm{~kg}$ of corn grain $(\mathrm{pH}=5.79$; Reis et al., 2001). When fermentable carbohydrates are added to forage diets (i.e. increasing the amounts of TMR offered in our study) ruminal $\mathrm{pH}$ is typically lowered, which is consistent with the lowest $\mathrm{pH}$ reported for 100T. Ruminal $\mathrm{pH}$ of high-producing dairy cows fed diets with $50 \%$ concentrates is often 5.7 (Satter et al., 1999). Ruminal pH from diets that include highquality forages is often below values recommended to optimize digestion (de Veth and Kolver, 2001). Steady-state models of digestion, such as the CNCPS (Pitt et al., 1996), set a $\mathrm{pH}$ threshold value of 6.2 below which growth of fiber-degrading microbes is impaired, resulting in depressed fiber and OM digestibility. However, ruminal $\mathrm{pH}$ may be as low as 5.8 before microbial protein synthesis and fiber digestibility are impaired for high quality pasture diets (de Veth and Kolver, 2001). The optimal pH for fiber digestion identified by in vitro studies (Hoover and Stokes, 1991) is often greater than the mean daily ruminal $\mathrm{pH}$ observed in dairy cows consuming high-quality pasture. To elucidate the association between pasture digestibility and ruminal $\mathrm{pH}$, Mould et al. (1984) reported that forages with high digestibility are less sensitive to reductions in ruminal $\mathrm{pH}$ than are forages of low digestibility. Previously, Terry et al. (1969) reported that a $24-\mathrm{h}$ incubation reduced ruminal $\mathrm{pH}$ from 6.8 
to 5.5 and reduced IVDMD of mature ryegrass by approximately 15 percentage units, whereas immature ryegrass was only reduced by 9 percentage units.

Ruminal $\mathrm{NH}_{3}-\mathrm{N}$ concentration and production remained unaffected across dietary treatments and averaged $23.1 \mathrm{mg} / \mathrm{dl}$ and $0.39 \mathrm{~g} / \mathrm{d}$, respectively (Table 5). In theory, these findings would have been consistent with similar CP intakes for all treatments (CP intakes only ranged from 3.0 to $3.2 \mathrm{~g} / \mathrm{d}$ ), but simultaneously, equal amounts of rumen-degradable protein would have been required. Because increasing the amount of forage added resulted in an increase $(P<0.05)$ in daily microbial biomass yield and microbial DM flow (Table 6), lower ruminal $\mathrm{NH}_{3}-\mathrm{N}$ concentrations would have been expected for treatments $55 \mathrm{~T}$ and $70 \mathrm{~T}$ due to increased $\mathrm{N}$ capture. This did not occur. A possible explanation for what we think occurred is that by increasing the amount of forage there was an increase in the proportion of rapidly degradable $\mathrm{CP}$ (fractions $\mathrm{A}$ and $\mathrm{B}_{1}$ ) which lowered the proportion of rumenundegradable protein. The accumulation of $\mathrm{NH}_{3}-\mathrm{N}$ in the vessel fluid depends on the extent of CP degradation and the rate of $\mathrm{N}$ utilization by ruminal bacteria (Lana et al., 1998). The balance between these two opposing events resulted in similar $\mathrm{NH}_{3}-\mathrm{N}$ concentrations for all diets.

Concentrations of $\mathrm{NH}_{3}-\mathrm{N}$ were greater than the minimum required to ensure maximum microbial growth (5 mg/dl; Satter and Slyter, 1974), and were greater than other continuous culture studies. Bach et al. (1999) reported $\mathrm{NH}_{3}-\mathrm{N}$ concentrations that ranged from $10.3 \mathrm{mg} / \mathrm{dl}$ for a pasture-only diet to $2.1 \mathrm{mg} / \mathrm{dl}$ for pasture plus cracked corn $(55: 45$ $\mathrm{F}: \mathrm{C})$. The effectiveness of corn in promoting $\mathrm{NH}_{3}-\mathrm{N}$ uptake by ruminal microorganisms by providing rapidly-fermented energy in the form of starch (de Visser et al., 1991), the low CP degradation reported, and the loss of protozoa in the continuous culture system used, may 
have contributed to the lower values reported by Bach et al. (1999) compared with our findings. Holden et al. (1994) reported greater $\mathrm{NH}_{3}-\mathrm{N}$ concentrations in faunated ruminal cultures compared to defaunated ones, demonstrating that ruminal protozoa are active in producing $\mathrm{NH}_{3}-\mathrm{N}$. As mentioned previously, the dual-flow continuous culture system used in our study allowed for the continued existence of protozoal populations. In agreement with our findings, Bargo et al. (2003) reported $\mathrm{NH}_{3}-\mathrm{N}$ concentrations that ranged from $23.4 \mathrm{mg} / \mathrm{dl}$ for the lowest amount of forage fed $(55 \mathrm{~g} \mathrm{DM} / \mathrm{d})$ to $27.5 \mathrm{mg} / \mathrm{dl}$ for the medium amount of forage fed $(65 \mathrm{~g} \mathrm{DM} / \mathrm{d})$ to continuous cultures.

Methane production was greatest $(P<0.05)$ for the all-TMR diet $(42.5 \mathrm{mmol} / \mathrm{d})$ and lowest for $70 \mathrm{~T}(16.6 \mathrm{mmol} / \mathrm{d})$ (Table 5). The addition of concentrate to forage-based diets often lowers methane production (Eun et al., 2004b). Also, the decrease in methane production in continuous cultures receiving a greater proportion of concentrate has consistently shown a shift in reducing equivalents toward propionate synthesis (Eun et al., 2004b). However, these effects were not observed in our study, and the effect of F:C on methane production in other studies has been inconsistent. Eun et al. (2004a) and Vibart et al. (2007) reported quadratic responses in methane production to corn grain supplementation in continuous cultures fed gamagrass silage and tall fescue. In agreement with our findings, methane production was numerically greatest for the greatest level of grain supplementation (20.6 mmol/d for a 30:70 F:C diet) followed by an unsupplemented gamagrass silage diet and gamagrass that had the lowest level of supplementation $(19.6 \mathrm{mmol} / \mathrm{d}$ and $19.2 \mathrm{mmol} / \mathrm{d}$, for respectively). The later diet had a F:C of 70:30 (Eun et al., 2004a). Consistent with our findings, the studies mentioned above suggest that methane production did not respond linearly to substrate fermentation. 
In a similar fashion to $\mathrm{pH}$ patterns, feeding the greatest amount of forage numerically but not significantly $(P=0.11)$ increased total gas production (Table 5$)$. Because total gas production was calculated as the sum of fermentative $\mathrm{CH}_{4}$ (measured), fermentative $\mathrm{CO}_{2}$ (from A, P, and B production, $\mathrm{mmol} / \mathrm{d}$ ), and buffering $\mathrm{CO}_{2}$ (from total VFA production, mmol/d) (Wolin, 1960; Beuvink and Spoelstra, 1992), the pattern observed for gas production is consistent with the one observed for total VFA production reported in Table 4. Substrate Partition, Microbial Biomass and Microbial Efficiency

Ruminal fermentation, a term to express ruminal DM digestibility, was defined by the anaerobic decomposition of substrates by microorganisms and evaluated according to the production of end products (Groot et al., 1998) such as VFA and gas production (apparent fermentability) plus microbial biomass (true fermentability) (Table 6). Consistent with findings reported earlier by de Veth and Kolver $(2001)$, reduced $(P<0.05)$ apparent and true OM fermentability was reported for the treatments that exhibited the lowest $\mathrm{pH}$ values $(5.65$ and 5.68 for dietary treatments $70 \mathrm{~T}$ and $100 \mathrm{~T}$, respectively). Substrate partition leading to fermentability, however, was different for both treatments: 70T exhibited the lowest $(P<$ 0.05) gas production $\left(\mathrm{CO}_{2}\right.$ plus $\left.\mathrm{CH}_{4}\right)$ whereas $100 \mathrm{~T}$ exhibited the lowest $(P<0.05)$ microbial biomass synthesis, with $100 \mathrm{~T}$ as intermediate in terms of apparent fermentability. In addition to gas production and microbial biomass, substrate partitioning towards VFA production was lowest for $100 \mathrm{~T}(5.4 \mathrm{~g} / \mathrm{d})$ followed by $70 \mathrm{~T}(5.5 \mathrm{~g} / \mathrm{d})$. Other continuous culture studies that used high-quality forage have reported similar ruminal apparent and true DM and OM digestibilities. In general agreement with our findings, Bargo et al. (2003) reported apparent digestibilities of DM and $\mathrm{OM}$ of 52.2 and $65.5 \%$, respectively, for a diet containing $60 \%$ pasture and $40 \%$ concentrate (ruminal culture $\mathrm{pH}$ averaged 5.97). Previously, and similar to 
what occurred in our study, de Veth and Kolver (2001) reported ruminal apparent DM and OM digestibilities of 56.4 and $58.7 \%$, respectively, for a ryegrass-only diet fermented in continuous culture at a $\mathrm{pH}$ that was artificially maintained at 6.6. Ruminal apparent DM and OM digestibilities declined to 44.7 and $48.1 \%$, respectively, for the same diet when the ruminal culture $\mathrm{pH}$ was lowered to 5.4 (de Veth and Kolver, 2001). Also, constant low pH (5.7) resulted in reduced cellulolytic activity and protein digestion of continuous cultures fed a $60 \%$ alfalfa hay and $40 \%$ concentrate diet (Calsamiglia et al., 2002). Apparent and true DM fermentabilities reported by Calsamiglia et al. (2002) were 46.3 vs. $39.2 \%$, and 60.5 vs. $57.9 \%$ for cultures that were kept at $\mathrm{pH}$ levels of 6.4 vs. 5.7, respectively. In a similar fashion, NDF and $\mathrm{CP}$ fermentabilities were 53.8 vs. $34.3 \%$, and 55.6 vs. $41.6 \%$ at $\mathrm{pH}$ levels of 6.4 vs. 5.7, respectively (Calsamiglia et al., 2002).

Bacterial $\mathrm{N}$ concentration, expressed as a percentage of bacterial DM, was greatest for $(P=0.06)$ treatments $70 \mathrm{~T}$ and $85 \mathrm{~T}$, intermediate for 55T, and lowest for 100T (Table 6). Consistent with our findings, several researchers also reported decreased $\mathrm{N}$ concentrations in ruminal bacteria from continuous cultures (Bach et al., 1999) and from animals (Cecava et al., 1988; Olubobokun et al., 1988) receiving rapidly fermentable diets compared to those receiving a more slowly fermentable diet.

As mentioned previously, increasing the amount of forage added to continuous cultures resulted in an increase $(P<0.05)$ in daily microbial biomass yield $(\mathrm{g} / \mathrm{d})$ and microbial DM flow (g/d) (Table 6). Daily microbial yield from diet 55T was 2.3-fold greater than $100 \mathrm{~T}$ (1.98 vs. $0.85 \mathrm{~g} / \mathrm{d}$, respectively) and 1.6-fold greater than $85 \mathrm{~T}(1.98 \mathrm{vs.} 1.23 \mathrm{~g} / \mathrm{d}$, respectively). Previous continuous culture studies using high-quality forages that compared pasture-only diets with supplemented diets have reported daily bacterial $\mathrm{N}$ flows to be 
similar (Kolver et al., 1998; Bach et al., 1999) or greater for pasture-only diets (Bargo et al., 2003). Four levels of inclusion of starch $(0,5.9,11.7$, and $17.5 \mathrm{~g}$ starch for a total of $75 \mathrm{~g}$ $\mathrm{DM}$ fed) had no effect on ruminal bacterial $\mathrm{N}$ flow and averaged $1.1 \mathrm{~g} / \mathrm{d}$ bacterial $\mathrm{N}$ (Kolver et al., 1998). In agreement with our findings, Bargo et al., 2003 reported greater daily bacterial $\mathrm{N}$ flow for a pasture-only diet $(1.53 \mathrm{~g} / \mathrm{d})$ compared to pasture plus a corn-based concentrate $(1.25 \mathrm{~g} / \mathrm{d})$. The greater bacterial $\mathrm{N}$ flow values reported by Kolver et al. (1998) and Bargo et al. (2003) compared with the values reported in our study are associated with greater amounts of $\mathrm{DM}$ fed of diets that were greater in $\mathrm{CP}$ concentration: pastures in Kolver et al. (1998) and Bargo et al. (2003) were 24.4 and $25.3 \% \mathrm{CP}$, respectively, vs. $13.8 \% \mathrm{CP}$ in our study. In vivo studies support the association between intake and bacterial $\mathrm{N}$ flow levels. A significant positive relationship was established between OM intake and flow of bacterial $\mathrm{N}$ based on a database from 36 experiments with duodenally cannulated cows (Clark et al., 1992). In our study, increasing the amount of TMR fed also increased the amounts of RUP fed. Compared to 70T, enhanced microbial yield (and consequentially enhanced microbial flow to the lower tract) and ruminal DM digestibility in $55 \mathrm{~T}$ is consistent with a numerically greater milk production and gross feed efficiency supported by this diet $(32.7 \mathrm{vs.} 31.9 \mathrm{~kg}$ of milk and 1.62 vs. 1.54 FCM per kg of DMI for diets $55 \mathrm{~T}$ vs. $70 \mathrm{~T}$, respectively; Chapter 3, experiment 2).

Although microbial DM per $\mathrm{kg}$ OM fed decreased $(P<0.05)$ with increasing proportions of TMR in the diets, microbial efficiency (microbial DM per kg OM truly fermented, g/d) was greatest $(P<0.05)$ for the dietary treatments that included greater proportions of forage (55T and $70 \mathrm{~T}$ ) compared to those with greater proportions of TMR (85T and 100T) (Table 6). Greater microbial efficiencies are often associated with greater 
microbial yields, similar to what occurred with 55T. However, other occasions do not necessarily reflect microbial synthesis as much as OM truly fermented in the rumen (Bach et al., 1999), as is the case for diet 70T (lower microbial yields and lower true OM fermentability compared to 55T). By replacing high quality pasture with different energy supplements (in a 1:1 substitution manner to account for equivalent DMI), previous in vivo (Garcia et al., 2000) and continuous culture studies (Kolver et al., 1998; Bach et al., 1999; Bargo et al., 2003) have reported that microbial $\mathrm{N}$ synthesis was not enhanced and that the beneficial effect of lowering ruminal $\mathrm{NH}_{3}-\mathrm{N}$ concentration was more associated with lower $\mathrm{N}$ intakes than an improved capture of $\mathrm{NH}_{3}-\mathrm{N}$ by microbial populations. Using the same continuous culture system, Eun et al. (2004a) reported microbial efficiencies (g of microbial $\mathrm{N} / \mathrm{kg}$ of OM apparently fermented) that ranged from 5.8 for unsupplemented gamagrass silage, to 6.4 for gamagrass silage supplemented at the greatest level tested $(4.0 \mathrm{~g}$ of gamagrass silage plus $9.6 \mathrm{~g}$ of concentrate). In terms of microbial $\mathrm{N}$ efficiency (g microbial $\mathrm{N} / \mathrm{kg}$ OM truly fermented) values reported in our study are slightly greater, ranging from $11.5(\operatorname{diet} 70 \mathrm{~T})$ to $5.5(\operatorname{diet} 100 \mathrm{~T})$.

Although microbial efficiencies reported in our study are lower than other continuous culture studies using high-quality pasture (Bach et al., 1999; Bargo et al., 2003), our data is in general agreement with that summarized by Van Soest (1994). High concentrate diets exhibited lower efficiencies compared to supplemented forage diets (values ranged from 13 to $26 \mathrm{~g}$ microbial $\mathrm{N} / \mathrm{kg}$ OM truly digested for high concentrate diets, mean $=21$; to 17 to $47 \mathrm{~g}$ microbial $\mathrm{N} / \mathrm{kg}$ OM truly digested for supplemented forage diets, mean $=28$ ). The greater microbial efficiency in forage-based diets was attributed to lower costs of maintenance of fiber- vs. starch-digesting bacteria (Russell et al., 1992, cited by Van Soest, 1994). In our 
study, healthy protozoal populations, presumably in greater quantities in continuous cultures that had the greatest amount of pasture (although not quantified), may also have contributed to the differences in microbial efficiencies between treatments with greater pasture (55T and $70 \mathrm{~T})$ and treatments with greater TMR (85T and 100T).

In order to maximize lactation performance, the need to balance supplies of ruminally available energy and $\mathrm{N}$ has been well documented. The efficiency of production in lactating dairy cows is optimal when microbial protein synthesis in the rumen (and flowing to the lower tract) is maximized, but although extensively researched, the level of readily fermentable carbohydrates for optimal microbial growth has been difficult to define (Hoover and Stokes, 1991; Kim et al., 1999). In our study, varying the proportions of forage and TMR fed to continuous cultures had a significant impact on ruminal fermentation, intermediates and end products. Increasing the amount of forage resulted in increased acetate/propionate and (acetate plus butyrate)/propionate ratios, improved $\mathrm{N}$ utilization by ruminal microorganisms, and decreased methane production. Based on total VFA and gas production, ruminal culture $\mathrm{pH}$, and true fermentability, two distinct dietary groups surfaced (55T and $85 \mathrm{~T}$ vs. $70 \mathrm{~T}$ and $100 \mathrm{~T})$.

\section{SUMMARY AND CONCLUSIONS}

Dual flow continuous culture fermentation was conducted to examine ruminal function and characteristics, and post-ruminal potential supply of nutrients underlying the lactation performance obtained from feeding diets that were formulated for two field trials. Diets combined varying amounts of forage representing pasture and TMR. Although ruminal $\mathrm{NH}_{3}-\mathrm{N}$ concentration and daily flow was similar for all diets, increasing the amount of forage resulted in improved $\mathrm{N}$ capture by ruminal microorganisms, in addition to increases of 
acetate/propionate and (acetate plus butyrate)/propionate ratios. Based on total VFA and gas production, ruminal culture $\mathrm{pH}$, and true fermentability, two distinct ruminal fermentation patterns were observed, namely diets $55 \mathrm{~T}$ and $85 \mathrm{~T}$ vs. $70 \mathrm{~T}$ and $100 \mathrm{~T}$. Overall, the testing of diets using continuous culture fermentation was extremely useful in elucidating some of the intricate ruminant physiology associated with lactation performance. 


\section{LITERATURE CITED}

Bach, A., I. K. Yoon, M. D. Stern, H. G. Jung, and H. Chester-Jones. 1999. Effects of type of carbohydrate supplementation to lush pasture on microbial fermentation in continuous culture. J. Dairy Sci. 82:153-160.

Bargo, F., D. H. Rearte, F. J. Santini, and L. D. Muller. 2001. Ruminal digestion by dairy cows grazing winter oats pasture supplemented with different levels and sources of protein. J. Dairy Sci. 84:2260-2272.

Bargo, F., L. D. Muller, J. E. Delahoy, and T. W. Cassidy. 2002a. Performance of high producing dairy cows with three different feeding systems combining pasture and total mixed rations. J. Dairy Sci. 85:2948-2963.

Bargo, F., L. D. Muller, G. A. Varga, J. E. Delahoy, and T. W. Cassidy. 2002b. Ruminal digestion and fermentation of high-producing dairy cows with three different feeding systems combining pasture and total mixed rations. J. Dairy Sci. 85:2964-2973.

Bargo, F., G. A. Varga, L. D. Muller, and E. S. Kolver. 2003. Pasture intake and substitution rate effects on nutrient digestion and nitrogen metabolism during continuous culture fermentation. J. Dairy Sci. 86:1330-1340.

Beecher, G. R., and B. K. Whitten. 1970. Ammonia determination: reagent modification and interfering compounds. Anal. Biochem. 36:243-246.

Beever, D. E., and R. C. Siddons. 1984. Digestion and metabolism in the grazing ruminant. Pages 479-497 in Control of Digestion and Metabolism in Ruminants (Eds. L. P. Milligan, W. L. Grovum, and A. Dobson). Proc. $6^{\text {th }}$ Int. Symp. Ruminant Physiol, Banff, Canada.

Beuvink, J. M. W., and S. F. Spoelstra. 1992. Interactions between substrate, fermentation end-products, buffering systems and gas production upon fermentation of different 
carbohydrates by mixed rumen microorganisms in vitro. Appl. Microbiol. Biotechnol. 37:505-509.

Blummel, M., H. P. S. Makkar, and K. Becker. 1997. In vitro gas production: a technique revisited. J. Anim. Physiol. Anim. Nutr. 77:24-34.

Calsamiglia, S., A. Ferret, and M. Devant. 2002. Effects of $\mathrm{pH}$ and $\mathrm{pH}$ fluctuations on microbial fermentation and nutrient flow from a dual-flow continuous culture system. J. Dairy Sci. 85:574-579.

Cammell, S. B., D. E. Beever, D. J. Thomson, A. R. Austin, H. R. Losada, R. T. Evans, M. C. Spooner, and R. A. Terry. 1983. Energy and protein digestion, supply and utilization on two contrasting forages fed to growing steers. Anim. Prod. 36(Abs.):501.

Cecava, M. J., N. R. Merchen, L. L. Berger, and G. C. Fahey. 1988. Effects of dietary energy level and protein source on site of digestion and duodenal nitrogen and amino acid flows in steers. J. Anim. Sci. 66:961-974.

Cherney, J. H., and V. G. Allen. 1995. Forages in a livestock system. Pages 175-188 in Forages Volume I: An Introduction to Grassland Agriculture (Eds. R. F. Barnes, D. A. Miller, and C. J. Nelson) $5^{\text {th }}$ Edition. Iowa State University Press, Ames, IA.

Clark, J. H., T. H. Klusmeyer, and M. R. Cameron. 1992. Microbial protein synthesis and flows of nitrogen fractions to the duodenum of dairy cows. J. Dairy Sci. 75:2304-2323.

Clark, D. A., J. W. Penno, and P. G. Neil. 1997. Nutritional merits and problems of pasture. Pages 397-418 in Milk Composition, Production and Biotechnology. (Eds. R. A. S. Welch, D. J. W. Burns, S. R. Davis, A. I. Popay, and C. G. Prosser). CAB International, London, UK.

Corbett, J. L., and F. S. Pickering. 1983. Rumen microbial degradation and synthesis of 
protein in grazing sheep. Page 301 in Feed Information and Animal Production (Eds. G. E. Robards and R. G. Packham). Farnham Royal, UK.

Dann, H. M., G. A. Varga, and D. E. Putnam. 1999. Improving energy supply to lategestation and early-postpartum dairy cows. J. Dairy Sci. 82:1765-1778.

de Veth, M. J., and E. S. Kolver. 2001. Digestion of ryegrass pasture in response to change in pH in continuous culture. J. Dairy Sci. 84:1449-1457.

de Visser, H., H. Huisert, and R. S. Ketelaar. 1991. Dried beet pulp, pressed beet pulp and maize silage for concentrates in dairy cow rations. 2. Feed intake, fermentation pattern and ruminal degradation characteristics. Neth. J. Agric. Sci. 39:21-25.

Doyle, P. T., S. A. Francis, and C. R. Stockdale. 2005. Associative effects between feeds when concentrate supplements are fed to grazing dairy cows: a review of likely impacts on metabolizable energy supply. Aust. J. Agric. Res. 56:1315-1329.

Eadie, J. M., and S. O. Mann. 1970. Development of the rumen microbial population: high starch diets and instability. Pages 335-347 in Physiology of Digestion and Metabolism in the Ruminant (Ed. A. T. Phillipson). Oriel Press, Newcastle upon Tyne, UK.

Elizalde, J. C., N. R. Merchen, and D. B. Faulkner. 1999. Fractionation of fiber and crude protein in fresh forages during the spring growth. J. Anim. Sci. 77:476-484.

Eun, J-S., V. Fellner, J. C. Burns, and M. L. Gumpertz M.L. 2004a. Fermentation of eastern gamagrass (Tripsacum dactyloides [L.] L.) by mixed cultures of ruminal microorganisms with or without supplemental corn. J. Anim. Sci. 82:170-178.

Eun, J-S., V. Fellner, and M. L. Gumpertz. 2004b. Methane production by mixed ruminal cultures incubated in dual-flow fermentors. J. Dairy Sci. 87, 112-121.

Fellner, V., F. D. Sauer, and J. K. G. Kramer. 1997. Effect of nigericin, monensin, and 
tetronasin on biohydrogenation in continuous flow-through ruminal fermentors. J. Dairy Sci. 80:921-928.

Fisher, D. S., J. C. Burns, and K. R. Pond. 1988. Estimation of mean and median particle size of ruminant digesta. J. Dairy Sci. 71:518-524.

Fontaneli, R.S., L. E. Sollenberger, R. C. Littell, and C. R. Staples. 2005. Performance of lactating dairy cows managed on pasture-based or in freestall barn-feeding systems. J. Dairy Sci. 88:1264-1276.

Garcia, S. C., F. J. Santini, and J. C. Elizalde. 2000. Sites of digestion and bacterial protein synthesis in dairy heifers fed fresh oats with or without corn or barley grain. J. Dairy Sci. $83: 746-755$.

Groot, J. C. J., B. A. Williams, A. J. Oostdam, H. Boer, and S. Tamminga. 1998. The use of cumulative gas and volatile fatty acid production to predict in vitro fermentation kinetics of Italian ryegrass leaf cell walls and contents at various time intervals. Br. J. Nutr. 79:519-525. Holden, L. A., L. D. Muller, G. A. Varga, and P. J. Hillard. 1994. Ruminal digestion and duodenal nutrient flows in dairy cows consuming grass as pasture, hay, or silage. J. Dairy Sci. 77:3034-3042.

Hoover, W. H., and S. R. Stokes. 1991. Balancing carbohydrates and proteins for optimum rumen microbial yield. J. Dairy Sci. 74:3630-3644.

Isaacson, H. R., F. C. Hinds, M. P. Bryant, and F. N. Owens. 1975. Efficiency of energy utilization by mixed rumen bacteria in continuous culture. J. Dairy Sci. 58:1645-1659.

Jaakkola, S., and P. Huhtanen. 1993. The effects of forage preservation method and proportion of concentrate on nitrogen digestion and ruminal fermentation in cattle. Grass Forage Sci. 48:146-154. 
Jenkins, T. C., V. Fellner, and R. K. McGuffey. 2003. Monensin by fat interactions on trans fatty acids in cultures of mixed ruminal microorganisms grown in continuous fermentors fed corn or barley. J. Dairy Sci. 86:324-330.

Kim, K. H., Y. G. Oh, J-J. Choung, and D. G. Chamberlain. 1999. Effects of varying the degree of synchrony of energy and nitrogen release in the rumen on the synthesis of microbial protein in cattle consuming grass silage. J. Sci. Food Agric. 79:833-838.

Klopfenstein, T. 1996. Need for escape protein by grazing cattle. Anim. Feed Sci. Technol. 60:191-199.

Kolver, E. S., and L. D. Muller. 1998. Performance and nutrient intake of high producing Holstein cows consuming pasture or a total mixed ration. J. Dairy Sci. 81:1403-1411.

Kolver, E. S., L. D. Muller, and G. A. Varga. 1998. Ruminal utilization of pasture nitrogen in response to inclusion of dietary starch. Proc. N.Z. Soc. Anim. Prod. 58:106-109.

Lana, R. P., J. B. Russell, and M. E. Van Amburgh. 1998. The role of $\mathrm{pH}$ in regulating ruminal methane and ammonia production. J. Anim. Sci. 76:2190-2196.

Mackle, T. R., A. M. Bryant, and C. R. Parr. 1996. Nitrogen fertilizer effects on milk yield and composition, pasture intake, nitrogen and energy partitioning, and rumen fermentation parameters of dairy cows in early lactation. N.Z. J. Agric. Res. 39:341-356.

Mertens, D. R. 1994. Regulation of forage intake. Pages 450-493 in Forage Quality, Evaluation and Utilization (Ed. G. C. Fahey, Jr.). American Society of Agronomy, Inc., Crop Science Society of America, Inc., Soil Science Society of America, Inc. Madison, WI.

Mould, F. L., E. R. Orskov, and S. O. Mann. 1984. Associative effects of mixed feeds. I. Effects of type and level of supplementation and the influence of the rumen fluid $\mathrm{pH}$ on cellulolysis in vivo and dry matter digestion of various roughages. Anim. Feed Sci. Technol. 
$10: 15-30$.

National Research Council, 2001. Nutrient Requirements of Dairy Cattle. $7^{\text {th }}$ rev. ed. Natl. Academic Press, Washington, DC.

Olubobokun, J. A., W. M. Craig, and W. A. Nipper. 1988. Characteristics of protozoal and bacterial fractions from microorganisms associated with ruminal fluid particles. J. Anim. Sci. $66: 2701-2710$.

Pitt, R. E., J. S. Van Kessel, D. G. Fox, A. N. Pell, M. C. Barry, and P. J. Van Soest. 1996. Prediction of volatile fatty acids and $\mathrm{pH}$ within the net carbohydrate and protein system. J. Anim. Sci. 74:226-244.

Reis, R. B., and D. K. Combs. 2000a. Effects of corn processing and supplemental hay on rumen environment and lactation performance of dairy cows grazing grass-legume pasture. J. Dairy Sci. 83:2529-2538.

Reis, R. B., and D. K. Combs. 2000b. Effects of increasing levels of grain supplementation on rumen environment and lactation performance of dairy cows grazing grass-legume pasture. J. Dairy Sci. 83:2888-2898.

Reis, R. B., F. San Emeterio, D. K. Combs, L. D. Satter, and H. N. Costa. 2001. Effects of corn particle size and source on performance of lactating cows fed direct-cut grass-legume forage. J. Dairy Sci. 84:429-441.

Russell, J. B., J. D. O’Connor, D. G. Fox, P. J. Van Soest, and C. J. Sniffen. 1992. A net carbohydrate and protein system for evaluating cattle diets. I. Ruminal fermentation. J. Anim. Sci. 70:3551-3561.

SAS User's Guide: Statistics, Version 9.1.3 Edition. 2002. SAS Inst., Inc. Cary, NC.

Satter, L. D., H. G. Jung, A. M. Van Vuuren, and F. M. Engels. 1999. Challenges in the 
nutrition of high-producing ruminants. Page 609 in Nutritional Ecology of Herbivores. (Eds. H. C. Jung and G. C. Fahey, Jr.). ASAS, Savoy, IL.

Satter, L. D., and L. L. Slyter. 1974. Effect of ammonia concentration on rumen microbial protein production in vitro. Br. J. Nutr. 32:199-208.

Siciliano-Jones, J., and M. R. Murphy. 1989. Production of volatile fatty acids in the rumen and cecum-colon of steers as affected by forage:concentrate and forage physical form. J. Dairy Sci. 72:485-492.

Slyter, L.L., M. P. Bryant, and M. J. Wolin. 1966. Effect of $\mathrm{pH}$ on population and fermentation in a continuously cultured rumen ecosystem. Appl. Microbiol. 14, 573-577. Soriano, F. D., C. E. Polan, and C. N. Miller. 2001. Supplementing pasture to lactating Holsteins fed a total mixed ration. J. Dairy Sci. 84:2460-2468.

Steel, R. G. D., J. H. Torrie, and D. A. Dickey. 1997. Principles and Procedures of Statistics: A Biochemical Approach ( $3^{\text {rd }}$ Ed.). McGraw-Hill Book Co., NY.

Steg, A., W. M. van Straalen, V. A. Hindle, W. A. Wensink, F. M. H. Dooper, and R. L. M. Schils. 1994. Rumen degradation and intestinal digestion of grass and clover at two maturity levels during the season in dairy cows. Grass Forage Sci. 49:378-390.

Sutton, J. D., W. H. Broster, E. Schuller, D. J. Napper, V. J. Broster, and J. A. Bines. 1988. Influence of plane of nutrition and diet composition on rumen fermentation and energy utilization by dairy cows. J. Agric. Sci. (Camb.) 110:261-270.

Tamminga, S. 1986. Utilization of naturally occurring NPN-compounds by ruminants. Arch. Anim. Nutr. 36:169-176.

Tas, B. M., H. Z. Taweel, H. J. Smit, A. Elgersma, J. Dijkstra, and S. Tamminga. 2006. Rumen degradation characteristics of perennial ryegrass cultivars during the growing season. 
Anim. Feed Sci. Tech. Article in Press.

Teather, R. M., and F. D. Sauer. 1988. A naturally compartmented rumen simulation system for the continuous culture of rumen bacteria and protozoa. J. Dairy Sci. 71:666-673.

Terry, R. A., J. M. A. Tilley, and G. E. Outen. 1969. Effect of pH on cellulose digestion under in vitro conditions. J. Sci. Food Agric. 20:317-320.

Tucker, W. B., B. J. Rude, and S. Wittayakun. 2001. Case Study: Performance and economics of dairy cows fed a corn silage-based total mixed ration or grazing annual ryegrass during mid to late lactation. Prof. Anim. Sci. 17:195-201.

Undersander, D., D. R. Mertens, and N. Thiex. 1993. Forage Analyses Procedures. National Forage Testing Association. P. O. Box 371115, Omaha, NE 68137.

Ushida, K., J. P. Jouany, and P. Thivend. 1986. Role of rumen protozoa in nitrogen digestion in sheep given two isonitrogenous diets. Br. J. Nutr. 56:407-419.

Van Soest, P. J. 1994. Nutritional Ecology of the Ruminant, $2^{\text {nd }}$ Edition. Cornell University Press, Ithaca, NY.

Van Vuuren, A. M., S. Tamminga, and R. S. Ketelaar. 1991. In sacco degradation of organic matter and crude protein of fresh grass (Lolium perenne) in the rumen of grazing dairy cows. J. Agric. Sci. (Camb.) 116:429-436.

Vibart, R. E., S. P. Washburn, V. Fellner, M. H. Poore, J. T. Green, Jr., and C. Brownie. 2007. Varying endophyte status and energy supplementation of fresh tall fescue in continuous culture. Anim. Feed Sci. Technol. 132:123-136.

White, S. L., G. A. Benson, S. P. Washburn, and J. T. Green, Jr. 2002. Milk production and economic measures in confinement or pasture systems using seasonally calved Holstein and Jersey cows. J. Dairy Sci. 85:95-104. 
Wolin, M. J. 1960. A theoretical rumen fermentation balance. J. Dairy Sci. 43:1452-1459. 
Table 1. Ingredients of the total mixed ration (TMR) added to the continuous culture vessels.

\begin{tabular}{lc}
\hline Ingredient composition $^{\mathbf{1}}$ & \% (DM basis) \\
\hline Corn silage & 26.9 \\
Alfalfa silage & 13.0 \\
Whole cottonseed & 18.0 \\
Soybean hulls & 9.1 \\
Corn gluten feed & 8.9 \\
Bypass blend & \\
Corn grain, ground & 4.4 \\
48\% SBM & \\
Calcitic limestone & 15.9 \\
Salt & 1.2 \\
Sodium bicarbonate & 0.55 \\
Bentonite & 0.43 \\
Vitamin TM premix & 0.75 \\
Potassium carbonate & 0.65 \\
\hline
\end{tabular}

${ }^{1}$ Mineral composition, DM basis: $0.77 \% \mathrm{Ca} ; 0.45 \% \mathrm{P} ; 0.24 \% \mathrm{Mg} ; 1.09 \% \mathrm{~K} ; 0.24 \% \mathrm{~S}$;

0.38\% Na; 19 ppm Cu; 374 ppm Fe; 67 ppm Mn; 87 ppm Zn (NCDA Forage Lab).

${ }^{2}$ Blend of poultry by-product meal, hydrolyzed poultry feathers, meat and bone meal, blood meal, and fish meal (Nutrimax Inc., Greensboro, NC).

${ }^{3}$ Soybean meal.

${ }^{4}$ Volclay ${ }^{\circledR}$ (American colloid Co., Arlington Heights, IL). 
Table 2. Chemical composition (mean $\pm \mathrm{SE}$ ) of the total mixed ration (TMR) and forage added to the continuous culture vessels.

\begin{tabular}{|c|c|c|}
\hline Constituent & TMR & Forage" \\
\hline DM, \% & $50.8 \pm 0.6$ & $25.2 \pm 0.9$ \\
\hline $\mathrm{OM}, \%$ of $\mathrm{DM}$ & $93.2 \pm 0.2$ & $92.8 \pm 0.1$ \\
\hline $\mathrm{NDF}, \%$ of $\mathrm{DM}$ & $44.3 \pm 0.6$ & $44.7 \pm 0.8$ \\
\hline $\mathrm{ADF}, \%$ of $\mathrm{DM}$ & $22.2 \pm 0.8$ & $21.3 \pm 0.4$ \\
\hline $\mathrm{CP}, \%$ of $\mathrm{DM}$ & $15.9 \pm 0.3$ & $13.8 \pm 0.6$ \\
\hline \multicolumn{3}{|c|}{ Protein fractions, $\%$ of $\mathrm{CP}$} \\
\hline$A^{1}$ & 26.4 & 11.0 \\
\hline $\mathrm{B}_{1}{ }^{2}$ & 3.0 & 37.9 \\
\hline $\mathrm{B}_{2}^{3}$ & 65.0 & 45.3 \\
\hline $\mathrm{B}_{3}{ }^{4}$ & 2.9 & 4.7 \\
\hline$C^{5}$ & 2.7 & 1.0 \\
\hline IVTDMD, $\%$ of $\mathrm{DM}^{6}$ & $79.6 \pm 1.5$ & $93.1 \pm 0.5$ \\
\hline $\mathrm{NE}_{1}, \mathrm{Mcal} / \mathrm{kg} \mathrm{DM}^{\prime}$ & 1.60 & 1.80 \\
\hline \multicolumn{3}{|c|}{$\begin{array}{l}\text { *Mineral composition, DM basis: } 0.46 \% \mathrm{Ca} ; 0.40 \% \mathrm{P} ; 0.24 \% \mathrm{Mg} ; 3.58 \% \mathrm{~K} ; 0.30 \% \mathrm{~S} \text {; } \\
0.05 \% \mathrm{Na} ; 7 \mathrm{ppm} \mathrm{Cu} ; 88 \mathrm{ppm} \mathrm{Fe} ; 17 \mathrm{ppm} \mathrm{Mn} ; 27 \mathrm{ppm} \mathrm{Zn} \text { (NCDA Forage Lab). } \\
{ }^{1} \text { Non-protein N. }{ }^{2} \text { Borate-soluble protein. }{ }^{3} \text { Insoluble protein - neutral detergent insoluble } \\
\text { protein (NDIP). }{ }^{4} \mathrm{NDIP} \text { - acid detergent insoluble protein (ADIP). }{ }^{5} \mathrm{ADIP} . \\
{ }^{6} \text { In vitro true DM disannearance. }\end{array}$} \\
\hline $\mathrm{NE}_{1}$ of forage $=(1.087$ & $\mathrm{F} \%)) \times 2.2($ & 1993). \\
\hline
\end{tabular}


Table 3. Forage/concentrate ratios and chemical composition of the diets added to the continuous culture vessels.

\begin{tabular}{lcccc}
\hline \multirow{2}{*}{ Constituent } & \multicolumn{4}{c}{ Treatments $^{\mathbf{1}}$} \\
\cline { 2 - 5 } F:C & $\mathbf{5 5 T}$ & $\mathbf{7 0 T}$ & $\mathbf{8 5 T}$ & $\mathbf{1 0 0 T}$ \\
OM, \% of DM & $67: 33$ & $58: 42$ & $49: 51$ & $40: 60$ \\
NDF, \% of DM & 93.0 & 93.1 & 93.1 & 93.2 \\
ADF, \% of DM & 44.5 & 44.4 & 44.4 & 44.3 \\
CP, \% of DM & 21.8 & 21.9 & 22.1 & 22.2 \\
IVTDMD, \% of DM & 15.0 & 15.3 & 15.6 & 15.9 \\
NE $_{1}$, Mcal/kg DM & 85.7 & 83.7 & 81.6 & 79.6 \\
\hline
\end{tabular}

${ }^{1} 55 \mathrm{~T}=55 \% \mathrm{TMR}+45 \%$ forage, $70 \mathrm{~T}=70 \% \mathrm{TMR}+30 \%$ forage, $85 \mathrm{~T}=85 \% \mathrm{TMR}+15 \%$ forage, $100 \mathrm{~T}=100 \% \mathrm{TMR}$.

${ }^{2}$ Forage/concentrate ratio

${ }^{3}$ In vitro true DM disappearance.

${ }^{4} \mathrm{NE}_{1}$ of TMR was estimated using values of NRC (2001);

$\mathrm{NE}_{1}$ of forage $=(1.0876-(0.0127 \times \mathrm{ADF} \%)) \times 2.2$ (Undersander et al., 1993). 
Table 4. Concentration and production of VFA in continuous cultures receiving varying amounts of TMR and forage

\begin{tabular}{|c|c|c|c|c|c|c|}
\hline \multirow[b]{2}{*}{ Variable $^{3}$} & \multicolumn{4}{|c|}{ Treatments $^{1}$} & \multirow[b]{2}{*}{ SEM } & \multirow{2}{*}{$\frac{P \leq}{t}$} \\
\hline & $55 \mathrm{~T}$ & 70T & $85 T$ & $100 \mathrm{~T}$ & & \\
\hline Total, $\mathbf{m} M$ & $64.5^{\mathrm{e}}$ & $55.7^{f}$ & $58.9^{\mathrm{ef}}$ & $51.1^{\mathrm{f}}$ & 5.5 & 0.08 \\
\hline \multicolumn{7}{|c|}{ Individual, mol/100 mol } \\
\hline Acetate $(\mathrm{A})$ & $40.9^{\mathrm{a}}$ & $39.6^{\mathrm{a}}$ & $44.6^{\mathrm{b}}$ & $47.9^{\mathrm{c}}$ & 1.8 & 0.001 \\
\hline Propionate $(\mathrm{P})$ & $20.3^{\mathrm{a}}$ & $20.2^{\mathrm{a}}$ & $24.7^{\mathrm{b}}$ & $27.2^{\mathrm{b}}$ & 1.6 & 0.001 \\
\hline Butyrate & $27.0^{\mathrm{a}}$ & $27.4^{\mathrm{a}}$ & $20.7^{b}$ & $16.1^{\mathrm{c}}$ & 2.1 & 0.001 \\
\hline Isobutyrate & $0.8^{\mathrm{a}}$ & $0.9^{\mathrm{ab}}$ & $0.9^{b c}$ & $1.0^{\mathrm{c}}$ & 0.07 & 0.001 \\
\hline Valerate & $7.3^{\mathrm{a}}$ & $7.4^{\mathrm{a}}$ & $4.4^{\mathrm{b}}$ & $2.6^{\mathrm{c}}$ & 0.9 & 0.001 \\
\hline Isovalerate & $3.7^{\mathrm{a}}$ & $4.5^{\mathrm{b}}$ & $4.8^{\mathrm{bc}}$ & $5.3^{c}$ & 0.2 & 0.001 \\
\hline \multicolumn{7}{|c|}{ Individual, $\mathrm{mmol} / \mathrm{d}$} \\
\hline Acetate & $43.7^{\mathrm{e}}$ & $36.6^{f}$ & $43.8^{\mathrm{e}}$ & $41.1^{\mathrm{ef}}$ & 3.5 & 0.08 \\
\hline Propionate & $21.2^{\mathrm{a}}$ & $18.1^{\mathrm{b}}$ & $23.9^{\mathrm{a}}$ & $23.3^{\mathrm{a}}$ & 1.5 & 0.001 \\
\hline Butyrate & $30.2^{\mathrm{a}}$ & $26.4^{\mathrm{ab}}$ & $20.9^{b c}$ & $13.7^{\mathrm{c}}$ & 4.2 & 0.002 \\
\hline Isobutyrate & 0.8 & 0.8 & 0.9 & 0.8 & 0.1 & 0.59 \\
\hline Valerate & $8.2^{\mathrm{a}}$ & $7.1^{\mathrm{ab}}$ & $4.5^{\mathrm{bc}}$ & $2.2^{\mathrm{c}}$ & 1.4 & 0.001 \\
\hline Isovalerate & 4.0 & 4.2 & 4.7 & 4.5 & 0.5 & 0.27 \\
\hline Total, $\mathrm{mmol} / \mathrm{d}$ & $108.0^{\mathrm{e}}$ & $93.3^{f}$ & $98.7^{\mathrm{ef}}$ & $85.5^{\mathrm{f}}$ & 9.2 & 0.08 \\
\hline$A: P$ ratio & $2.11^{\mathrm{a}}$ & $2.03^{\mathrm{ab}}$ & $1.84^{\mathrm{bc}}$ & $1.78^{\mathrm{c}}$ & 0.14 & 0.006 \\
\hline
\end{tabular}

${ }^{1} 55 \mathrm{~T}=55 \% \mathrm{TMR}+45 \%$ forage, $70 \mathrm{~T}=70 \% \mathrm{TMR}+30 \%$ forage,

$85 \mathrm{~T}=85 \% \mathrm{TMR}+15 \%$ forage, $100 \mathrm{~T}=100 \% \mathrm{TMR}$.

${ }^{2} \mathrm{t}=$ treatment.

${ }^{3}$ Each value is the mean of 4 runs.

${ }^{a, b, c}$ Least squares means in the same row with different superscripts $\operatorname{differ}(P \leq 0.05)$.

${ }^{\mathrm{e}, \mathrm{f}}$ Least squares means in the same row with different superscripts differ $(P \leq 0.10)$. 
Table 5. Ruminal pH, ammonia-N $\left(\mathrm{NH}_{3}-\mathrm{N}\right)$, and methane $\left(\mathrm{CH}_{4}\right)$ production in continuous cultures receiving varying amounts of TMR and forage.

\begin{tabular}{|c|c|c|c|c|c|c|}
\hline \multirow[b]{2}{*}{ Variable $^{3}$} & \multicolumn{4}{|c|}{ Treatments $^{1}$} & \multirow[b]{2}{*}{ SEM } & \multirow{2}{*}{$\frac{P \leq^{2}}{t}$} \\
\hline & $55 \mathrm{~T}$ & $70 \mathrm{~T}$ & $85 T$ & $100 \mathrm{~T}$ & & \\
\hline Culture pH & $5.80^{\mathrm{e}}$ & $5.65^{\mathrm{f}}$ & $5.78^{\mathrm{ef}}$ & $5.68^{\mathrm{f}}$ & 0.08 & 0.06 \\
\hline $\mathrm{NH}_{3}-\mathrm{N}, \mathrm{mg} / \mathrm{dl}$ & 23.2 & 22.9 & 23.1 & 23.3 & 0.9 & 0.98 \\
\hline $\mathrm{NH}_{3}-\mathrm{N}, \mathrm{g} / \mathrm{d}$ & 0.39 & 0.38 & 0.39 & 0.39 & 0.02 & 0.98 \\
\hline $\mathrm{CH}_{4}, \mathrm{mmol} / \mathrm{d}$ & $26.1^{\mathrm{a}}$ & $16.6^{\mathrm{b}}$ & $35.5^{\mathrm{c}}$ & $42.5^{\mathrm{d}}$ & 2.9 & 0.001 \\
\hline $\mathrm{CH}_{4}, \mathrm{mmol} / \mathrm{g} \mathrm{DM}$ fed & $1.3^{\mathrm{a}}$ & $0.8^{\mathrm{b}}$ & $1.8^{\mathrm{c}}$ & $2.1^{\mathrm{d}}$ & 0.1 & 0.001 \\
\hline $\operatorname{Gas}^{4}, \mathbf{m m o l} / \mathbf{d}$ & 206.5 & 172.3 & 193.5 & 175.0 & 16.3 & 0.11 \\
\hline
\end{tabular}

${ }^{1} 55 \mathrm{~T}=55 \% \mathrm{TMR}+45 \%$ forage, $70 \mathrm{~T}=70 \% \mathrm{TMR}+30 \%$ forage, $85 \mathrm{~T}=85 \% \mathrm{TMR}+15 \%$ forage, $100 \mathrm{~T}=100 \% \mathrm{TMR}$.

${ }^{2} \mathrm{t}=$ treatment.

${ }^{3}$ Each value is the mean of 4 runs.

${ }^{4}$ Fermentative $\mathrm{CH}_{4}+$ fermentative $\mathrm{CO}_{2}(\mathrm{c})+$ buffering $\mathrm{CO}_{2}(\mathrm{c})$; (c) = calculated

a, b, c, d Least squares means in the same row with different superscripts differ $(P \leq 0.05)$.

${ }^{\mathrm{e}, \mathrm{f}}$ Least squares means in the same row with different superscripts differ $(P \leq 0.10)$. 
Table 6. Substrate partition, fermentability, microbial $\mathbf{N}$ flow, and microbial efficiency in continuous cultures receiving varying amounts of TMR and forage.

\begin{tabular}{|c|c|c|c|c|c|c|}
\hline \multirow[b]{2}{*}{ Variable $^{3}$} & \multicolumn{4}{|c|}{ Treatments $^{1}$} & \multirow[b]{2}{*}{ SEM } & \multirow{2}{*}{$\frac{P \leq^{2}}{t}$} \\
\hline & $55 \mathrm{~T}$ & 70T & $85 T$ & $100 \mathrm{~T}$ & & \\
\hline DM fed, g/d & 20.0 & 20.0 & 20.0 & 20.0 & & \\
\hline \multicolumn{7}{|l|}{ Substrate used } \\
\hline VFA, g/d & $6.4^{\mathrm{a}}$ & $5.5^{\mathrm{bc}}$ & $6.2^{\mathrm{ab}}$ & $5.4^{\mathrm{c}}$ & 0.4 & 0.02 \\
\hline $\mathrm{Gas}^{4}, \mathrm{~g} / \mathrm{d}$ & $4.5^{\mathrm{a}}$ & $3.6^{\mathrm{b}}$ & $4.5^{\mathrm{a}}$ & $4.3^{\mathrm{a}}$ & 0.3 & 0.04 \\
\hline Microbial cells ${ }^{5}, \mathrm{~g} / \mathrm{d}$ & $1.98^{\mathrm{a}}$ & $1.65^{b}$ & $1.23^{\mathrm{c}}$ & $0.85^{\mathrm{d}}$ & 0.08 & 0.001 \\
\hline Total & $12.8^{\mathrm{a}}$ & $10.5^{\mathrm{b}}$ & $11.9^{\mathrm{a}}$ & $10.5^{\mathrm{b}}$ & 0.7 & 0.002 \\
\hline Fermentation $^{6}, \%$ & $53.8^{\mathrm{a}}$ & $44.3^{b}$ & $53.5^{\mathrm{a}}$ & $48.4^{\mathrm{ab}}$ & 3.4 & 0.01 \\
\hline Fermentation $^{7}, \%$ & $63.8^{\mathrm{a}}$ & $52.6^{\mathrm{b}}$ & $59.7^{\mathrm{a}}$ & $52.6^{\mathrm{b}}$ & 3.5 & 0.002 \\
\hline \multicolumn{7}{|l|}{ Microbial N } \\
\hline$\%$ of microbial cells & $7.27^{\mathrm{ef}}$ & $7.65^{\mathrm{f}}$ & $7.35^{\mathrm{f}}$ & $6.82^{\mathrm{e}}$ & 0.18 & 0.06 \\
\hline Flow, g/d & $0.16^{\mathrm{a}}$ & $0.14^{\mathrm{a}}$ & $0.10^{\mathrm{b}}$ & $0.07^{\mathrm{c}}$ & 0.009 & 0.001 \\
\hline \multicolumn{7}{|l|}{ Efficiency } \\
\hline Microbial DM, g/kg OM ${ }^{8}$ & $107.0^{\mathrm{a}}$ & $88.9^{\mathrm{b}}$ & $66.4^{\mathrm{c}}$ & $45.5^{\mathrm{d}}$ & 6.2 & 0.001 \\
\hline Microbial DM, g/kg OM ${ }_{\mathrm{tf}}{ }^{9}$ & $147.6^{\mathrm{a}}$ & $150.6^{\mathrm{a}}$ & $105.0^{\mathrm{b}}$ & $80.9^{\mathrm{b}}$ & 12.3 & 0.002 \\
\hline
\end{tabular}

${ }^{1} 55 \mathrm{~T}=55 \% \mathrm{TMR}+45 \%$ forage, $70 \mathrm{~T}=70 \% \mathrm{TMR}+30 \%$ forage, $85 \mathrm{~T}=85 \% \mathrm{TMR}+15 \%$ forage, $100 \mathrm{~T}=100 \% \mathrm{TMR}$.

${ }^{2} \mathrm{t}=$ treatment. ${ }^{3}$ Each value is the mean of 4 runs.

${ }^{4} \mathrm{Gas}, \mathrm{g} / \mathrm{d}=\left(\mathrm{CO}_{2}, \mathrm{~mol} / \mathrm{d} \mathrm{x} \mathrm{44}\right)+\left(\mathrm{CH}_{4}, \mathrm{~mol} / \mathrm{d} \times 16\right)+\left(\mathrm{H}_{2} \mathrm{O}, \mathrm{mol} / \mathrm{d} \times 36\right)$

${ }^{5}$ Measured.

${ }^{6}$ Apparent: substrate used for VFA and gas production as a \% of DM fed.

${ }^{7}$ True: substrate used for VFA, gas, and microbial biomass synthesis as a \% of DM fed.

${ }^{8}$ Microbial DM per kg of OM fed.

${ }^{9}$ Microbial DM per kg of OM truly fermented.

a, b, c, d Least squares means in the same row with different superscripts differ $(P \leq 0.05)$.

e, $\mathrm{f}$ Least squares means in the same row with different superscripts differ $(\mathrm{P} \leq 0.10)$. 


\section{CHAPTER 5}

\section{OVERALL CONCLUSIONS}

Two field studies and an in vitro continuous culture study were conducted to evaluate the use of feeding systems that combine pasture and TMR. For the field trials, I hypothesized that 1) cows consuming a diet including some TMR-to-pasture combination would perform as well as, or even outperform, an all-confinement diet, as opposed to a decrease in animal performance as TMR-restricted diets incorporated increasing levels of pasture; and 2) the level of pasture intake threshold in terms of significant losses in lactation performance would fall within the TMR-pasture combinations tested. Also, for the continuous culture study, I hypothesized that a nutritionally balanced TMR would maximize post-ruminal nutrient and protein supply, but proportional microbial protein supply would be increased by increasing the proportions of high-quality forage in the diets.

After summarizing both field trials, it was demonstrated that cows fed diets that had decreased TMR proportions to $52 \%$ of initial average herd intakes (100\% TMR was set at $23.9 \mathrm{~kg} / \mathrm{d}$ in the fall of 2004 and $23.3 \mathrm{~kg} / \mathrm{d}$ in the spring of 2005) were highly competitive compared to 100T. Because of unrestricted offering, actual TMR intakes of $100 \mathrm{~T}$ increased to 25.8 and $24.9 \mathrm{~kg} / \mathrm{d}$ in F2004 and S2005, respectively. Milk and 4\% FCM yields from feeding 55T vs. $100 \mathrm{~T}$ were not different in F2004 $(1.2$ and $0.0 \mathrm{~kg} / \mathrm{d}$ of milk and FCM, respectively, greater for 100T); and were greater $(P<0.05)$ for 100T vs. 55T in S2005 (3.9 and $2.0 \mathrm{~kg} / \mathrm{d}$ of milk and FCM, respectively). These differences, reported to be significant in S2005, raise a number of new questions that may guide future applied research: Do the differences in performance 'bridge' the differences in feeding costs and lifestyle? Do the differences in performance justify handling the increased amount of manure and urine 
nutrients that are heavily concentrated in pre-determined areas instead of spread naturally in the grazing fields? And, though seemingly extreme, who would you rather have as a neighbor?

Also, my initial reasoning was that cows would abstain some from consuming TMR and would increase pasture intake, at least to greater levels that what was reported. I wonder if previous experience (i.e. previous access to pasture other than dry-lot access to native pastures) would have enhanced pasture intake above what was seen. Because dietary treatments tested in previous studies have attempted to cover a broad range of dairy feeding systems (i.e. a whole feeding systems approach including pasture-alone or pasture-based diets vs. TMR diets), increasing the amount of pasture would most expectedly reduce lactation performance. A limited amount of research has focused on finding optimal combinations of both systems. Dairy producers that have been feeding confinement-type diets in the past and are willing to transition to pasture-based systems (organic or nonorganic pastoral dairying) are equipped with facilities and machinery to make the best use possible of supplementation (conserved forages and concentrates).

In summary, hypothesis 1 was supported by the results, but hypothesis 2 may require further research in terms of expanding some the amounts of high-quality pasture fed relative to amounts of TMR. Indeed, increasing the amount of forage fed to continuous cultures resulted in an increase $(P<0.05)$ in microbial biomass and microbial DM flow to the lower tract. 